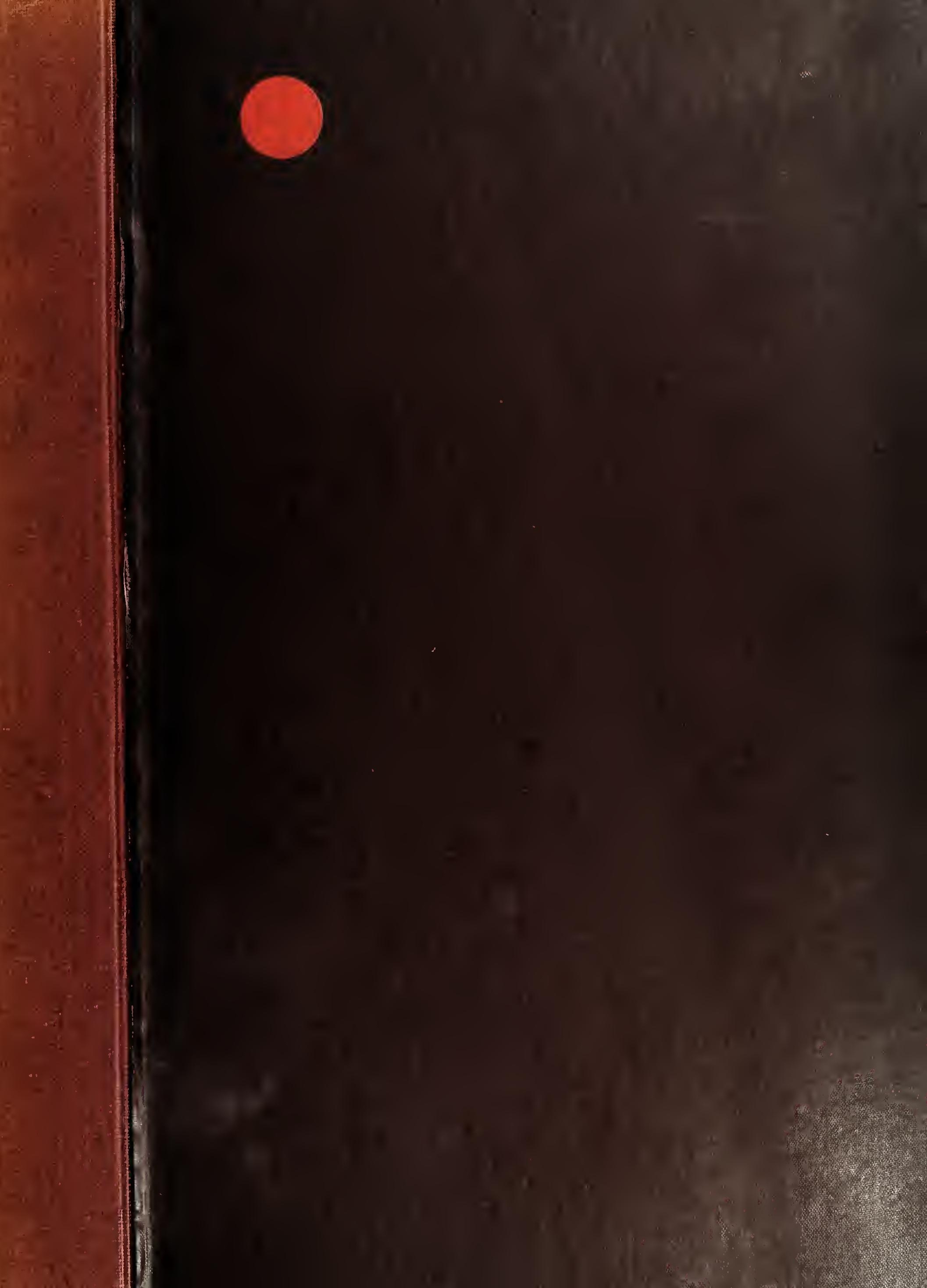




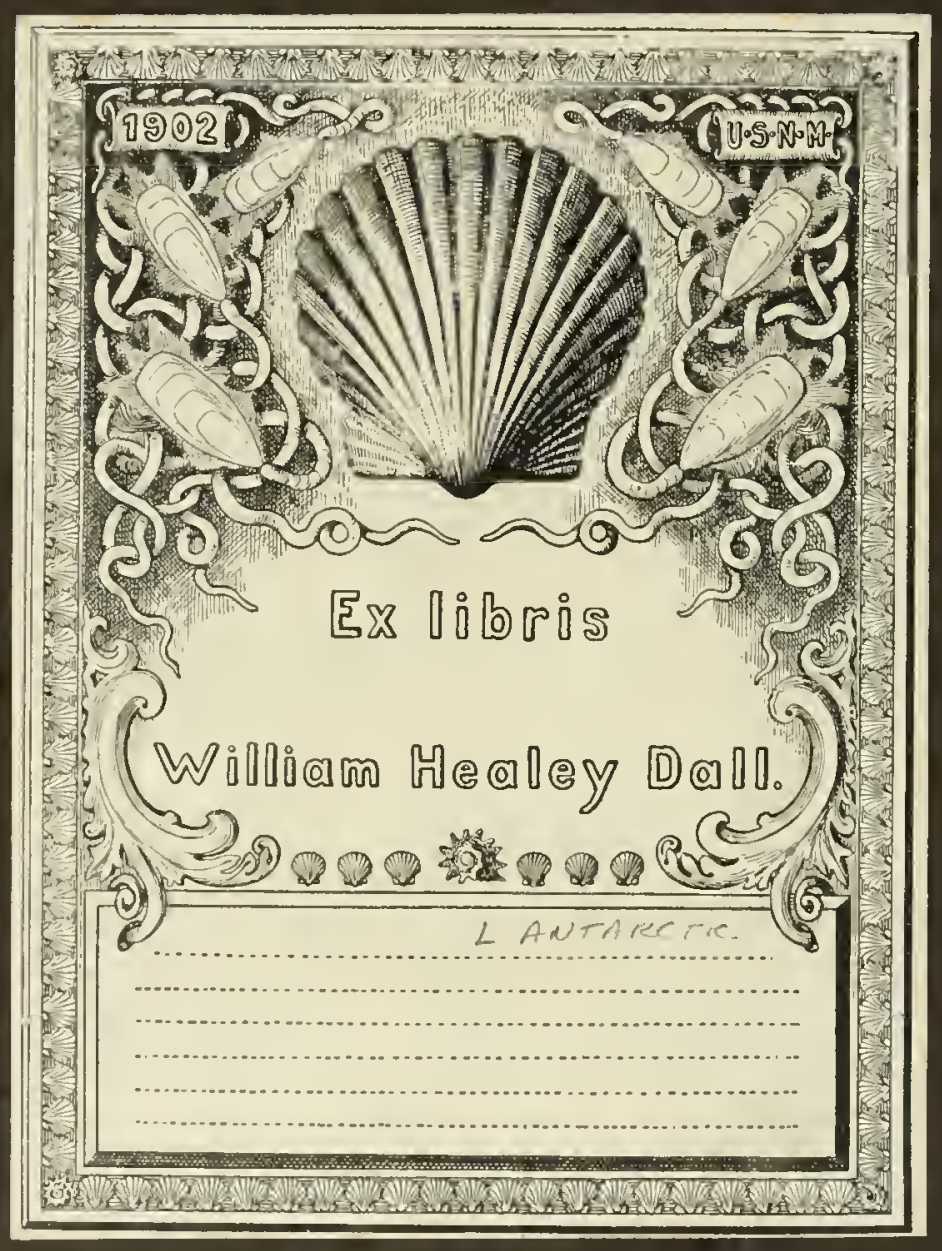




Division of Morlibeles

Secticanal Iishors 

ron

NATIONAL ANTARCTIC EXPEDITION

Moll.

1901-1904

NATURAL HISTORY

198812

\author{
VOL. I. \\ GEOLOG Y \\ (FIELD-GEOLOGY : PETROGRAPHY)
}

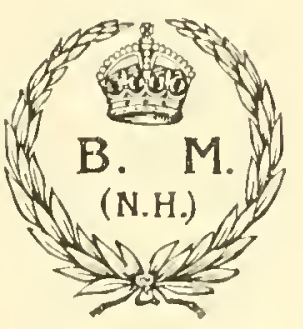

LONDON :

PRINTED BY ORDER OF THE, TRUSTFES OF

THE, BRITISH MUSEUM.

1907

(All Rights Reserved)

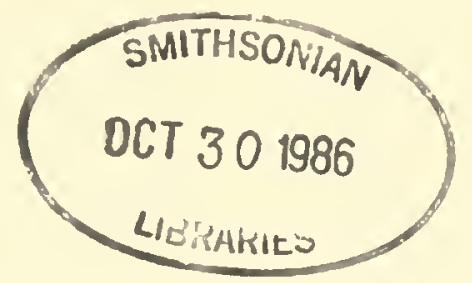


Sold by Longmans and Co., 39 I'Aternoster Row, E.C.; Bernard Quaritch, I5 Piccadlly, It.; I)UtAU ANij Co., 37 Sollo SeUare, W.;

$\triangle N D$ A

Tile Beitisis Museum (Natural mistory), Cronivel. Koad, London, S. W. 


\section{PREFACE.}

When, in 1901, the Expedition of the S.S. 'Discovery,' under Captain Scott, R.N., was sent to the Antaretic Regions, the Trustees of the British Museum gave their assistance to this national enterprise by allowing the eases containing the natural listory specimens which might be obtained liy the Expedition to be sent to the Natural History Museum for unpacking and sorting. They further undertook to publish a detailed report on the collections so obtained, under the superintendence of the Director of the Natural Fistory Departments.

Some of the most important colleetions have heen dealt with by naturalists who were nembers of the Expedition. 'Thus, the Mammals and Birds are described by Dr. Edward A. Wilson, the Isopoda and Pyenogonida by M.r. T. V. Ilougson, and the Rocks (in relation to Field Geology) by Mr. II. T. Ferrar. Other groups lave been dealt with by members of the staff of the Natural History Departments of the British Museum: Mr. Bonlenger deseribes the Fishes; Mr. E. A. Smith, the Gastropoda, Lamellibranehia, and Brachiopoda; Mr. Jeftrey Bell, the Echinoderma; Dr. Calman, the Crustacea Decapoda, and the Cumacea; Mr. Kirkpatrick, the noncalcareous Sponges; whilst Dr. G. T. Prior has prepared a petrographical description of the Rock-specimens.

It has been necessary to obtain the assistance of other specialists in order to deal with the rest of the eollections. So far as the latter group of contrilutors is concerned, the following is a list of the subject-matters, together with the name of the naturalist who has undertaken the work in each case :-

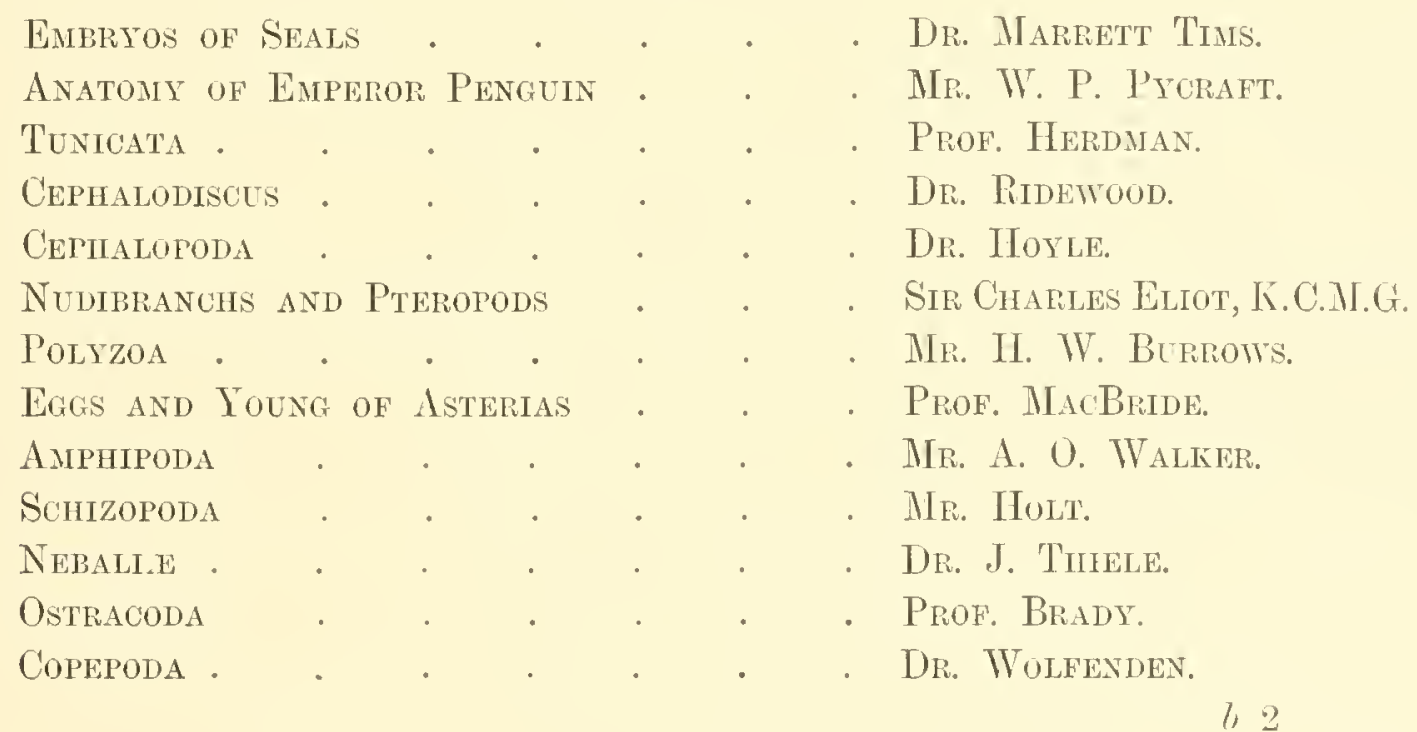




\begin{tabular}{|c|c|c|c|c|}
\hline Crimiredia & . & . & · & . Prof. Gruver. \\
\hline MY"\%OTONA & . & . & . & - Prof. v. Grafe. \\
\hline AC:AIII & . & . & . & - Dr. Trouessart. \\
\hline CoLlenisola & . & . & . & - Prof. Carpenter. \\
\hline PoLYCI LTA & . & . & . & - Prof. Ehlers. \\
\hline Gephyria & . & . & . & - Mr. A. Е. SHIPley. \\
\hline CH.TTOGATHA & . & . & . & . Dr. Fowler. \\
\hline Neniertixes & . & . & . & . Prof. Hubrecht. \\
\hline Free Platyield & MNTHF & $\mathrm{ES}$ & . & - Mr. F. F. LaidLaw. \\
\hline ('ESTODA . & . & . & . & . Mr. A. E. SHIPLEY. \\
\hline Nenatuda & . & . & . & . DR. V. Linstow. \\
\hline ZOANTHARIA & . & . & · & - Mr. Cludis. \\
\hline LLTONARIA ANI & PEN & NATULIIA & . & . Prof. IItchison. \\
\hline HYTRUNEDUSA & . & . & . & - Mr. E. 'T. Brown. \\
\hline Calcareous Spo & $\mathrm{NGES}$ & . & . & - Mr. Frewen Jenkin. \\
\hline Riadolaria & . & - & . & . Mr. Lewis H. Goegh. \\
\hline MOSSES & . & . & . & - M. Jules Cardot. \\
\hline LICHEXS . & . & . & . & . Mr. Darbishire. \\
\hline MLitis (Mafine) & & . & . & . Mrs. GePP. \\
\hline ALGE (FRESII-W & ATER) & . & . & . Dr. Fritscil. \\
\hline AlGA (CALCAREC & ous) & . & . & Dr. Foslie. \\
\hline PIITOPLANKTON & & . & . & . Dr. Lewis H. Gough. \\
\hline
\end{tabular}

The work of securing the assistance of these specialists and of distributing the collections has been performed by Mr. Jeffrey Bell, of the Zoologieal Department, who las also aeted as sub-editor of the Zoologieal and Botanieal portions of the reports. The Keeper of Minerals, Mr. Fletcher, has superintended the reports in the suhjects helonging to his tepartment.

The Dircetor desires to acknowledge the ability and energy which have been hrought to hear on the preparation of the Zoological reports by Mr. Ieffrey Bell. Uwing to his care, the reports have been got ready by the rarious contributors and pullisher within a reasonable time after the return of the 'Discovery' from the Intarctic liegions. Neither trouble nor expense has been spared in order to render the illustration and presentation of the Natural History of the Expedition worthy of the generous efforts both of Captain Scott and his fellow-explorers and of those who provided the funds for that enterprise.

L. Ray Laykester. 


\section{PREFACE T() VOLUME I.}

Tue mineral-specimens collected during the 'Discovery' Antarctic Expedition being virtnally all of them rock-specimens, their importance depends, not merely on their own characters, but on the mutual relations of the masses which they represent; in these circumstances, a Report deseriptive of the sperimens thenselves an be of little scientifie value unless preceded by an acrount of the rock-masses of which they have formed part.

Mr. II. T. Ferrar, Geologist to the Expedition, harl lived in the region and collected nearly all the specimens, and was obviously the one to be invited to prepare a monograph of the Fiekl-geology. Fortunately he was ahle to arept the invitation, and to subnit the manuseript of his lieport before lenving England to take up an appointment on the Geological Survey of Egypt.

The scientifie description of the specimens was entrusterl to Dr. G. 'T. Prior, dssistant in the Mineral lepartment, who had alrearly examined and describer the mineral-specimens collected during the 'Poss' and the 'Southern C'russ' Antarctic Expeditions.

The points regarded by the author's as deserving special attention are conveniently indieated in the respective Summaries (pp. 98, 139).

The elaborate Index to the volume has been made hy Dr. Prior.

It has been my duty, as Keeper of the Mineral Department, to supervise the preparation and publication of these Reports, but the seientific part of the work has been done entirely by the respective authors.

\section{Fletcher.}

Minerat Departifent,

British Museum (Natural History),

May 1, 1907. 



\section{TABLE OF CONTENTS.}

\section{I.-REPORT ON THE FIELD-GEOLOGY OF THE REGION EXPLORED DURING TIIE 'DISCOTERY' ANTARCTIC EXPEDITION, 1901-4. \\ By H. T. Ferrar, M.A., F.G.S., Geologist to the Exyedition.}

CHAPTER

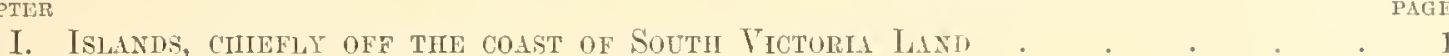

II. Time lioss Archipetago . . . . o o

III. The Mlangand of Soutil Tictoria Land . . . . . . . . . 17

IV. Tile Ganeissic Rochs and Cristalline Limestone . . . . . . . 25

V. Tme Gravites . . . . . . . . 32

VI. The Beacon sandostone formation . . . . . . . . . . 39

Appendx to Chapter YI.-Report on the Plaxt-remliss frou the Belcox

Sandstoxe. By E. A. Newell Arber, M.A., F.L.S., F.G.'. . . . . 48

VII. The Dolertites . . . . . . . . . . . . . 49

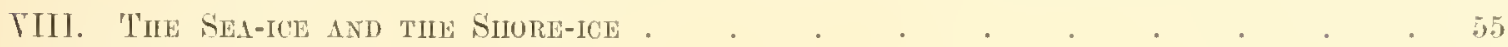

IX. The LAND-ICE . . . . . . . . . . . . . 63

X. The Land-ICe-continued . . . . . . . . . . . . . . . . . . 76

XI. Denudation.$\quad$.

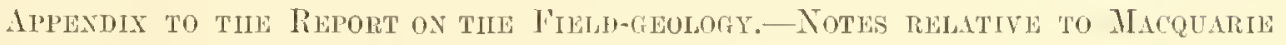
axd Auchland Islants, octsine the Antarctic Circlie . . . . 95

Sumary. . . . . . . 98

II.-REPORT ON TIIE ROCTESPECIIENA COLLECTED DURINA THE 'JISCO TERY' ANTARCTIO EXPEDTTION, 1901-t.

By G. T. Prion, M.A., D.Sc., F.G.S., Assistant in the Mineral Department, British Mnscum. INTRODUCTORY CHAPTER

I. Yolcasir Rockis . . . . . . . . . . . 102 BASALTS . . . . . . . . . . . . 102 LEENYTES . . . . . . . . . . . . . 110 Phonolitic Trachytes and Phoxolites . . . . . . . . 113 Chemical Rielations of the Yolchalo Rociss . . . . . . 119

II. The Basement-rocks of Soutif Victoria Lind . . . . . . . . 124 Cristalline Linestone han Gneiss . . . . . . . . . 124 Granites and Diorites . . . . . . . . . . . 125

III. Dyke-Rocks (Lanprophytes, Ttc.) . . . . . . . . . . . . . 129 CANiptonites . . . . . . . . . . . . 129 Kersantites . . . . . . . . . . . . . . 130 BiNAKITES . . . . . . . . . 131

IV. The Beacon Sandstone and other Sednientary Rocks . . . . . 134

. The Dolirites . . . . . . . . . . . 136 Sumuary 



\section{ILLUSTRATIONS IN THE TEXT.}

Fig. 1.-Sturge Island, Ballexi Islanis, showing transition fron "Pifonont-aground" Page

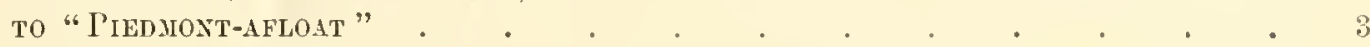

Fig. 2.- Two of tie Possession Islands. The taller one shows the junction of two TYPES OF ROCK

Fig. 3.-East side of Cotliax Island, showhg the horizontal structure of the Rocks, aNd the "Piedmont-dGround" Which surrounds the island . • • 5

Fig. 4.-Castle Rock and Moust Erebus . . . . . . . . . . . . 9

Fig. 5.-Cape Crozier and Molnt Terror . . . . . . . . . . . . 10

Fig. 6.-Cape Abare Peningula, fron Ross Sea . . . . . . . . . 17

Fig. 7.-A volchic cone ox the mainland: the sumitit of Cape Jones. The "Discovery" in a gulf in the Lady Newnes "Piediont-aflodt" • . . 19

Fig. 8.-Mount Nansen, the tabular mountain south of Cape Washingtox . . 21

Fig. 9.-Mount Huggins and the Rofal Societr Range . . . . . . . 23

Fịg. 10.-Kímg Edward VII Laxd . . . . . . . . . . . . . . 24

Fig. 11.--The crystallixe limestone ox the hill J $J_{1}$, south side of the Blue Glacier . 26

Fig. 12.- The crystaline liniestone on the nortil side of the Blue Glacier at $\mathrm{G}_{4} \cdot 27$

Fig. 13.-The gNeiss at the east exd of the Lower hÜhri Hilis, Nedr the hill H 28

Fig. 14.-Lookixg up the Ferrar Glacier, Northers Foothills ox the left, Cathedral Rochs NeAR the CENTRE, AND THE KUKRI Hills ox THE RIGHT • • • . 29

Fig. 15.-Dolerite upon firanite ox the vorth side of Granite Harbour * . $\quad 32$

Fig. 16.-Hollowed granite-Bollder ix the Sxow Valley xear the fordL Societr Rajge 34

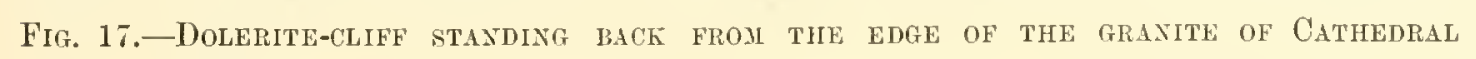
Rocks . . . . . . . . . . . . . . . . . . . . 35

Eig. 18.-The horizontal upper surface of the granite oN the south side of The

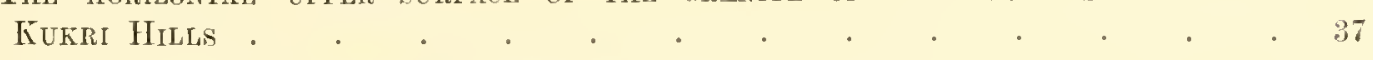

Fig. 19.-Dolerite-sill in the Beacon Sandstoxe near Finger Mountain • • $\quad 40$

Fig. 20.-The Ixland Forts. Sandstone capped bi dolerite • • • • . . 42

Fig. 21.-Impression in sandstone at West Grois. Copy of sketchi made in the field . 43

Fig. 22.--Finger Motntaix. Wedge of sandstone in the dolerite. . . . . 45

Fig. 23.-Terra Cotta Mountains, showigl dikes of dolerite • • • . . 47

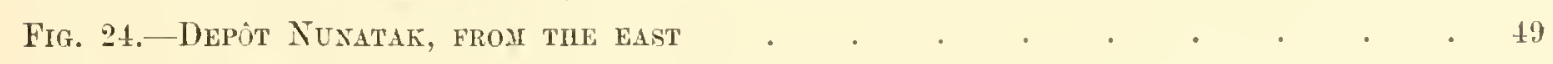

Fig. 25.-Coluinar dolerite of Depôt Nunatak . . . . . . . . . . 50

Fig. 26.-Coldyar dolerite at the foot of Knob Head. The large boulder on the SEX-LINE IS OF GRANITE . . . . . . . . . . . . . . . 52

Fig. 27.-The DARK BAND IN THE KUURI Hills ox the Right show's the dolerite-sheEt RESTING UPON THE EVEX SURFACE OF THE GRANITE . . . . . . . . 53

Fig. 28.-The South Arj, With tablular fratures exhibited ox the left, axd Kinob HEAD ON THE RIGHT. . . . . . . . . . . . . . . 54 FOL. I. 
Fig. 29.-Crystalds OF ICE WHich haVE grown UPON A Fishing lise several fathoms BELOW TIIE LOWER (OR FRFEZINT) SURFACE OF THE SEA-ICE . . . . . . . 55

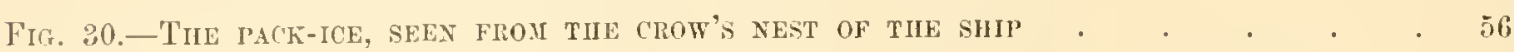

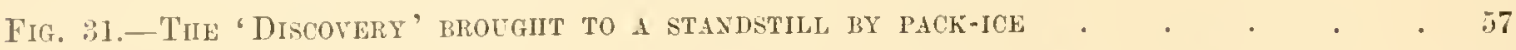

Fig. 32.-Water-iloles in sea-ice at Cape Aruitage axd Hut Ponnt in Jandary, 1904. 048

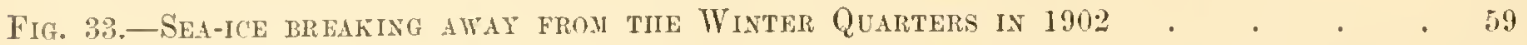

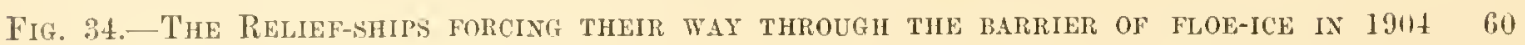

Fig. 35.-Tine ICE-Foot at Hut PoInt . . . . . . . . . . . . . 61

Fig. 36.-Shore-ice WRAppiag the land year the foot of Castle Rock . . . . 61

Fig. 37.-ICE-Foot axd PaCk-ICE in Wood Bay at foot of Mount Melbourse . . $\quad 65$

Fig. 38.- The Ross Piedyont frox the side of Mount Terror, showing the Cliff-edge AND FLAT UPPER SURACE. . . . . . . . . . . . . 68

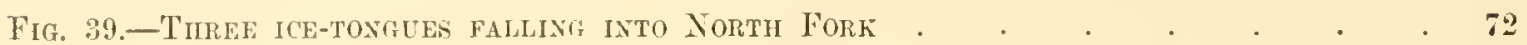

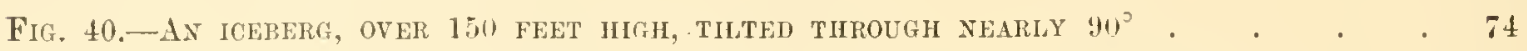

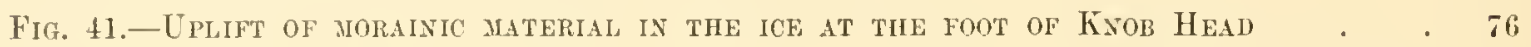

Fig. 42.-THE DARK BAND OF ICE-WITHOUT-GRAIN, BELOW NORMAL GLACIER-ICE, at THE FOOT of Kхов НеAD . . . . . . . . . . . . . 77

Fig. 43.-Moraine on the Ferrar Glacier . . . . . . . . . . . . . . 78

FIG. 44.-GLACIER-TABLE FORMFD BY a LAYER OF GRAVEL . . . . . . . . . 79

Fig. 45.--Moraines on floating ice at the mead of McMurdo sound . • . . 80

Fig. 46.-Morane-cone of iCE-SCRATChed stones, on Which the Balants shells Were

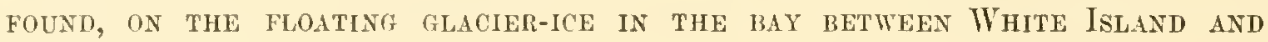
BLack Island . . . . . . . . . . . . . . . 80

Fig. 47.-Moraines supported by ice, on tile West sme of Mcllurdo Sound) . . 81

Fig. 48.-Undulating surface of ilard " Marbled" sNow . . . . . . . 84

Fig. 49.-Tile two lower men are standing upon the UpPeir surface of SEA-ICE DEPRESSED BY SNOW BELOW WATER-LEVEI, . . . . . . . . . . . 85

Fig. 50.-Hollowed grayte-bollder with incrlstatiox of Calcium carbonate, dear

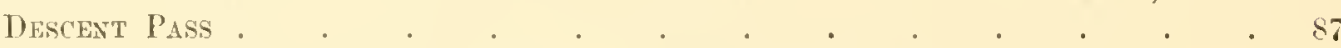

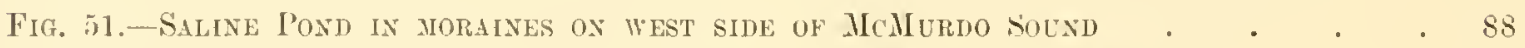

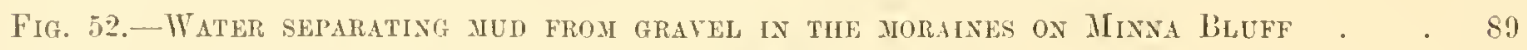

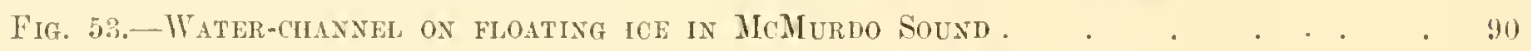

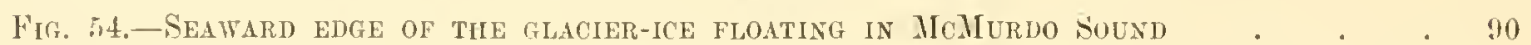

FIf. 65.--FraCtURED DOME IN THE FlOATING GLACIER-ICE, NEAR TIIE SPOT WHERE SODIUAI SULPIATE CRYSTALS WERE FOUND, TWO MILES FRON TIIE NORTII END OF WIIITE ISLAND

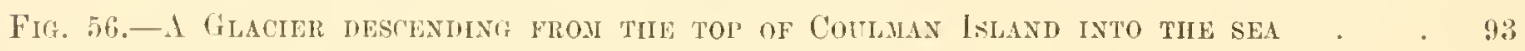

Fig. 57.-The strand any the steep coast-line of tile east sine of Macquarie Island . 95

Fig. 58.-Tife south side of Ross Harbour, Auckland Istands, shomiar subuerged ralders 97

Fig. 59.-Pseudomorlil after horkblende, in basalit (691) Froy Castle Rock, silowigg INCLUSIONS OF APATITE. (Magnification, 10 diam.) . . . . . . 10:3

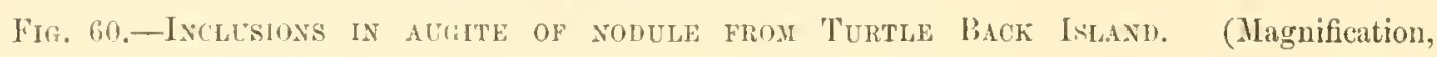
100 diam.) . . . . . . . . . . . . . . . $10 \mathrm{k}$

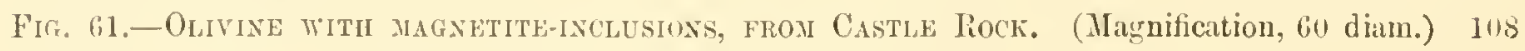


FIG: 69- K

Fig." 62.-Kenyte with PORPHyitic anorthoclase, boulder from Turtle Back Island • 110

Fig. 6\%.--Spherule With Magnetite, in glassy kenyte, frovi Turtle Back Island. (Magnification, 200 diam.) . . . . . . . . . . . . . . . 111

Fig. 64.-Leucite-crystals in base of glassy hornblende-trachyte (261) From Observation Hild. The prishatic CRYstals are gostly aUgite: the long oNe at the TOP IS HORNBLENDE. (Magnification, 150 diam.) . . . . . . . 118

Fig. 65.-Dendritic magnetite in glassy base of trachite froa Observation Hill.

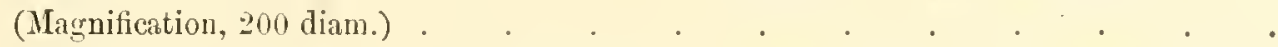

Fig. 66.- Hornblende-inclusions in the trachyte of Observation Hill. (Magnification, 150 diam.

Fig. 67.-Graphical Representation of the Chenical conposition of the Olivine-Basalt (656) FROM NEAR THE GAP

\begin{tabular}{l} 
Fig. 68.-Graphical representation of the chemical composition of the leucite-kenyte \\
(818) From Cape Rojds \\
\hline
\end{tabular}

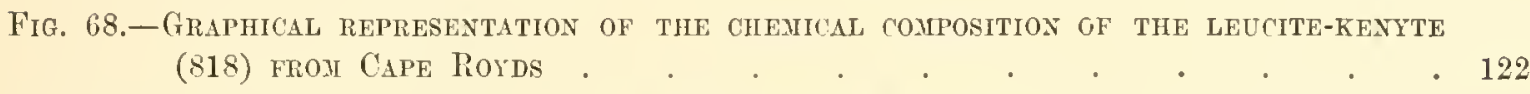

Fig. 69.-Crystalline linestune Witu chondrodite, from Sodthern Foothills. (Natural size) 124

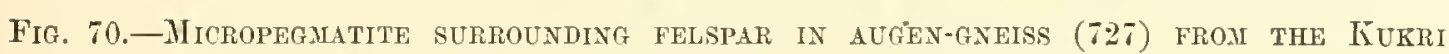
His.s. (Magnification, 25 diam.) . . . . . . . . . . . . 125

Fig. 71.-Quartz-grains in Beacon Sandstone (679) from Inland Forts. The dotted LINES SHOW THE ORIGINAL ROUNDED OUTLINES OF THE GRAINS. (Magnification, 20 diam.) . . . . . . . . . . . . . . . . . . 134

Fig. 72.-Micropegmatite in dolerite (662) From Depôt Nunatak. (Magnification, 100 diam.) 136

\section{PLATES.}

(At end of volume.)

Plate I.-A Paxorana of Mount Terror froni the south-east.

Plate II.-A Panorana of Winter Quarters, showing Harbour Heights, Crater Hill and Observation Hili.

Piate III.-The north end of the Royal Society Raxge, and the south side of the Kukri Hills. Looking ep Ferrari Glacier frodi Descent Pass.

Plate IV.- Tiew down the East Fork of the Ferrar Glacier, shomixg the lom granite-

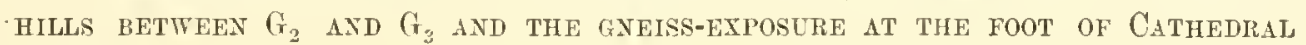
Rocks.

Plate V.-A Panoralla of the south side of the Ferrar Glacier as seen from a point above the holitary Rocks.

Plate TI.-The overflow of the Foettitz Glacier into a tributary valley containing AN ICE-SLAB.

Plate VII.-Geologicai, Sections.

Section I.-Fron east to Mest across time Royal Society Raxge, frour Mlifurdo SOUND TO THE INLAND-ICE.

Section II.-From south to north, across East Fork, the Kukri Hills axd NoRTH FORK.

Section 11I.-Fron west to east along the Kukri Hills. 
Plate Vili.-Fig. 1.-Olivine-Basalt (656) froj cliff ietween Gap and Horseshoe Bay (p. 104).

Fig. 2.-Gabbro-like nodule (415) in Iimburgite, fro.i Wixter Quarters (p. 108).

Fig. 3.-Leucite-kenyte (818) from Cape Royps (p. 111).

Fig. 4.-Phojolitic trachite (248) from Mount Terror (p. 115).

Fig. 5.-Phosolite (530) Frow Blach Island (p. 116).

Fig. 6.-Phosolitic horndlfade-trachite (277) from Observation Hill (p. 117).

Plate IX.-Fig. 1.-Augen-Ganiss below D, Kukri Ifilis (p. 125).

Fig. 2.-Diorite (715) froni Cathedral Rochs (p. 125).

Fig. 3.-Diorite to essexite (572) from the Blue Glacier (p. 128).

Fig. 4.- Kersantite (579) from Northers Footilllas (p. 130).

Fig. 5.-Camptonite (839) from Soutinern Foothilis (p. 129).

Fig. 6.-Dike-rock ( 71 ) related to banakite, fros the Northern Foothilds (p. 131).

Plate X.-Fitr. 1.-Dolerite (662) frou Depôt Nunatak (p. 136).

Fif. 2.-Dolerite (696), 2 ft. from junction with sandstone, Dri Valleys (p. 138).

Fig. 3.-Dolerite (687), 6 in. Fron junction Witi sandstone, Inland Forts (p. 138).

Fig. 4.-Dolerite (695), 2 in. fron junction with sandstone, Dry Valleys (p. 138).

Fig. 5.-Junction of dolerite and SANDStone (669) at B (p. 138).

Fig. 6.-Dolerite (15t) with granitic patcies, Granite Harbour (p. 139).

MAPS.

(In pocket at end of volume.)

Chart of the Axtarctic Ocean between Lat. $66^{\circ} \mathrm{S}$. and $83^{\circ} \mathrm{S}$., and Long. $150^{\circ} \mathrm{E}$. and $150^{\circ} \mathrm{W}$. MIap of the District Near the 'Discoyery' Winter Quarters. 


\section{REPORT ON THE FIELD-GEOLOGY}

OF THE REGHON EXPLORED DURHG THE

\section{'DISCOVERI' ANTARCTIC EXPEDTTION, 1901-4. \\ By II. T. Ferrar, M.A., F.G.S., Geologist to the Expertition.}

\section{Chapter I.}

\section{ISLANDS, CIIEFLY OFF THE COAST OF SOUTH VICTORIA LAND.}

The part of South Victoria Land known to us eonsists of a great range, or series of mountain-ranges, stretehing in an almost straight line from latitude $71^{\circ} \mathrm{S}$. to lat. $82^{\circ} \mathrm{S}$., a distance of about 800 miles. Some of the mountains rise to a height of 13,000 feet, and it is remarkable that there is no extensive area of land lower than 4000 feet. Off this bold eoast-line is a shallow sea (Ross Sea), with oeeasional islands arranged along a line roughly parallel to the coast and elose in under it.

The earliest specimens brought back from the Ross Quadrant were those obtained by Captain Baldexy in the year 1839 from the Balleny Islands. Shortly afterwards the 'Erebus' and 'Terror ' Expedition under Sir James Clarke Ross brought back rockspeeimens from other outlying islands, and until the year 1895 no additional specimens of Antaretic rocks were obtained from this area. It was also known that (1) the Billeny Islands are volcanir, one of them possessing an active voleano; (2) South Victoria Land consists of a great range of mountains probably voleanic, ${ }^{*}$ and with at least one volcano still active. The specimens include seoria and olivine-basalt from Young Island, one of the Balleny group, $\dagger$ basalts, palagonite-tuffs, and granites from the largest of the Possession Islands, and basalt from Franklin Island, one of the isolated islands off the coast.t

A Freneh expedition contemporary with that of Ross also obtained granites from

* Ross, 'Voyage in the Southern and Antarctic Regions, 1839-43,' 1847, vol. ii, p. 415.

$\dagger$ 'The Antarctic Nanual' (Roy. Geogr. Soc.), 1901, p. 341.

† Prior, Mineralogical Magazine, 1899, vol. xii, p. 91.

$\S$ 'The Antaretic Manual' (Roy. Geogr. Soc.), 1901, p. 449. 
low roeky islets lying off the eoast of Adélie Land, and these strongly suggested the existence of a continental mass of land.

The fact that bloeks of gneiss and granite, probably dropped from ieebergs, were dredged up in high southern latitudes during the 'Challenger' experition was also regarded as evidence of the existence of a continent. Fragments of mica-schists, sandstones, limestones and shales, were also dredged up at the same time.* This fact was sufticient to render it extremely probable that sooner or later fossiliferous sedimentary rocks would be discovered.

In the year $1895 \mathrm{Mr}$. BoRchgrevrok ohtained schistose and granitic rocks from Cape Adare.

The 'Southern Cross' collection described by Dr. Prior $\dagger$ includes various plutonic and roleanic rocks as well as siliccous slates, the latter being apparently the first sedimentary rocks found in situ in Soutl Vietoria Land. The slates are noted as oceurring at the head of Robertson Bay. These slates are directly covered by the basalts of Cape Adare on the east, and they have been followed northward along the const for some five miles.

The islands may be conveniently considered in the order of increasing latitude, commencing with the Balleny group near the Antaretie circle.

\section{Balleny lstuands.}

This group consists of five islands lying between longitudes $161^{\circ} \mathrm{E}$. and $165^{\circ} \mathrm{E}$, and latitudes $66^{\circ} \mathrm{S}$. and $68^{\circ} \mathrm{S}$, that is to say, ahout the Antaretic eirele. They were discovered by Captain BArLenY in 1839. He brought back speeimens from Joung Island, and reported the presenee of an active volcano on Buckle Island, a report ufterwards eonfirmed by the 'Southern Cross' Expedition.+

Roue Island, the most northerly of the group, was very distant from the 'Discovery's' track. Balleny remarks that it is low and offers no remarkable feature.

Young Island, one of the largest, is roughly 10 miles long and 5 miles broad, and, aecording to BALLENY, is the highest. It rises to an estimated height of 12,000 feet. It is girt by a high eliff and has the form of a terraeed cone. The rock-speeimens collested here in 1839 were the first obtained from what is now linown as the Ross Quakrant. They "prove to be scoria and basalt with erystals of olivine." $\$$

Borradaile Island is abont 500 feet high and 2 miles long, and, like the others, is bounded by vertical cliffs.

\footnotetext{
* See also 'Nature,' 1898, vol. Ivii, p. 420.

† Prior, Rep. 'Southern Cross' Collections (British MIuscum), 1902, 1). 325.

‡ 'The Antaretic Manual' (Roy. Googr. Soc.), 1901, pp. 499, 500.

$\$$ 'The Antarctic Manual' (Toy. Gcogr. Soc.), 1901, p. 341.
} 
Buckle Island, which bears the active volcano, is probably 15 miles long. The surrounding cliff varies from 100 to 1000 feet in lieight, while above it the land rises as a dome to a height of about 4000 fect. The volcano is situated on the north end, which is otherwise low and flat.

Sturge Island (Fig. 1) is about 20 miles long and 7 broad, and rises to a height of over 10,000 feet. It is elaviform and smooth in outline, and appear's as an elongated dome surrounded by a rock-eliff which varies from 1000 to 3000 feet in height. At the north end are seen roughly parallel irregular lines, dipping at an angle of about $15^{\circ}$ to the west. Approximately parallel to them are numerous conspienous lenticular bands of light-yellow colour. The soundings in this area are uniform over great

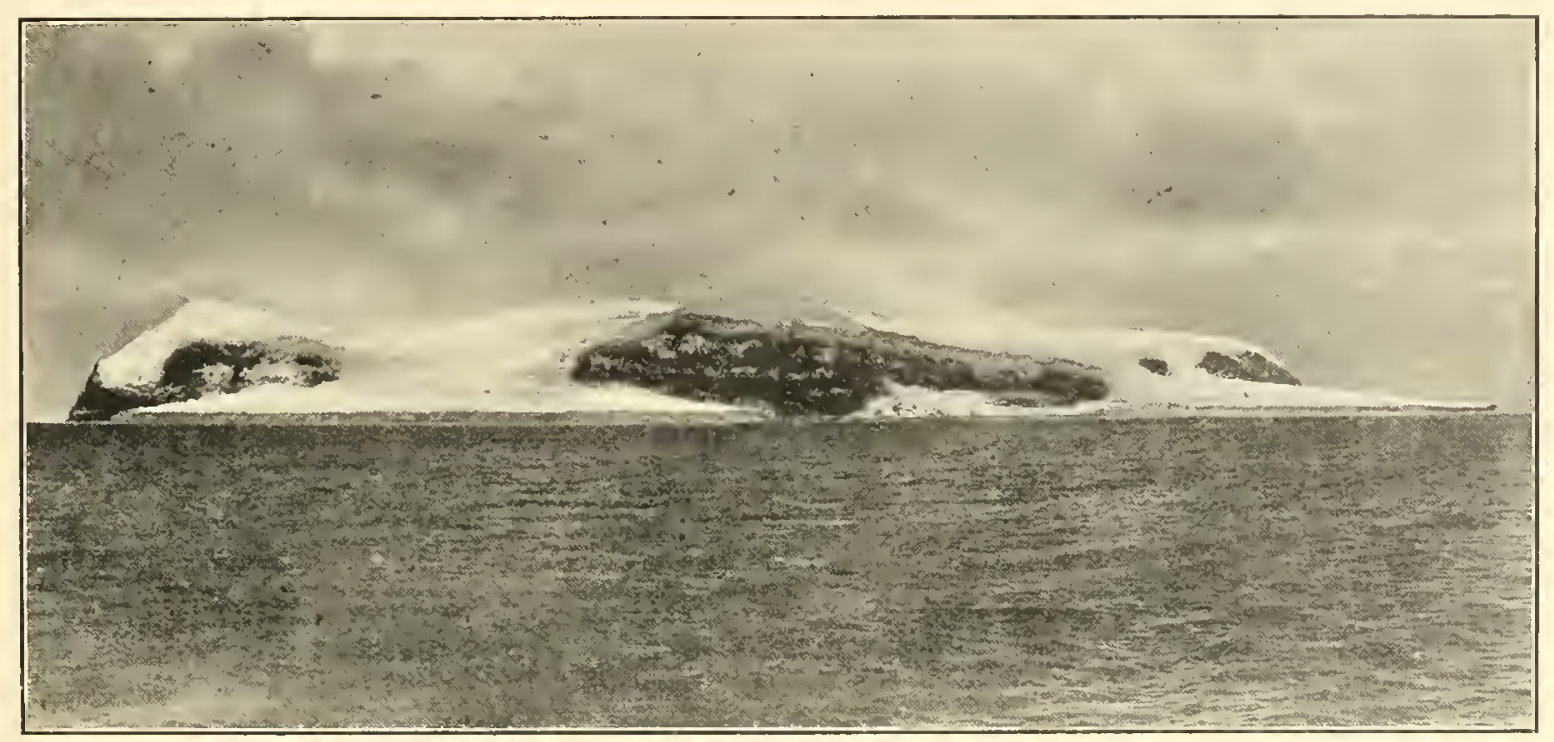

Fig. 1.-Sturge Istand, Balleny Islands, showing transition from "Piedmont-aground "to "Piedmont-afloat."

distances, ranging from 260 to 270 fathoms. The sea-bottom is covered with a mixture of roek-flour (902) * and iee-scratehed stones (866), * including frigments of dolerite and micaceous schists (sce pp. 135 and 139).

\section{Scott Islands.}

The Scott Islands were discovered by Captain CoLBeck in December, 1902, $\uparrow$ and are flat-topped rocky islets, which rise 300 feet sheer out of the shallow sea. The smaller is practically an isolated pillar (Haggitt's Pillar), while the larger is about two miles across. Mr. J. D. Morrison landed on the larger island and collected specimens of a trachytie roek (see p. 114) regarding which he gave the following information:-"No. 1 was taken from the south-east sirle, lat. $67^{\circ} 24 \cdot 5^{\prime} \mathrm{S}$., long. $179^{\circ} 55 \cdot 5^{\prime} \mathrm{W}$,

* The numbers refer to the author's List of Specimens.

† Colbeck, Geog. Journ., 1905, vol. xxv, plate, p. 402. 
lueing broken off the highest aceessible point, about 12 feet above water-level. The strata seemed about 2 feet thiek, dipping to the south-east side at an angle of $45^{\circ}$, striking S. W. and N.E."

\section{The Possession Islanus.}

This group consists of two large and five small islands, elose under the lighlest peaks of South Vietoria Land and about 5 miles off shore and a little north of the $72 n d$ parallel of latitude (Fig. 2). They were discovered by Sir Jayes Clarise Ross in 1841, when a landing was made and rock-specimens were collected. They include basalts, palagonite-tuff, phonolite, and fragments of granite, but the latter were probably not found in situ.* Mr. C. E. Borchgrevink and Captain Jessses both landed here in

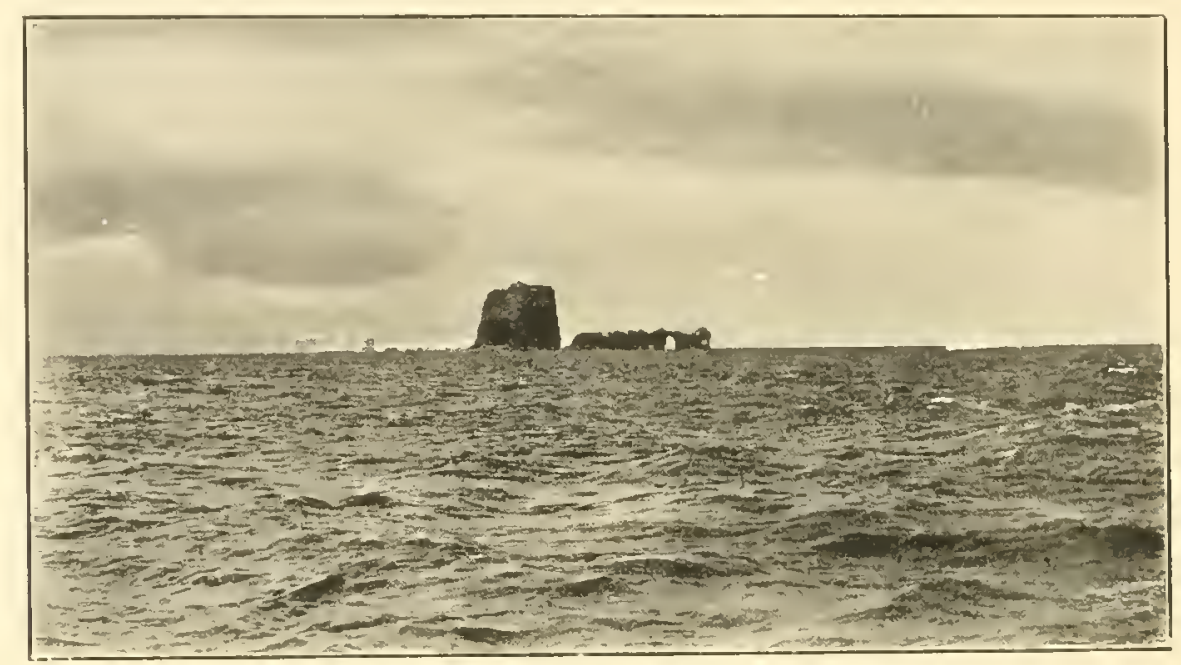

Fig. 2,-Two of the Possession IsLaNds.

THE TALLER ONe sHows THE JUNCTION OF TwO TYPES OF ROCK.

1895, and eolleeted rock-material. The specimens brought back by the former have

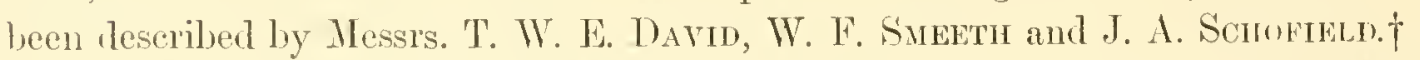

In December, 1902, Mr. Morrison, landing from the relief ship 'Morning,' collected roek-specimens. He obtained only two types of rock in situ: one (No. 2) is a palingonite-tuff and the other (No. 3) a grey hornllende-basalt. He gave the following information relative to them :- "No. 2 was taken from the south-west shore of Possession Island, 18 feet albove water-level, lat. $71^{\circ} 56^{\prime}$ S., long. $171^{\circ} 10^{\prime}$ E. There are no signs of stratification, lunt there is a very distinet vertical line-of-parting between the rorks forming Nos. 2 and 3. No. 3 was taken from a piece of iee floating close in shore on the S.S.E. sile. The clifts are about 150 feet ligh and overhminging."

From the view seen from the deck of the 'Discovery,' it would appear that the higher part is eomposed of palagonite-tuff, and the south side, ending in a hold eliff 300

* Prior, Mincralogical Magazine, 1899, vol. xii, p. 75.

† Journ. Iloy. Soe, New South Wales, 1895, vol, xxix, pp. 461-492, 
feet high, of basalt. This island, the largest of the group, is 2 miles long in a northand-south direction. The landing place is at the northern end, whieh is low, flat and prominently terraced. The next largest island may be a mile aeross: like the first it has rertical sides. Of the other islands, three are flat-topped, about a quarter of a mile in diameter, and 50 feet high. They appear to be roughly reetangular in shape, and have bare vertical sirles. A fourth forms an isolated pillar appearing to be made up of vertical eolumns, while a fifth is less than a quarter of a mile aeross and over 100 feet high. This last shows an uneven junetion of two rocks at ahout 50 feet above the sea (Hig. 2). The distribution of snow wonld seem to show that the rocks are tuft and basalt, the tuff being uppermost. The junction is irregular, but on the whole slopes from west to east, away from the high land.

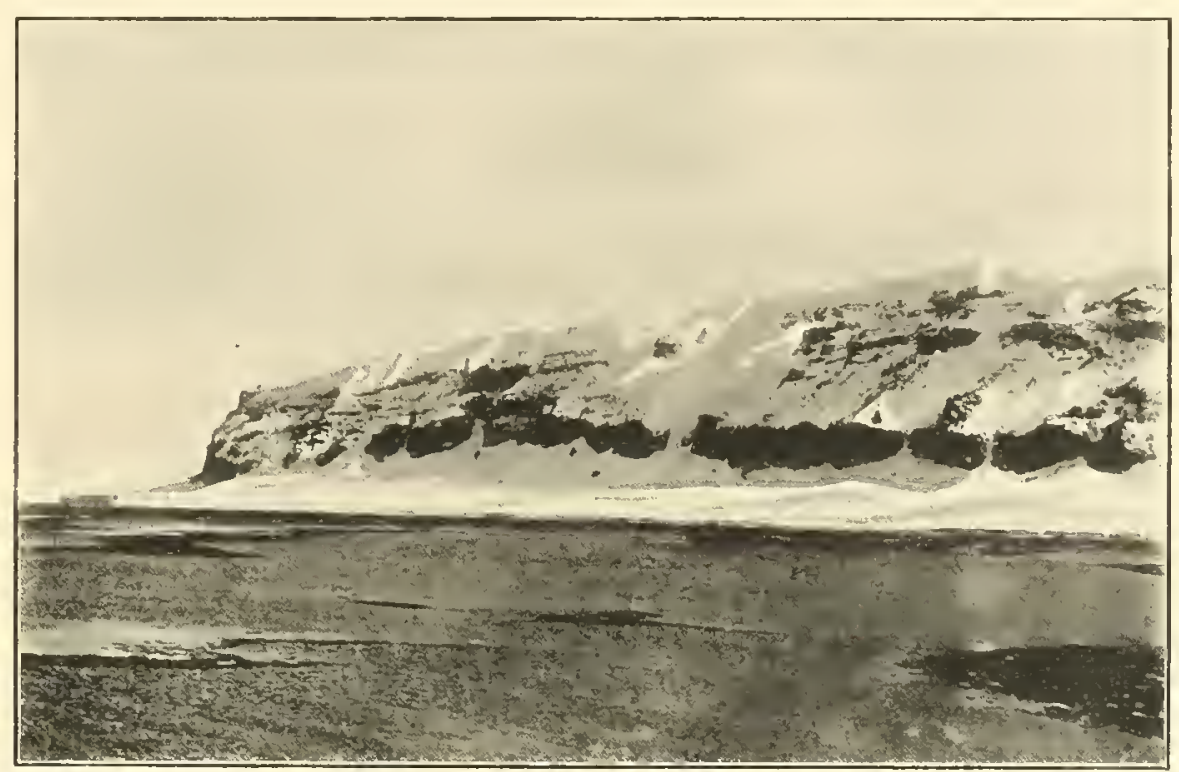

Fig. 3.-East side of Collmain Island, showing the horizontal structure of the rocks, AND the "PiednoNt-Aground" which surrounds the island.

\section{Coulman Island.}

This island is situated in latitude $73 \frac{1}{2} \mathrm{~S}$., longitude $170^{\circ} \mathrm{E}$. It was discovered by Sir Janies Clarke Ross, but the first roek-speeimens were brought baek by the 'Southern C'ross' expedition; they were determined to be hornblende-basalt and lasalt-agglomerate, ${ }^{*}$ but $n o$ details were given as to the distribution of the rorlis. Here also the land is charaeterised by bare roek-eliffs more than 1000 feet high, which fall sheer away to the sea. The island has an even outline. Its top is nearly flit at Cape Wadworth, the north end, but at the south end rises to nearly 3000 feet. It is about 20 miles long, and arerages 7 miles in breadth. Cape Anme, the south end, terminates in a bare cliff over 2000 feet high. It shows chrome-yellow patches in several places,

\footnotetext{
* Prior, Rep. 'Southern Cross' Collections (British Museum), 1902, p. 322.
} 
and, by analogy with the yellow lenticular patch of basalt-agglomerate (82) at Cape Watworth, we ma infer that the south end is also partly of the same rock. As the yellow patches lie ahmost horizontally it is lighly probable that the island consists of alternating sheets of basalt and basalt-agglomerate (Fig. 3).

In addition to bedding-planes visible near Cape Wadworth, there are dykes running verticilly up the clift's. Among the specimens collected by the 'Discovery' from this Cape, there are basalt-scoria (80), basalt-agglomerate (82), and a basalt (81) obtained from a dyke standing out on the cliti-face. Such dykes do not reach the top of the cliff but, after extending some way up a steep slope, end off at the base of the agglomerate. Only a quarter of an hour could he allowed on shore, but as the ship steamed into Lady Newnes Bay quite similar structure-lines were seen on the west side of the island and on the mainland (Cape Jones), areas which were possibly at one time continnous. The distribution of snow on the west sicle of the island points to gentle folding of the rocks about an east-and-west axis, but soundings of over 150 fathoms in the channel show no eontinuation of this fold towarls the west.

\section{Franklix Island.}

Franklin Istoned is situated in latitude $76^{\circ} 8^{\prime} \mathrm{S}$. and longitude $168^{\circ} 12^{\prime} \mathrm{E}$, and until the 'Southern Cross' Experlition this was the most southerly lanel from which rock-specimens had been obtained. The island was diseovered by Sir Jayes CLARKe Ross, who gave its length as 12 miles and its breadth as 6 miles. He deseriber its north sirle* as a line of dark precipitous cliffs between 500 and 600 feet high, exposing several longitudinal broad white hands and two or three bands of a red-ochre colour. The specimens he collected are all basalts of one type, $\dagger$ while in the 'Southeru Choss' collection there is a specimen of magma-basalt (limburgite) remarkable for the number and large size of the olivine-enstatite nodules.

From Mr. J. D. Morrison of the 'Morning' five specimens of similar magmabasalts with olivine-cnstatite nolules were received; with them was the following note:- "Nos. 4 and 5 were taken from Franklin Island, from a belt of rock about 30 feet thick rumning horizontally along one side about 300 feet above sea-level. Height of liill about 700 feet; very difticult to ascend, as the slope is conposed of small stones lying at an angle of about $45^{\circ}$. Nos. 6 and 7 were broken from a large bonlder lying at the foot of the hill. The beach is about half a mile hroad and a mile long, almost flat and about 10 feet above sea-level. Large boulders and heaps of shingle are scattered over the beach, which is on the south-west curner of the islaml."

\footnotetext{
* Ross, 'Voyage in the Southeru aud Anturetic legions, 1839-43,' 1847, vol. i, p. 215.

+ P'rior, Mineralogical Magazine, 1899, vol. xii, p. 79.

† L'riol, Iiep. 'Southern Cross' Collections (British Muscum), 1902, p. 328.
} 


\section{Beaufort Islajt.}

This island lies in latitude $77^{\circ} \mathrm{S}$, longitude $167^{\circ} \mathrm{E}$, and about 12 miles off Cape Bird, which is the north extremity of Mount Erebus. Sir Janes CLarke Ross described it as small and conical; * we saw it from many points of view and estimate its length to be 5 miles, its breadth 2 miles, and hcight 1000 feet. It has a rugged outline, with a very steep snow-covered slope on the west side and a bare precipitous cliff on the east side. Its summit is a narrow ridge rumning north-and-south. No specimens have been obtained from this island.

\section{Table of Distances.}

A brief table which shows roughly the distances hetween some of the voldanocs and islands will not be out of place here.

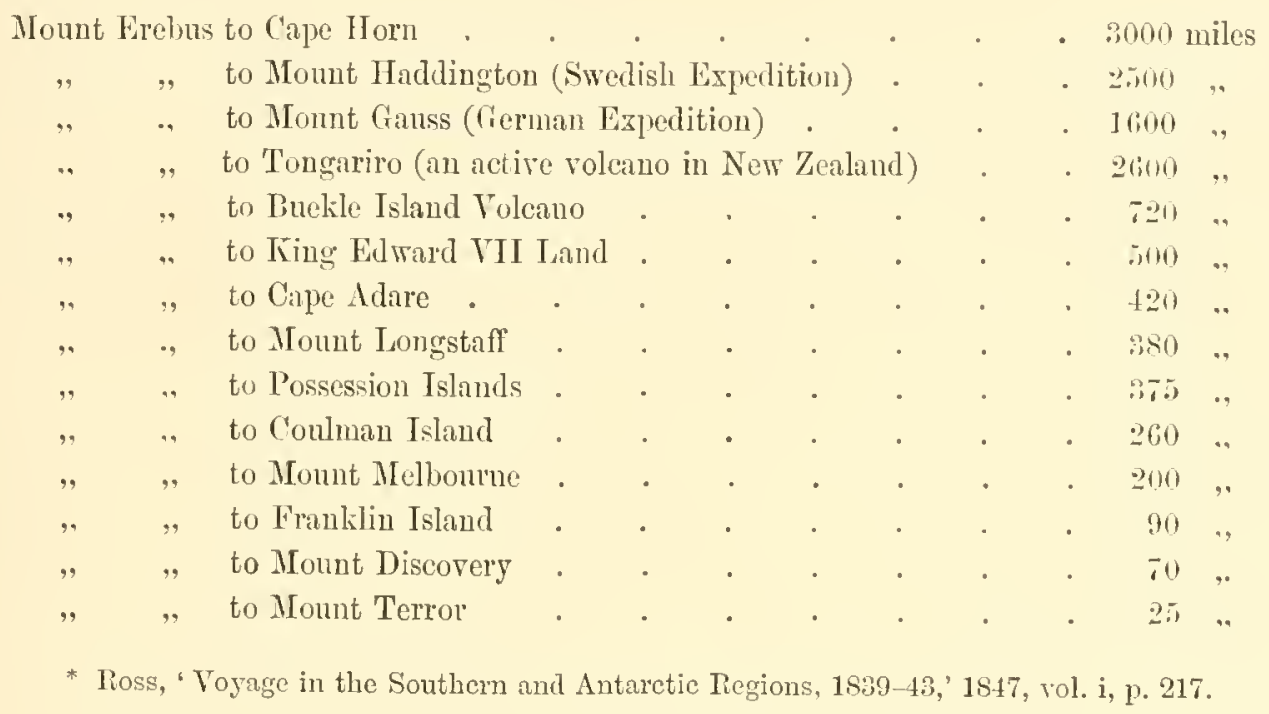




\section{Chapter II.}

\section{THE ROSS ARCIIIPELAGO.}

This gromp of islands includes practically all the land within 50 miles of the 'Discovery's' winter quarters, and is the most extensive area not directly joined to the mainland. The group is important because it has long been a centre of volcanic activity, whirh continues even to the present day.

\section{Ross Island.}

Ross Fismel is practically made up of the voleanie cones, Momts Erebus and Terror, Cape Bird (Mount Bird, as it may be called), and another convex dome, Mount Terra Nova, lying between Mlount Erebus and Mount Terror. 'This istand therefore consists of four distinct volcanoes, and of these the greatest, Mount Erebus, is still active. This mass of ejected material lies between latitudes $77^{\circ} 9^{\prime}$ and $77^{\circ} 49^{\prime} \mathrm{S}$., and longitudes $166^{\circ} 8^{\prime}$ and $169^{\circ} 10^{\prime} \mathrm{E}$. It forms an island having roughly the shipe of an equilateral triangle with a sicle of 50 miles.

Soundings in the waters around this island are unfortunately incomplete, but the few that we lave would seem to show that the depth is greatest close to the shore and decreases gradually outwards. Whether or not this anomalous deopening is due to overweighting of the crust hy so many huge volcanic piles close together is not clear, bint the oceurrence is suggestive.

Hount Lidus (Fig. 4) is 12,922 feet high, and was active when seen by Sir Jambs ( Poss in 1841, "emitting flame and smoke in great profusion." * During our two year's stay in Winter Quarter's at its lase the snow was always white and continuous to the summit, and only steam was ever seen to be erupted. On three sides the mountain rises directly from sea-level, and has flowing convex curves, which give it a very massive and molenuded aspect. Three stages in its history appear to he recorled in its contours. Of these the first was by fur the most violent, and produced a cone with crater about 8 miles in diameter. The walls of this still stand, amd encirte it as a girdle about 6000 feet above sea-level. In profile, on the north side this ring appears as a strong ontstanding crag, and is separated from the mountain-side hy a deep noteh, white on the south side there is only a mere shoulder to interrupt the regular convex "urve. The second stage is rendered evident by the existence of the lip of a later "rater at a height of nearly 11,000 feet. Old lava-streams from it, swept hare of snow, ran now be seen. The latest stage is recorded hy the present small cone, which hias been built up asymetrically within the second, and from this stean now issues. 1).

* Ross, 'Voyage in the Southern and Antarctic liegions, 1839-43,' 1847, vol. i, p. 216. 
WiLson has recorded five or six other steam-jets issuing from the north-east side, but from the ship it was unusual to distinguish more than two. Mount Erebus bears a very striking resemblance to Mount Etna as shown in von Waltershadsen's picture, and is much more dome-like than is suggested by the published pictures of the betterknown active voleanoes.

Owing to the difficulty of access, few rock-specimens could be obtained from Mount Erebus itself. Specimens, however, were got from the following localities: (a) The Turk's Head, a bare cliff which rises sharply from the sea to a height of about 300 feet on the south-west side of the mountain. Mr. Hodgson tells me that the tuft's which build up this headland are exposed for a length of about 200 yards along the shore, are bedded, and dip to the north-west at an angle of neirly $40^{\circ}$. (b) Cape Royds, a promontory on the west side of Mount Erebus, having an area of about 3 square miles. This arca is bare of snow, and consists of dyke-outpourings of basalt with lenticular crystals of felspar (818) (leucitekenyte, see p. 111). The Cape is rectangular in shape and displays many outstanding dykes which rise to heights of 200 and 300 feet, but are now heing rapidly disintegrater. A similar, but vesicular, rock (lava) (820) forms a small knoll, 1500 feet up this side of Mount Erebus, but, as the rest of the

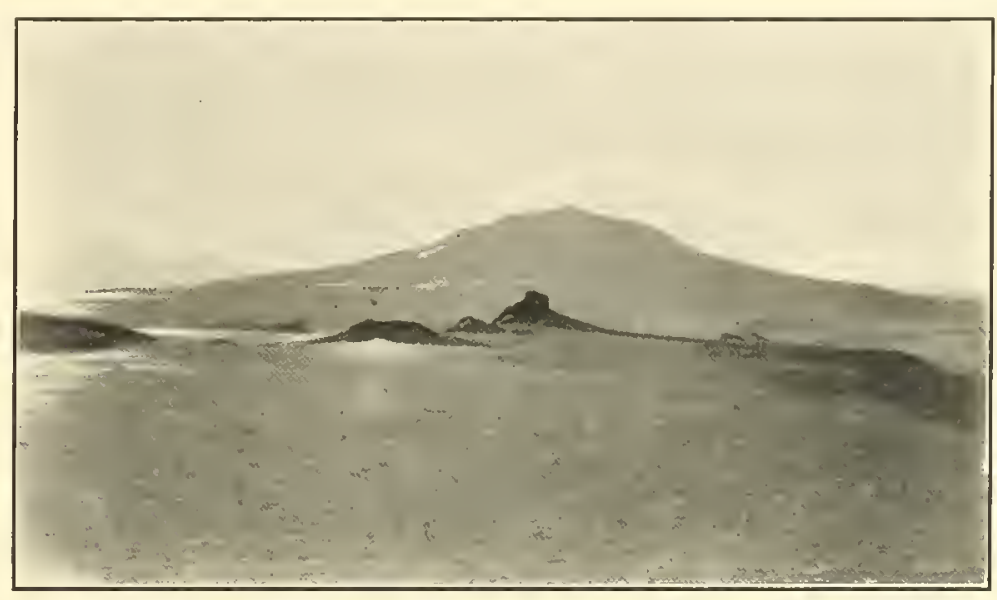

Fig. 4.-Castle Rock and Mount Erebus. surface was covered with snow, no relations between these rocks could be marle out. (c) Caye Barne, the bare rocks which lie about 3 miles south of Cape Royds and are separated from the latter by a shallow bay. The Cape consists of black vesicular basalt-lava (813) which dips to the west away from Mount Erebus. The extreme end of the Cape is a pinnacle rising 200 feet sheer from the sea, and is separated from the main mass of the Cape by a scree which prevents the junction of the vesicular rock and the basalt-agglomerate (815) of the pinnacle being seen. (d) The Skutry, an area of bare land, between Cape Barne and the Turk's Head. This is about 2 square miles in extent, and except along the shore, where rock in situ is visible, is covered by moraines. The moraines include fine tuff's (808) and a compact, grey alkaline-basalt or kenyte (812) containing parallel lenticular crystals of felspar. Below them, and extending to the shore, resicular glassy basalt-rock (811) of the same character is seen in situ. This last is over 100 feet thick, and appears to consist of 
sueressive lava-flows laid horizontally one upon another. These rocks are similar in character to the lavas with lenticular felspars of Cape Royds, and are also related to the rocks of the neighbouring Dellbridge Islands, to be considered later.

Hount Bird is a flattened dome over 3000 feet ligh and, like Mount Terra Nova, which attains a height of about 7000 feet, is an undenuded voleanic cone. No specimens have been obtained from either of these mountains.

Mount Terror (Plate I) is a quiescent voleano 10,750 feet high. It forms the castern part of Ross Island, and, though not quite so lrigh as Mount Erebus, covers almost as great an area. Its base is circular and has a diameter of perhaps 20 miles; its surface is almost completely snow-covercd. On the south side the covering is so thick that no parasitic vents, if present, could be distinguished. On the north side, especially above Cape Crozier, is the largest area of rock-exposure, and here all eninences which have been examined were of the nature of sulsidiary

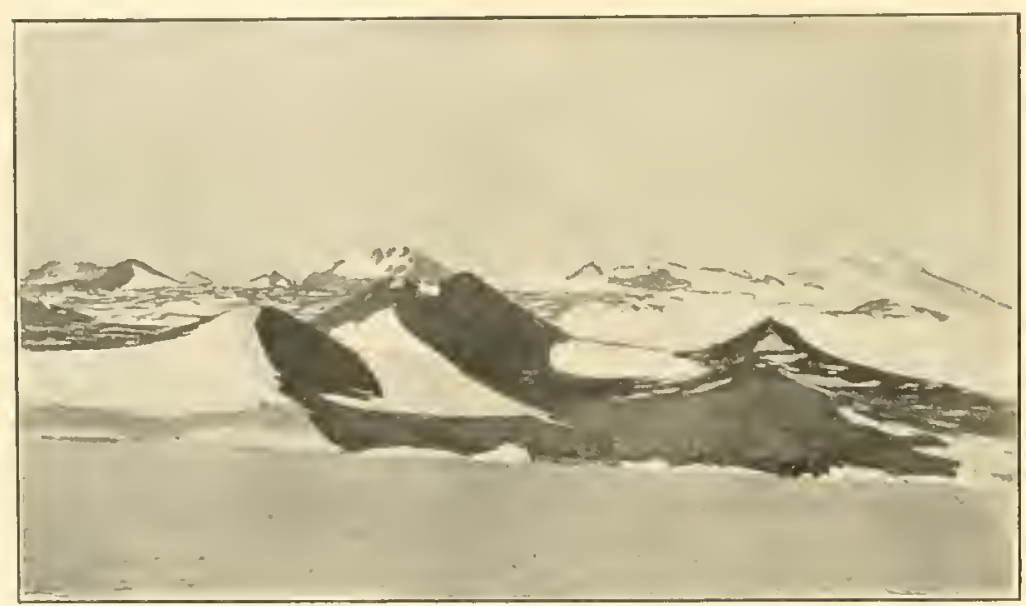

Fig. 5.-Cape Crozier and Mount Terror. surface lava-flows. Some of these are quite conspieuous, and from them many specimens have been collected.

The 'Souther'n Cross' Expedition* obtained lormblende-basalts from a hare roek-chift 10 miles or so to the west of Cape Crozier, and from the red and yellow "blazes" that occur in this eliff it would seem that hasalt-agglomerate is also present. From the cones on the east sile of the mountain above the Great lce Pilrier of Ross, Dr. Wilson collected basalt-scorie (824) and limburgite (825) and proved the cones to be due to subsidiary eruptions. From the hare rock-cliffis (Crozicr (Clift's), against which the ice-sheet abuts, Dr. Wilson also collected rock, in situ. Ilis speeimens are of two kinds: (1) columur basalt (830 and 848), which forms the mass of the cliff's and reaches a height of 800 feet above sea-level; and (2) a yellow trachytic rock (831), occurring in irregular lenticles in the mass of the cliff. At one spot a rongl stratification was olsserved, and it is possible that stratified tufls are there developed.

From a locality he termed the V-Clifis. Ilegturek, Mr. Jodgson rollected specimeus of contre yellow tuff (783), real vesicular hasalt (778) and a hasaltic boub (776). This locality is on the soutl-cast side of Hount 'Terror, 20 miles south of Cape Crozier and 30 from the ship. It is one of two exposures which have heen found on

\footnotetext{
* Prior, Rep. 'Southern Cross' Collections (British Museun), 1902, p. 322.
} 
the south side of the mountain. The other exposure has been termed the Sultan's Head, and Mr. Hodgson here ohtained some bedded yellow tuff's (785 to 793), also some fragments of vesieular basalt (795).

At Cape Crozier (Fig. 5) itself, at sea-level, a stratified palagonite-tuff (228 to 230) was seen bedded parallel to the present slope of Mount Terror and dipping to the west beneath a basaltic lava-flow. This tuff is brown in eolour and is very friable, erumbling easily into rounded pellets about an eighth of an inch in diameter. The surface of the roek was whitened by erystallisations of hydrated sodium sulphate (glauber salt). Bombs and a great variety of voleanie rocks, also granites (197), dolerites (210) and sandstones (214), were found lying about at this height, but these were usually ice-scratehed (186). A boss abont 900 feet high appears to be a pipe or plug of some now defunct volcanic vent; the roek (176) is a limburgite eontaining red and green olivine-augite nodules. A rounded knoll of trachyte (224), half a mile east of this boss, attains a height of 1400 feet. Blaek pebbles of glassy basalt $(217,218,219)$, quite similar to the majority of the pebbles composing the terraces a short distanee lower down the hill, were scattered all over the surface of this trachyte-dome, and appeared to have been included in it, but in the short time allowed on shore no trachyte aetually enclosing basaltic pebbles was met with. On the south side, the 900 -foot boss of rock mentioned above adjoins a mass of yellow tuff (231) through which a grey green trachytic rock (188, see p. 114) seems to have been forced. From the ship many other parasitic vents were seen on the slopes of Mount 'Terror, but were not visited.

\section{The Winter Quarters.}

Winter Quarters were taken up near the end of a long peninsula which juts out

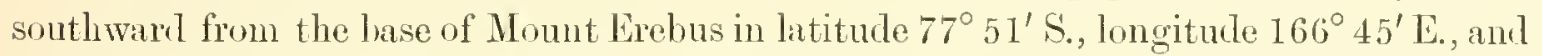
in this distriet not mueh information could be obtained relative to the general geological history of South Victoria Land (Plate II). The peninsula is 10 miles long by 2 miles broad, and has an average height of 700 feet. It is entirely composed of recent volcanie roeks, and only about four of its twenty square miles are free from snow.

At Ilutton Cliff, a stratifier basalt-tuff oceurs as a eliff 500 feet high. This tuffcliff is quite isolated, and is divided into two parts by the snow which falls over the eliff as a small glacier. The northern part $(452-457)$ is composed of rather coarse tuff and is more definitely stratified than the soutlern $(458-462)$; but for eaeh mass the dip is the same, and is about $60^{\circ}$ to the north-north-west. The roek consists mainly of fragments of vesieular basalt-glass and varies from yellowish-green to almost black in colour, but some of the hand-speeimens have reddish lands of palagonite, and other's have inerustations of taleium carbonate. These eliffs are about 5 miles distant from Castle Roek and 10 miles from the T'urk's Hear.

The Sulphur Cones lie on the north side of the peninsula at the foot of Castle liock and at a distance of three miles from the ship, and are so called liecause native 
sulphur was found seattered over their surfaees. They rise 50 to 100 feet above the i.e, and consist of hiack hornblende-hasalt and olivine-hasalt (382-386, see 1\% 103) which liave apparently filled up voleanie necks now undergoing rapil denulation. 'The sulphur (379) is found thickly distributed over the surface of the frost-riven rock and is sometimes in quite perfect crystals.

Castle Rock (Fig. 4), 3 miles distant from Winter Quarters, rises to a height of 1400 feet as a bold crag. It is surrounded by vertieal clifts 400 feet high. On the south the foot of the erag is snow-covered, but on the north the land falls sheer away for 1000 feet. On the east and west sides black basalt can be seen forming the lower part of the crag, whieh consists above entirely of palagonite-tuff (380). 'The tuff varies mueh in texture; sometimes it consists of yellow and blaek angular fragments of olivine-basalt and basalt-glass half an inch across and very uniform in size; in other places the hlack masses attain as muelı as a foot in diameter; sometimes they are almost circular' in section, and are often arranged in parallel rows. 'The summit of the rock is flat and strewn with loose black fragments of olivine-basalt (319), more than two inches in diameter and very uniform in shape and size. About a mile to the northward of this rock occurs another crag consisting of tuff quite like the former and possibly of similar age.

Crater Hill. Along the south-east side of the peninsula there are three scoria-craters. Two of these are rather insignificant, but the third, Crater Hill, rises to a height of over 1000 feet, and the erater-lip at its summit is almost perfect. On the north side the lip rises about 200 feet above the bottom of the arater, but on the south side it has been broken down. The rocks obtained from this hill include black vesicular basalt (341) and red seoriaceous basalt-glass: the latter has obviuusly Howed over the lip of the crater and now forms the highest point of the hill. Near the south foot of ('rater Hill, porphyritic olivine-basalts (656 and 659, see pp. 105-6) rise sheer out of the sea and form a cliff. They appear to extend as horizontal sheets right under both Crater and Observation Hills.

The Harbour Heights, or Arrival Bay /leights, as they have been sometimes called, include the three prominent eminenees between Castle Rock and Hut Point. 'They rise over 100 feet ahove the general level of the snow-covered peninsula. Numerous vesicular olivine-hasalts (323) and basalt-lombs (367) have reeently been ejecterl from these vents, and an occasional flat space, bare of snow, exhibits massive lut vesicular lava-flows of olivine-lasalt (366) (Plate II). These voleanoes have a general resemblance to the Pleistocene* voleanoes of Auckland in New Zealand. Between the southermmost crater of the Harlonur Heights and Crater Ilill there is a basin-shaped depression, the vent of another small volcano. Near this depression ocurs a large rock-mass measuring quite 15 feet acos's and 12 feet high. This rock appears to be the remains of a dyke, and from it the specinens (369-378) were taken. It is a limburgite with abundant foreign inclusions. Of these some are of

* Hutton, Trans. New Zealand Inst. (1899), 1900, vol. xxxii, 1) 178. 
pure transparent felspar', while other's have the mineral momposition of gabbro and peridotite (sce p. 107). Most of the coloured inclusions are quite angular, hut a few are rounded; the largest of them are about three inches long.

On the south-east side of the crater a non-vesicular black olivine-basalt, approaching limburgite in charaeter (326, see p. 105), forms a rugged hillock about 100 feet high. The exposure of rock is quite 50 yards across, but the matcrial is crumbling rapidly away and fresh rock is only obtainable near the summit.

Observation IIill. At the extreme south-west point of Ross Island is Observation Hill, which is separated from its neighbour, Crater Hill, by a narrow col called The Gap. Observation Hill has very steep slopes which make an angle of $40^{\circ}$ to the horizontal, and, almost meeting in a point, produce a strikingly pyramidal hill (Plate II). The sonth-west side slopes away more gradually and terminates in Cape Armitage. This prolongation appears to be due to the presence of a sheet of rock which is bedded horizontally. 'This rock (553) occupies but a small area, about 200 yards long and 50 yards broad. The rock is a porphyritic olivine-basalt, almost black in colour and containing phenourysts of green olivine up to one-eighth of an inch in diameter. Observation Hill appears to have been built up of successive flows of trachytic lava which have welled up through one single outlet. These flows are now to a great extent denuded; but on the south-east side the remains of a sheet ocrupy the greater part of the hillside, and rest upon another similar sheet (412). The lower sheet spreads out and forms the flatter south-east side of the liill.

On the north shoulder of the hill the trachy tic lavas show a rather greater variety of texture, especially near the 400-feet contour. A dark-grey hornblende-trachyte (27:3 and 281), with abundant lapilli-like inclusions (see p. 118), up to an inch in diameter, forms the shoulder on which a perehed block of black vesicular basalt is prominent. The rock with these inclusions has a conspicuous platy structure, and the upturned edges of the slabs into which it weathers may be traced across the Gap to the base of Crater Hill. This platy rock is considerably contorted and its apparent strike is exceedingly variable, sometimes turning through more than two right angles in 50 yards. It is obvionsly older than, and unconformably overlain by, the yellow hornblende-trachytes $(278,279,280)$ of the higher part of the hill. Higher up the bill oceurs a dyke of grey hornblende-trachyte (277, see pp. 117 and 119). The dyke is not more than 10 feet broad, but is traceable 100 feet vertically up the hill. The top of the hill consists of a yellow trachyte; locally it is streaked with grey ribbon-like bands (288) which follow the flow-structure. The weathered surface of the rock is honeycombed, but as here the wind removes the snow immediately after its fall very little frost-action seems to take place. On the sonthern side of the summit the darker roek begins to prepouderate, and at a point some 30 yards away from the top, and 50 feet below it, the yellow rock gives place to a dark-grey horublende-trachyte (290). Below this roek comes another dark-grey hormblende-trachyte with spheroidal structure (655). The spheres which make up the mass of this exposure sometimes attain a diameter of over 2 feet and are visible over 
an area of some 200 square feet. The spheres are all planed off to an even surface, and there is no change in the slope of the hill to correspond with the junetion of the two roeks.

\section{Turthe Back Island.}

Turtle Back Island, low and insignificant in aspeet, lies in the bay between the Winter Quarters peninsula and the ice-tongue in Erebus Bay. It is less than a quarter of a mile long and alout 100 yards broad, is reetangular in plan, and rises to a height of 50 feet. The loose rock-material on the surface of the island is bedded, and the layers of dark rock form a small antieline, of which the axis is the longer or N.E.-S.W. diameter of the island. Two boulders of kenyte (trachydolerite) with lenticular crystals of felspar (447 and 484) were found on this island. They are similar to the roek-speeimens brought from the lower slopes of Mount Erebus, but are more glassy and of a l,lack colour. Black augite-olivine nodules (448 and 451) are common, but the mass of the island consists of fine-grained fragments of olivinelasalt (449).

\section{BLACK IsLAND.}

In point of size Black Island eomes next to Ross Island. It lies sonth of latitude $78^{\circ}$, and is roughly triangular in plan, having a side abont 15 miles long (Fig. 32, p. 58). It shows two central peaks, each over 3000 feet high, and appears to be composed entirely of volcanic roek. It is quite surrounded by glaeier-iee, and is therefore almost a numatak. It is probably connected with White Island. situated to the eastward, by an isthmus rising about 200 feet above sea-level. Specimens from rock in situ were ubtained from a hill, 900 feet high, near the north end of the islind. Compact and vesicular hasalt-lavas $(593,594,595)$ were olstained high up, lut no specimens of rock in situ could be obtained from the lower slopes, which were completely covered with rock-débris. At the south-east end is a yellow trachytie rock $(609,610)$; it appeared to be a dyke nearly a quarter of a mile wide breaking through the black basaltic rock. The roek forms a bold headlind nearly 400 feet, high. The major joints, which are vertieal, strike north-west and south-east, and notalyle variations in the appearanee of the rock occur on cither side of the joints. There are two other apparently similar rock-exposures near this spot, lut time did not permit their examination.

\section{White IsLand.}

This island is 20 miles long, hut is less than 5 miles hroad. Its longer axis is nearly north-and-south; the island lies between the longitudes $167^{\circ}$ and $168^{\circ}$ E., and is south of latitude $78^{\circ} \mathrm{S}$. The land rises very suddenly out of the ice which surrounds it, and attains a height of 2000 feet. The only rock in situ obtained from it is a 
black hornblende-olivine-lasalt (311), which occurs us a boss on the summit. One or two crateriform depressions occur on the lower portions of the islant, and there seems little doubt that the whole island consists of volcanic rock.

\section{"Brown Island."}

This mass of land, about 15 miles long and 5 miles broad, is only apparently an island, for it is connected by a narrow isthmus about 8 miles long to Mount Discovery, a volcanic cone on the edge of the mainland. As the peninsula is so nearly isolated, and bears so great a resemblance to the other islands, it is convenient to include it in this chapter. When the ice was at a maximum "Brown Island" was certainly cut off from the mainland, which lies to the west. If the moraines covering the isthmus could be removed it is probable that even now an island would be produced.

"Brown Island" is 2812 feet high and entirely composed of voleanic rocks. The northern end is comparatively low and flat. Since many patches of rock of a brightred colour occur scattered over it, we may presume that scoria-cones are present. The southern and higher end consists of a single erateriform hill, and around the crater are red vesicular basalt-lavas (605) which have flowed over the sides of the rim. A hornblende-basalt (608, see p. 104) oceurs on the east side at a height of about 2000 feet. This rock dips north at an angle of $63^{\circ}$, and from the fact that it ends abruptly as a cliff there is little doubt that much of the original lava-stream has been removed. On the north side of the crater a sulsidiary peak of landed yellow rock forms a massive hill 500 feet high. The crater is at least half a mile in dianeter, and a small shallow pool about 100 yards long occupies its centre. There is little ice or snow in the crater, the lip of which is about 100 feet above the pond. On the west sicle a white trachytic rock (606) has forced its way through the covering of hasalt-glass, and was found on the erater-lip. On the lower slopes no rock in situ was ohserved, but the whole surface was covered with black smooth loose fragments of basalt (603), like the blatk pebhles at Cape Crozier described on p. 11.

\section{The Dailey Islands.}

A number of conical islands, the Dailey Islands, rise through the floating ice at the head of McNlurdo Sound. They are five in number, and all lie almost on the same east-and-west line. Four of these are small and conical, and not more than a quarter of a mile in diameter. The fifth is perhaps a mile long, half a mile wide, and 200 feet high; it is the only one that is at all easily accessible. It is situated on the western margin of the pinnacled ice* (Fig. 44, p. 79). The specimens collected are all of basaltic rocks of limburgite type (510), but plutonic boulders

\footnotetext{
* Ferrar, Geog. Journ., April 1905, vol. xxv, plate, p. 374.
} 
lie on the surfice and in the small crateriform hollow at the centre of the island. There are one or two dykes which project slightly above the loose scoriareous matter of the general surface.

\section{The Dellbribge Islands.}

These four islands lie three or four miles south-west of the base of Mount Erebus and twelve miles north of Winter Quarters; although the nearest together are two miles apart, they are probably all remints of a once continuous land-mass.

Inaccessible I cland, the most northerly of the gromp, is elongated in an east-andwest direction, and has an almost sheer eliff facing the south. Its north side slopes at alout $40^{\circ}$, and is therefore too steep in places to hold the disintegration-products of the rocks which form its higher peaks. The dimensions of the island are, roughly, length two miles, breatth half a mile, and height 500 feet. Mr. Hodssor collected spceimens here, and tells me that the rocks are mueh eonfused, but generally dip to the north. The specimens include a red vesicular trachytic lava (802), porphyritic basalts (805), yellow trachytes (803), and trachydolerite of intermediate character (804); on the south-east end there are many irregularly bedded chrome-yellow bands. Tent Island is nearly reetangular in plan, and has sides about a mile long. Its greatest height is albout 400 feet, and the highest point is close above the steep north-west cliff. The upper surface of the island slopes to the soutli-east and agrees with the dip of the lava-beds. The lowest rock exposed is a basalt-agglomerate (817) which occupies the lowest 100 feet on the north-west eliff. It is covered by sheets of a vesieular glassy kenyte (463-466), with lenticular porphyritic erystals of felspar, like the rock of Cape Royds. These sheets have a dip of about $20^{\circ}$, are parallel, and are each about 20 feet thick. Razor Back Island is merely a ridge of rock rising 100 feet above the water, Its sides meet to produce a central ridge of which the angle is not much greater than a right angle. The long axis is perhaps half a mile long, and along the same straight line is the Little Raror Back Lsland. The specimens obtained are vesicular lavas of olivine-lasalt $(470,471)$ and of traehytie rocks $(473,476)$. 
Chapter III.

\section{THE MAINLAND OF SOUTH VICTORIA LAND.}

\section{Cape AdAre.}

IT will not be out of place to supply here a few arditional notes on the rocks of Cape Adare, latitude $71^{\circ} \mathrm{S}$. It may be pointed out that the Cape lies at the foot of the gigantie Admiralty Range, and is formed of horizontal sheets of hasalt and hasalt-

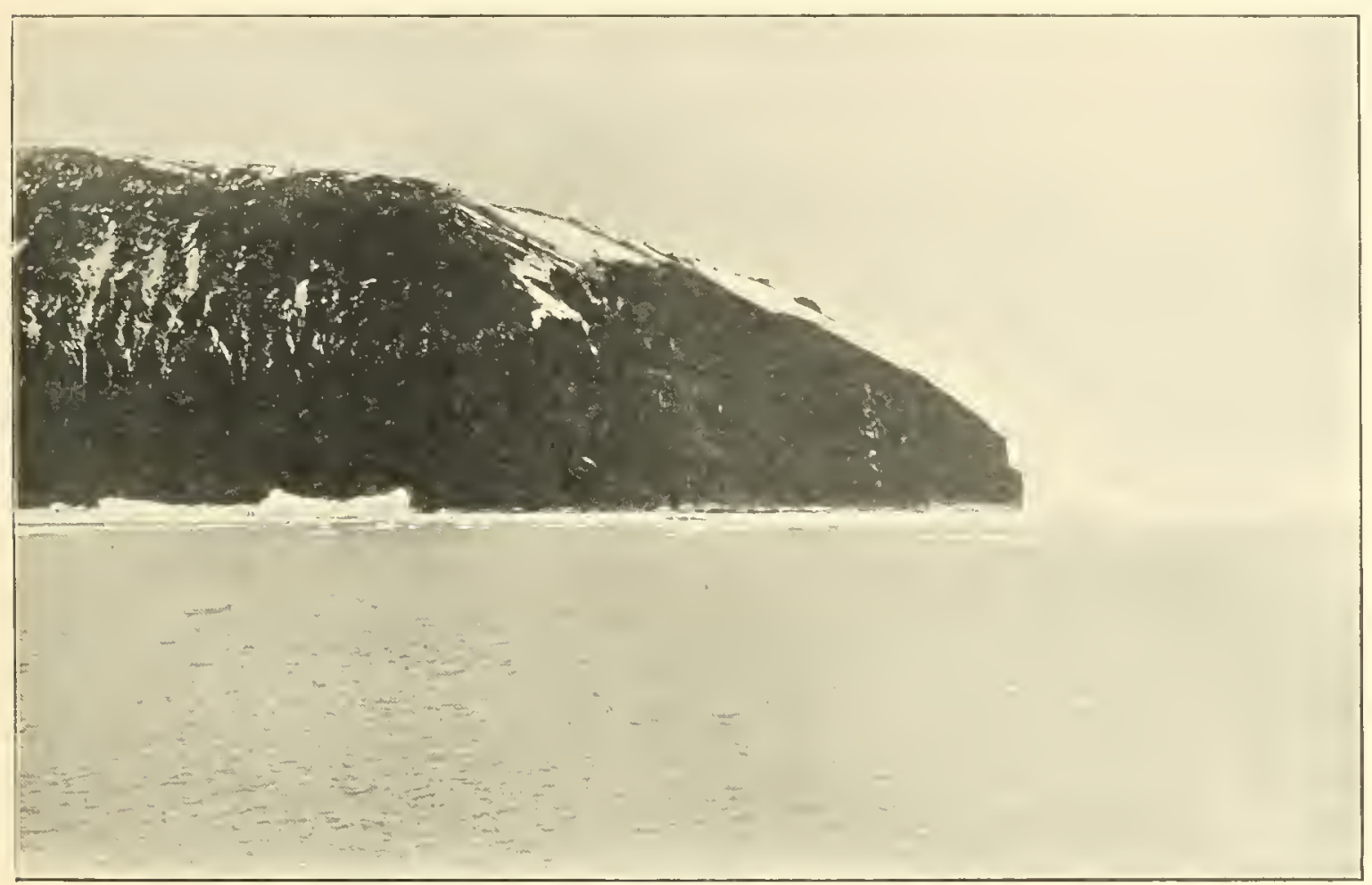

Fig. 6.-Cape Adare Peninsula, from Ross Sea.

agglomerate, similar to those which occur in Couhan Island and perhaps the other islands off the roast.

The peninsula of Cape Adare (Fig. 6) eonsists mainly of nearly horizontal sheets of basaltic lava laid one above another to form a Hat-topperl promontory, which gralually increases in height from north-west to south-east. Dykes occasionally eut across these sheets.* The successive sheets are thimner and more numerous at the nurth-west

* Prior, Rep. 'Southern Cross' Collections (British Museum), 1902, p. 327.

VoL. I. 
extremity, but they become thicker, and are slightly inclined upwards two miles or so towards the south-east. The following sections may be of interest :-

(A) near the north end of the Cape-
Top.
(6) 100 feet-red basalt-rlass (865)
(5) 300 feet-blaek hornblende-basalt (859-86(1)
(4) 50 feet-tuff $(857)$
(3) 100 feet-basalt with vertieal joints (856)
(2) 50 (1 feet-vesicular basalt ( 854 )
Bollom.
(1) 200 feet-talus

(B) about two miles south of the end of the Cape-

Top.

(6) 600 feet--(unexamined)

(5) 100 feet-tuff

(1) 50 feet-boulder-breeeia (54)

(3) 60 feet-blaek olivine-brasalt, weathering into vertical columus (49)

(2) 100 feet-red seoriaeeous basalt (51)

Bottom. (1) 100 feet-seree-slope

This approximately horizontal structure appears to be characteristic of the steep coast line between Cape Adare and Cape Jones, a distance of about 150 miles. This part of the coast is a eliff varying between 1000 and 2000 feet in height. Sometimes antielinal and synelinal folds, whose axes appear to run east-and-west, are seen. Occasional red hands, possibly like those on Coulman Island and Cape Adare, can be distinguished.

\section{The Volcanic Cones on the Mlanland.}

The number of volcanic cones on the mainland is less than las been hitherto supposed, ${ }^{*}$ lut those seen are interesting from their occurrence on what is probably a great line of fault. These cones all rise from the low foothills that form the coast, and the latter is always parallel to the mountain-ranges. The volcanoes, being isolated eones and having as a backgroumd the massive main range, stand out most prominently.

\section{The Summit of Cape Jones (Fig. 7).}

The summit of Cape Jones may be taken as a type of these. The hill near the end of the Cape rises to a height of over 3000 feet, and shows admirably the even convex curves of mountains of accumulation. The whole is covered by a deep pall of snow, which either breaks off at the alge of the high sea-cliff, or blends gradually with the ice-sheet of Lady Newnes Bay. This voleano ocenrs in latitude $73 \frac{1}{2}^{\circ} \mathrm{S}$, longitude $170^{\circ} \mathrm{E}$. It lies to the west of Conlman Island, and on the strip of foothills which is here nearly 20 miles broad. From the north these

$$
\text { * J. W. Gregory, 'Nature,' 1901, rol. 1xiii, p. } 610 .
$$


foothills can be seen to be deereasing slightly in height westwards towards the base of the Admiralty Range, and thus appear to mark off a great longitudinal valley running parallel to the coast.

\section{Cape McCormick.}

On the end of Cape McCormick, latitude $72^{\circ} \mathrm{S}$, there are two bare cones which rise 1000 feet above the sea-cliff. They have crateriform summits which bear a striking resemblance to Crater IIill near the Winter Quarters of the Expedition.

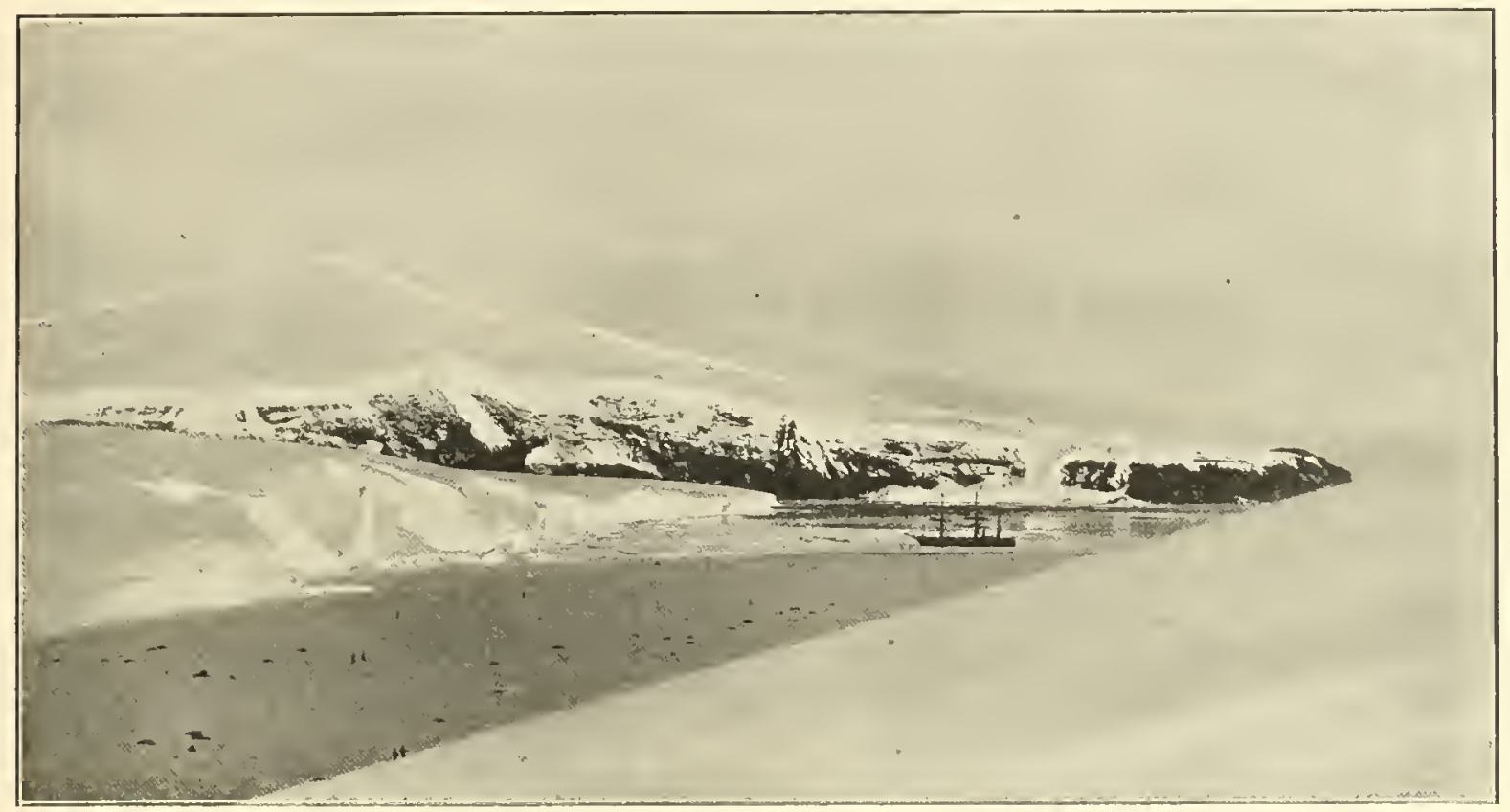

Frg. 7.-A Volcanic Cone' on the Marnland; the Summit of Cape Jones. The 'Discovery' in a gelfy iN the Ladr Newnes "Piediont-afloat."

\section{Mount Brewster.}

Mount Brewster, on the north-east side of Iady Newnes Bay, though it does not attain a great altitude, is noteworthy. The mountain is about 3000 feet high, and rises from the flat lowland at the base of the mountain range. The range with its angular spurs towers above the foothills, and Mount Birewster with even outline rises hut little above the snow-covered land around it. The summit of this hill is slightly flattened, and some part of the crater may still remain.

\section{Mount Melbourne.}

This mountain, 8000 feet in altitude, is situated in latitude $74 \frac{1}{2}^{\circ} \mathrm{S}$., longitude $165^{\circ} \mathrm{E}$., and on three sides rises directly from the sea ; on the fourth side it is joined to a range of higher peaks. The slopes of the mountain are not markedly convex, but 
appear symmetrical from all points of view. The hase is less than 20 miles in dianeter, and the mountain, though 8000 feet ligh, is not nearly so voluminoms as Mount Erehus or Mount Terror.

Basalts* appear to be leveloped at its base, and but few parasitic vents or obrious lava-flows are seen upon its sides. The only specimens brought lack by the 'Discovery' Expedition are rounded pumice-fragments (899). These were obtained from the Hoating ice of Wood Bay, and must have been transported by the wind luring the winter months.

Between Cape Washington and Cape Bernacehi, or in other words hetween Mount Melboume and Nount Evans, no volcanic cone has been noted. This is important when we remember that here the foothills are alssent, and that the coast is straight and uniform for a distance of over 200 miles. South of Cape Bernacehi, foothills composed of gneissic rocks are developed for some 50 miles. These are separated from Mount Morning and Mount Diseovery by the valley of the Koettlitz Glacier, which trends north-west and lies parallel to a line joining the two volcanoes.

\section{Mount Mominy.}

Monnt Norning is a low dome 5759 feet high, and is almost circular. At its base it is 10 miles in diameter. On the south side the mountain slopes down to sea-level, and on the south-west it is separated from the main ranges by low foothills. The Koettlitz Clacier, which opens out north-eastward, occupies part of the above-mentioned depression between foothills and momtain-range. Rarliating lavaHows are a prominent feature of this momtain, but no specimens could be obtained from them.

\section{Hount Thiseotery.}

Mount Discovery, the last voleanie cone which we shall note, is 9085 feet highl, and lies in latitude $78 \frac{1}{2}^{\circ} \mathrm{S}$, longitude $165^{\circ} \mathrm{E}$. (Fig. 32, p. 58). It adjoins Mount Jorning on the west, hut is cnt off from the uearest mainland hy Discovery Gulf, the ice-filler gulf into which the Koettlitz Glacier flows. The momian is symmetrical in outline and has the form of a hell. 'The inflected curves of its sides mite at the summit without indicating the presence of a crater, and they spreat out to give the mountain a circular base, some 15 miles in diameter at sea-level. This nountain was not visited, bnt the moraines stranded in the land-locked bay on its north-east side show that hasaltic fragments are the commonest ejectamentat.

\section{The Minna Bluff:}

The Minna lihuff is a long and narrow promontriry which projects sonth-eastwarl from the foot of Momnt Discovery. It seliom attains a lieight of more than 2000 feet. It is 35 miles long, but its breadth is rarely greater than 5 miles. Its sides are

\footnotetext{
* l'rior, Rep, 'Southern Cross' Collections (British Museum), 1902, p. 322.
} 
very steep and almost parallel, and their wall-like appearanee is unbroken by glacier or ice-eascade. No struetural features are very evident, but specimens of basaltic and phonolitie roeks (619 and 622) obtained from two spots near its south-east end prove its volcanie origin. On the north-eastern extremity there are lava-flows quite like those of the east side of Black Island and of the Harbour Heights, Winter Quarters. The outline is unbroken and therefore it is impossible to say whether this peninsula is composed of lava-sheets, or is a series of scoria-eones like those which make up the Harbour Heights.

\section{The Continental Raygh.}

South Victoria Land, as previously mentioned, consists of a great range of mountains stretching in a north-and-south direction for 800 miles at least, and is apparently the eastern elge of a vast platean, for between latitudes $77^{\circ}$ and $78^{\circ} \mathrm{S}$. Captain ScotT travelled 200 miles westward over a level region having a uniform height of about 7600 feet above the sea.

The lange maintains a miform high level. Any peaks, such as Iount Sabine, that rise to heights of over 10,000 feet do so

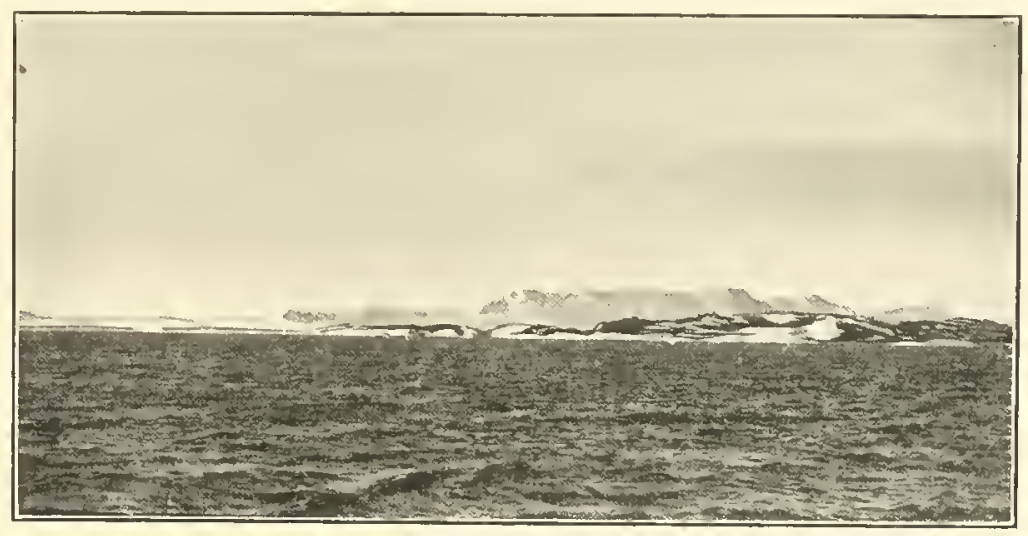

Fig. 8.-Mount Nansen, the tabular mountain south ow Cape ivashington.

from correspondingly high sumoundings, so that there are practically no peaks rising to great altitudes from low levels and towering above the surrounding land. In fact, the land does not show great relief.

Surgeon MoCommok, of H.M.S. 'Enelus,' considered the whole range to be voleanie; but this is obviously not the ease, for all the higher peaks are pyramidal in outhine, and exhibit a house-roof shape which could not have resulted from the eruption of rocks from loeal centres. The Ross Expedition was less fortunate than the 'Disonery,' for the latter was able to steam in close to the land and see the peaks from nearer points of view. Thus, just south of Cape Washington, a tabular mountain, Mount Nansen (Fig. 8), was olserved from the 'Discovery' to have appar'ntly horizontal bedding planes and almost perpendicular searps showing plateau-strueture. The earlier explorers were too far from the land to perceive these characters.

The range, or chain of mountain-ranges, naturally diviles itself into sections or links, and these may be conveniently considered separately.

(1) The area hetween Cape Adare and Cape North, a distance of 100 miles, is 
more snow-eovered than is the land further to the south, and the coast, which is parallel to the monntains, fiares north-east. The monntains here form the main part of the Admiralty Range of Ross. They diminish in altitude as one passes westward to (ape North, and with the decrease in height there is a eorresponding inerease in the proportion of the snow-rovered area. At Cape North itself the eovering of snow is almost minteruptad. Here the peaks which form the horizon are all of the pyramidal type, and they have their easterly shouklers trmueated sharply at the shore. There are no deep valleys, hut the snow often exhilits prominent series of teraces, one aloove another and parallel to the const, and the whole is somewhat suggestive of the existenee of some horizontal structure in the rock heneath.

(2) The liange which orupies the 250 miles of anast hetween Cape Adare and Cape Washington forms the highest, and perhaps the largest, land-mass. This area lies to the sonth of area (1), the Cape North portion, and is contimmons with it. In the south its line of peaks receles so far from the const that the ronnection between this ares and the third, or Prinee Albert, seetion is not yet known. Here one sees the possibility of a division into two distinct geological areas, for low foothills are almost antinuons along the whole length of the coast from the Cape Arare promontory to cape Sibbald or even Cape Washington itself". Behind these foothills there appears to be a depression, which takes the form of a series of valleys rumning north-and-sonth, and hehind the depression is a wall, or possilly a fault-face or escarpment, whirh rises to heights of 10,000 feet, and has weathered into a series of fine pyramidal poiks.

Many photographs ilhsstrate the form of the range, and some show peals, such at Momt Minto and Jount dilam, whith rise as enomoms gathles from a platean ahrady ligh, and thus do not greatly overshadow the smrommling monntims.

At the head of Rohertson Bay the depression at the font of the mountains resolves itself into a valley, and even the bay itself may he considered a contimation of this. On the south side of Mount Methomme this depression is again prominent; here it resolves itself into a valley rmming out to the south-east, and having the volcano (Nomnt, Melhourne) as a part of its left bank, affording evidence that the monntain is situated upon a line of fanlt.

(3) The Prince Albert Mountains, 200 miles in length and trending due north and sonth, is the lowest large area of land seen lyy the Expedition. This range is important, not only beranse it is practically new, hut because of its extreme uniformity of rhanater. It is highest at the north end, where Monnt Nansen, mentioned above, rises to 8788 feet, is lowest about the centre, latitude $76^{\circ} \mathrm{S}$., where it is only about 3500 foet ( 11 onnt George Nurray, 3591 feet), and rises again to 8000 feet (Iorse-

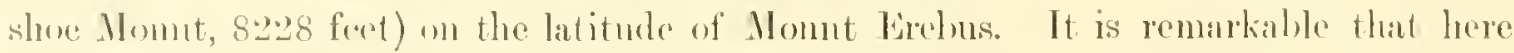
the antern lorder is always steep and gives one the impression that it is only the outlying chlge of some greit plateau from which streams of ice come down between 
the munataks. Iater, when the former extent of the Beacon Sandstone Formation is considered, it will be seen that this uniformity of landseape is not smprising.

(4) The Royal Society Range has a length of some 50 miles; this length is almost bisected by the 78th parallel of latitude, and is the only part of Sonth Victoria Land which has been examined in detail. In the main all the structures observed in the Admiralty Range are again seen, but are much more strikingly developed (Fig. 9). There are foothills of insignificant height, a north-and-south valley separating the foothills from the main mountain-mass, and a mountain-mass

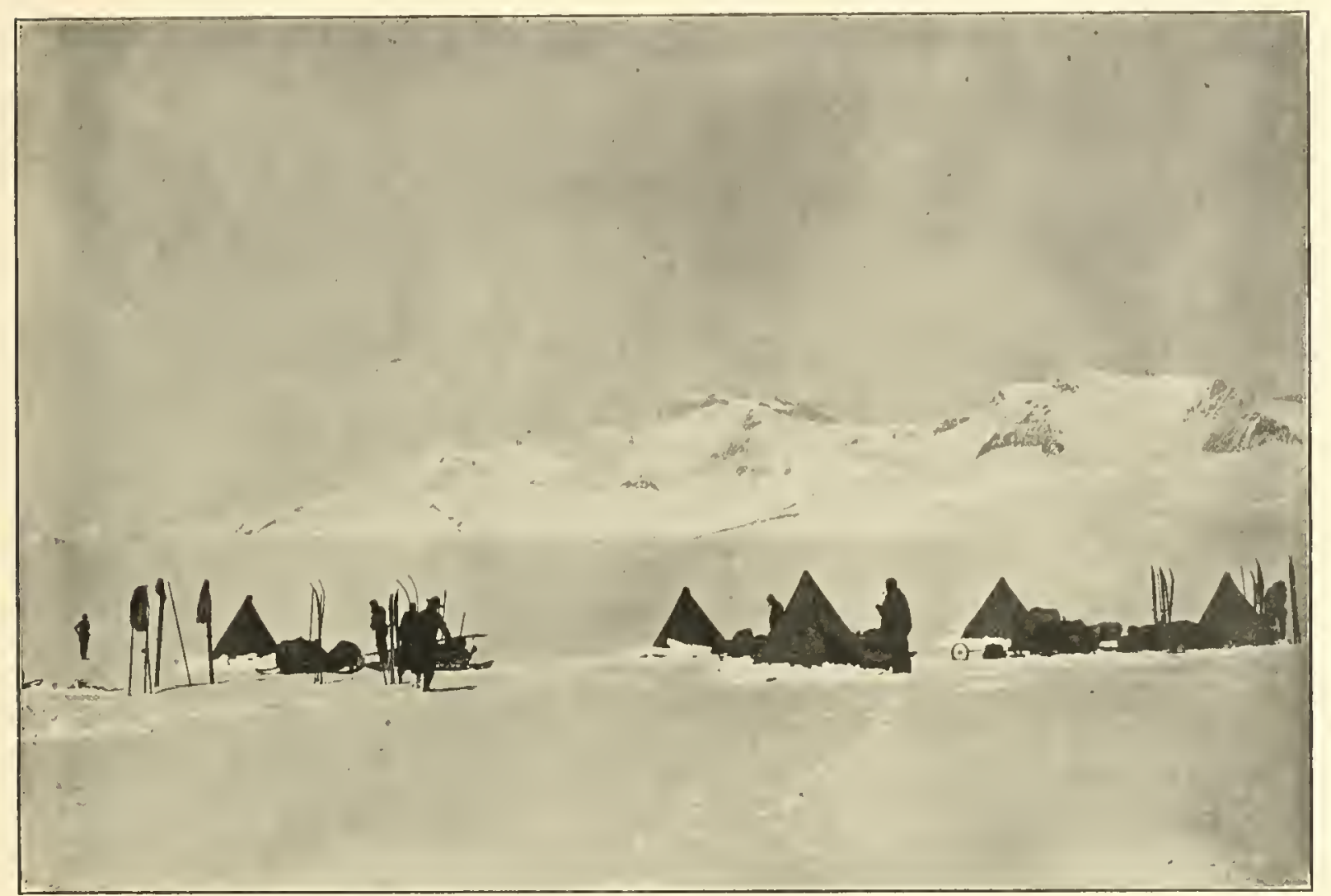

Frg. 9.-Mount Huggins and thie Royai, Sochety liancile.

rising in a uniform aliff behind to a height of 10,000 feet and having ondeasional peaks over 12,000 feet in altitude.

From our Winter Quarters this range conld always he seen, though quite 50 miles away; and so clear was the atmosphere that, even at this great distance, the plateau-form was always evident and was rendered still more striking by the hroad band of lighter-colomed rock below. This band must be at leist 2000 fect thick; it is apparently berlded horizontally and extends from end to end of the range. The peaks rising alove the plateau ale of darker-eolomed rork and in strong contrast with it.

Thus, the form of the range appears to be deternined by the horizontality 
H. T. FERRAR.

of the rocks which compose it, a charaeter aloundantly proved by the slerge-parties who passer along the leep glacier-filled valleys that eross it eastward to the sea.

(5) 'The four separate ranges which determine the 300 miles of almost straight mast to the sunth of latiturle $79^{\circ} \mathrm{S}$. appear to he exactly similar to those alrearly consilleded, and mity he dismissed with the mention of the plateau-character which is strikingly shown and beantifully illustrated by Dr. WiLsox's sketehes, made luring the great journey to the south, when Captain Scott, Lientenant SHacklexox, and Dr. WILson reacherl latitude $82^{\circ} 16^{\prime} 33^{\prime \prime} \mathrm{S}$. These sketches are all the more valuable in that they were made by an unprejudiced observer.

Each of the four ranges averages 8000 feet in height; they are separated by wide channels far below the level of the plateanx, and such channels, having straight aud exceediugly steep sides, appear to he typical features in the geography of all south Victorian mountain langes.

\section{Rine Edwari Vll Jaxil} (Fig. 10).

This lame lies at the eastern end of the (ireat Ice Barrier of lioss, and is, therefore, comnerted with the

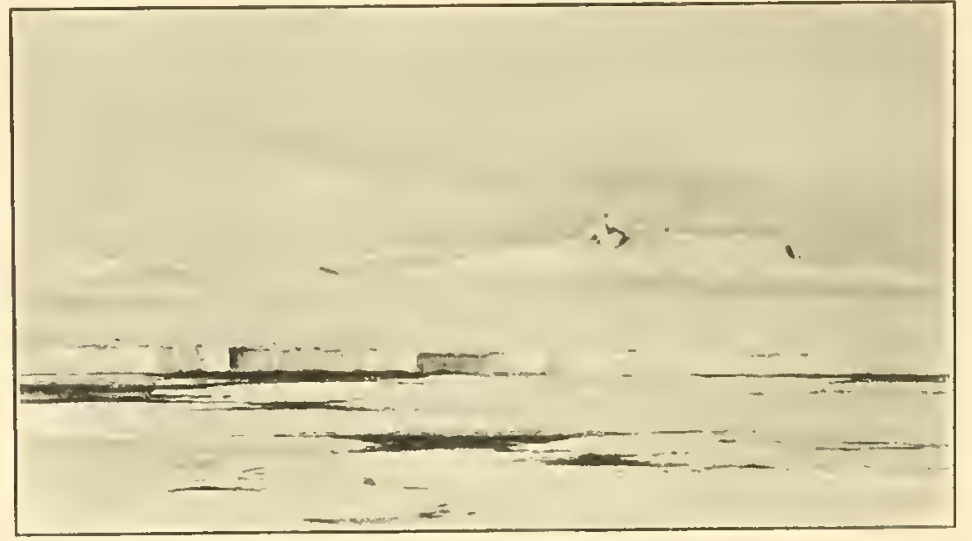

Fig. 10.- King Edward Vil Land. mainland by ice at least.

It lies hetween latiturles $76^{\circ}$ and $78^{\circ} \mathrm{S}$, and longitudes $148^{\circ}$ and $160^{\circ} \mathrm{W}$. It rises 2000 to 3000 feet high and is almost wholly snow-covered. The coast trends X.E.-aud-S.W., and appears to he banked with low foothills completely covered with snow. It cousists of two parts: (1) an isolated headland, some 1500 feet high and 10 miles long, stamling well lefore (2) which, except for the low amd isolated peak at the north-east end, is smooth ant tabular, but is rompletely snow-covered. The two areas ale siparated ly a comparatively low snow-covered depression.

The headland is mosymmetrieal in shape and has a steep cliff on its north side; at three places, where too steep to hold the snow, there are good rockexposures. The laud was not visited, hut sperimens obtained from a dredge-haul $(256-258)$ and from two icelergs consist of granites and gueisses and not of volcanic rocks. As the current is sonth-west along the coast, the rocks dredged up cannot have been camied far; it is also quite improbable that the irehergs can have travellod any gireat distance. 


\section{Chapter IV.}

\section{TIIE GNEISSIC ROCKS AND CRYSTALLINE LIMESTONE.}

As the gneissic rochs occur at sea-level at the foot of the highest part of the Royal Society Range, and as they are fomd in the Range helow a sequence of rocks which is 12,000 feet thick, they may be safely regarded as forming the ancient platform on which the central part of South Victoria Land is built. Ahove the gneisses, come successively, over a very large area, granites, sandstones and dolerites. Little is known of the field-relations of these except the order in which the rocks oecur: The important deposit of sandstone provides a convenient stratigraphical datum-line, with reference to which the positions of the other rocks will be considered. The above order seems, howerer, to he ehronological, for', where the jumetions between any two rocks were examined, the lower rock nsually appeared to be the ohler. With regard to the gneissic series, the localities at which they lave heen examined may be monidered in three groups:--

(1) The Foothills of the Royal Society Range.

(2) The Knkri Hills.

(:) The C'athectral Porks.

\section{The Southers Foothills (Fig. 11).}

\section{South Sile of the Blue Glacier.}

On the hill $\mathrm{J}_{1}$, 5400 feet high and 15 miles from the sea, occur masses of crystalline limestone which rise at least 1000 feet ahove the snow. The limestone is almost pure white, and the constituent erystals are often an eighth of an inch across. It becomes so crumbly, on weathering, that it is aifficult to get a hand-specimen from the rounded surfaces that are exposed.

The rock (568) has important structural planes which dip at $70^{\circ}$ to the east, while the strike is north-and-south. The hill appears to be wholly composed of limestone; its western slope is very straight and steep, and is suggestive of a fault. Parallel to the bedding-planes or, more probably, joint-planes are bands of a dark fine-grained hormblende-biotite-granite (569) from 4 inches to 2 feet in thickness and about 50 yards apart. At this spot there were no obvious metamorphic features near the junction of the two rocks.

* For localities indicated by letters, see the map of the district near the 'Discovery' Winter Quarters, and the sections in Plate VII. 
The south ond of the Froothills.

Before leaving the discussion of this locality, mention must be mate of the sperimens lnought bark by Dr. WILson from 30 miles further south, elose hy the ketulitz Glacier. From the specimens themsetves $(834-853)$ and from what he has reported aldout their oecurrence in the fieht, it would appear that the fionthills are compresed of the rockis of the metamorphic series.

\section{Bume Inlet. Latitude $80^{\circ}$ S. Longitude I $1 \mathrm{I}^{\circ}$ E. (about).}

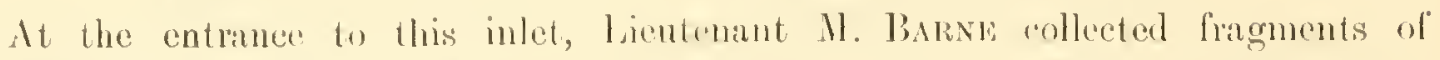
glanitr, gneiss and mica-schist (7.34) from a seattered momine. 'l'hese fraguents must

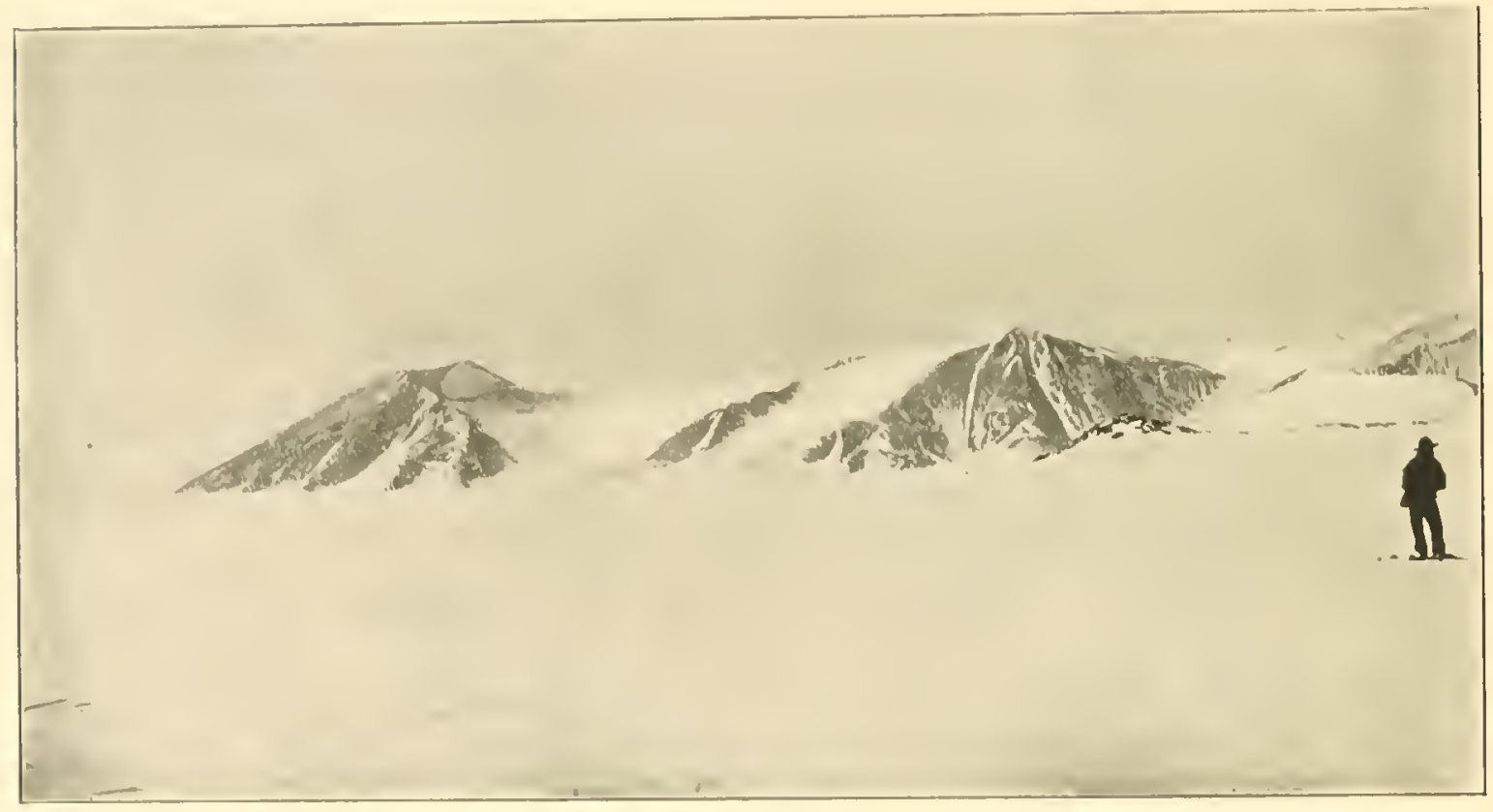

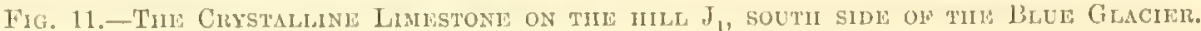

have leen derived from the mass of hand lying south of the inlet and quite 170 miles sonth of the Blue Giacier.

\section{T'HF NorTHER FoothILAs.}

The Northem Foothills oceupy an almost rontungular ane:a alout 12 miles long and 10 miles broat. The Northern foothills are separated from the sontlen Findlitls by the blue Glacion, which orenpies in deep and rather sterp-sided valley from 5 to (j miles across. They appear to be manly composed of arystalline linestone.

The west side of the foothills, one the north side of the bitur Glaction.

'T'wo miles north of $C_{4}$, the limestone is simital to that of $J_{1}$, $f$ miles distint (Fig. 12). Here, however, the hominat stmetnre-planes strike N.S.L.-S.S.W., 
and dark veins of a doleritic rock (566) make an angle of about $30^{\circ}$ with them. From the floor of the Snow Valley, the snow sloped steeply up to the rockface at an inclination which was too great for 11 s to get the slerlges 11 . Laving these at the bottom of the slope for a couple of hours, a very risky proceeding when no landmirks are available, we obtained speemens without mishap. The fault-face on the Northern Foothills is more olvious than on the Southern; it is brought into prominenee loy the fine, lare and apparently glaciated peak (s), which rises over 4000 feet hight.

\section{Malf-uray down the Blue Glacior.}

Working down the Blue Gilicier, Dr. Kontwitz collected somewhat similar specimens from a hill 5 miles east of $G_{t}$; here, as nearel $G_{i}$, the bedding-planes dip to the E.S.E., and the dark reins cut across the strike to the E.N.E. On this hill one of the structure-lines is remarkally prominent and suggests a thrustplane, but no difference in the chanacters of the rocks on the opposite sides of the line wis olvious to the naked eye. The specimens anllected by lir. liostrutiz in this neighbourhood include dioritic dyke-rorks (572, 574) and a scilist (570).

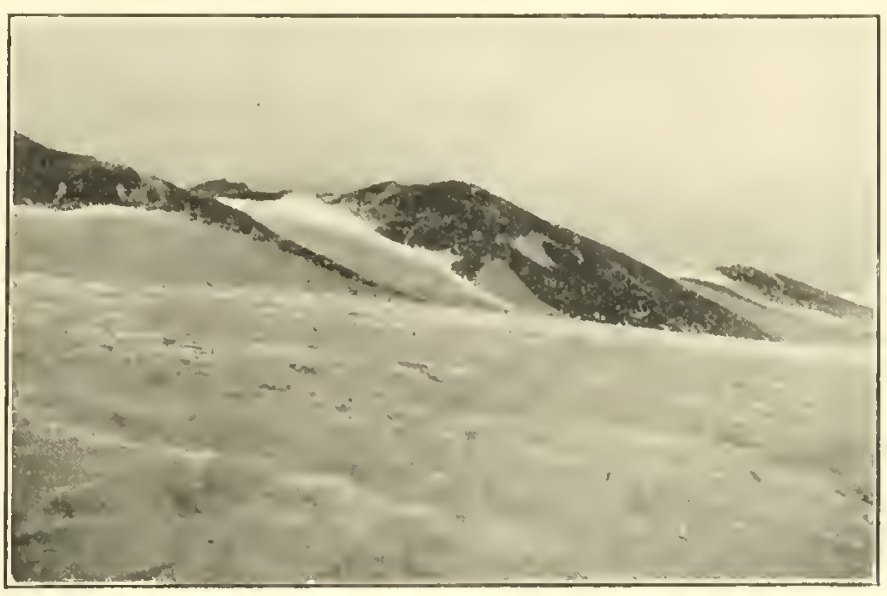

Fig. 12,-The Crustalline Limestone on tine nortil side on THE BLUE GLACIER, AT $\mathrm{G}_{4}$.

\section{The north-east end of the Blue Gilacier.}

At $G_{1}$, the most south-eastern of the Northern Foothills, the arrangement of the roeks is well seen from a distance. Here, however, the rock is so planed down by ice-action that the rapid alteruations of dark dyke-roeks and light-eolonred limestone are rendered evilent. 'The dykes crossing the brow of the hill are plainly visible from the glacier. A dylie of kersantite (579, see p. 130), 20 yards wirle, cuts the erystalline limestone $(575,576)$. The hill is 4000 feet high; the snow wraps its base and reaches quite up to the 1000-foot eontour. Here again the sledges had to be left more than a mile away from the exposure. On this oecasion, owing to the snowstorm that began during our absenee, they were diffieult to find when we returned.

The right bank of the Ferrol Cilacier, between $\mathrm{G}_{2}$ and $\mathrm{G}_{3}$ (Plate IV).

The Northern Foothills, as stated above, form a rectangular mass with the north side some 12 miles long, forming the terminal portion of the right bank of the Ferral 
CHacier. The hill $\mathrm{G}_{2}$ occurs at the north-west corner and sends ont a shoulder four miles to the west. This shoulder is cut off from the granite-hills, $\mathrm{G}_{3}$, by al glacicr which flows northward out of the Snow Talley. The shoulder runs out as a narrow promontory along the same line as the north edge of the foothills, and rarely rives much more than about 1000 feet. The tributary glacier flowing north causes an inconvenient belt of hummocks two miles in width, and it is not till a height of 700 feet has been aseented that rock is found in situ. The slope of the hill makes an angle of between $30^{\circ}$ and $40^{\circ}$ to the horizontal, and is covered with loose morainie matter ; lut at a height of 700 fent a erag of gneiss (729) appears. The rock is dark,

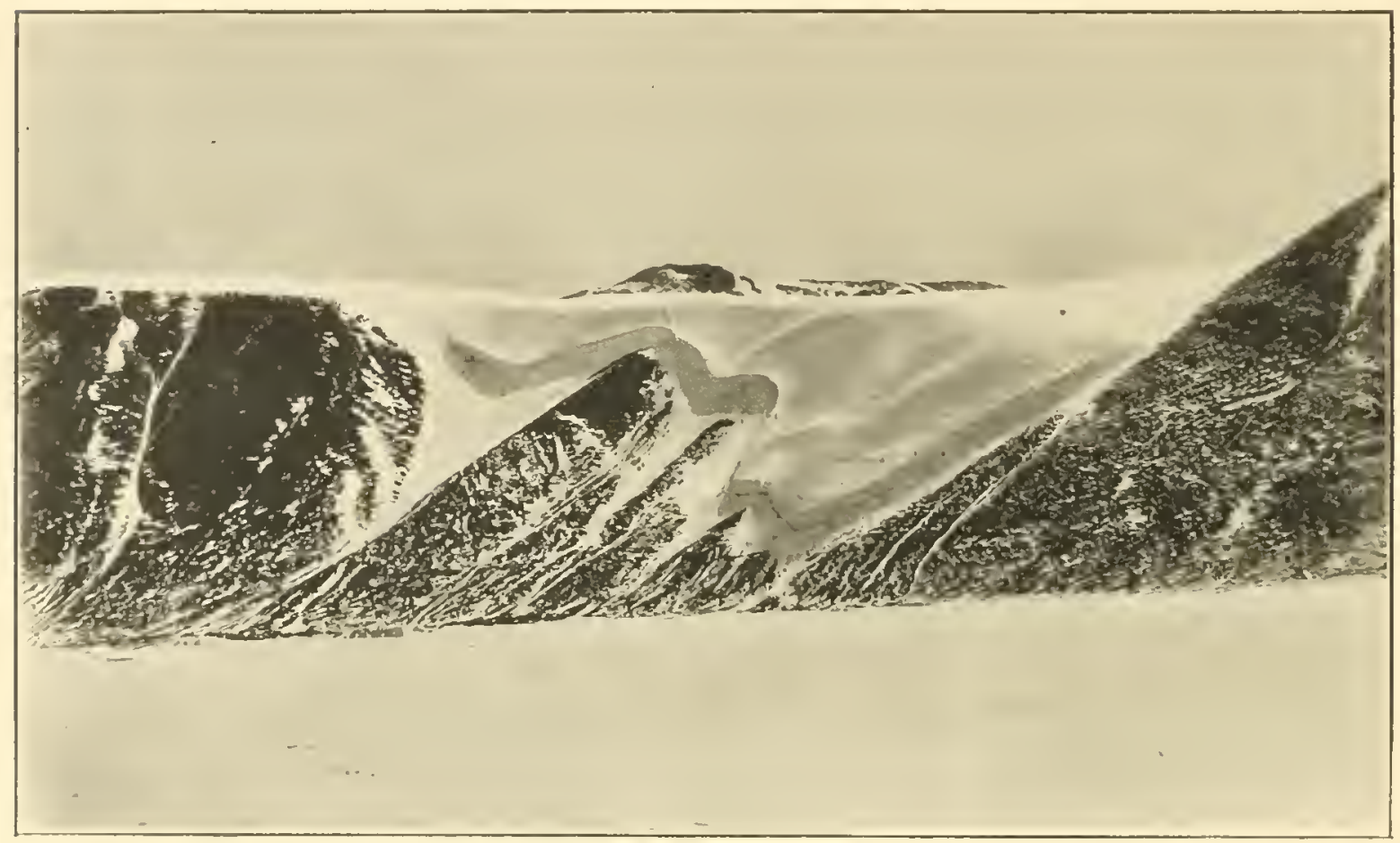

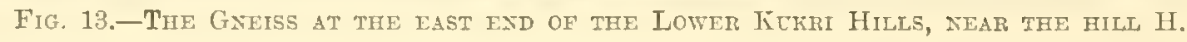

fine-graincd, and very streaky. The foliation dips to the south-west at an angle of $60^{\circ}$, a faet of some importanee, as we shall see when we consider the Kukri Hills.

The KuKRI HiLLs.

This name has heen given to the hills lying immediately north of the Ferrar Glacier, as in plan they lave the outline of that implement. They separate the North Fork from the East Fork, and are themselves divided, hoth topographieally and geologically, just at that point where the Ferrar Glacier floats off into its dleep ford-like chammel. 'T'he western and higher part inchules all hills lenoted hy the letter. D on the map; while the eastem and lower part is lefined hy the hills $m$ and $\mathrm{I}$, at its western and eastern extremities, respectirely. 
The Eastern or Lower Kukri Hills hardly rise above 3000 feet, but maintain this height most uniformly over the whole of their length between $m$ and $H$, a distance of 15 miles. These hills form a narrow promontory al rout two miles in breadth with steep, sometimes almost vertical, sides. They lie sir miles or so north of the Northern Foothills.

\section{New IJarlour Iteiglut (II) (Fig. 13).}

At the extreme castern foot of the hill $\mathrm{H}$, or New Harbour Height, specimens $(730,731)$ of hornhlende-sehist and gneiss were obtained. The gneiss belongs to the dark variety, the strueture-lines dipping at an angle of $30^{\circ}$ to the north-east. About

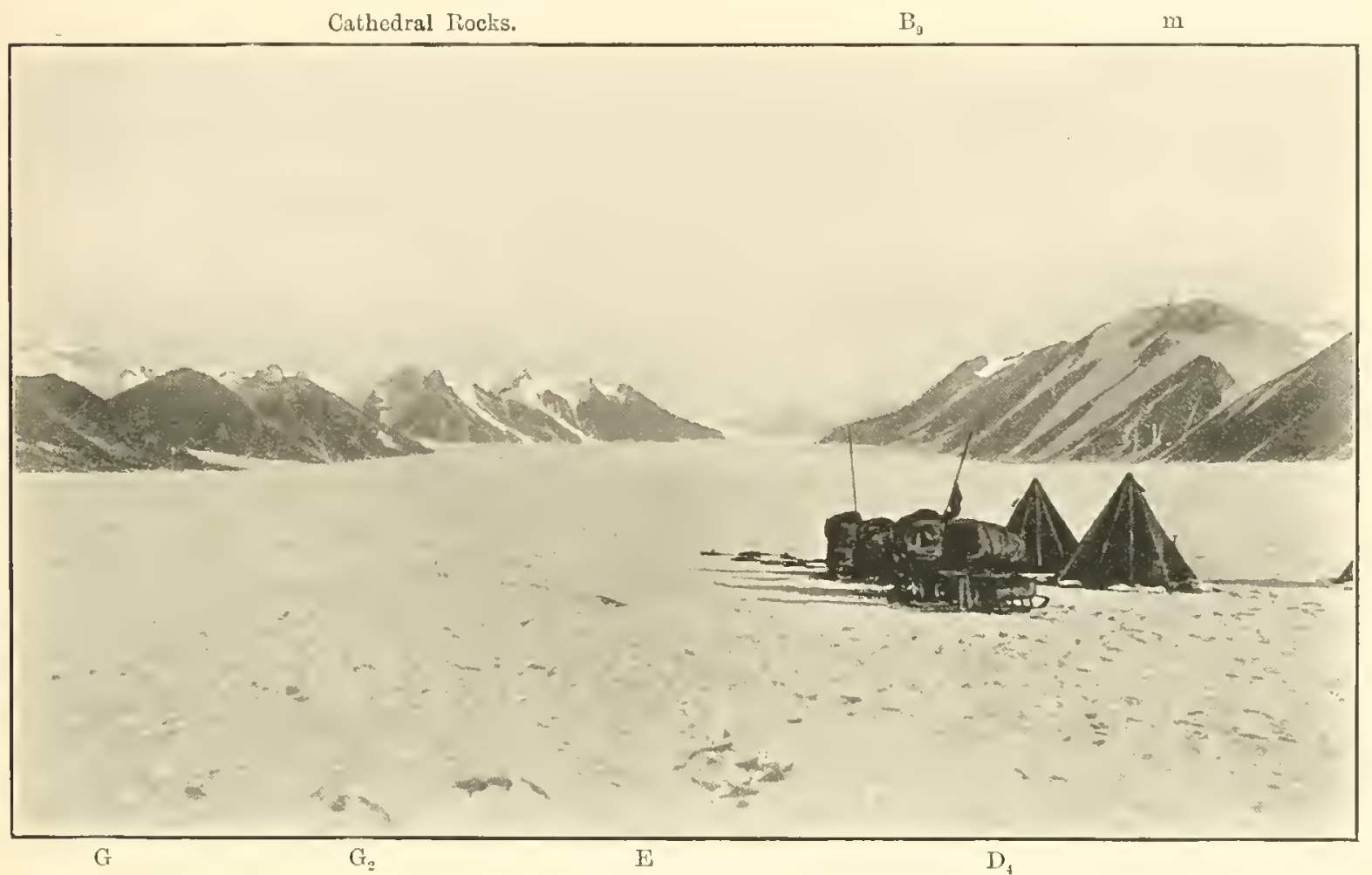

Fig. 14.-Looking up the Ferrar Glacier, Northers Foothills on the left, Cathedral Rochs near the centre, and the Kukri Hills on the rigut.

a mile west of this point, where a small hanging glacier on the south side of the hill occurs, the dip suddenly ehanges to one of $20^{\circ}$ to the west. The dip is emphasised hy the fact that the snow always lies only in sheltered hollows. The hanging glacier lies on what appears to be a fault.

\section{Below the hill $\mathrm{D}_{\text {s. }}$}

Below $m$ at the westem end of the Lower Kukri ILills a white crystalline limestone oceurs, and the bedding-planes of this rock dip to the north-east at $70^{\circ}$. The apparent thickness is about 1000 feet, and the strike is N.W.-S.E. Between this white 
limestone and the dark foliated gneiss at the east end, a long stretch of the valleyside appears to be gneiss with foliation-planes dipping to the west, and therefore to agree with that met with on the south sirle of the valley near $G_{2}$ (Fig. 14). The white limestone (728) abuts upon a grey augen-gneiss (727), but the actual junction couk not be examined as a hanging glacier lay upon it. The augen-gneiss appears to he part of the great mass which iorms the lower and greater part of the hill and rises to quite $\$ 000$ feet.

\section{Below $\mathrm{H}_{2}$.}

At Cape Bernacehi, 20 miles north of the Northern Fonthills, the rock composing the hill $\mathrm{II}_{2}$ has apparently the same structure as that of New Iarbour IJeight, or the hill II, while the elongate hill $h_{4}$ is a replica of the portion between II and $\mathrm{m}$, and has structural planes dipping to the west. The roeks were not examined at this spot, but the serrated outline and the trend of the snow-water channels point to the structural lines heing exartly parallel to those on the Lower Kuliri Hills.

\section{The Cathlidral Rocks.}

These rorks lie 40 miles from the contst, and rise to heights of over 6000 fcet. The ghacicr-surface at their base is alout 1500 feet ahove sea-level, and the summits of the Royal Soricty Range, of which the Cathedral Rocks are the northern extremity, rise to altitudes of over 12,000 feet directly behind them. The cathedral Rocks slope steeply down to the Ferrar Glacicr, and form its right bank for a distance of 10 miles. They form three of the shoulders of the range just mentioned, and are separated by trihutary glaciers which run out northward along narrow ant steep-sided valleys. These shoulders projeet as arites from the main plateau of the Royal Society Range. They are eomposed of gneiss, granite and dolerite, and may he topped by small outliers of sandstone (Plate III and Seetion II, Plate VII).

There is an exposure of gneiss at the foot of the eentral shoulder, which is resignated $\mathrm{E}_{2}$ on the map. This exposure rises 500 and 600 feet above the ice (Plate IV). The line dividing it from the granite is very sharp, and can be followed for a distance of some 3 miles along the glneier. On the west it is hidden by a sudden rise of the surface of the ice, and on the east is eut off by a hoss of diorite (715), which appears to have burst through from below.

The diorite forms the eastward half of this shoulder as well as the whole lower portion of the eastern shoulder $E_{1}$. The gneiss is overlain by a sheet of pink granite, which, onee known, is easily recognisable at a distance by the faet that the latter forms serees, whereas the former produces a cliff. 'The npper surface of the gneiss is a well-marked mululating line, cut off short on the east where it meets the diorite. In certain other places several much smaller dylies transgressing the gneiss were observed. Of these dylies some are grey gratuite and 
some are pink granite, and both kinds are more abundant towards the eastern end of the exposure. Here the pink roek displays augen-structure (716), and oceasional isolated patches and wisps of the ordinary foliated gneiss were observed in the middle of the masses of augen-rock. The dykes form a rough network over the face of the gneiss, and their thicknesses vary from 6 inches to 12 feet. The most prominent consists of a pink quartz-porphyry (709), cutting through the gneiss perpendicularly to the foliation. The gneiss here is dark in colour, and its alternating lamine are usually under a quarter of an incl in thickness. These foliations are themselves folded into series of anticlinal or isoclinal folds, with amplitudes of about 8 feet, the various bands remaining parallel.

Other specimens from later veins or dykes traversing the augen-rock may be mentioned, namely :-

(1) A green actinolite-rock $(725)$.

(2) A white pegmatite-vein (723).

(3) A thin seam containing mica-plates up to half-an-inch across. 


\section{C'Hapter T.}

\section{THE GRANITES.}

Thougr granitie rocks lad not been found in situ in the Ross Sea area, the frequency with which fragments had been dredged up ly the various ships proved, if not a wile distribution, at any rate a great loeal development of this kind of rock in the area undel consideration. If we neglect the oceurrence in moraines such as those found on the basaltic peninsula of Cape Adare or on the slopes of the volcano

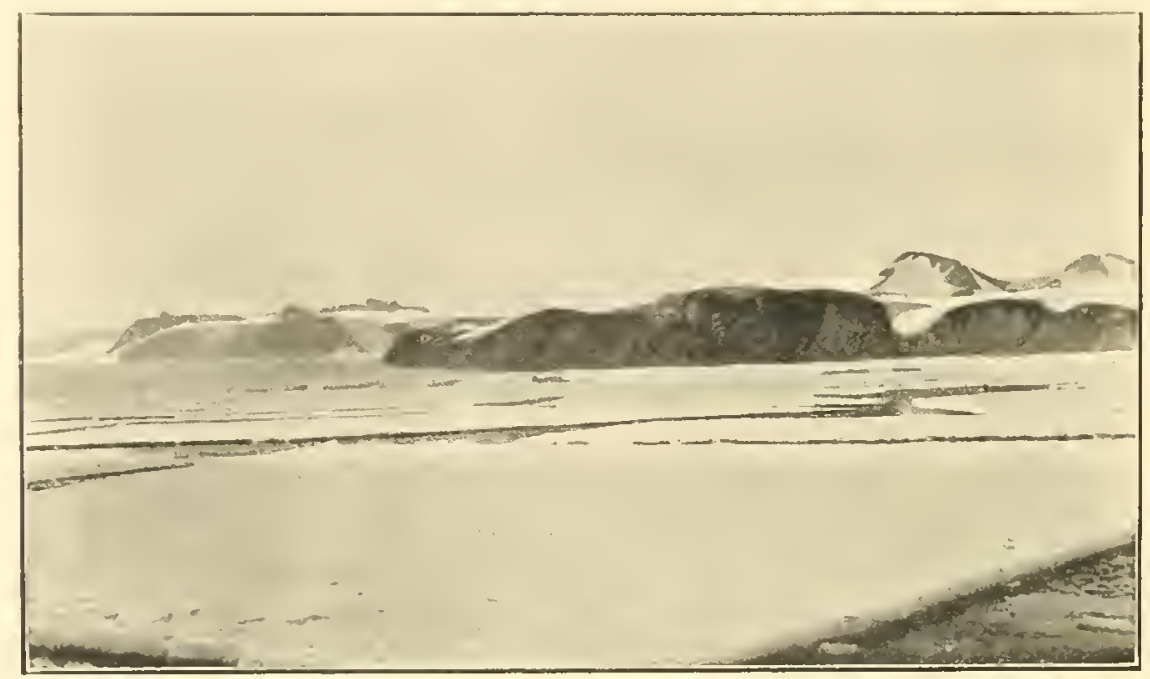

Fia. 15.-Dolemite uron Granite on tile nortil sidx of Grantte Harbour.

Iount Terror, there are two localities where granite has aetually been found in place. At the first, which has been ealled Granite IIarbour, in latitude $77^{\circ}$ S., the granite abounds; though no other rock could be examined in the time available, a darti rock was secn capping the granite (Fig. 15); that this is dolerite is almost certainly proved by the plateau-like form of the hills on the side of the harbour remote from our landing-place, and by the finding of dolerite-fragments on the scree-slopes (see p. 54). The second locality is the Royal Society Range; here the granite has heen examined at several spots over a distance of some 20 miles, and appears to ocrupy an area of quite 200 square miles. This district may conveniently be subdivided into two areas-(1) the Snow Valley west of the Northern Fothills, where the granite occurs in isolated hills, and no other kind of rock has been seen; (2) on the two sides of the Ferrar Glacier, where granite, and its relations to the rocks both above and below, have been examined. 


\section{Granite Harbodr (Fig. 15).}

In this harbour there is a prominent headland some 500 feet high and two miles long; in form it is distinctly like a bursting cabbage. Where a landing was made the rock proved to be entirely granite. The rock-surface is absolutely bare of snow, and is weathering under desert-ronditions apparently anulogous to those deseribed l,y WALTHER as obtaining in Sinai." The joints tend to be platy aud parallel to the surface, but the edges of the joint-lolocks are ragged, and the curve is usually convex downwards. In other places the joints are vertical; there the rock breaks up more rapidly, and prolnees talus-slopes which cxtem almost the whole height of the cliff-face. Dark circular pateles, in rows which are often parallel to the joint-planes, are seen on the surface, and it came as a surprise to find that the rock is eoarsely crystalline.

The greater portion of the boss consists of a grey biotite-granite (129), and the larger talus-slopes always follow certain veins or dykes which extend up the whole face of the cliff. The centres of these veins consist of a coarse pink granitic rock (155) with idiomorphic crystals of red orthoclase up to half an incl in diameter, but within a distance of some fifteen feet these phenoerysts become paler in colour, the rock meanwhile hecoming less porphyritic, and thirty fect from the centre it has graded into the ordinary grey granite of the main mass of the hoss. These pink dykes are about one hundred yards apart; it is noteworthy that in many ases the change from grey to pink is not quite gradual, but takes place in stages at the joint-planes, thus suggesting multiple dykes. These stages of the passage are marked by bands, a foot or so across, which become successively coarser and pinker as one passes from the sides towards the centre.

Thin scams of micaceous schist (96), narrow black basalt-dykes (113), and numerous other varietics of rock, were met with, and specimens of these were collected during our hasty scramlle ashore (see p. 126).

\section{The SNow Y'alley west of the Northers Foothills.}

In the area between the Foothills and the Royal Society Range, a district which I have called the Snow Talley, isolated hills just raise their heads above the snow, and expose to view occasional masses of granite-blocks, which at first sight would appear not to be in situ. There are five or six of such hillocks, with summits about 3500 feet above sea-level, which form the watershed between the Blue Glacier and the ice-cascade separating the hill $\mathrm{G}_{2}$ from the hill $\mathrm{G}_{3}$.

The points $\eta_{1}, \eta_{2}$, ete, on the map indicate the positions of these hillocks, but of the four only $\eta_{2}$ was visited; it proves to consist of grey hornllende-hiotitegranite $(561,562)$. The mass exposed is about 100 yards long, and rises 200 feet 
ahove the snow which surrounds it. When traced from rest to east the rock heromes finer grained. In places it eneloses many vertical quartz-veins (560).

Near $\mathrm{E}_{4}$, at a lieight of 5000 feet, Mr. SkELTox obtained a specimen of grey granite (626), and another from a boss of rock just peeping alove the snow. In this exposure the joint-planes dip to the south, and, in places, kersantite-reins (625) ('oss the mass,

From the "3500 feet Knoll," $e_{5}$, Mr. Skeitos linought back a specimen of a somewhat coarse-grained pink granite with phenocrysts of felspar up to a quarter of an inch across $(555,556)$. The exposure is much weathered, and it is liere that the type (A) of hollowed rock* with

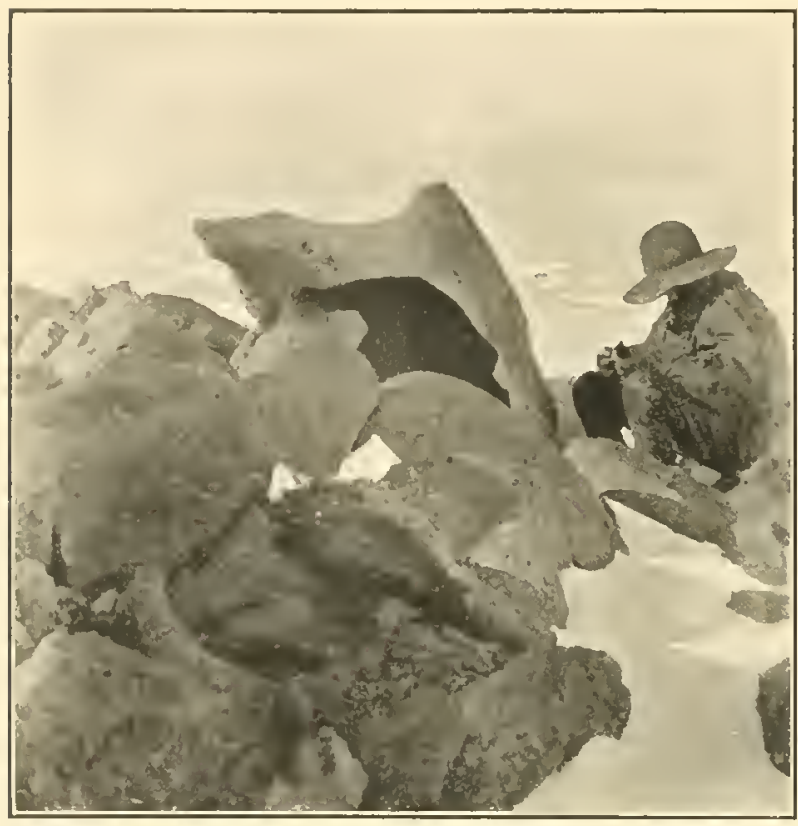

Fig. 16.-Horlowed Graxite-Boctider in the Sxow Vallex near the Royal Society Range. the white (alcium carbonate) incrustation (554) occurs (Fig. 16). This will be referred to later (see p. 88).

At $P_{6}$ Dr. Koeftrtitz got a specimen of dark grey hormblende-granite (563) with idiomorphic crystals of pink felspar up to one inch in length. The height at which this exposure occurs is more than 3000 feet, and the rock forms the eastern end of a spur of the Royal Society Range. The joint-surfaces are conspieuously developed, and are arranged as a syneline with east-and-west axis. Other speeimens from this loeality are a grey hiotite-augen-gneiss (564) and a doleritic rock (565).

The Grante Hillos between $G_{2}$ axi) $G_{3}$ (Plate IV).

The hill $\mathrm{C}_{3}$ rises to a height of 3500 feet above sea-level; it is 1000 feet above the level of the Snow Valley, and nearly 2000 feet above the ice in the valley lelow. Eastwarls the height decreases to 2000 feet, where this patch of liare rock is separated from the gneiss of $\mathrm{G}_{2}$ by the ice-nascade previously mentioned. As a whole this $\mathrm{G}_{3}$ block is a series of rounded hills; as viewer from the surface of the Ferrar Glacier (Fig. 43, p. 78), it has no very conspicuous valleys, lut presents an almost straight and even valley-wall.

The specinens $(557,558)$ from near the summit of $G_{3}$ are all of hornlilentegranite with large pink porphyritic erystals of orthoclase. It is here that type B of lobllowed crystalline rock is found, and owing to the rapid weathering the ground 
around is covered with large loose fragments of felspar. At the foot of $\mathrm{G}_{3}, 1500$ fect above sea-level, the felspars in the rock are even larger than those on the summit, and a dark dyke (714) (sec P. 131) with phenocrysts of homblende up to two inches long is cxposed a few feet ahore the ice. In addition, below this "dark dyke," there is a green band of a fine-grained rock (732) ahout five feet thick. The dark lyke produces a dark patch on the hillside, which, owing to the contrast, can be seen at least 10 miles away. On the opposite sile of the glacier, above $d_{3}$, there are three or four similar patches which, though larger, are probably due to a similar oceurrence of dykes.

The Cathengal liocks.

These rocks aheady reforred to (sce p. 30) form a very imposing triple healland on the south side of the Ferrar Clacier, and are as important as they are picturescue, for here, there seems no doult, is of contained the whole history of the Royal Society Range. At the base, as already stated, is banded gneiss. Above it, and divided sharply from it, is the granite, which must be about 4000 feet thick. Alove the granite is a shect of dolerite, which is rentered conspicuous by its weathering back faster than the granite and leaving a prominent lcdge. Upon the dark doleritesheet is a yellow cap, presumably of sandstone, which forms the summits of all three headlandis (Fig. 17). (See Scetions 1 and II, Plate VII.) 
It the foot of $E_{2}$, dykes of fine-grained pink (711) and grey (710) granite force their way into the gneiss and blend with the sheet of granite. East of the shoulder $\mathrm{E}_{2}$, a tongue of granitie rock ends the gneissic exposure, as if here loursting through from below. At the edge this tongue is mainly pink in colour, and occasionally there are large patches of almost pure pink-felspar-rock in it. W'hen traced eastward it passes into a diorite, becoming gradually darker in colour (715) and coarser in texture, while well-formed black erystals of hornblende appear and increase in size up to a quarter of an inch in diameter.

The relation of this rock to the granite making up the hill $\mathrm{G}_{3}$ eannot be traced owing to the great mass of snow in the Descent Pass, but the sharp dividing line between the granite and the dark-coloured dolerite above it can be followed round all three shoulders and across to the tabular hill E, and thence along the east side of the South Arm for a distance of more than 10 miles, keeping almost exactly the same level all the way. This sheet-like mode of oceurrence of the granite appears to be a constant feature in this area and is seen orer the whole south side of the Upper Kukri Hills (Fig. 18).

\section{'THe KuKRI HiLs.}

The Kukiri Jills project as a wedge into the depression where the ice from the South Arn meets that flowing east from the inland plateau. From them granite has been actually obtained at three spots, namely, (1) the western extremity helow D, (2) near the middle of the south side below D, and (3) the castern end of the upper portion helow the peak $D_{4}$, (See Section III, Plate VII.)

The hill D, as seen from the soutl, shows allout 2000 feet of dark roek (dolerite) oceupying the whole of the elift's, which fall sheer to the level of the iee, here about 3000 feet above sea-level. In the middle of this great mass of dark rock are three large triangular masses of a light-colonred rock which are planly visilule eight miles away. At the western foot of D is a still larger mass of pale rock which must be 1000 feet thick at least. Viewed from the nortl and west, this rock, which proved to be a pink granite, eould be seen semding tongues into the columuar dolerite, and the junction of the two $(699$, 700 , see p. 128) was seen to be quite irregular; it is quite elear that the granite is here the later intrusion. The joint-planes of the granite dip to the north-east at an angle of nearly $30^{\circ}$; the granite (701), thongh grenerally pink in colour, has oreasional dark-grey masses (702-703) locally contained in it.

The astern ent of Solitary Rock $\left(D_{5 n}\right)$ shows four lands of rock with regular lorizontal junctions. Two of these bands are dark-brown and two are light-yellow in colour', and the altermation of the colours suggests that the rocks are like those seren on the north side of the North Fork, where yellow and black bands oceur in the same order and with similar thickness. 
When the Kukri Hills are observed from Knob Head Mountain, or from the smmmit of Descent Pass, they present an almost sheer wall facing south. This wall is broken at regular intervals by glaciers, which usually occupy hanging valleys. At the mouth of each valley there is a well-marked junction of dark-coloured and lightcoloured rock, and in places the eolours alternate regularly as heforc. The hill I) contains a straight yellow band near its summit which is formed by a dark rock. The yellow band continues towards the east, and gives to the hill $D_{1}$ a tabular outline. On the hill $D_{2}$ it is only represented by a small outlier. Below this yellow band on

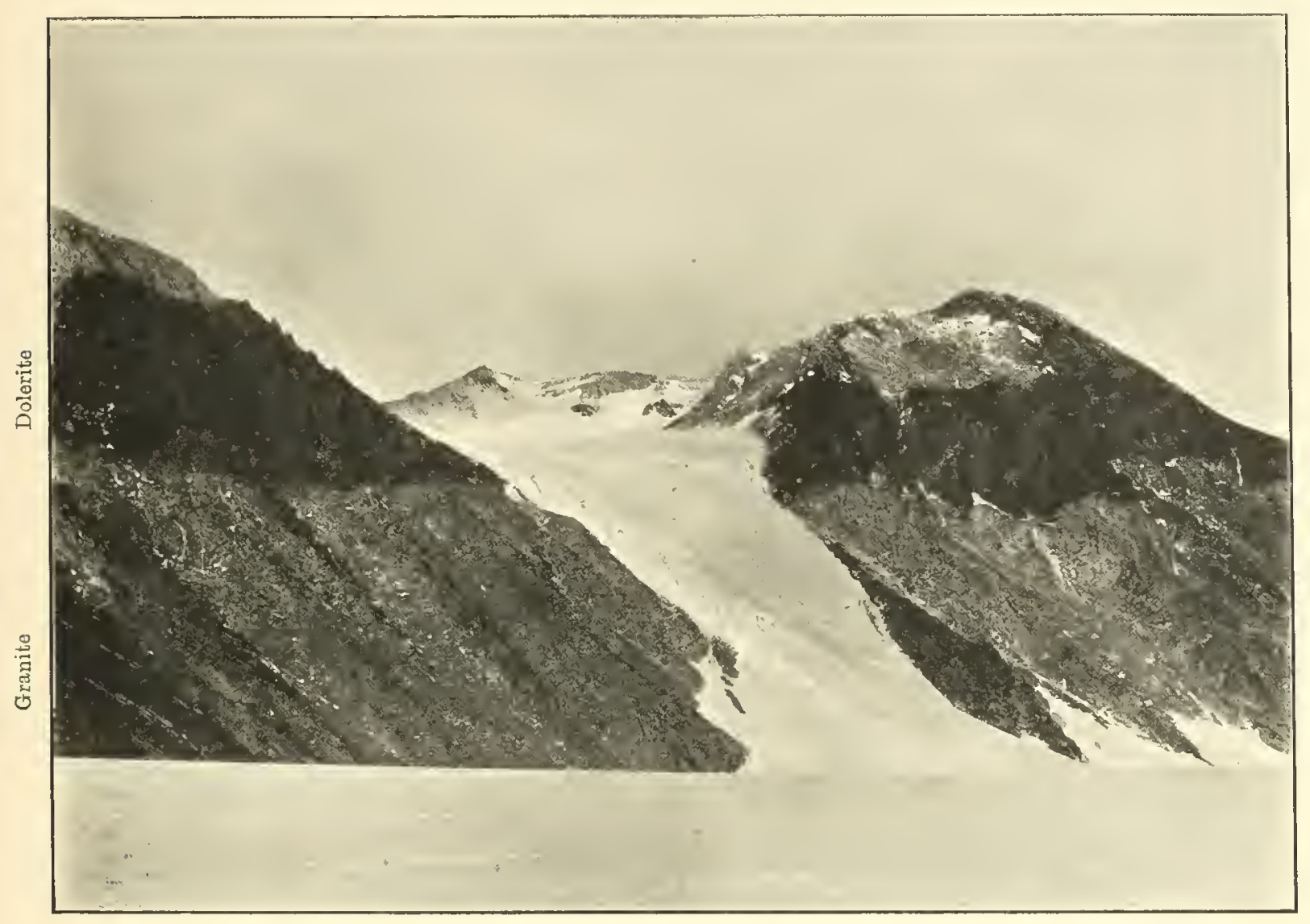

Fig. 18.-Tie Horizontal Upper Surface of the Granite on the south side of tife Kukri ilils.

the hill $D_{1}$ there is a horizontal black hand about 1000 feet thick, which appears to be part of the dolerite of $\mathrm{D}$, and this back band extends castwards beneath the yellow outlier of $\mathrm{D}_{2}$. Below the black band there is an attenuated wedge of yellow rock, which begins about the middle of the eliff $D_{1}$, and, rising slightly, reaches the top of the cliff-face a little to the east of $\mathrm{D}_{2}$. This yellow wedge shows prominent joint-planes which dip to the east, and appears to weather in quite a different way to the outliers on the summits of $D_{1}$ and $D_{2}$. It is possible that this is part of the intrusive grenite of the promontory D. Below this again is a second dark band, which was sulsequently proved to consist of dolerite ( 504$)$. This, too, is a part of the D mass, and maintaius 
a uniform thickness of abont 2000 feet. As it rises to the eastward it forms the highest third of the hill $D_{3}$ and eaps the hill $1_{1}$.

Below D, another light-eoloured rock, a grey biotite-granite (708), protrudes through the ice, and may be followed for a distance of over 10 miles along the side of the valley. The upper surfaee of the granite is very well marked and forms an almost horizontal straight line, but near the hill $D_{3}$ it beeomes somewhat undulating (Fig. 18). This granite forms the greater part of $\mathrm{D}_{4}$, and finally forms the summit of the hill $\mathrm{m}$. It is prohably at least 4000 feet thick. Below $\mathrm{D}_{2}$ the junction of the lower dolerite with the grey granite is 500 feet above the iee, as measured with an aneroid barometer, and about 3000 feet above sea-level, and it would seem that the surface of the granite slopes west at an angle of about $2^{\circ}$. This spot is five miles east of the pink granite at D, eight miles N.N.W. of the granite at Cathedral roeks, and ten miles N.W. of the granite at $\mathrm{G}_{3}$.

Grey augen-gneiss forms the base of $\mathrm{D}_{4}$, and was again eneountered at the foot of $m(727)$. At this last-mentioned spot, as stated in the foregoing ehapter, the augen-gueiss adjoins the metamorphie limestone, but a glacier completely covers their junction. From a distance it was seen that the junction must oeeur just where the higher and western part of the Kukri Hills cuds and the lower and more muiform eastern part hegins. The augen-rock must be more than 3000 feet helow the dolerite-granite junction and at least eight miles cast of the hill $\mathrm{D}_{2}$.

From a consideration of the above it would seem that the grey granite of these hills is older than the dolerite which rests upon its even upper surfice, hut that the pink granite of $\mathrm{D}$ is intrusive and later than the dolerite.

\section{In MoraINTS.}

Fifty miles inlaml, at a height of 4000 feet alove sea-level, smill and large boulders of both grey and pink granite (693) were found on the side of Beacon IIeight West. They were resting upon a surface of the Beacon Sandstone. The spot. where these fragments oceur is some distance up one of the 1)ry Valleys. As the lant south of the Dry Valleys rises to over 7000 feet in height, it is possille that anong these peaks granite oeeurs at a greater elevation than 4000 feet, and las been hrought down to its present place upon the sindstone by the ice which once oecupied the valleys.

Un the slope of Knob Head Mountain $\left(B_{3}\right)$ there were huge boulders of granite at a height of 4000 fect above the sea, hut no granite was fonnd in the npper part of the mountain itself. About one-thind of the material of the moraines in the South Arm romists of granite-blucks, and all valrieties appear to be there l'epresented. 


\section{Chapter VI.}

\section{TIIE BEACON SANDSTONE FORIMTION.}

The existenee of fossiliferous sedimentary rocks in South Victoria Land has becn eonsidered probable ever since H.M.S. 'Challenger' dredged up sandstones, limestones and shales* in a high southern latitude, but as it was thought that the eoastal belt of the land was eomposed entirely $\dagger$ of voleanic rocks, there was little to encourage the hope that fossiliferous strata would he met with in the course of the 'Discovery' Expedition.

In dredging off Coulman Island several small fragments of a white granular quartz-grit were brought up, and when just south of the conieal Nount Mellourne a tabular mountain, Mount Nansen, was seen, our hopes of finding sandstone were raised to a very high pitch. This mountain showed well-markel horizontal structure, and steep searp-slopes which vividly recalled Table Nountain at Cape Town in South Africa. Further south, in about latitude $75^{\circ} 57^{\prime}$, many tabular hills with black eaps could be seen fronting the sea, and the possibility of such tabular mountains being composed of plateau-basalt had to be considered. However, when the 'Discovery' anchored on the south extremity of Ross Island, the Western Mountains (the Royal Society Range of our present nomenclature) were seen to be made up of differently eoloured lrorizontal bands which run from end to end of the range. These rock-lielts are well brought out in some of the photographs, and at a distance of 50 miles the contrasts of colour were more obvious than in any of the photographs taken close at lank.

Lieut. A. B. Anmitage's pioneer-journey through these mountains proved that horizontal strueture and plateau-features are extremely constant. The specimens $(628,630,639-642)$ he brought back ineluded a sandstone which is somewhat like the Millstone Grit of the top of Ingleborough in Yorkshire, and suggested the probability of the existenee of fossiliferous sccliments in the distriet.

Lieut. Armitage reported that the sandstones attained a height of nearly 8000 feet and were accessible at a spot 60 miles inland on the very edge of the Inland-ice. The photographs taken by Lieut. R. W. SKELToN on this journey (Fig. 19) showed that the sandstonc has a marked effect on the scenery, and the name Beacon Sandstone Formation, which I propose to give to the deposit, is derived from the remarkable mountains $\mathrm{B}_{3}$ and $\mathrm{B}_{4}$ to which Lieut. Aruitage has given the name Beacon Heights.

Aceordingly Captain Scott arranged that I should go with him as far as the edge of the Inland-ice and do as much geological work as was possible on the return

* Murray, Geol. Mag., Dec. IV, 1898, vol. v, p. 270; Prior, Mineralogical Magazine, 1899, vol. xii, p. 81, note.

† Gregory, 'Nature,' 1901, vol. Ixiii, p. 609. 
journey. A second attempt had to be made, owing to the sledges breaking down on the first, and, even then, had weather confined the parties to their tents for a period of six and a half days; when the weather had moderated I had but one montl in which to examine the 600 square miles of new country.

From what we had seen on the way out, plateau-dolerite would be found overlying the Beacon Sandstone. The latter was not exposed at Depôt Nunatak, but in the moraine at the foot of the rock I found aloundant sandstone hocks, and the majority of these were locally blackened by carbonaceous matter $(743,744)$. None of these blocks contained fossils, other than the small lenticles of carbonaceous material which I thought suggestive of organic origin. These were our first evidenees of Antarctic life in the geological past, and as my eompanions, Krnvar (P. O.) and Welier (A. B.) spread out our sodden gear in the sun under the lee of

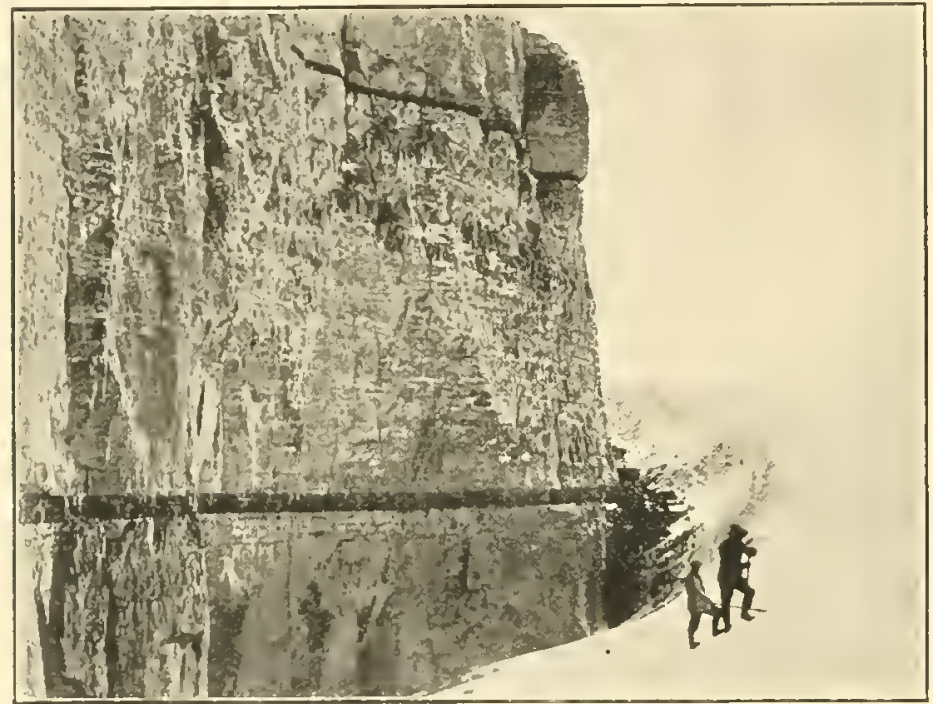

Fig. 12-DOLERITE-SILL IN THE BeAcoN SANDSTONE NeAr Finger Mountain. the nunatak, hopes indeed ran high, and all looked forward to the joy of further new discoveries.

Next day therefore found the camp near the foot of the hill $B_{1}$, where three hundred feet or so of the sandstone could be seen cropping out below the overlying dolerite. lmagine my delight when, arriving with bag and hammer at the rock-face, I found thin, black, irregular bands in a pure white sandstone. Though the bands were two hundred feet below the capping dolerite, their carbonaceous material was mueh charred; hence, after collecting a few specimens, we left this promising locality, perhaps prematurely, and moved diagonally down the ralley to the vast exposures of the Inland Forts. Here I had hoped to find better specimens, but neither here nor elsewhere did we meet with anything nearly so good as at our first locality near the dolerite-junction. The sandstone of these Inland Forts is quite 2000 feet thick, and, though we carefully sought for its base, no indications of that base or of the relations to the underlying rocks could be found.

The Beaeon Sundstone is also present at the foot of Knob Head Mountain, which is over 30 miles to the east of Depot Numatak and about 3000 feet lower. The localities at which the Beacon Sandstone was examined- will therefore lec considered in turn, in the order in which we came to them. 


\section{Below the Ilill $B_{1}$.}

From a position on the side of the hill $B_{1}$, we could see some miles away striking alternations of dark and light bands just peeping up from below the hrown rock of $a_{15}$. The dark bands are conspicuously paler than the overlying rock (dolerite) and are presumably carbonaceous sandstone. If we take this into consideration and the fact that arbonaceous sandstone is found in the Depôt Nunatak moraine, and bands of it ocur below $\mathrm{B}_{1}$, it would seem that only the upper portions of the Beacon Sandstone are fossiliferous.

The Beacon Sandstone at $B_{1}$ is locally disrupted by the dolerite, but the horizonta! bedding is not materially disturbed, except at one place where huge masses of the sandstone have been bodily upraised. One of these dislocated masses is 100 feet thick and a quarter of a mile long. It contains many small black iron-stained nodules (66.3), which are set in a matrix of very coarse quartz-grains. Of the 300 feet exposed near the camp, the major part is a pure, even-grained, coarse sandstone.

False bedding or current-ledding is displayed, and locally there are discontinuous bands of quartz-pebbles $(673,674)$. The pelble-bands appear and disappear quite suddenly in the ordinary sandstone, and they are never more than four inches thick; the pebbles themselves vary from the size of a sparrow's egg to that of a hen's egg, and quite 99 per cent. consist of rein-quartz or quartzite (672). Sometimes the pebbles are very sparsely seattered, and a berl 12 feet thick may contain only a single pebble. The quartzite (quartz-schist) pebble (675) was found under such circumstances and measures $8 \times 5 \times 4$ inclies. The sandstone-blocks of Depôt Nunatak display abundant lenticular pieces of yellow mudstone up to two inches in length, but these lenticles were not observer elsewhere.

The carbonaceous matter $(743-76 \cdot 2)$ only occurs in the lowest hundred of the 300 feet exposed; the carbonaceous bands, like the pebble-bands, are there discontinuons, and often follow the intricacies of the current-bedding. The black handis commonly range from an eighth to a quarter of an inch in thickness; some of them were found to extend horizontally for quite 100 yards, others disappear completely within a very few feet.

Near this spot the sandstone is partially calcareous, and a blue limestone-band formed a conspicuous shelf projecting from the cliff-face. Just below this was a well-marked hand of pebhles set in incoherent sand, or in sand only slightly cemented by carbonaceous matter. The following sequence, in order of superposition, will give some idea of the nature of the Beacon Sandstone at this spot.

Top. (i) 200 fect-almost pure sandstone with occasional pebbles (605)

(6) 2 feet-band containing carbonaceons substanee (745-762)

(5) 12 feet-sandstone with brown bands

(4) 12 feet-hard white sandstone with a three-ineh strip of fibrous mineral (wollastonite) (676)

(3) 12 feet-black shale and shaly sandstone (7.51)

(2) 6 inches-limestone-band $(6 ; 1)$

Bottom. (1) 6 feet-black shale (75t) 
The carbonaeeous band (6) had been slickensided and haked to such an extent that it has proved impossible to determine the fossils which it contains (see report by Mr. E. A. Newell Arber, on p. 48).

\section{The Inland Forts (Fig. 20).}

Five miles west of the Inland Forts, at the spot marked $\gamma_{2}$ on the map, the cliff forming the north sile of the glacier is composed of two rocks, a yellow one below and a dark one above. The junction as usual is regular and almost horizontal. On examination the yellow rock proved to be sandstone. The only accessible part was the base of the cliff where the rock is a sandstone barren of fossils. It is subdivisible into a series of alternate yellow and white beds, and

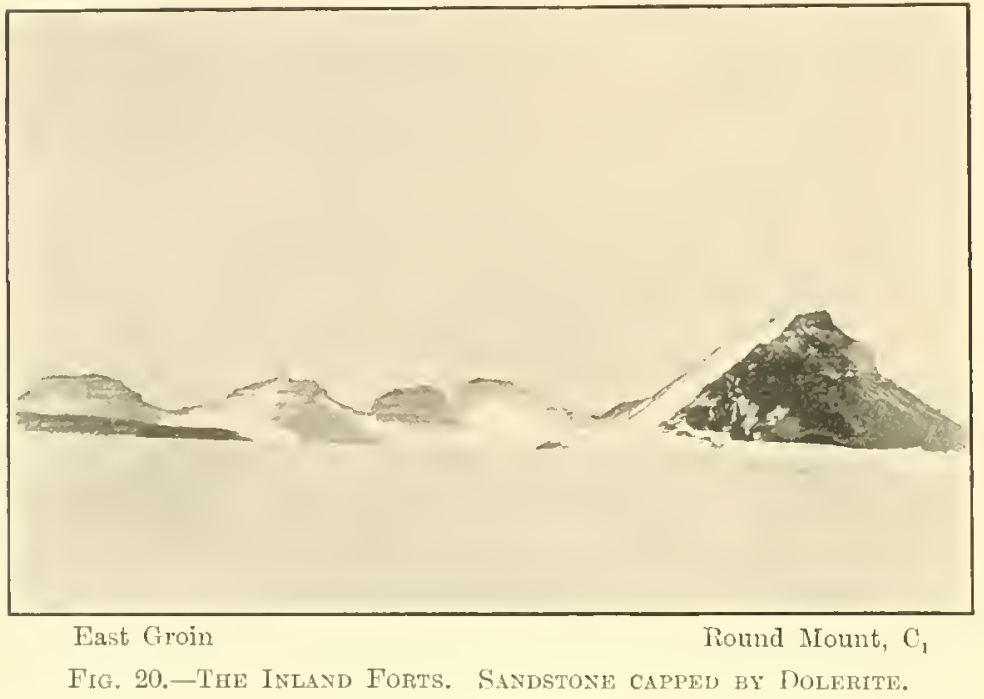

a few pelble-patches were noted. The following section from the level of the ice upwards, shows the order of snecession :-

Top. (1) 100 feet-brown coln $\mathrm{mnar}$ rock (dolerite)

(:3) 100 feet-yellow sandstone

(2) 100 feet- miformly light - coloured sandstone

Botlom. (1) 100 feet - a yellow and mnch banded sandistone.

At the Inland Forts, where the hills are at about the same level as those below $\gamma_{2}, 2000$ feet of the Beacon Sandstone are exposed, and of this nearly 1500 feet have been examined. The Forts are four conspicuous hills mainly composed of sandstone, lint they are capped by dolerite (Fig. 20). They are separated by well-marked cols through which the ice once forced its way northwarts into the adjoining drainage-system. The exposure is well illustrated by the photographs of this side of the valley. The sandstone is part of a great deposit which is buried westwatrds beneath the Inland-ice and determines the distinctive features of the mountains on each side of the main valley of the Ferrar Glacier.

Extending southwarts from $C_{6}$ and $C_{8}$ are two rilges of similar sandstone. These ridges have rounded outlines and resemble groins built against a sea-wall to break the fore of the waves. Though now above the level of the ice, they formerly acter like groins and thus collected rock-material on their restward side. 'These ridges, which I have termed the West and the East 
Groin respectively, are low and attenuated spurs of the horizontally bedded sandstone, whieh is here eut into cirques. The groins afford the most easily accessible exposures of sandstone in the whole region. The slope was selitom too steep to be climbed, and, as the horizontal structure is well etched out by denudation, any particular bed may be traced along the whole length of the ridge. Here, too, the roek was a white or yellowish sandstone with not so much as a sign of a shale or a limestone-band. So far as could be ascertained, only one of its horizons contained organic remains, and these of a most doulitful nature. These were found on West Groin, where the surface of a sandstone-bed was covered by what appeared to he cylindrical casts of some organism (763-767). Possilly these cylinders may be entirely a result of weathering, but, as they are all of much the same diameter and cross and intercross in all directions, I thought at the time that they are probally more than this, and I still think that they may he of organic origin. There is no sign of actual structure in the boundaries of the cylinders, but there is usually a slight depression parallel to, and close along, their sides. The length of the cylinders raries from six inches to three fect, and the diameter is usually about half an inch; they project nearly half an ineh above the smootl surface of the surrounding sandstone.

At another spot on West Groin, 800 feet above the level of the iee, there oceurred au impression $(763,764)$ on the surface of the sandstone. This appeared as a shallow hollow, somewhat like the imprint of a flat crooked stick with a blunt rounded end (Fig. 21). The impression was an eighth of an inch deep, two inches wide, and one and a half feet long. Along the central line there are two markings parallel to the outer boundary and about a quarter of an

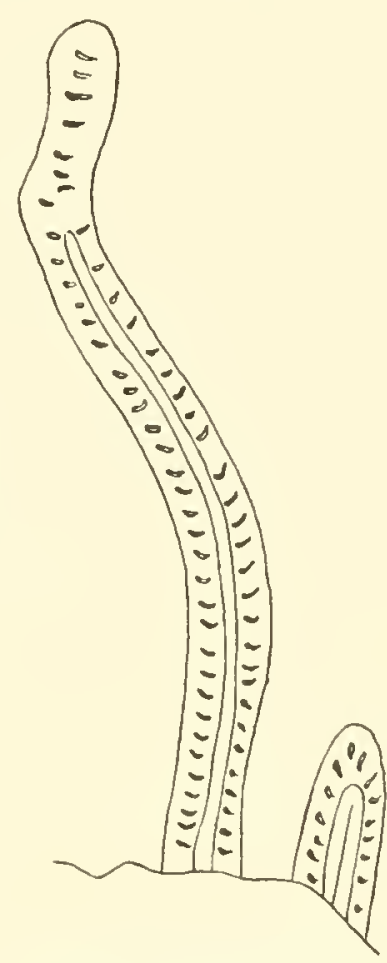

Fig. 21.-IMpRessiox IN SAND: StONe AT West Groix. COPY OF SKETCH MADE IN THL FIELD. inch apart. These run nearly the whole length of the impression, and on either side of them are rows of rather deeper pits about a quarter of an inch apart, which alternate on the two sides of the eentral lines (see note by Mr. E. A. Newell Arber, on p. 48).

Sundry other, but smaller, rod-like markings (765-769) oecur on other specinens, and with the same alternate pits, and I am inclined to think that these impressions are, at least remotely, derived from bodies with organic strueture. One of the smaller impressions, which are 6 inches to 1 foot loug and about half an inch across, still retains fragmentary remains of dark carbonaceous matter. The following table of the succession, from the bottom of West Groin to the top of its corresponding hill, shows how uniform is the Beacon Sandstone Formation. 


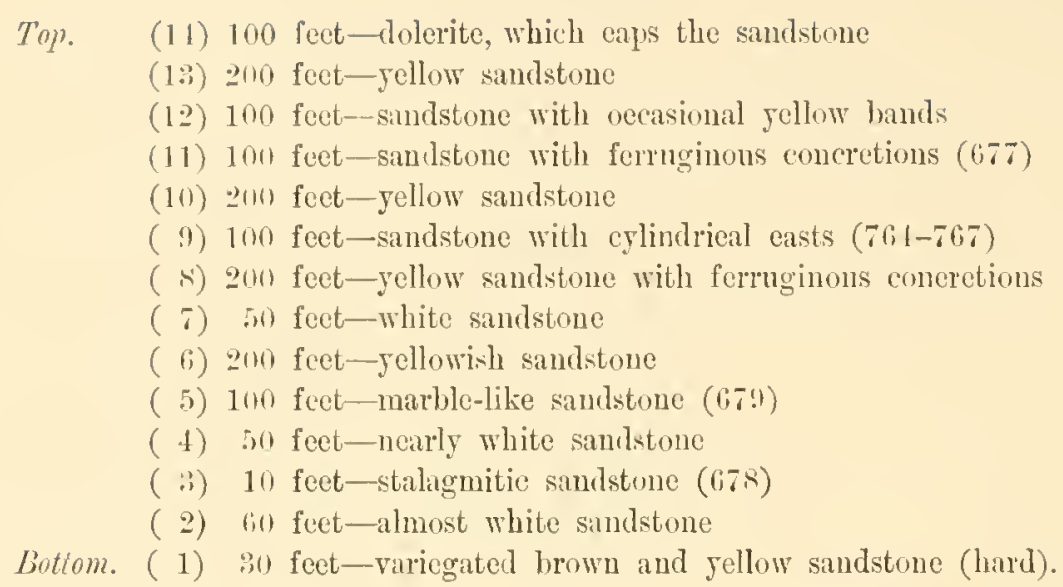

The variegated brown sandstone (1) at the base appeared to be altered to a slight extent; it is harder than most of the higher beds, and the ferruginous concretions in it are sometimes two feet aeross. They are flattened horizontally, and are sometimes joined together.

The stalagmitie sandstone (3) is so called beeause stalagmites stand out between suceessive lieds on the rock-face, and it would appear that the roek had heen locally hardened by infiltration. It is made up of alternate hard and soft layers which are each about a foot thick.

The marble-like sandstone (5) (679) was harder than that ahove and below, and loeally its surface has a superficial glaze. The ferruginous concretions (11) (677) in the upper loand often weather out as balls up to a foot in diameter; sometimes, however, the eoneretions have disintegrated faster than the roeks in which they were imbedded and have left spherieal hollows.

\section{Fincer Mountain (B) (Fig. 22).}

Before we entered the district of the Dry Valleys, the Beaeon Sandstone was examined near the foot of Finger Mountain; though 10 miles sontl of the preceding area, it retains the same charaeters and appears to be harren of fossils throughout. Near the eontaets with the dolerite, variegated bands (635) have been produced. At this spot the sandstone, like that at $B_{1}$, has been dislocated; but again its general horizontality has not been disturbed, notwithstanling that intrusive sheets of dolerite, up to 500 feet thiek, have foreed their way along joints and bedling-planes.

Finger Mountain (B) contains a wedge of sandstone which separates two sheets of dulerite (1ig. 22). One of these shects caps the hill; the other separates the wedge from the majur portion of the sandstone which only just appears above the ice. The whole sequenee oceupies a cliff of ahout 500 feet high; the werlge of sandstone is ahout 100 fect thick at its eastward extremity, whence it thins westwards and disappears in a distance of about two miles. One bed of sandstone after another is ent out by the dolerite as it transgresses them upwards to join the nuss which eaps the liills to 
the south of Finger Mountain. Immediately to the south of Finger Mrountain the wedge is considerably thinmer. It is exposed in the valley, which, eutting lack, produes the sharp spur marked $b_{1}, b_{3}$.

Again, on the north sile of the glaeier in Rouml Mountain $\left(C_{1}\right)$ is a wedge of yellow rock, which is prohahly a similar sandstone, and is also caught up loy the dolerite in exactly the same way. This mountain, however, differs from finger Mountain in having a small sandstone-outlier which eaps and protects the dolerite at the summit.

Aloug the right lank of the Ferrar Glacier from $B_{1}$ to $B$ the sandstome may be seen above the level of the ice, but local disturhanes prevent the upper surface from appearing as a continuous line along this side.

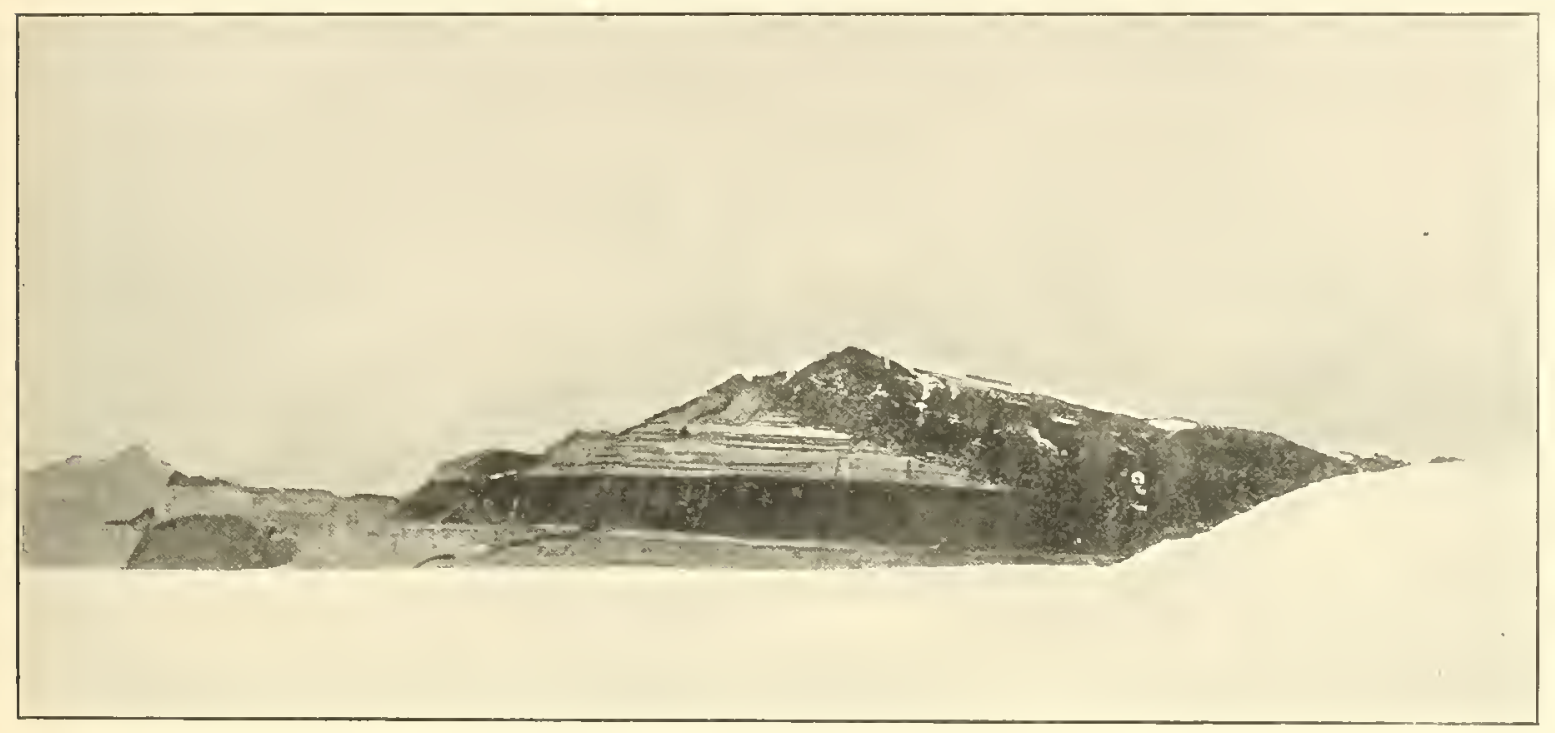

Fig. 22.-Finger Mountain. Wedge of Sandstone ix the Dolerite.

The Dry Thaters (Plate T).

These two valleys lie on the south side of the Ferrar Glacier and on the west side of the Beacon Ileights $\left(B_{4}, B_{3}\right)$. Both have vertieal sides 500 feet high, which suddenly give place above to less steep slopes as the surrounding mountains are approached. Both are tributaries of the main valley. The smaller lies immediately south of Finger Mountain, and, narrowing the while, trends due west for a distance of two miles; at this point the valley suddenly turns southwarls, the ice which oeeupies it suddenly ends, and displays a bare, flat, stony hed. The confining walls continually approach each other, and one mile above the ice-eliff they suddenly come together in a veritable cul-ele-sac.

The larger valley is about four miles long and also ends in a cliff. Its sides are steep and parullel, and maintain the same height all the way roum. The 
valley-bed here also is flat and free from ice; it is strewn with boulders of all sizes, and is therefore exceedingly rough. The breadth is less than two miles, but near the mouth, where it is joined by the smaller valley, it widens, and together they open out into the main depression of the Ferrar Glacier.

The Beaeon Sandstone on the north side of the smaller valley is most aceessille at a spot west of $b_{2}$, where the usual sandstone is eapped loy dolerite. About 300 feet are exposed, and the beils can be traced lorizontally all round the left side until cut off by the dolerite of the hill $x$. The main mass of $x$ is dolerite, but a small exposure of sandstone is visible at its westem foot. In the middle of the mass there are two other narrow strips of sandstone, each alout 20 feet thick and half a mile long, which seem to have been caught up by the intrusion. At the west foot of this hill the Beacon Sandstone shows a new feature, for on the nnder side of a large block there was a six-inch bed composed of angular quartzfragments (681). These pieces of quartz are fairly regular, almost eulic, and abont an inch long. They are set in a matrix of the usual sandstone, and it is worthy of note that no romuded pebbles were here observer.

There are four very prominent luttresses south of $x$, which form the sides of the larger valley, and in each of the buttresses two bands of yellow rock and two of brown rock were seen alternating regularly. These alternations possilly represent parts of once continuous intrusions of dolerite which follow the same hedding-planes across the whole area. A similar arrangement also holds in the buttresses of the eastern valley wall.

The Beacon Heights $\left(\mathrm{B}_{4}, \mathrm{~B}_{3}\right)$ (Plate $\mathrm{V}$, and Section I, Plate VII).

On the western side of Beacon Height West $\left(B_{4}\right)$ there is a small outerop of the Beacon Sindstone. This, as before, has lrorizontal bedding-planes. The bulk of the rock is coarse, even-grained in texture, and almost white in colour. The greater part of the mountain appears to consist of sandstone, for the lower 2000 feet shows a yellow rock, with horizontal joints or bedding-planes, where the even covering of dark talns-products is wanting. The summit is a small cap of brown rock, which is separated from a larger mass of the same brown rock loy a band of yellow about 500 feet thick, also bedded horizontally. The larger mass of brown rock is continued in the summit of $B_{3}$, and even extends to the summit of Knob Head Monntain further to the east.

The sandistone crops out as a small cliff on the side of this momntain $\left(B_{4}\right)$; there the cylindrical rugosities (see p. 43) are again developed and appeared to be quite similar to those observed on West Grom. This outerop was traced for a distance of a quarten of a mile along the hillside, and the cliff is on an average 50 feet high. 


\section{The Terra Cotta Mountains (Fig. 23).}

The Terra Cotta Mountains $\left(\mathrm{B}_{6}, \mathrm{~B}_{7}, \mathrm{~B}_{8}\right)$ appear to be composed mainly of sandstone. They are abundantly riddled by dykes of dolerite which appear to have had considerable effect on the sandstone. The sandstone has a pale-pink tinge, and in the distance the hills have a dull-red colour, which eontrasts strikingly with the dazzling snow and the yellow sandstone elsewhere. Some of the specimens from the moraine show that the sandstone has been altered to quartzite (697). The dykes will be mentioned in the next chapter when the dolerite-rocks are considered.

\section{Knom Head Mountain $\left(B_{9}\right)$ (Plate V).}

The last spot where the Sandstone Formation was examined is on the east side of Knob Head, 30 miles from the South-west Arm or the hill $B_{1}$, and about 30 miles from the sea. Here a small outerop, similar to that on the west of Beacon Height, is found at an elevation of about 3500 fect. At a distance the whole lower portion of Knol, Head Mountain appears to consist of the sandstone. The mountain, like the Beacon Ileights, has a small cap of dark-coloured rock (dolerite), which is separated from a larger sheet below by a narrow

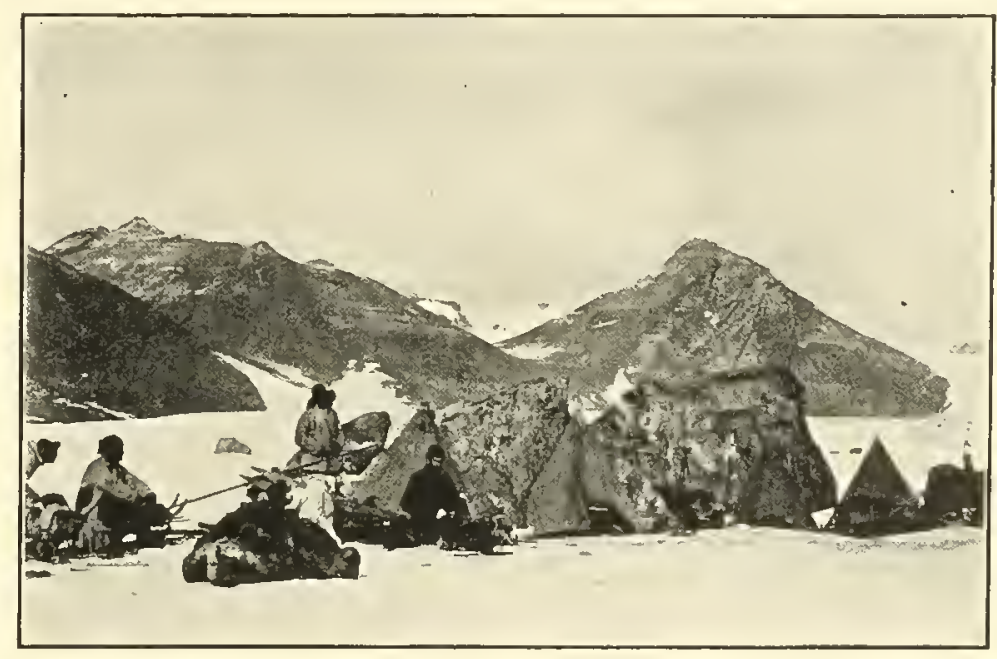

Fig. 23.-Terira Cotta Mountains, showing Drkes of Dolerite. and horizontal yellow band. This similarity in the summits of the three mountains makes it probable that all are parts of the same two sheets of dolerite.

The sandstone-outerop on Knob Head is less than a quarter of a mile long and about 100 feet high. Here again one bed was observed to have, all over its surface, cylindrical prominences like those described on page 43. At this spot, also, some beds contain alternate dark-coloured and light-coloured laminations, but nowhere did the rock show bands at all like the black bands found near the foot of $B_{1}$, nor was there found any structure in these dark lamine which would suggest organic life. 
REPORT ON THE PLANT-REMAINS FRON THE BEACON SANDSTONE.

\author{
By E. A. Nemeld Arber, M.A., F.L.S., F.G.S., University Demonstrator \\ in Palieobotany, Cimblidge.
}

THE remains collected by the 'Diseovery' Antarctic Lxpedition, and regarded as probably of the nature of fossil plants, are unfortmately of little value botanically.

The material was derived from two localities, viz., the hill $B_{1}$ in the South-west Arm of the Ferril Giaeier, and the Inland Forts. The speeimens of Beacon Sandstone, containing much carbonaceous material, from the hill $B_{1}$ were eollected by Mr. Ferrar on the 12th and 13th of November, 1903, at a height of 50 feet alove the level of the ice (see p. 41). Several of these show fair-sized, carbonaceons impressions or markings, which, in all probability, are of vegetable origin. One example somewhat resembles in appearance a piece of petrified wood, but a mieroscopie scetion made from this material has failed to show any trace of organic structure.

The sperimens from the Inland Forts are pieces of a pale yellow sandstone, obtained ly Mr. Ferrar on November 16, 1903, at a spot some 800 feet up the West Groin (see p. 43). Some of these show one or more series of irregular puckerings, consisting of slight pits or depressions, sometimes lined hy a small amount of carhonaceous material. It appears, however, to be impossible to form any opinion as to whether these features are due to vegetable agency or otherwise.

The imperfect evidence presented by these specimens will neither permit of any opinion as to the lotanical nature or attinities of the fossils themselves, nor of the geological age of the beds in which they oceur. Their discovery may, however, he regarded as affording indieations that, at some period or other in geological time, vegetation flomished so far south as latitude $77_{2}^{10}$. Such a conclusion is of great geological interest, and is in hammon with the faet, now ascertained heyond doubt hy the dismvery* of abundant evidence of varied regetations belonging to several different geological epochs, that the elimate of the Antareti", as of the Aretic regions, has heen much more genial at more than one period in the past thin at the present day.

* Nithorst. A. G., Sur la tlore fossile des regions antaretiques, Cumpt. Rend. Acat. Sci.. 1904, exxxviii, p. 1447. 


\section{Chapter Vil.}

\section{THE DOLERITES.}

THE doleritic type of rock has been found in practically the same localities as the Beacon Sandstone, and it will, therefore, be convenient to consider the localities in the same order as before. The dolerite of Depot Numatak is the highest point from which rock of any lind has been collected in South Victoria Land. Dolerites occur here at an elevation of 7000 feet, and, at the foot of Knob Head Mountain, about 30 miles nearer the coast, they have also been seen only 3500 feet above sea-level. There is no evidence of the presence of surface-outpourings, and as no vesicular or scoriaccous rocks were observed, even in the moraines, it would appear that these rocks are wholly intrusive.

\section{Depôt Nunatak (A.)}

(Figs. $24 \& 25$ ).

Lieutenant A. B. Armitage on the first journey through the Royal Society Range obtained weathered dolerite - fragments $(632,633)$ at Depôt

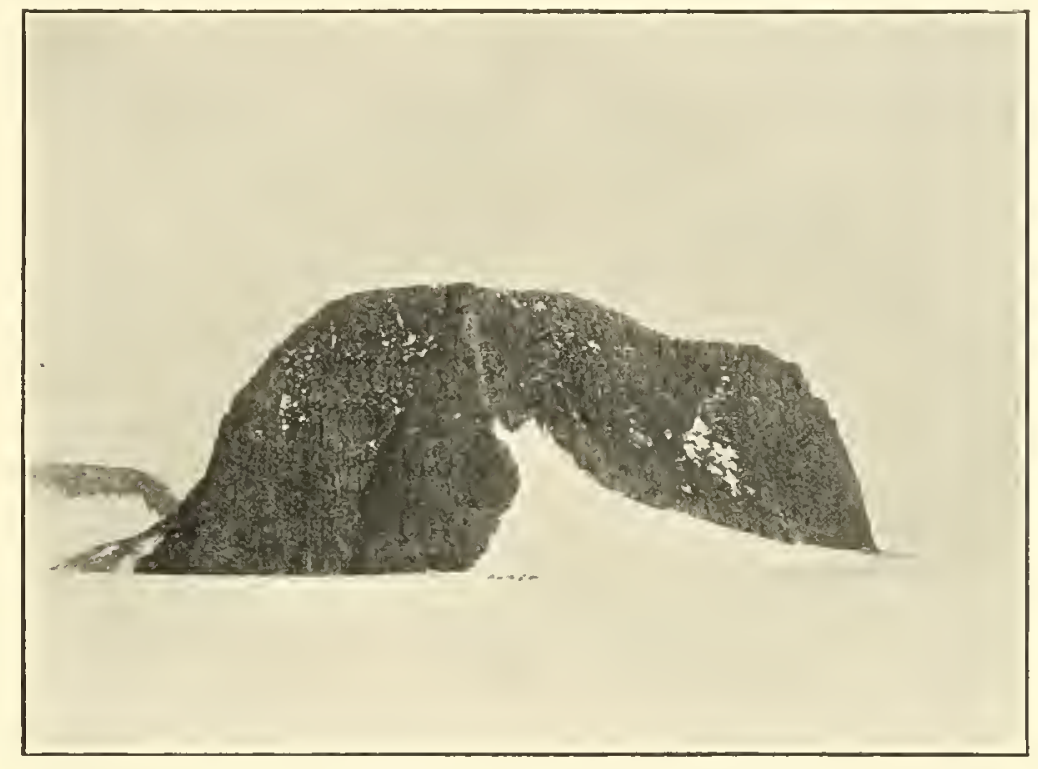

Fig. 24.-Depôt Nunatak, from the EAST.

Nunatak, and at the same time Engineer-Lieutenant R. W. SketTon plotographed the parent rock which rises as a mass of great columns through the suow. The rock $(662)^{\circ}$ is an ontlier, and protrudes through the snow at an elevation of alwut 6000 feet. The numatak rises to a height of nearly 500 feet above the snow and is exceedingly columnar throughout. Some of the columns are 12 feet in diameter and, though broken, give the impression that they extend the whole height of the cliff. Depot Nunatak is 60 miles from the coast and is entirely cut off from the dolerite capping the sandstone eight miles to the east.

The Hill $B_{1}$.

There the dolerite caps the sandstone and produces a eliff which rises vertically for more than 500 feet. 'This cliff forms the east side of the South-west Arm for' a length of ten miles. As before, the columns which go to make up the sheet are voL. I. 
about 12 feet in diameter, and weather to a bright-chocolate colour. At its junction (668) with the sandstone it becomes finer in texture, and it has obriously altered the sandstone for a distance of two feet, at least, from the contact. At one spot a mass of sandstone has been caught up in the sheet, and, near by, a pipe of dolerite 50 yards in diameter cuts vertically across the hedding-planes of the sandstone. The sheet extends along the side of the ralley towamls Finger Monntain and is interrupted by ocrasional small faults, the throw of which is always less than 100 feet.

\section{The Inland Forts (Fig. 20).}

On the north side of the Fermar Glacier the hills are very miform in height and are eapped ly a dark rock for a listance of 20 miles. At the point $\gamma_{1}$ a pipe or dyke of the dolerite cuts through the sand stone and joins the mass above, and it $\gamma_{3}$ there are two sheets of lolerite separated by sandstone. Further east again, at Ci. the cap of dolerite has been remover by denullition, and the lower sheet, which is reduced to under 100 feet in thirkness, caps these isolated lills. Near the Inlanr Fints three dylies of the dolerite were examined,

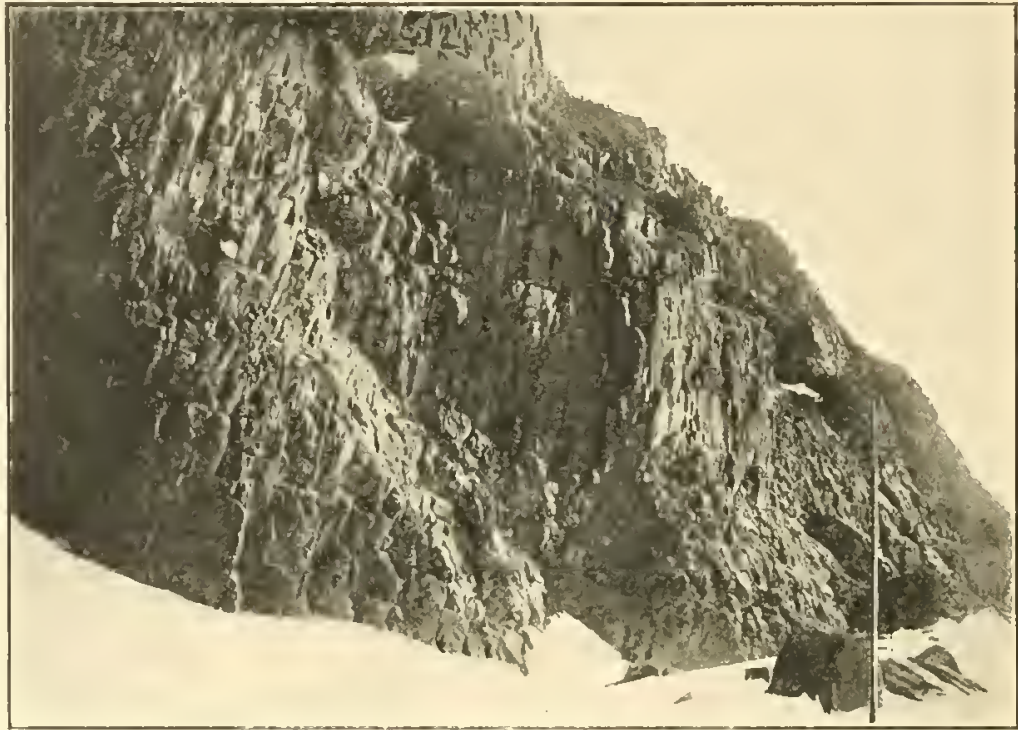

Fig, 25. Collmar Doleritr. of Depitit Nevatak. and a series of specimens (682-688) of dolerite and sandstone was collected along a line transwerse to one of these dykes. These dykes are almut 12 feet across and rise vertically throngh the sandstone to join the dolerite-sheets above. Where the dolerite meets the simdstone wenthering has been acceleraterl, and the dylies lie in chimmeys which are sometimes 20 feet deep. One of these pipes is on the sonth end of Wrest Gruin, the other on the north end of bast Groin and close to Whest Fort (cig).

\section{Finger Mountuin (B) (Fig. :2:2).}

'This nommtain is 7084 feet high, and is composed of alternate layers of sandstone and dolerite. The lowest rock visible at the base is Bcacon 
Sandstone, of which not more than 100 feet appears. Above this there is at sheet of columnar dolerite 200 feet thick, whieh on the west side of the hill unites with another sheet of dolerite. These two sheets are separated ly the wedge of sanilstone alleady referred to in Chapter VI. The bedding-planes of this wedge are horizontal, and are made conspicuons by the intrusion of numerous thin sills of clolerite along them. The wedge tapers to the west, and at this enrl the columms of dolerite do not appear contimuous throughout the clift, lut lreak and liend over to the west at a line which follows the inclination of the uppere surface of the now absent wedge. Finger Nountain narrows eastward to a sharp spur $\left(b_{1}-b_{2}\right)$. The upper sheet of dolerite ents at a scarp at the summit of $B$, while the lower continues some distanee and is ent off by a struture-line, parallel to the line of transgression followed by the sill above the sandstone-wedge. This spur is eapped by an ontlier of the dolerite, which is separated loy sandstone from a lower sill of transgressive lolerite 200 feet thick.

Specimens were colleeted both from the last sheet (692) and from a dyke (691) entting across the bedding-planes between this and the one above. Dykes and sills are numerous at this rather disturbed locality. A sill of dolerite 30 feet thick extends for a hundred yards along a ledding-plane, then terminates suddenly with a rertical end. Another sill 10 feet thiek runs along a berding-plane for 50 yards, brealis steeply downwards for 50 feet, and then, forcing its way along a bedding-plane for 100 yards, finally thins out and disappears. A third sill, 2 feet thiek, extends 50 yarls along a horizontal heding-plane, lut gradually deereases in thielness and ends as a wedge.

The specimens (695, 696; see p. 138) were eollected from the base of $x$, from a sheet of dolerite below 200 feet of sandistone. Here also the dolerite occurs in sheets which alternate with the layer's of sandstone, and dylies and thin sills are numerous.

\section{Kyob Head Movxtaly $\left(B_{9}\right)$ (Fig. "6).}

At a height of 3000 feet above the sea, and 30 miles inland, close under the foot of Knob Head Mountain, which is over 8000 feet in altitule, there is a cliti, 100 yards in length and 200 feet high, romposed of eolumnar dolerite. Above the clift the hillsile slopes up more gently, and is eovered with drift-hlocks of granite and dolerite ; the corering is hroken only hy this exposure of rock near its base. The outcrop shows columns 12 feet in liameter, and from 20 to 200 feet in height. There are vecasional horizontal cross-joints, but cup-ant-ball structure is not leveloped. The Beacon Sandstone appeared to rest upon this dolerite-mass (661); it forms the main mass of the mountain, hut the junction of the two could not he found. The hill $\mathrm{B}_{6}$, three or four miles to the west, consists mainly of sanclstone, lut is rildled by dykes whieh form a network on its surface. On its west side there is 
a pipe of dolerite about 100 feet in diameter, which rises vertically through the sandstone, lut cammot lie traved to a junetion witl any of the overlying sheets of dolerite.

\section{The Kukri Mrhls (Fig. 27).}

The bluft' $D$ forms the western extremity of the Kukri Hills and, as alrealy stated, eonsists mainly of dolerite. If referenee be made to the seetion along the Kukri Hills (Section III, l'late VII) it will be seen that two parallel sheets of dolerite, each

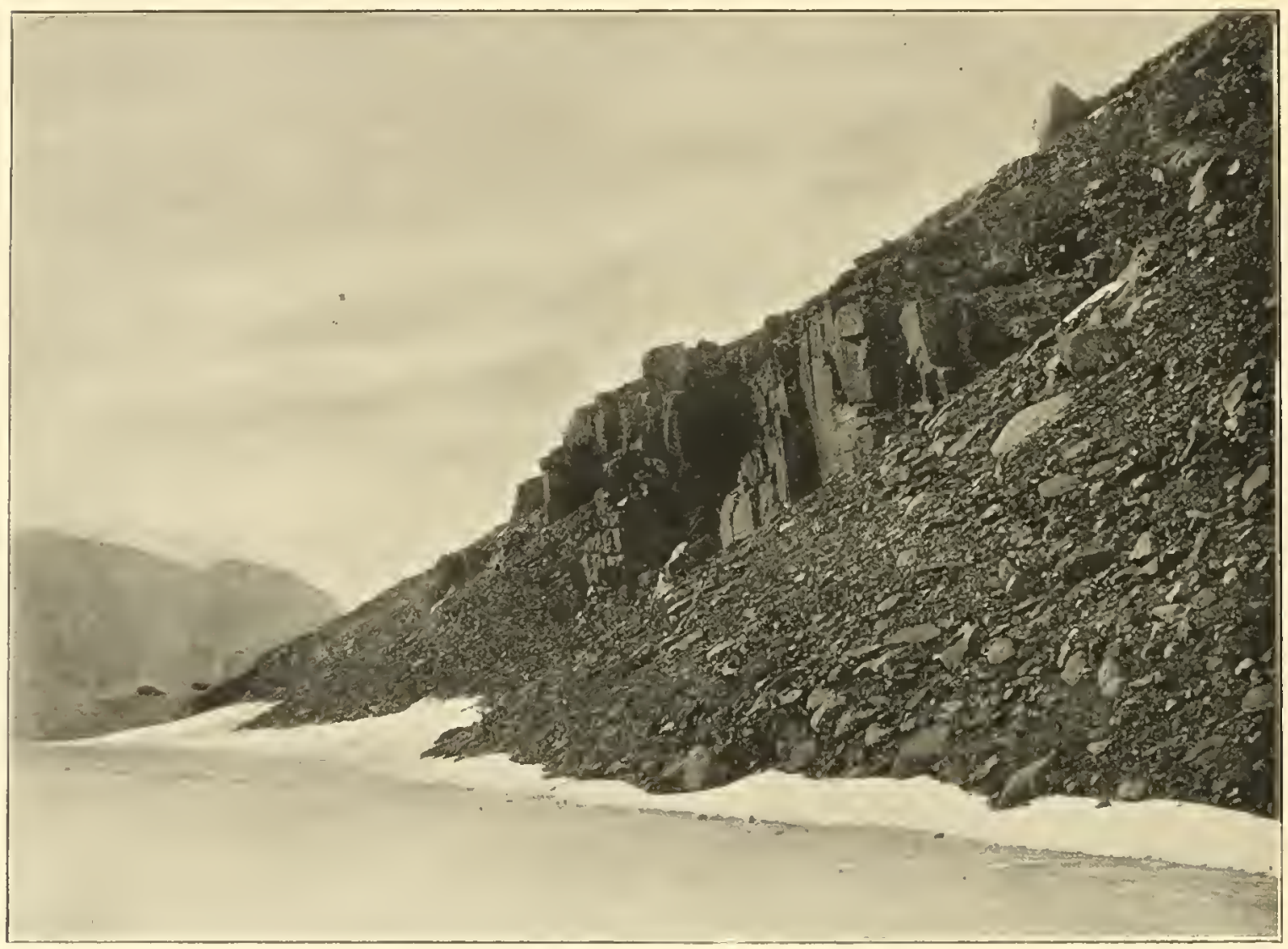

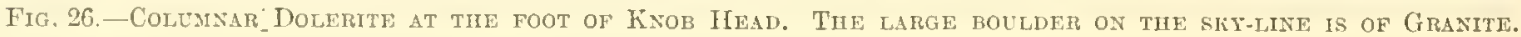

about 2000 feet thirk, run together at D. These sheets dip to the westward, and a specimen (704) obtained shows that the dolerite becomes finer in texture at its junction with the granite. The speeimen was got from just above the lower junction and below $D_{2}$. The junction here is most striking and extends in an absolutely straight line for a clistance of 10 miles along the side of the East Fork.

from the regular alternations of yellow and dark-eoloured rock, I was at first inclined to suppose that there are two sandstone-deposits, but further work proved that the intrisive sheets cannot be continuous over the whole area. It would, however, be interesting to know what struetural weaknesses have indueed the 
dolerites to maintain uniform horizons for so great a distance, and to remain always separated by the same thickness of sandstone. The sandstone between the sills is always about 500 feet thick.

\section{The Former Extexsion.}

On consideration of the facts stated above, it will be seen that wherever a dark rock was encountered it proved to be dolerite; further, all the abundant dark fragments in the moraines belonged to that kind of rock. Dolerite has been shown to cap the highest sandstone seen, and to be intrusive into it on each side of the upper Ferrar Glacier. Some mountains are entirely composed of dolerite, and others, such as the Beacon Heights or Knob Head Mountain, have mere caps of that rock, which may be remains of a once continuous sheet. At the Cathedral Rocks dolerite must rest upon granite, and apparently at one time have been continuous with the sheet which eaps the granite in the Kuliri Hills. Further, the Royal Society Range, which is a faulted crust-block* and is higher than any of the surrounding country, has strongly developed plateau-features (Fig. 9, p. 23); the rock which forms the highest peaks is dark and therefore pro-

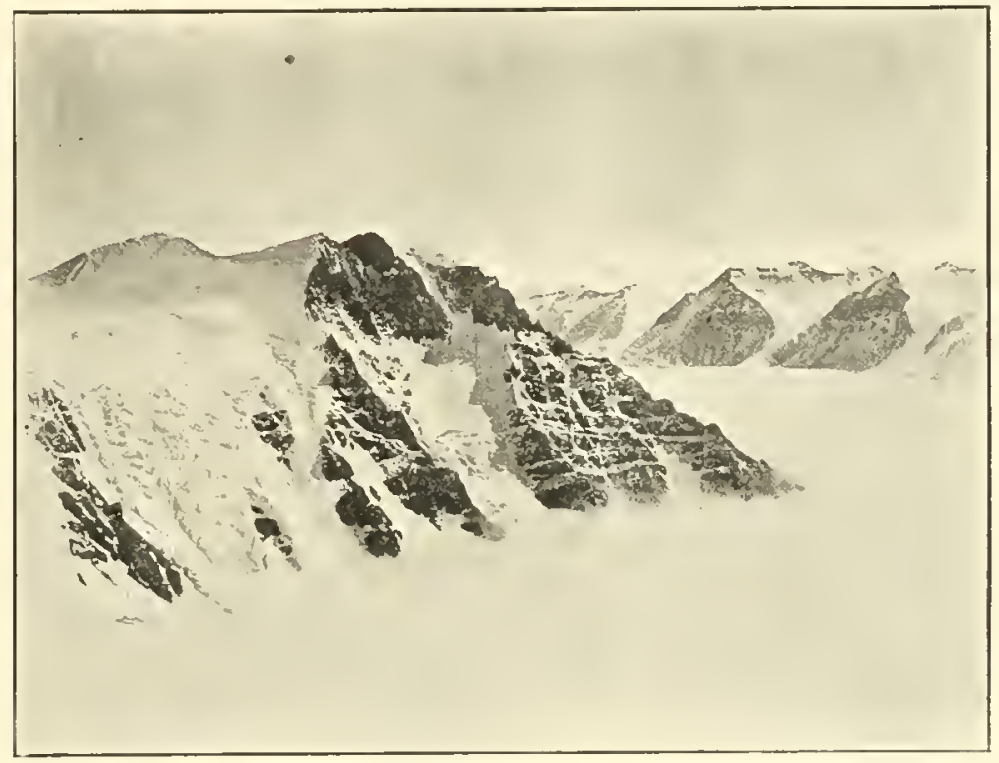

Cathedral Rocks

Kutri Hills

FIG. 27. THE DART BAND IN THE KUKRI HILLS ON THE RIGHT SHOWS

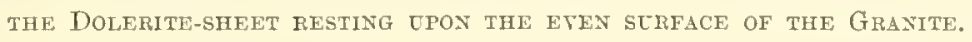

bably dolerite. If this be so, we may be sure that both dolerite and the Beacon Sandstone Formation extend quite 50 miles in an east-and-west direction.

Next, dolerite caps the Bearon Sandstone at the Inland Forts, and the hills for at least 10 miles north are capped by rock which cannot be other than dolerite. The contrast in colour between cap and sandstone is always so strong that this inference could be made even without regard to the evidence of abrupt changes in the hill-outlines at the junctions. For similar reasons there can be no doubt that the dolerite still caps the sandstone-hills, which extend 10 miles to the south of the main Ferrar Glacier (Fig. 28). These farts render it extremely probable that the

\footnotetext{
* Gregory, 'The Great Rift Valley' 1896, p. 220.
} 


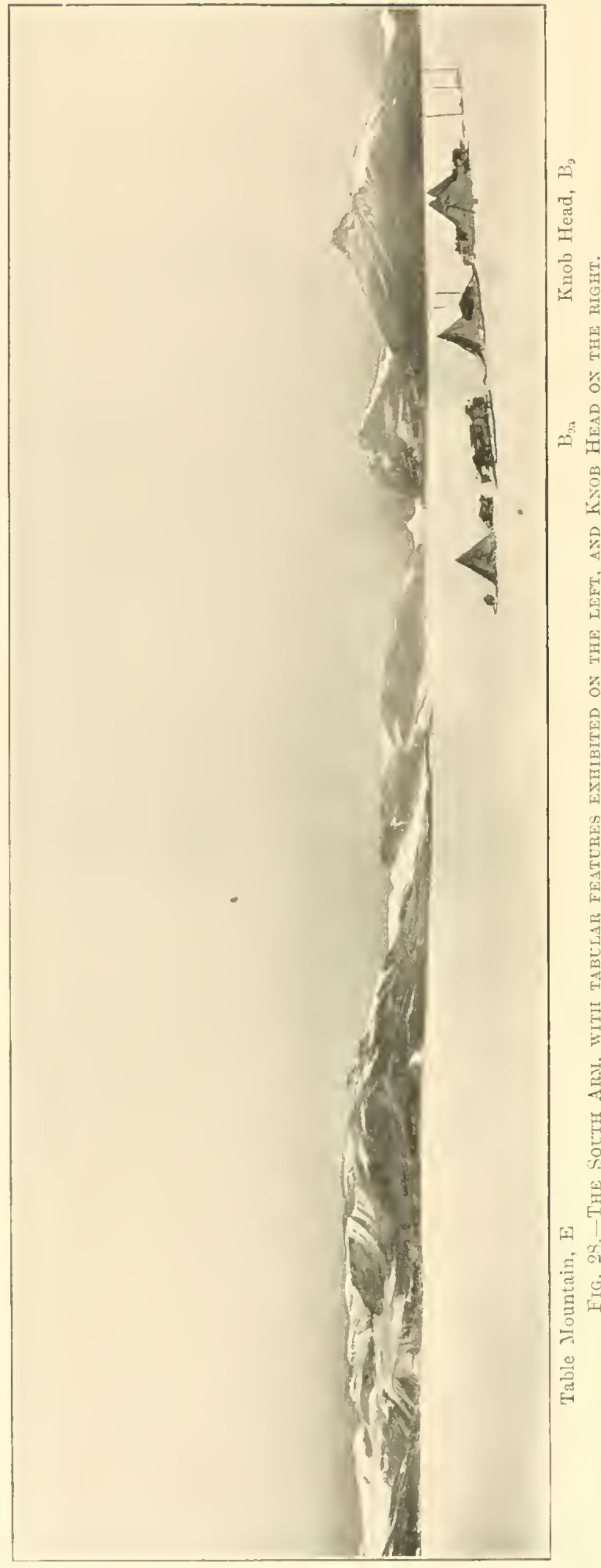

sandstone-dolerite anea is at least 50 miles long in a north-incl-south clirection, and has an extent of 2500 stuare miles at least.

I few of the hills in this neighbourhood, and especially the hill we called (Oberisk $\left(\mathrm{C}_{3}\right), 10$ miles east of Inland Forts, are pointed (Fig. 39, p. 7:) and resemble the hills in the Torriton Sindistone districts of uorth-west Scotlant; we may smmise that in these cases the "ip of dolerite is lacking.

In Granite Ifarlour a dark rock which weathers like columnar dolerite may be secu alove the granite (see 1. 32), and further up the coast to the north the higher pealis of many of the hills were formed of a dark rock and strood out in striking relief orer the Inland-ice agminst the doudless sky. The black tabular formation is most striking about latitude $77^{\circ} 0^{\prime} \mathrm{S}$., longitude $164^{\circ} 49^{\prime} \mathrm{F}$. and again in latiture $75^{\circ} 57^{\prime} \mathrm{S}$, longiturle $163^{\circ} 56^{\prime} \mathrm{E}$.

The area oreupied ly the Sandstone Formation is a ruestion still to be solverl. At the ontskirts of the area indiented above there seems to he no doubt the sandstone has an enormons thickness, roughly 2000 feet. Lientenant M. Baries reorels horizontal structures in latitule $80^{\circ}$ S., and Lientenant E. II. SHarkelaton has taken a photograph still further south which shows the plateau-features to be still prominent there. Towatro the north we need only mention Mount Nansen in latiunde $759.20^{\prime} \mathrm{s}$, and the pyraminal forms of the pralis of the Almiralty liange discussed above. 


\section{Chapter Tili. \\ TIIE SEA-ICE AND THE SIIORE-ICE.}

THE SEA-ICE.

Dupis: the winter months the surfaee of the sea in ligh latitudes often freezes in a uniform sheet which does not vary greatly in thickness. This covering has had many names given to it, but on the whole Sea-ice is perhaps the most suitable, as suggesting that the ice is derived lirectly from the sea.

Sea-ice requires to be distinguished from other loating iee (iee at sea) of different origin, and this can readily be done by the close examination of even a small fragment. The Structure of sea-ice has been dealt with by Dr. Axel HamberG, J) JoN DrvaAsist, $\dagger$ and others. Dr. von Drigadski rescribes sea-ice as being composed of bundles of fibres packed together perpendicularly to the surface of cooling. A point not mentioned by lim is, that, when the sea first freezes, the upper two inches consists of plates,

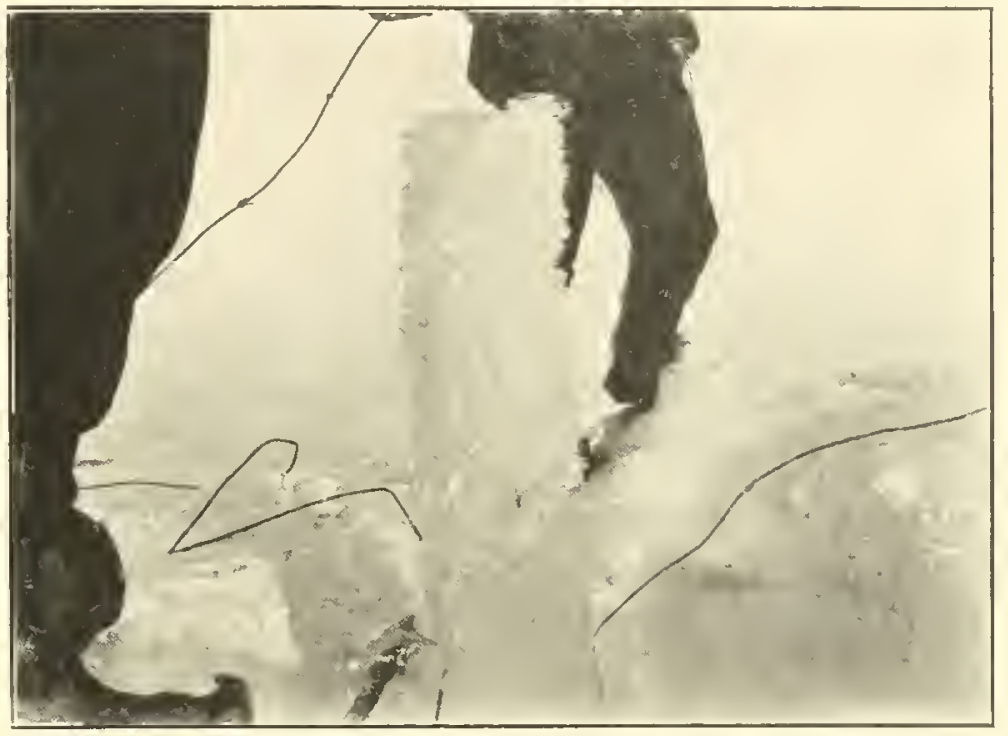

Fig, 29--Crestals of Ice whom hate grown upor a Fibmize Line SFVERAL FATHOMS BELOW TIE LOWER (OR FREEZING) SLRFACE OF TIIE SEA-ICE a quarter of an inch across and a sixteenth of an inch thick, which lie iborizontally, and only gradually do these give place to the sheares of vertical fibres which make up the greater mass of the ice. Between the plates and the fibres is a layer of ice, abont hilf an inch thick, of which the strueture is very confused. Fig. 29 shows a mass of ice-erystals which have grown mpon a fishing line. Mr. Hodgson recorts these erystals ats occupying a length of 17 fathoms of his line, and grarhally diminishing in yuantity from the surface downwards.

The Salinity * ${ }^{*}$ seems to depend more upon the rate of freezing than upon the depth or distanee from the surface. Both the anthors quoted above have mate

* Axel Hamberg, Hihang, K. Svenska. Vet.-Akad. Hantl., 1895, Bd. xxi, Aft. 2, No. 2,

† Trrgalski, 'Grönlinnd-Expedition,' 1897, Bd. i, 1). 424. 
observations in this eonnection, and have proved a great amount of variation. Our observations show that the variation is even greater than they have recorded. We may mention here that the arerage amount of salt in dry sea-ice is about $4 \cdot 3$ grams a litre, whereas $32 \cdot 8$ grams a litre is the average salinity of the sea.

Ice met with at sea is more variable, and the amount of salt contained in it depends upon the prerious history of the ice.

Near the shore, where floe-ice has buckled below the level of the sea-surface, shallow ponds form, and a gradual concentration of the dissolved salts takes place.

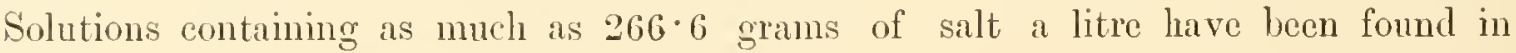
such pools.

When the open sea first freezes, part of the eoncentrated solution left yields well-crystallized rosettes (ice-flowers) on the upper surface of the iee. The rosettes

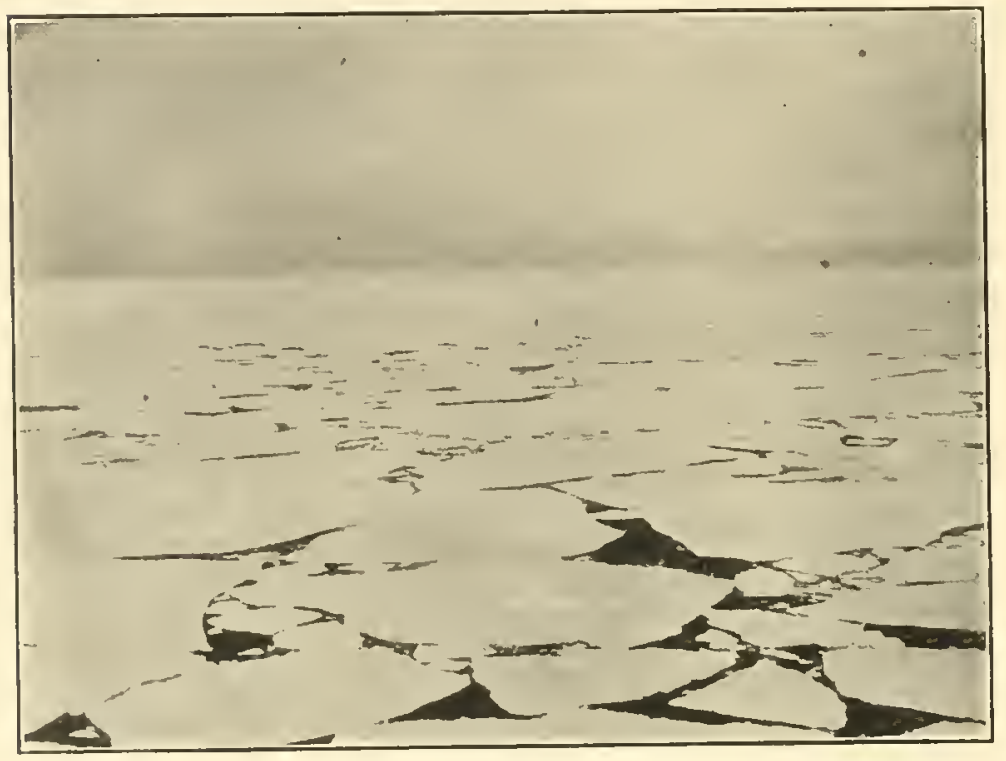

Fíi. 30. The PaCk-ICE, Seet from the Crow's Nest of the SHip. are usually two to three inches across and about an inch high and are seattered thirkly over the surface; they are always extremely saline. If the sea-iec becomes depressed by a great accumulation of snow, the original upper surface is still always capable of identification through this local first salt-concentrate.

The Snow on the seaice in MeMurdo Sound does not often accumulate to a thickness greater than two feet. Where any object interrupts the uniform level of the ice, snow-drifts form. The amount of the drift depends upon the magnitude of the olject; such an object as onr vessel produced a drift some 30 feet thick. The accumulation of local drifts has little ultimate effect upon the deptl of the lower surfice of the ice, for the snow, as it accumulates, pushes down the underlying layers into a region where the temperature of the water approaches that corresponding to greatest density; the lower ice then melts and is transported by the eurrents of the water (Fig. 49, p. 85). The equiralent of more than 18 feet of snow has been olserved to be removed by this means during two consecutive years. From this observation it would seem impossible that a very thick sheet of ice could be entirely built up through continued deposition of snow on sea-ice or oceanic ice.

At a hole near the ship the upper surfaee of the snow was three feet above 
water-level, and the original freezing surface of the ice had been depressed to four feet below water-level. The total thickness of snow accumulated at this spot during the two years was more than 20 feet; as the thickness here when the ice broke up was only 15 feet, the whole of the original iee and the earliest deposits of snow must have heen entirely removed by the melting action of the sea-water previous to the final break-up. By this means, water-vapour from low latitudes is condensed in high latitudes and transported again to low latitudes, without taking part in the glaciation of the polar land-masses.

Size of floes. Names* such as Pancake-ice, Bay-iee, Field-ice, Paek-ice, Stream-ice, are given to sea-ice at certain periods of its short life. Thus Pancakeice is the first product of the frozen sea. It is an aggregation into roughly eireular masses of the ice-plates which first erystallize. The that eakes thus formed are about an inch thick and one to two feet across, and have notably turned-up edges. In a sheltered bay where these cohere to form a thin sheet, the result is ealled Bay-ice. later, this thickening extends to large areas and the ice is then called Field-or Fast-ice. During the summer Field- or Floe-ice breaks up into floes, which float out northwards from MeMurdo Sound and join the belt of Pack-ice (Drift-ice, Treib-eis) eneircling the Antarctic regions (Figs.

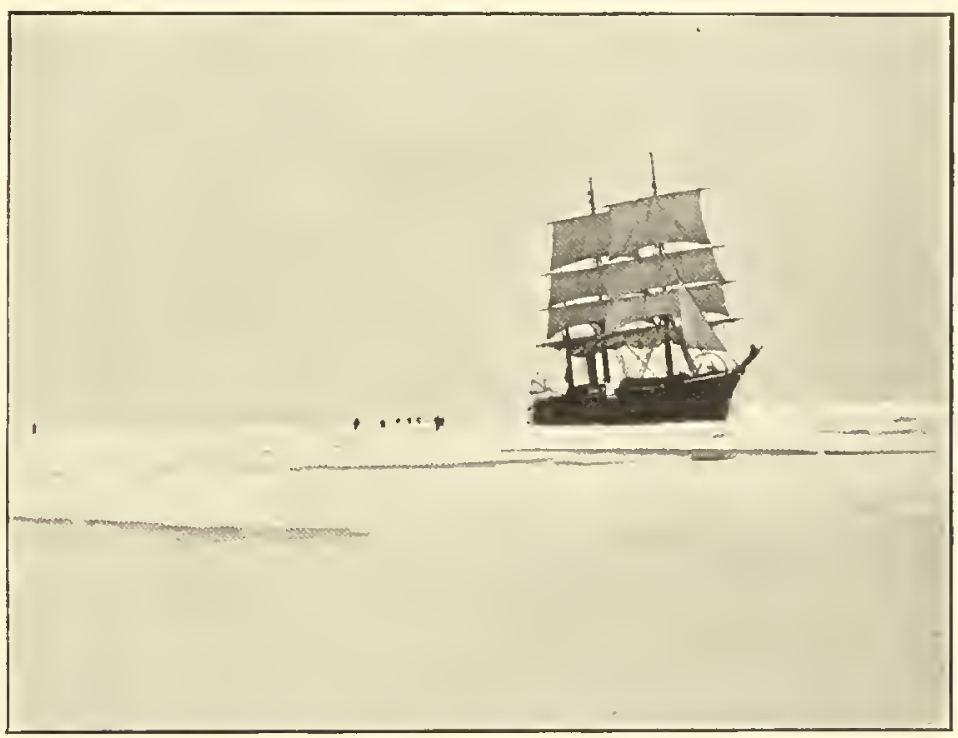

Fig. 31. The 'Discovery' Brought to a standstill by Pack-ice.

30, 31). As the floes drift north they break up and dissolve away, and they are met with at sea in elongate and seattered patches which are termed Stream-ice. The size of the floes varies greatly; one may be 100 yards across, another may be two miles or more, but the thiekness in the Ross Sea is never more than six feet. The floes are necessarily larger $\dagger$ on the south side of the belt of pack, as there they are protected from the swell by the stream-ice. Outside, the swell is most destruetive and rapidly breaks up any large ice-field.

Hummocks are rather exeeptional in the sea-ice of South Victoria Land, and all that occurred in MeMurdo Sound were less than three feet high. These seemed to be caused by the ice in the outer part of the bay breaking for a time

* Markham, 'The Antaretic Manual' (Roy. Geogr. Soc.), 1901, p. xiv; H. Rink, 'Danish Greenland,' 1877 , p. 73.

† Colbeck, Geog. Journ., 1905, vol. xxv, p. 403.

voL. I. 


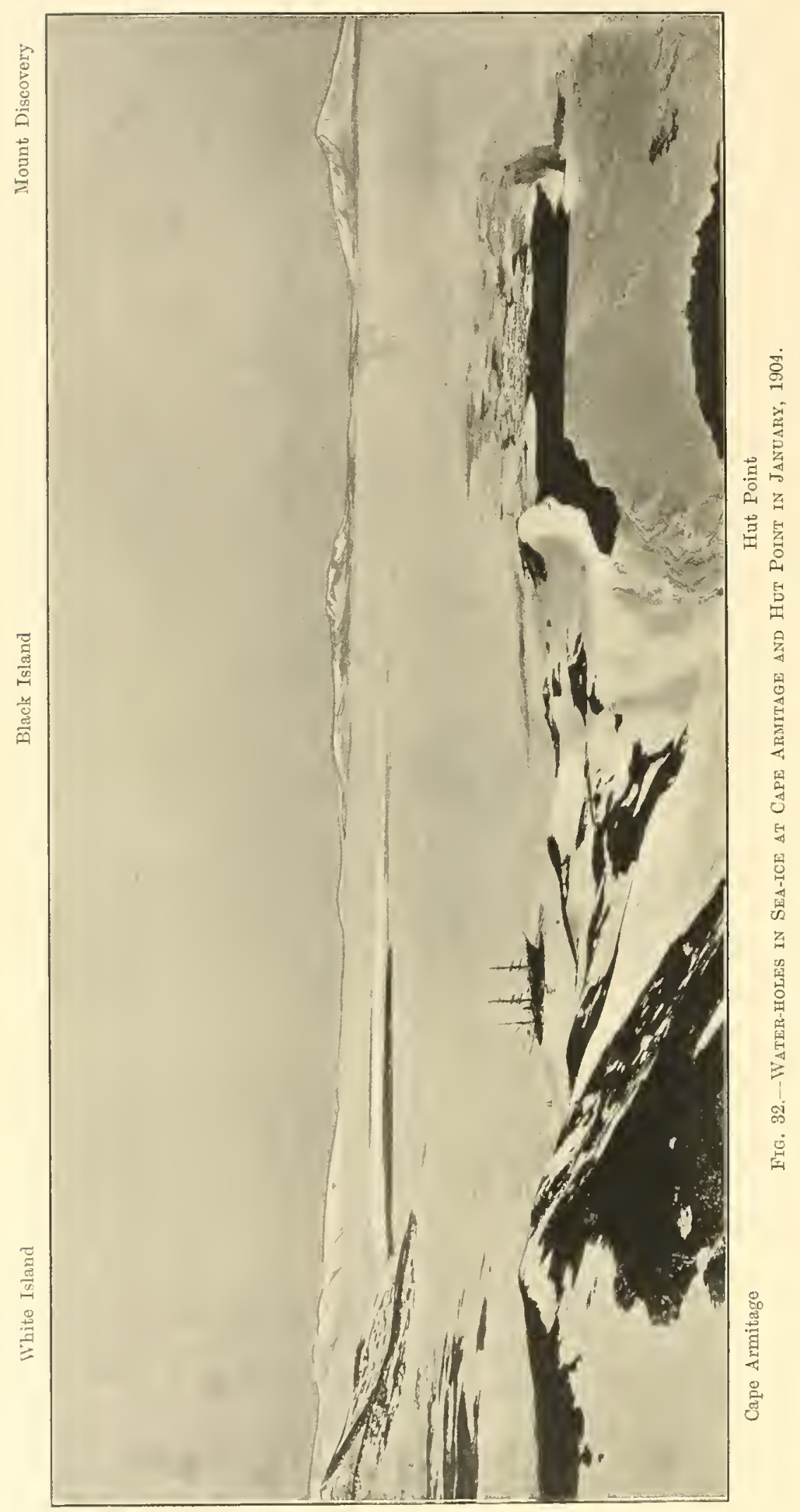


from the inner iee which is fixed, and then impinging on it again and again. In the belt of pack-ice, hummocks are rare and nsually less than 10 feet in height.

The Ross Ice-sheet presses against the sea-ice on the south-east side of the Winter Quarters peninsula, and produces a series of hummorks some two miles long. Some of the hummocks rise as bucklings of the sea-iee, here 8 feet thick; in otler's the sea-ice hreaks into pieces abont 20 feet long and these are foreed up on ent. Four parallel rows stretched out south-west from Pram Point and grew very gradually before the movement of the ice-sheet, only becoming conspicuous at the end of the first winter.

The Thickness.-The sea-surface freezes during the winter, but its ice rarely exceeds a thickness of 8 feet. Our observations on the thickness of sea-ice are rather exceptional for McMurdo Sound as a wholc; for in one case the ice-gange was placed where a strong eurrent was known to exist, and in the other case the ice-gange was placed in a sheltered bay, in ice which was always wind-swept and free from snow. At the former spot on March 1st, 1903, a water-hole was open: on the 24th of April the ice in it was 3 feet thick; and by abont mid-winter (June 27 th) it had grown to 5 feet. On August $23 \mathrm{rd}$ the thiekness was 6 feet 6 inches, and water

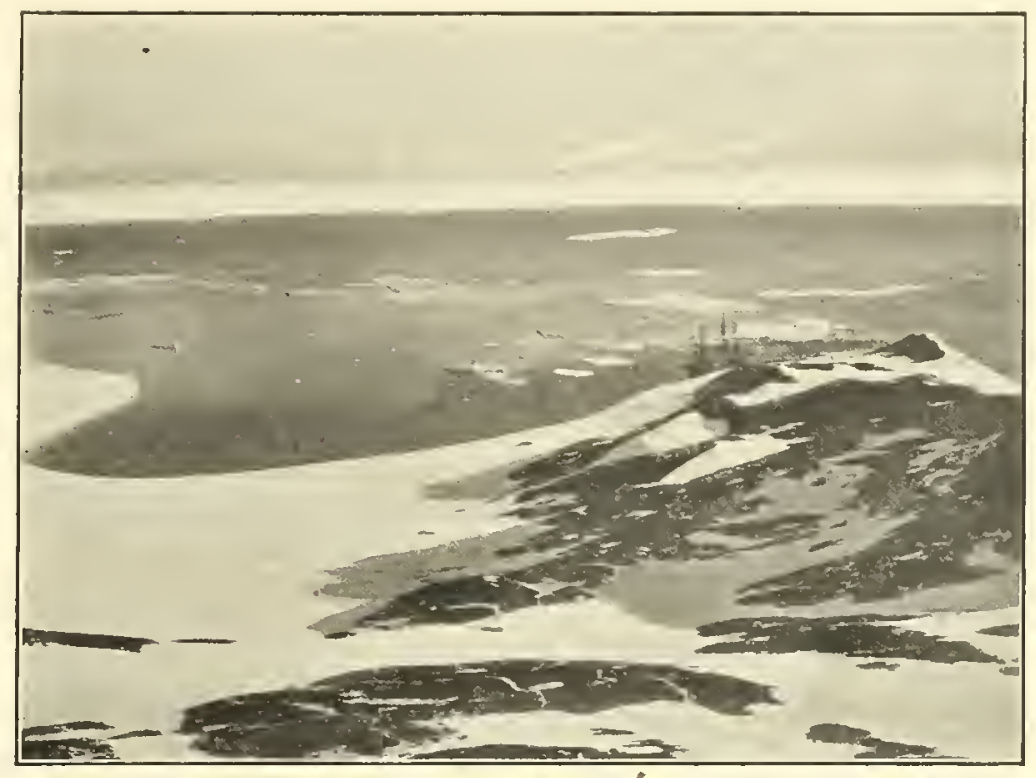

Fig. 33.-Sea-iCe Breaking aWAY From the Winter Quarters in 1902. continued to freeze until December 5th, by which time it attained its maximum ( 8 feet $5 \frac{3}{4}$ inches). After this date the ice legan to disappear from below, and by Jamuary 28th was all gone. A water-hole off Cape Armitage (Fig. 32) was observen to open each year, which shows this melting action of the sea on sea-ice to be important. In 1904 the ice which surrounded the 'Discovery' broke up naturally and rapidly floated away, and the rate at which the lreak-up took place seemed to be independent of the thickness (Figs. 33, 34).

Transport.-During the winter-months cracks in sea-ice, radiating from loth Hut Point and from Cape Armitage, were formed. These crackis are produect by the ice in the midille of the strait heing pushed forwarl faster than the ice at the sirles. The pressure is always in one direction, and is caused partly by the movement of the Ross Iee-sheet and partly by accumulations of snow along the shore. The cracks 
freeze up soon after they are formed, and no movement in the reverse direction can therefore take place. Cracks made in this way seldom open mueh more than two inches at any time, hut during the year have indieated a movement of more than 20 yards. Sea-ice therefore is removed in three ways: (1) through corrosion by sea-water, (2) breaking up and floating away piecemeal, (3) creeping bodily away from the land.

The "creep" of sea-iee is very small eompared with the movement which takes place when an ice-field breaks up at the end of the winter; but it is important, as it prepares the field-ice for the action of the ocean-swell which breaks it up during the

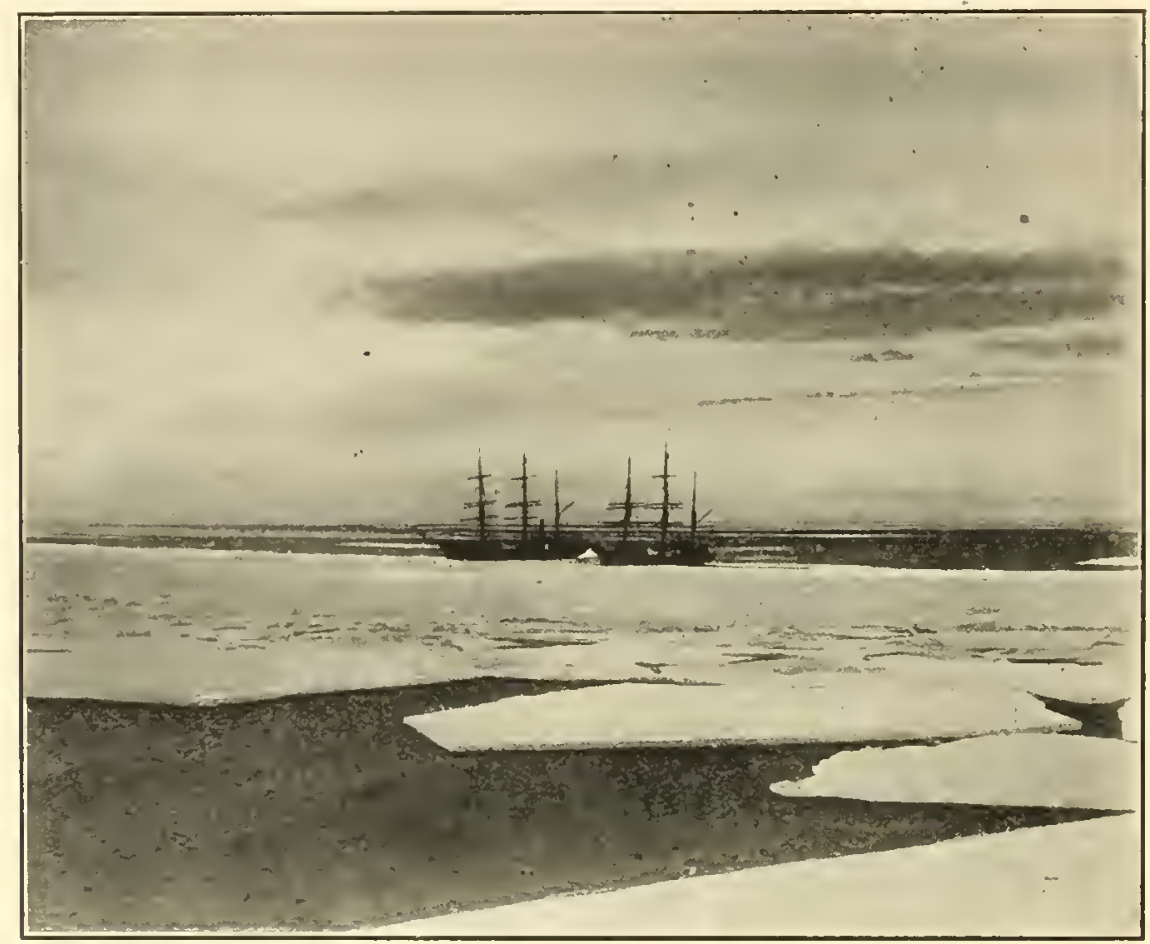

Fig. 34.-THE ReLIEF-SHIPS FORCING THEIR WAY THROUGH THE BARRIER OF FLOE-ICE IN 1904.

summer. As the field-ice breaks up, the floes that are formed drift northwards to augment the pack-ice.

Thenving.-Virtually no surface-thawing of the sea-ice takes place, for the air-temperature in the open is always fai below the freezing point, and the snow reflects most of the radiant heat. Locally dust and other extraneous partieles sink into the ice or snow, but the holes thus formed are. filled by the silting action of the snow. Mention has already been made of the action of the sea in redueing the thiekness of the floe-iee, and it is noteworthy that during sumny days the sea-temperature itself is slightly raised and then the water melts more quickly the ine at its seaward edge. This greater capacity for melting the ice las heen observed for at least two miles within the margin of the fast-ice of Medlurdo Sound. 


\section{THE SHORE-ICE.}

The shore of South Victoria Land is alwiys fringed with ice, which ends sharply seawards in a perpendicular wall (Plate II). The wall varies in height from

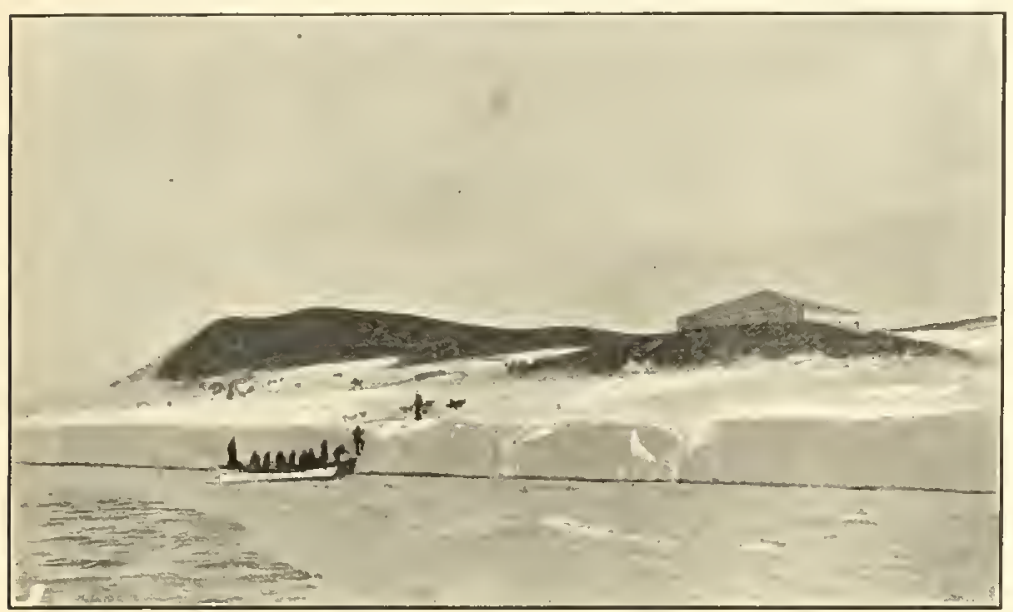

Fig. 35.-The ICE-Foot AT Hut PoINT.

3 to 300 feet, and two types of fringe may be distinguished.

(1) Fringe due wholly to the frozen spray. Such fringing ice never attains a lieight of more than six feet. The fringe of ice around the land in Granite Harbour is perhaps most characteristic, and forms a typical ice-foot.* It remained firmly frozen to the land all the year round. It is not materially alded to by snow-precipitation, and lissolves rather than increases during the few summer-days when the sea washes against it. As the maximum rise and fall of the tide is less than three feet, a low ice-foot, as contrasted with the high ice-foots of Aretie regions, is to be expected. The breadth of the fringe varies from 6 to perhaps 60 feet, and the surface, which is usually fairly Hat, often contains pools of water during summer. The chief action of the fringe is eonservative. $\dagger$ It proteets the land from the action of eroding breakers and floating ice, and more especially protects the rock-clift by cementing together its talus.

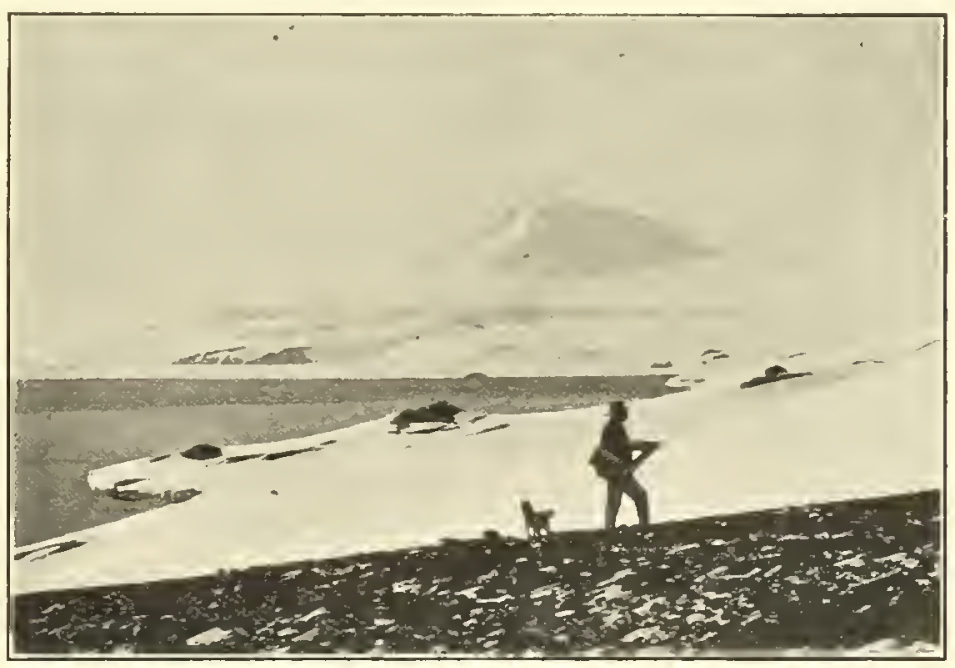

Fig. 36.-Shore-ICE Wrappixg the LAND NeAR THE FOOT OF CASTLE ROCE.

(2) Fringe of glacier-ice

adherent to the land (Figs. 35, 36). The ice is free from salt, shows the well-known blue bands, and has a well-marked granular structure. Such fringes vary much in

* Drygalski, 'Grönland-Expedition,' 1897, Bd. i, p. 285.

† Bonney, Quart. Journ. Geol. Soc.. 1902. vol. lviii, p. 699. 
their dimensions. The height varies from 6 feet to 300 feet, and the breadth from 10 yards to a mile. The surface usually dips at alout $20^{\circ}$ towards the ire-cliff:

As in the case of the first type, the action is wholly protective, but is even more effective owing to the greater size of the fringe.

A fringe of glacier-ice wraps the west side of Winter Quarters peninsula from the base of Mount Erebus to Crater Hill; near Castle Rock, where the ice-rlitf rearhes 300 feet, the fringe is perhaps at its highest.

Around Winter Harbour the cliff varies from 10 to 40 feet in height, and has a breadth which is sometimes as mueh as 100 yards; there, and in several other places, this type of fringe forms a sort of ill-marked terrace about 100 feet above sea-level, and slopes gently out towards its seaward face.

As in the case of glacier-terminations, it would seem that a lofty ice-rliff has always correspondingly deep water immediately adjoining it. 


\section{Chapter IX.}

\section{'T'HE LAND-ICE.}

The following classifiration of the land-ice of South Vietoria Land has been found convenient. The headings are largely taken from Dr. E. von DrYiaLski's 'Grönland Expedition,' and from Dr. Albert Heru's 'Handbuch der Gletseherkunde,' hut have been to some extent molified to meet local requirements.

(1) Icc-sheet, , or Inland-ice, ${ }^{*}$ is the name applied to a mass of ice which covers a continental area of land. In South Vietoria Land the sheets are of unknown extent, and enwrap and obliterate the inequalities of the interior land-surfaee, leaving coastal land-fringes comparatively free from ice.

(2) Local Iee-caps, $\dagger$ Hochlundeis, $\uparrow$ the ice rovering partially or wholly a limited land-mass. This ice may extend as an unbroken mass right down to the sea, or may uscape as iee-streams. Such a. cap may be defined as an ice-sheet on a small seale. These terms are necessarily relative, for we frequently speak of a polar ice-cop with reference to the earth as a whole, or again of a "lecel ice-cap," such as that upon Hayes Peninsula, quite a small area.

(3) Piedmont-glaciers $\$$ are formed by ice crowding on to a coastal plain at the foot of a mountain-range. In South Victoria Land three types are distinguished: (a) normal piedmonts-on-land; (1) piedmonts-aground; (e) piednonts-afloat.

(4) Gilaciors of Greenlund type, or Iee-streams, $\$$ drain an iee-sheet and end in the sea.

(5) Glaciers of Nomeginen type $\|$ consist of streams of ice flowing down welldefined valleys (fiords) from a large firufield.

(6) Glaciers of Alpine type, $\uparrow$ Talley-yluciers, drain small intermontane basins (firnmulden): seldom advancing far from their mountain-sourees, they never reach the sea.

* H. Link, 'Danish Greenland' (1877), P. 39 ; Drygalski, 'Grönland-Expedition,' 1897, Bd. i, Chapter 1V; Ileim, 'Handbuch der Gletscherkunde,' 1885, p. 51 ; Garwood and Gregory, Quart. Jomn. Geol. Soe., 1899, vol. 1v, 1. 682 ; Nansen, 'First Crossing of Greenland,' Chapters XV to XVIII.

† H. liink, 'Danisl Greenland' (1877), p. 366; Drygalsli, 'Grönland-Expedition,' 1897, Bd. i, p. 118; Chramberlin, Journal of Geology, 1895, vol. iii, p. 66.

‡ I. C. Russell, 'Glaciers of North America,' 1897, p. 2.

\$ H. Rink, 'Danislı Greenland' (1S77), p. 369 ; Heim, 'Handbueh der Gletseherkunde,' 1885, p. 51, ff.; Drygalski, 'Grönland-Expedition,' 1897, Bd. i, Chapter IV (Die Karajak-Eisströme mo ihr Nahrgebiet).

|| Ffein, 'Handbueh der Gletseherkunde,' 1885, p. 50 ; Drygalski, 'Grönland-Expedition,' 1897, Bd. i, p. 298, ff.

- Heim, 'Handbuch der Gletscherkunde,' 1885, p. 55 ; Drygalski, 'Grönland-Expedition,' 1897, Br. i, p. 298, ff. ; A. Geikie, 'Textbook of Geology,' 4 th chit., 1903, vol. i, p. 535, ti. 
(7) Cliff-glaciers, * Re-cemented glaciers, Glaciers remaniés are broken glaciers of the above types, which having a Thatreg, too steep in places to hold the ice, have areas of bare land separating the firnfields and the final tongues of ice whieh they produce.

(8) Hanging glaciers, $\uparrow$ Corrie-glaciers, Hängegletscher, are masses of snow and ice lying in cirques, corries or langing valleys. The ice in these disappears by melting, or by ablation, or by both proeesses, before the glacier can reach the main ice-stream.

(9) Ice-slabs are apparently peculiar to South Victoria Land, and are glaciers which, from the ecssation of ice-supply, have slipped away from their former firnfield.

(10) Tcebergs $\$$ are common to both the polar regions, and may be appended to this list as products of the breaking-up of all glaciers which reach the sea.

\section{The InIand-ICE.}

We have seen that the mountam-belt of South Victoria Land, quite 60 miles in breadtl, buttresses a firnfield of vast but unknown extent. This ice-sheet has a horizontal upper surface, which on the west of the Royal Society Range has an elevation of 7650 feet. It flows eastward through the range in a deep-sided valley which bifureates downwards in a most peculiar way. In the Prince Albert Range the flow passes between numataks, which are sometimes 20 miles long, in arms ten miles across. The numataks are usually broadside on to the present flow. The passes are shorter than they are hroad, and have a striking similarity to those on the west coast of Greenland.

In the ranges lying south of the Royal Society Range are deep and narrow channels termed "inlets" hy Captain ScotT. These channels are ice-filled, but lie much helow the level of the aljacent mountain-ranges and have very steep sides. A theodolite showed only a very slight rise in the horizon along these, so that if the IIinterland rises at all high it must lie many miles west of the coast. The Inland-iee flows through these channels to feed the Ross Piedmont or Ice-sheet.

The surface of the Inland-ice, where observed, consists entirely of soft snowpowler and shows no gradual passage through granular snow to compact iee. The soft snow-powder, being readily taken up hy wind and whirled about, is removed in bulk and transported hodily into the Ross Sea.

* Heim, 'IFandbueh der Gletseherkunde,' 1885, p. 58.

† Heim, 'Handbueh der Gletscherkunde,' 1885, p. 45.

‡ Heim, 'Handbuch der Gletseherlitule,' 1885, p. 273; Drygalski, 'Grönland-Expedition,' 1897, Bd. i, Chapter XIY.

§ Drygalski, 'Grönland-Expedition,' 1897, Bd, i, Chap. 1V. aud maps at end of vol, i. 


\section{LOCAL ICE-CAPS.}

The icy covering of Mount Erehus provides, perhaps, the best example of an Antaretic local ice-cap, and its features are exactly those of the Greenland ice-caps on a small scale. Snow covers the greater part of the area, ice-streams flow down between bare nunataks, e.q. The 'Turk's Head and The Skuary, and there is the bare coastal fringe between Cape Royds and Cape Barne.

The streams of ice which radiate from the mountain are too ill-defined to be called true glaciers. They have no snow-sheds, neither have they any well-defined banks. Still, all the mountains of Ross Island are completely covered with snow, and at definite points give off icebergs, which float away to the open ocean. The upper parts of Mount Erebus are covered by snow so thin that the ontlines of lava-streams near the summit can be recognised at a very great distance. The middle slopes have occasional patches of hare rock protruding through the snow, and rising up or dipping so steeply that snow cannot long remain upon them. The lower slopes are even more broken by hare lava, and the iee must always average less than 700 feet in thickness, for the ice sea-cliff is never more than 100 feet high.

The surface of Mount

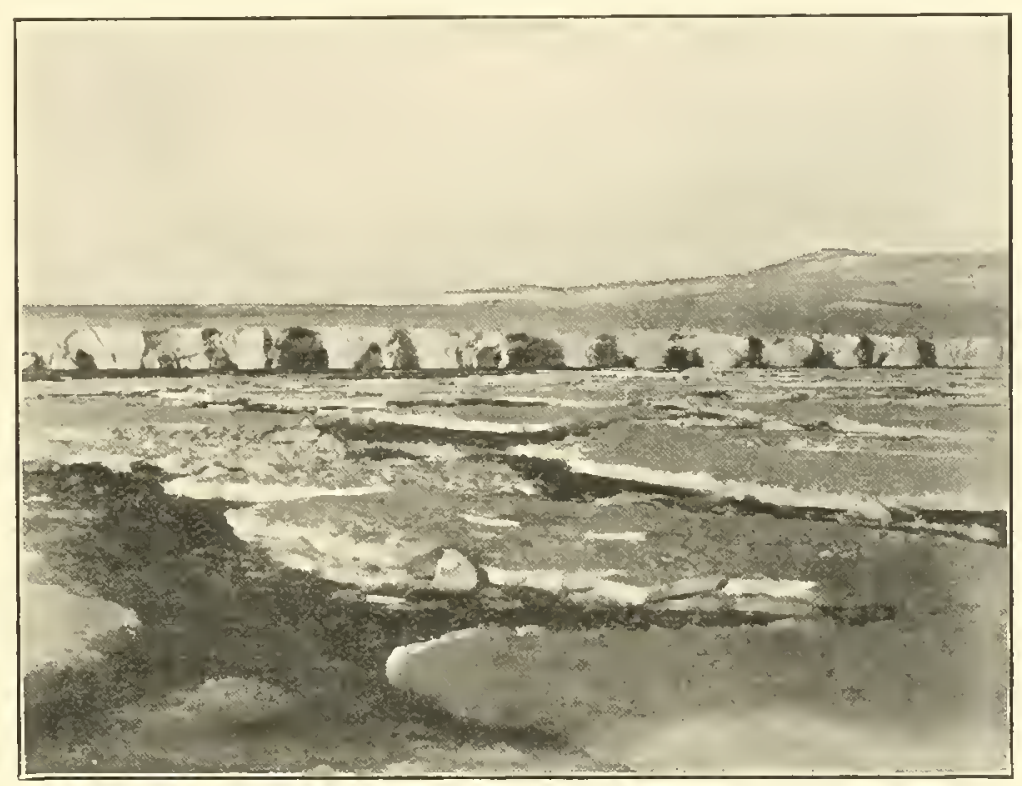

Fig. 37.-ICE-Foot and Pack-ice in Wood Bay at foot of MoUNT MELBOURNe.

Erebus shows numerous

ice-falls in which the crevassed ire-surface stands out above the level of the more even normal ice-covering. Mount Terror, Sturge Island of the Balleny Group, Couhan Island and Mount Mellourne, all form centres of local ice-shedding (see Plate I and Fig. 1 (p. 3), Fig. 3 (p. 5), Fig. 37).

\section{Piedionts.}

Masses of ice, which have a breadth greater than the length measured along the direction of flow, and lie at the foot of all large areas of high land, are conveniently refered to as piedmonts. These masses in South Victoria Land differ from such a

* I. C. Tiussell, 'Glaciers of North America,' 1897, Tacoma, p. 62, Fig. B. 
typical piedmont as the Malaspina Glacier* in that they are supplied by driftings and snow-cascades from the adjoining land-mass, whereas the Malaspina Glaeier lies below the snow-line and is only fed by distinct valley-glaciers.

Three types of piednont are distinguishable.

\section{(«.) Normal piedmonts, piedmonts-on-land.}

On the west side of MeNurdo Soumd, between the moraines and the Northern Foothills, there is a continuous ice-belt without apparent source of supply and lying wholly upon low land. This ice-belt occupies an area 10 miles long and 5 miles broad, and appears to be fed by the snow drifting over the lower passes of the foothills. On the west it covers the hills to a height of quite 1000 feet, but on the east it ends as an insignificant marginal sea-eliff less than 50 feet high. On the north it slopes sharply down towards the depression of the Ferrar Glacier, but on the south it merges into the Blue Glacier. On the whole the surface is eonvex, and slopes more stecply around the outer edge. The whole of the ice rests on land, and seems, by entirely burying the shore, to protect it from denudation.

Occasionally, along the base of the Prince Albert Range, the convex ice-slopes, such as the one discussed, connect definite ice-streams, whielı, strangely enough, are always at a lower level. From Cape Bernacehi to Granite Harbour, and from there to Cape Gauss, there are two notable unbroken stretches of iee-covered land. These areas may be regarded as series of land-piedmonts. Occasionally, eonspicuous seawashed rock-cliffs protrude through them, and the ice-cliff facing the sea is obviously the edge of a broken ice-lenticle. The length of the mass varies from 10 to 50 miles, but the breadth cannot be more than about 10 miles. The evidenee would seem to suggest that piedmonts are rather relics of a former greater ice-supply than products of the present conditions; their action would appear to be now entirely protective.

\section{(b.) Piedmonts-aground.}

Piedmonts-aground are well represented along the sides of Coulman Island, which has bare eliff-sides and a flat snow-eovered top (Fig. 3, p. 5). It is surrounded by a comparatively low ice-wall produced by a talus of snow, which drifts off the top of the eliff and accumulates along the eliff-sides to form a continuous belt. Sometimes the talus is a mixture of rock and ice, but as a rule rock-matter was conspicuously race. Small caseades of ice fall over the rock-cliff along the dykes and joint-cracks, which are schlom large enough to be called valleys.

This fringe has in section a convex npper surfaee. Near the rock-cliff it becomes steeper. At the seawarl erlge the convexity increases, and the termination is a cliff 100 feet ligh. Sections parallel to the shore would show a series of undulations, the crests being opposite to the main points of supply. Such fringes

* I. C. Russell, 'Glacicis of North America,' 1897, p. 109. 
as that of Coulman Island are sometimes as much as 15 miles long, but are rarely more than 2 miles broad. The snow encircles the rock-cliff up to heights of 200 to 400 feet above sea-level, and the seaward edge is not often more than 70 feet above water. The distinction between "piedmont-on-land," and "piedmontaground" is to some extent hypothetical, for it is difficult to make sure that ice at any particular point does not extend below sea-level (Fig. 56, p. 93).

On Sturge Island of the Balleny Group, a transition from "piedmontsaground " to "piedmonts-afloat" is also evident, for sometimes the undulating fringes flatten out along definite lines parallel to the shore and extend at least 5 miles out to sea, and so are probably partly afloat (Fig. 1, p. 3).

\section{(c.) Piedmonts-afloat.}

Piedmonts-afloat are represented by four important examples, (1) the sheet of ice which fills up Lady Newnes Bay, (2) the sheet at the foot of Mount Neumayer, Drygalski Piedmont, (3) the sheet which extends from Cape Gauss eastwards for 20 miles at least, Nordenskiöld Piedmont, and (4) the Ross Ice-shcet, or Great Ice Barrier of Ross. All these are characterised by great extent with flat or slightly undulating surface, and by a cliff-edge between 50 and 200 feet high, which has enough water immediately in front of it to completely Hoat the ice. 'The best known of these floating piedmonts is the ice-mass which Ross in 1841 called the Great Ice Barrier, but as this name entirely fails to convey the idea of vast extent, we conchude not to adopt it as a general type, but prefer rather to class the Ice Barrier of Ross and similar ice-masses as a subdivision of Russell's term 'Piedmont.'

The Ross Piedmont has a seaward edge some 500 miles long, and its terminal edge rises to an average height of 150 feet (Fig. 38). The depth of water close to this ice-face is usually between 300 and 400 fathoms, and the sea-floor is covered with fine rock-flour. If reference be made to the chart at the end of the volume, details of heights and depths along it may readily be seen. If it be assumed that aerated glacier-ice floats with at most six-sevenths of its volume immersed in sea-water, $\dagger$ we may take it that the height in feet of the sea-cliff above is equivalent to the depths in fathoms below, and hence that this ice-cliff must be afloat. Further evidence that it floats is afforded by the tide-crack around Mount Terror, White Island, and in many other places. The uniform horizontality of the upper surface was proved by Captain ScotT in his sledge-journey to the south, and by Lieutenant Royos and Mr. Bernacchi in their trip for 155 miles to the south-east.

The intimate structure of Piedmont-ice shows that as far as water-level it consists of normal glacier-ice. On the surface away from the land only fine snow was met

* I. C. Russell, 'Glaciers of North America,' 1897, pp. 2 and 3.

† Heim, 'Handbuch der Gletscherkunde,' 1885, p. 278, and H. Fink, 'Danish Greenland,' 1877, p. 358. 
with, but close to the shore crevasses and pressure-ridges show massive and vesicular ice. The vesicular ice eontains air * anomnting on the average to alout $8 \cdot 5$ per cent. of its own volume, and the ice-grains are usually less than a yuarter of an ineh aeross. Near White Island the grains are at least half an inch aeross and of a very uniform size. This oecurrenee, however, is exeeptional, for though no rumning water was seen, the patehes of hare ice are quite saturated with water, and it has already been proved by Herr EmDex $\dagger$ that growth of glacier-grains takes plice most rapidly at or near the freezing point. All observations marle seem to show

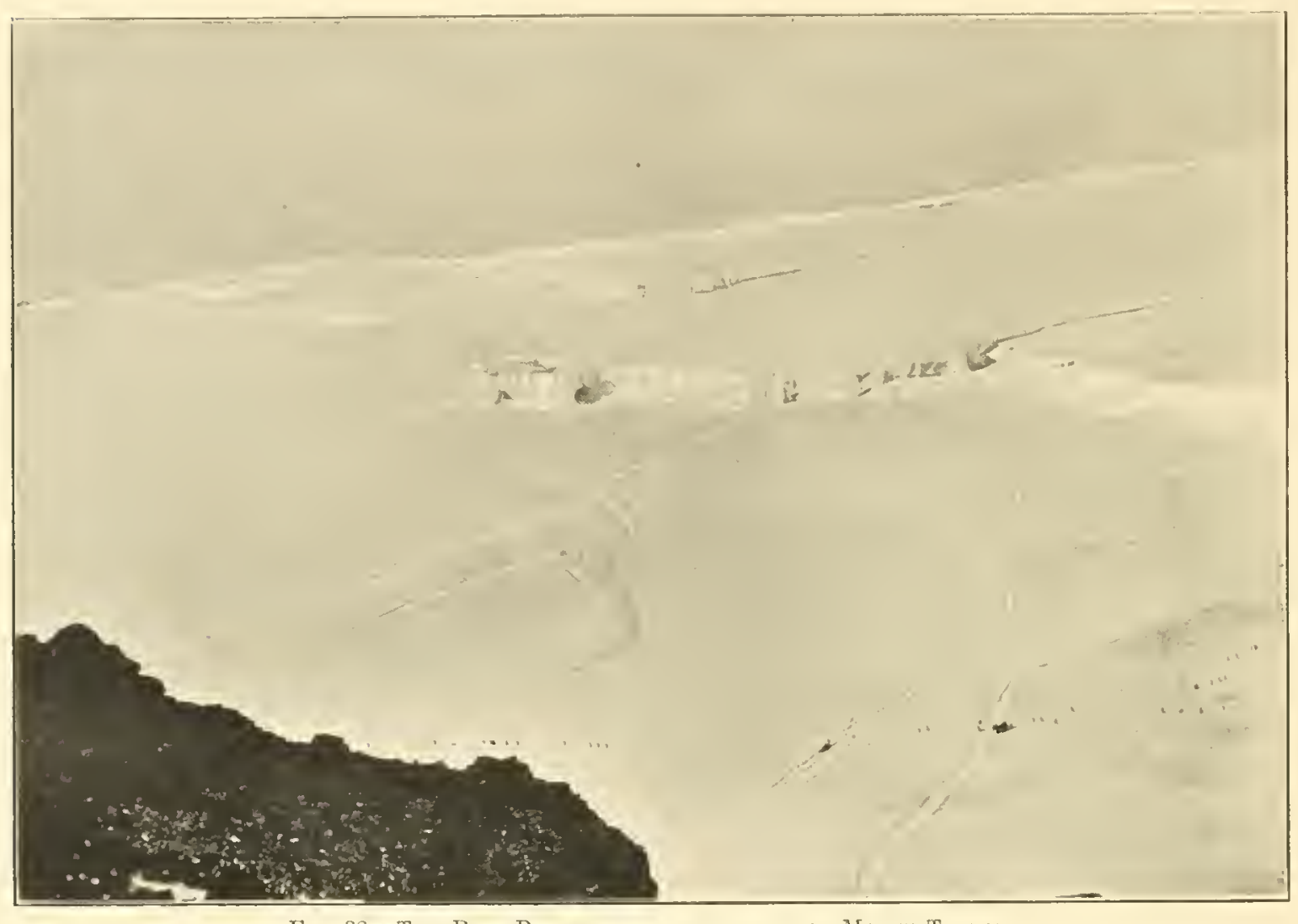

Fig. 38. - The Ross Piedmont from the side of ModNt Terror,

Showing the Cliff-tidge and Fiat Uppretr Surface.

that the Ross piedinont is produced ly ice-streams, not ahle to melt upon land, being pushed out to unite in a shallow bay, after which the iee-mass floats off towarls the deep sea. It is remarkable that along the whole elift-face from Cape (rozier to Cape Colbeck no trace of foreign matter in the ire could be olsserved. It the eastward end the land is completely buried in snow, but along the west side the land is comparatively bare. Rock-dénis was never met with more than a very few miles from land. The chasm t that skirts the west side is in itself suflicient to

* Heim, 'Mandbuch der Gletseherkunde,' 1885, p. 113.

$\dagger$ Enden, Neue Denkschr. schweiz. nat. Ges. 1893, Bd. xxxiii, Abth. 1.

‡ Scott, Geog. Journ., April 1905, vol. xxv, p. 366, plate. 
prevent boulders rolling on to the surface, but well-developed moraines on it are seen where, on Minna Bluff and Black Island, the ice hugs the shore. These moraines, however, will he discussed later; they are mentioned here as evidence that the ice-sheet does transport matter upon its surface. The movement of this piedmont seems to be comparatively rapid. Where measured by Lieutenant BARxe at Minna Bluff, it was proved that a point moved through 608 yards * in thirteen and a half montlis.

\section{Glaciers of Greeviand Type. (Plate III.)}

Under this head will be included such ice-streams as flow from the Inland-ice. In the Antarctic region this type of glacier is magnificently developed, and every gradation, from streams 5 to 60 miles long, and 5 to 10 miles wide, is to be seen.

The Prince Albert Mountains exhibit features so similar to those of the west coast of Greenland that one description would suffice for both. Attention may, however, be drawn to the fact that the Greenland ice-streams end in fiords and come lown between numataks free fron snow, whereas the ice-streams of the Prince Albert Range, though they may, perhaps, lie in fiords, project as if towards the edge of some coastal platform parallel to the mountains and well above the snowline. The nunataks are wholly encircled by snow-slopes which are rather higher than the ice between them. The Ferrar Glacier is the only one that has been entirely traversed. Situated as it is on one of the highest ranges of South Victoria Land, it can hardly be considered quite typical, though steep inlets, which break directly from the coast and back into the high mountains, are pecnliar to the whole region. The Fcrar Glacier has its source in the Inland-ice which lies at an altitude of 7600 feet above sea-level to the west of the Royal Society Range. The head of the glacier is an amphitheatre some 10 miles across, and is marked off by a few small numataks. The sudien rise to the Inland-ice is almost semicircular and stretches round from Depôt Nunatak to the North-west Nunataks, with a curve concave to the east. This concave curve is marked by two parallel ice-falls, each about 500 feet high. From the foot of this fall the ice monlds itself to the valley, and between straight, parallel, and almost vertical, rock-walls flows off eastwards. Near Finger Mountain the valley widens somewhat, the north wall continues its straight course, but the sonth wall recedes irregularly to the base of Knob Ilead, and in this way leaves the depression at the Solitary Rocks $\left(\mathbf{T}_{5}\right)$ through which the ice from Windy Gully and South Arm enters. The ice from South Arm splits on a submerged water-shed and part flows first westwards and then northwards into the North Fork, while the rest, considerably supplemented hy the discharge from the west of the Royal Society Range, fills up the East Fork, and eventually floats in the narrow fiord between the Lower Kukri Hills and the Northern Foothills.

\footnotetext{
* Scott, Geog. Journ., April 1905, vol. xxv, p. 363.
} 
At the same time, of the ice from the upper portion of the Ferrar Glacier, part flows round the south side of Solitary Rocks and unites with that from Windy Gully and South Arm; part ends short of the col between the Solitary Rocks $\left(D_{5}\right.$ and $\left.D_{5 n}\right)$ in a gradually attenuated tongue; and the rest, whieh hugs the north side, probably extends past $D_{5 a}$ to be joined loy that from the two tributaries from the south. Captain ScotT travelled down the North Fork, and tells me that the ice there ends in an insignificant cliff some 12 feet high, leaving the lower portion of the valley strewn with moraines and in part occupied by small frozen lakes.

At $\gamma_{1}$ the height of the north wall is not more than 1000 feet above the ice, but by about 10 miles farther eastward the valley-bed has fallen 1000 feet while the adjoining mountains remain at about the same altitude. The valley deepens continually; near the Kukri Hills it has fallen nearly 5000 feet below the mountains and is bare of ice. The south wall, west of Finger Mountain, averages 500 feet alove the ice, though the mountains are very mueh higher and culminate in the tabular mass 'T.

Windy Gully and South Arm also probably come down from the Inland-ice, which, about 20 miles further south, lies at an altitude of 7600 feet. The cañon-like form of the valley, therefore, is not so pronouneed here as in the North Fork. Where Cathedral Roeks face the Kukri Hill, the East Fork is 6 miles wide, and, having sides 4000 feet ligh, is remarkably cañon-like. It is about 20 miles long; further eastwards it passes into the long fiord (nearly 15 miles long) whieh lies between the Lower Knkri Hills and the Northern Foothills.

The surface of the ice is locally crevassed, and it is noticable that the crevassed areas, as on Mount Frebus, stand np ahove the general ice-surface. Crevassed areas are found: (1) in the middle of the glacier, six miles north-east of Depôt Nunatak; (2) close to the foot of Finger Mountain, where the valley-wall begins to retreat southwards; (3) close to $b_{2}$, where the ice is forced sharply round into the Dry Valleys; (4) on the south side of Solitary Rocks, where the ice enters North Fork; and (5) in the middle of East Fork, opposite Cathedral Rocks and three miles from them. Ilarginal ice-cliff's are a constant feature of the glacier, and moraines are rarely entirely alssent.

\section{Glaciers of Norwegian Type.}

The Norwegian type of glacier is well represented by the Blue Glacier reforred to in connection with the gneissic series of rocks. 'The Snow Valley, which lies parallel to the base of Royal Socicty Range, has at one time fed five or six valleyglaciers which Howed out eistward into Discovery Gulf. All except the Blue Glacier have leen loroken across by diminution of ice-supply; and the Blue Glacier, draining a very extensive firnfield, is so nearly stagnant that, where measured, it had not moved more than about three feet in the year.* Its length, measured from the 
point where definite banks begin to be evident, is some twelve miles; but, if measured from the foot of the mountain-range, is about double that amount.

The surface of the glacier is snow-eovered, and on the north side the snowdrifts of the foothills quite blend with those of the glacier-ice. No definite Bergselemel could be made ont. For the last four or five miles the north side of this glacier adjoins the land-piedmont described above; but here again no evidence of movement was seen. The sonth side of the glacier is bare ice, and below the hill $J_{1}$ erevassed areas, as in the ice of the Ferrar Glacier, stand in relief. Again, on the south side of the glacier-snout, the ice stands off from the land and leaves the conspicuous ehannel noted so frequently. The ice-wall adjoining this channel shows sections of enclosed dirt-bands and moraine, and these are speeially abundant in the lower part. As the cliff forming the snout is very clean and free from rock-deluris, such matter as is now being carried must be close down upon the sole of the ice. The Koettlitz Glacier may belong to this class, but little is known of its upper reaehes, and it apparently ends to the south of the Southern Foothills. At this point an ice-tongue from the Koettlitz Glacier breaks into the lower part of one of the minor valleys of the foothills, stagmates, and is no longer joined by the loeal glacier of the valley. 'The latter still exists as an ice-slab higher up. The main glaeier advances a little further along its main valley and feeds the floating ice of Discovery Gulf (see Plate VI).

Two glaciers flow into Granite Harbour and join at the sea-edge, but as their sources are unknown they also cannot be classified with certainty. They are peculiar' in that they too lie in narrow valleys which have very steep and straight sides, and from a distance are very like the Ferrar Glaeier. All these valleys lie approximately at right angles to the main trend of coast and mountain-range, and seem to be a charaeteristie struetural feature of the region. Glaciers of similar type are quite numerous among the snow-covered foothills of the Admiralty Range; some of them come down from valleys in the main range, while others arise in the snowfields of the foothills themselves. Into Robertson Bay flow some ten or twelve great glaciers which appear to drain the Inland-ice to the west of the mountains.* The Cape North portion of the mountains is traversed by at least two of the trough-like valleys carrying glaeiers, but as the whole region is eompletely covered with snow and iee it is not easy to distinguish the types of the glaciers.

\section{Glaciers of Alpine Type: Valley-glaciers.}

The most picturesque glacier of Alpine type is that of the deep and narrow valley between the hills $\mathrm{E}_{2}$ and $\mathrm{E}_{3}$ of Cathedral Rocks. This glacier is partly supplied with snow from the platean south of Cathedial Rocks. It is ahout five miles in length and one in brealth. It is erevassed from end to end. It joins the Ferrar Glacier about 2500 feet above sea-level, and eauses at least three transverse bucklings on the surface of the latter.

\footnotetext{
* Bernacchi, 'The Antarctic Manual' (Roy. Geogr. Soc.), 1901, p. 503.
} 
On the north wall of the North Fork, three glaeiers drain out of one finfichl and ent about 1000 feet above the iee of the main valley (Fig. .89). 'T'wo of these are cliff-glaciers, for the ire breaks off at the edge of a rlift and falls in avalunches which are lost in the main glacier at the foot of the clift. The third has lately been a eliff-glacicr, but its present loss by ablation exeeeds the supply, and it now ends some distance from the edge of the cliff and therefore is of Alpine type. The south side of the Upper Kukri Hills has a numerous series of hanging valleys distributed at regular intervals between $\mathrm{D}$ and $\mathrm{D}_{4}$. There are at least eight in a

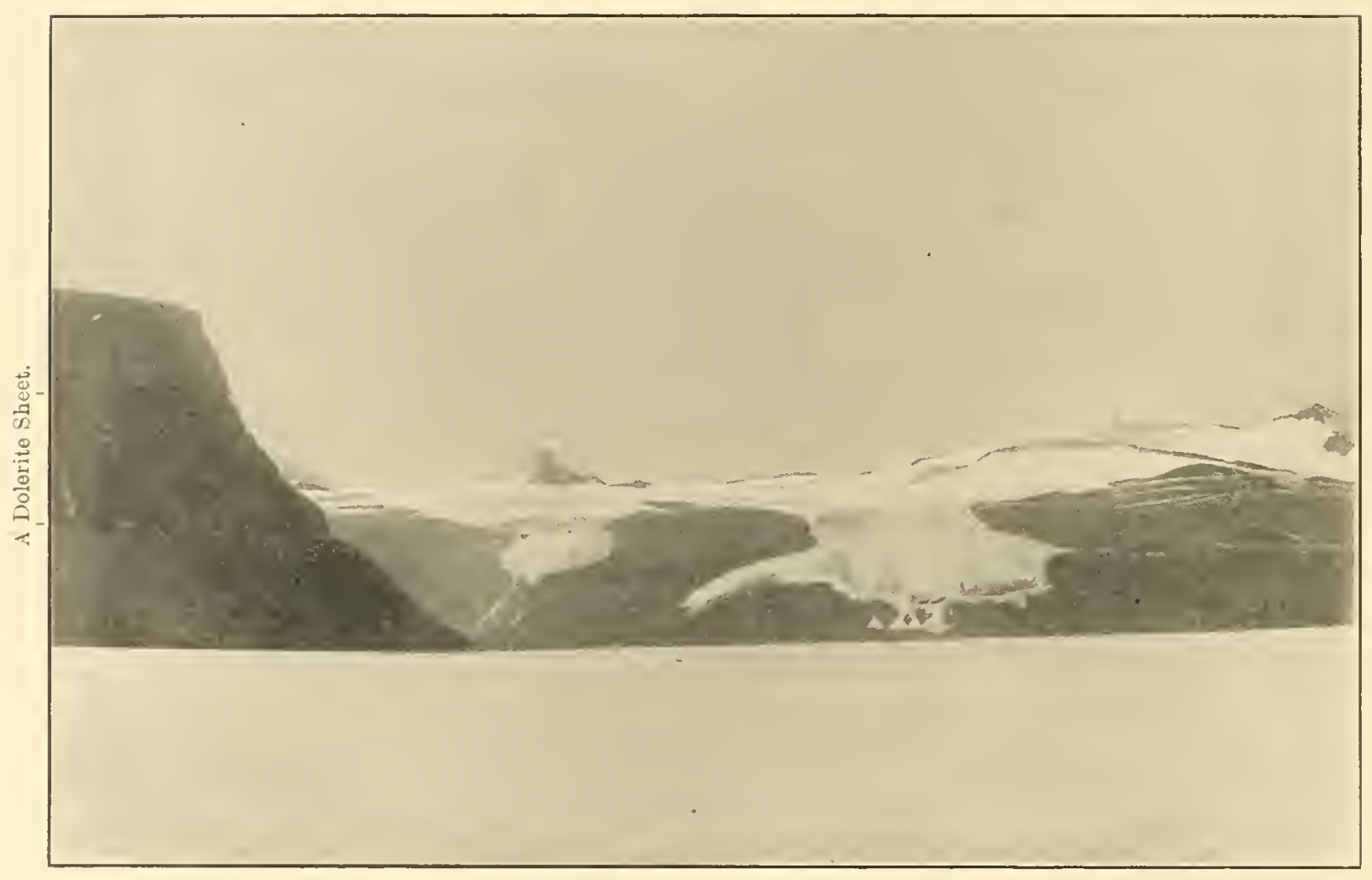

The Obelisk $\mathrm{C}_{3}$

Fig. 39.-Three Ice-tongues falling inTo NoRth Foris.

distance of 10 miles. Of the eight between $\mathrm{D}$ and $\mathrm{D}_{4}$, five have glaciers of Alpine type which, keeping their continuity, fall as easeades into the main valley below, and give rise to little or no disturbance in the latter.

\section{CliffF-(ilacikrs.}

The three other glaciers between D) and $\mathrm{D}_{4}$ are true Cliff-glaciers and, ending some 700 or 800 feet above the main glacier, discharge only as avalanches down the face of the clift. The wirth of these glaciers is usually less than a quarter of a mile. They extend most of the way down the eliff, which is here about 4000 feet high. The 
hanging valleys all hang about 300 feet above the ice of the main valley, and therefore at about 2000 feet above sea-level. In some of them the hanging lip is very evident, while in others the Thalueg is very nearly uniform all the way.

\section{Hlanging Glaciers; Corrie-glaciers (Fig. 20, p. 42).}

Four Corrie-glaciers are worthy of mention. These lie on the south side of the Inland Forts and oecupy the cirques below the culs which link up the Forts. Three of these glaciers are quite isolated, but the fourth is joined by a tributary from the west side of Round Mountain $\left(\mathrm{C}_{1}\right)$. All flow southwards, but fail to reach the ice of the main valley, and are now building up erescentic moraines at their terminations. The interest of these glaciers lies in the fact that, though they now flow southward, they were formerly foreed northward by the Ferrar Glacier into another drainage-system. Their supply is local from the Inland Forts, and the cols at their heads are completely bare.

\section{ICE-slabs (Plate VI).}

Ice-slabs are found in all valleys on the east side of the Southern Foothills of the Royal Society Range. These slabs are masses of ice, four to six square miles in extent and about 50 feet thick. They are the relies of glaciers which once drained the Snow Valley; but, owing to diminution of ice-supply, this has now become an inland basin, and its overflows have slipped away from it, leaving a subsidiary watershed bare. The surface of the icc-slabs is quite clean, and free from mud or stones. It is convex and slopes gently outwards from a centre. The ice-cliffs which bound ice-slabs show abundant dirt-bands and scattered morainie matter in their lower parts. In each valley in the Southern Foothills there is a glacier of this type, and it would seem that their development is due to the peculiar forms of the hills and their surroundings.

\section{ICEBergs (Fig. 40).}

Icebergs have been defined by Hem as masses of glacier-ice floatiug in the sea. They are common to both polar regions. The icebergs of South Victoria Land are usually tabular in form, and the vast majority seem to be derived from some common source. Shore-ice is not prolifie in the formation of bergs, as such ice remains firmly fixed to the land throughout the year. Blue Glacier was under observation for over sixtcen months, and during that time no berg broke away from it, the snout remaining firmly frozen on to the sea-ice from the year 1902 to the year 1904. Within a mile of Blue Glacier, however, five bergs were aground, and could only lave been derived from it. 
If no iec-stream moved fister than does the Ferrar Glacier the number of hergs would be almost negligible. Doubtless the numerous ice-streans crossing the Prince Albert Mountains must give rise to a certain number of bergs, but even then the number is probably small. The piedmonts-on-land, lying on a flat shore and receiving only a small supply of snow, can seldom provide enough ice to form iechergs. Cliffs that encircle shore-ice hold snowdrifts which are sometimes as much as 60 feet thick. These always float out to sea during the summer, and produce small bergs which may easily be mistaken for the broken-up masses of

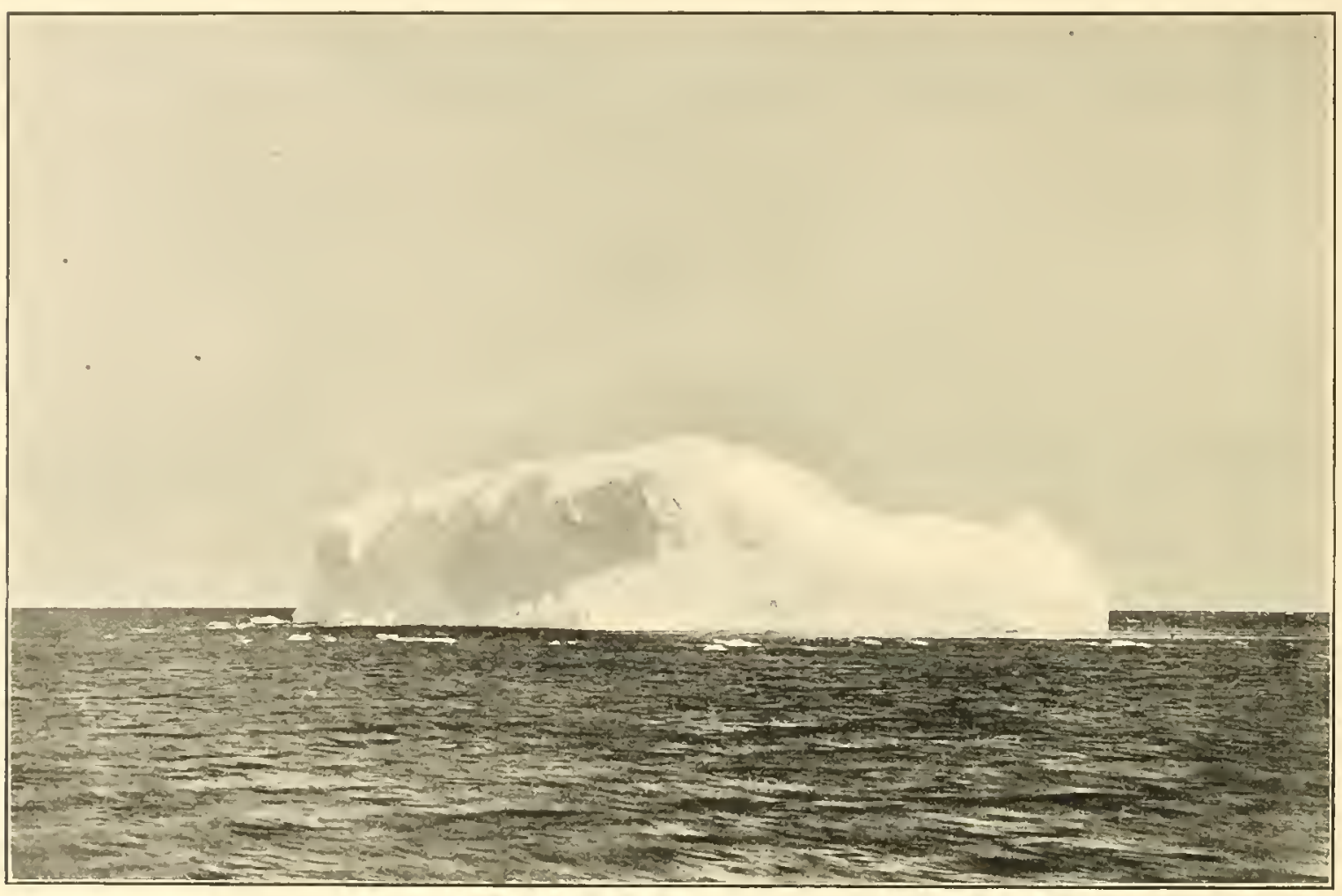

Fig. 40.-AN ICEberg, Oter 150 feet high, tilted throtgh NeArly $90^{\circ}$.

tabular bergs. Piermonts-aground do appear to produce icebergs which have irregular shapes and are produced in the manner of text-book icebergs.

On the Balleny Isles, where the snowfall is much greater, the piedmonts ereep furlher out to sea and therefore supply larger bergs. It is, however, to floating piedmonts that we must ascribe the great majority of Antaretie bergs, and when we remember that the edge of the Ross Piedmont, whose ice is advaneing northwarl faster than any other ice in Soutl Vietoria Land, has lost a belt averaging 15 miles in wilth during the last sixty-five years, we see that it must have given lise to innumerable bergs.

Piedmonts-afloat, from their configuration, can only supply tabular bergs, and the sizes of these vary enormously. Although the Ross Piedmont rises over 200 
feet above sea-level, bergs over 150 feet high were seldom seen. Most bergs are less than a quarter of a mile long and about 70 fect high. The largest bergs scen were near King Edward VII Land, where there were many over 150 fect high; they had grounded in plaees where soundings showed 100 fathoms of water. Local ice-eaps supply few bergs. Mount Melbournc, for example, has its ice-rlifts caremous and overhanging, and we mat conclude that years have clapscd since bergs separated from them (Fig. 37, p. 65).

Distribution.-Icebergs float northward along the coast of South Victoria Land bearing with them their burden of mud and stones, and soundings scem to show that most of this is dropped within the Antarctie Circle. In latitude $67^{\circ} \mathrm{S}$. the sea-floor proved to consist of mud and ice-scratched stones, whereas only diatomooze had been obtained in the deeper water of latitude $60^{\circ} \mathrm{S}$. The distribution of bergs in latitudes which are being constantly navigated is represcnted on the Admiralty Ice-ehart, No. 1241, and a short paper by Mr. H. C. Russell gives some measurements as to the sizes of the bergs. For our purpose, however, the northerly migration along the coast is the point of interest; the long string of bergs grounded ncar Cape Adare seemed to have formed a banner-shoal; melting there, they must deposit the moraine brought by them from higher latitudes.

Ieebergs are destroyed by two agents, the sea and the sun. Some bergs float north into the warmer waters of more temperate latitudes and are there quickly melted. As the berg is undermined by the wirm sea-water it beeomes top-heary and sometimes turns over, large pieces being broken off in the process. Some bergs ground in high latitudes and are only slowly dissolvel. At certain stages these may float off the shoal and go to swell the mass of drifting ice.

Bergs eontaining mud, sand or gravel absorb radiant heat, and some ice is melted. The water produeed distributes the mud over the surface and the rate of destruetion is increased; on December 'th, 1903, a hot day, a herg was seen to have rivulets over all the sides turned towards the sun. A berg hecoming inverted may earry mud and stones from the sea-floor above water, and these the sun immediatcly utilizes for the disintegration of the berg. In latitude $77^{\circ} \mathrm{S}$, thawing of ice is of little importanee exeept in December and January. Melting begins in the miklle of November, becomes comparatively lapid by the middle of December, continues through January, and virtually eeases about the middle of February.

* H. C. Russell, Journ. Foy. Soc., New South Wales, 1898 (1S97), vol. xxxi, p. 221. 


\section{Chapter X}

THE LAND-ICE-continued.

Englucial rock-débris may usually be seen near the terminal ends of glaciers. It oceurs in well-defined bands interlaminated with bands of almost pure ice. The ice-walls which form the edge of a glacier also show rock-matter, and, as near the

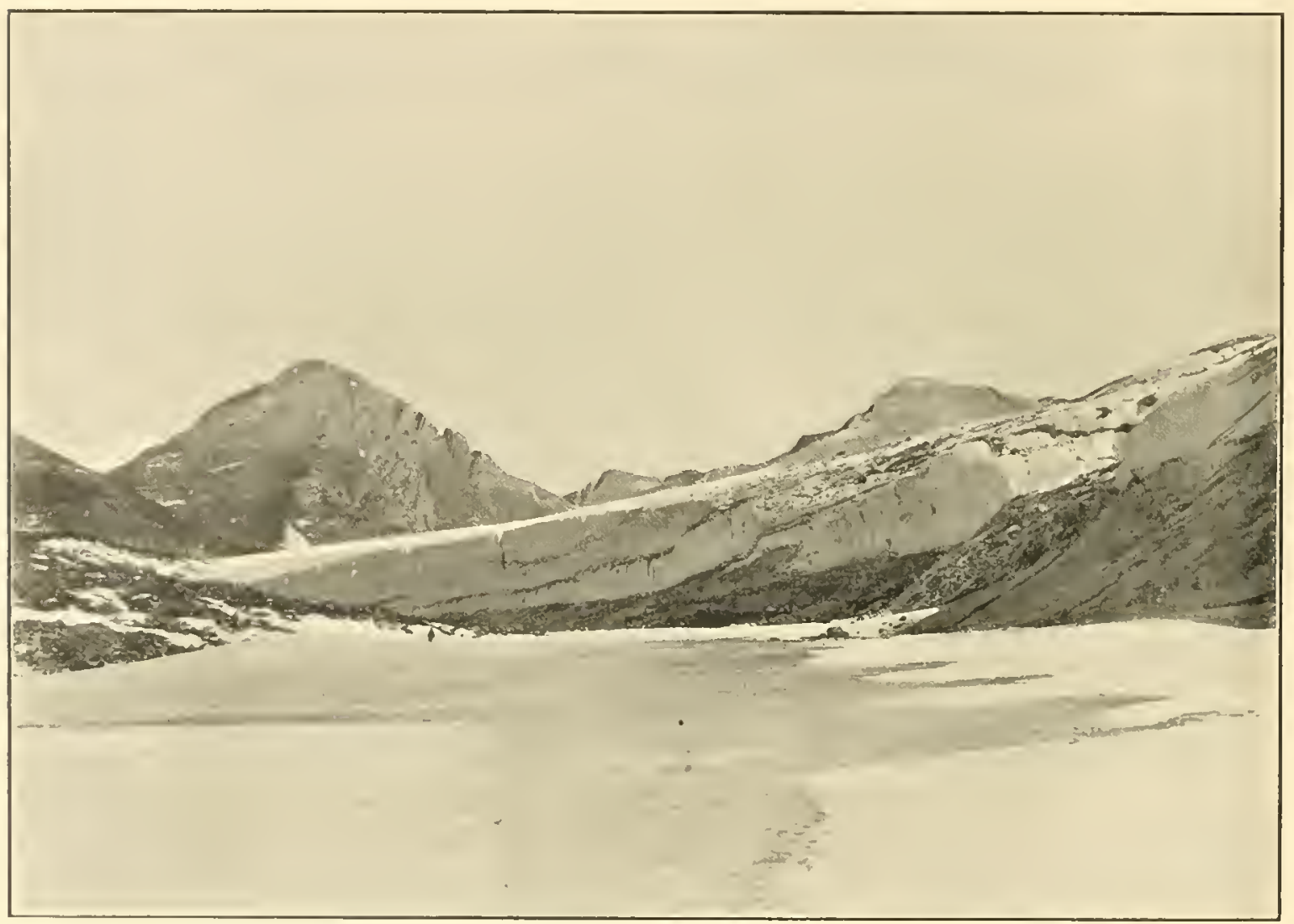

Fig. 41.-Uplift of Moraintc Material in the Ice at the foot of Kinob Head.

snout, the rock-matter is more abundant in the lower layers. In the upper reaches of the Ferrar Glacier, the ice-cliffs though 100 feet high show only occasional small stones, lout in the middle reaches, e.\%, at the hase of Knob Head Nountain, boulders up to four feet across were olserved low down in the ice-eliff. These houklers are ice-seratched and suh-angular: they are mixed with numerous small stones and some sand. At this spot also two streams of ice meet, and at their junction the englacial matter is forced up 70 feet and appears as a normal medial moraine (Figs. 41, 42). 
Below the hill $\mathrm{D}_{4}$ the chasm between ice and rock is only about 50 feet deep and some 30 feet wide. The lower 20 feet of the ice-cliff is heavily charged with rock-détwis of all shapes and sizes. Rounderl and apparently water-worn boulders up to 12 feet across are exuded from the ice, together with fime sand and mud.

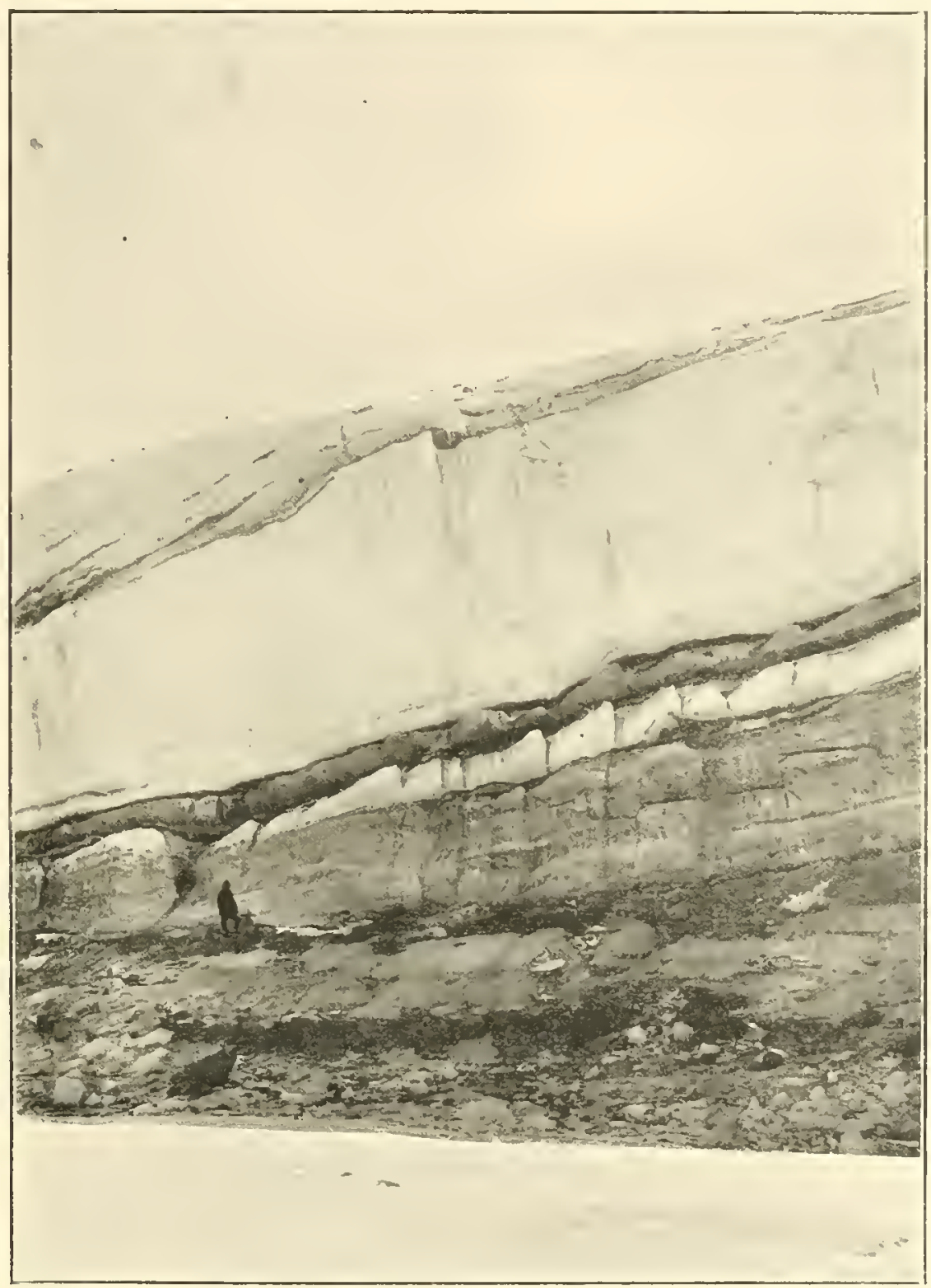

Fig. 42.-The DaRK Baxd of ICE-Mithott-Grain, Below NorMal GLaCier-ice, AT THE FOOT OF KNOB HEAD.

The sun is wasting the eliff away so rapidly that a lateral moraine is appearing below the general level of the glacier, and a small stream flowing along it is carrying away the finer material which is being dropped into it by the rapidly thawing ice. 
On the south side of the snout of the Blue Glacier and 50 feet below the upper surface, there occur a chamel and ice-clift', like those of the Karajak ice-stream figured by Dr. Drifatski; * along the rhannel, binds of mud and stones are visible in the ice-cliff. In one of the ice-slalbs of the Southern Footlills sandy englacial matter occurs in much the sime waty as in the Irory Glacier of Spitzherger.†

Supmeglacial meter is remarkably searce. In this respeet the glacier's of the Antaretic region stand in contrast with those of Switzerland or New Zealand. The latter are so much covered with angular rock-délnis that no ice can be seen within three miles of the actual snout. The lateral and medial moraines on the Ferrar Glacier are not often as regular in distrilution as moraines of other regions. Sometimes they begin suddenly about five miles from the nearest rock-exposure, and, after extending some

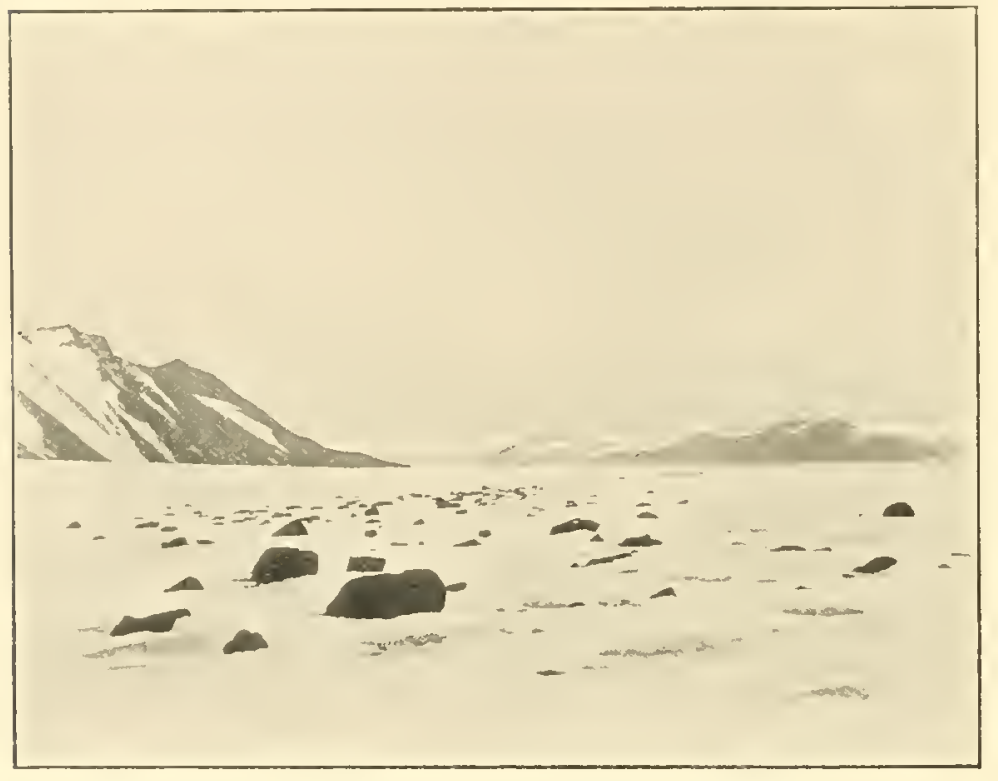

Fig. 43. - Moratne on the Ferrar Glacter.

Kuliri Hills on the left, Granite-H1Lls $\left(\mathrm{G}_{2}, \mathrm{G}_{3}\right)$ ON THE RIGHT. way down the valley, end as suddenly as they began. Again, thongh bare rocks, surh as Depot Nunatak, shower talus upon the ice, the moraine profluced can only be followed some two or three miles down the valley. In the Dry Valleys, the moraines appear to be melting off and to be falling back into the channels hetween ice and rock. A few isolated morines are also souttered at random over the surface of the invading Ferrar Glacier:

The moraines which are brought down by South Arm are perhaps the most striking in the region. Five of them are very prominent. One in the midcle of this tributary extends north past the base of Knob Jead, then turns for a time northwest, and finally curves round to the north-east, and on entering the North Fork is lost. Two pairs of moraines, mather nearer the east sile of the glacier, bend romel into East Fork and following the ins and onts of the valley, erentually find their way on to the floating ice at its mouth (Plate IIl). This double pair, as seen from J lescent Pass, lorks like the single priir of wheel-tracks of a watgon, but, as a matter of experience, at least half a mile of bare ice separates one pair from the other:

\footnotetext{
* Drygalski, 'Grönland.Expedition,' 1897, Bd. i. plate 14, p. 64.

$\dagger$ Girwoor, Quart. Journ. Geol. Soc., 1898, rool. liv, plate 16.
} 
The moraines consist of three-foot houlders of dolerite, granite and sandstone, which are accompanierl by very little fine material (Fig. 43). The moraines are 30 feet wide, and the boulders are scattered thickly over the whole width. At the base of Cathedral Rocks another moraine commences and accompanies the other four. They prodnce parallel furrows in the surface of the ice which increase in depth as the boulders disappear. Ahout I0 miles cast of Cathedral Rocks these moraines are still represented by the parallel depressions, but the boulders are few and isolated, and numerous patches of coarse-graincd ice mark the positions of those which have sunk through. Out on the floating portion of the Ferrar Glacier the boulders are even more scattered, and solitary survivors, about 100 yards apart, are all that represent the moraines of the upper reaches.

It was among these moraines, at heights between 3000 and 4000 feet, that we found numerous mummified earcases of the crabeating seal (Lolodon carcinophagus). These are interesting in that the movements of seals ashore are always slow and laboured; how they could have travelled 40 miles uphill over rough ice and soft snow is an unsolved mystery. A pecten shell was also met with in gravel 10 miles up the Ferrar Glacier and 20 feet ahove the sea. The gravel

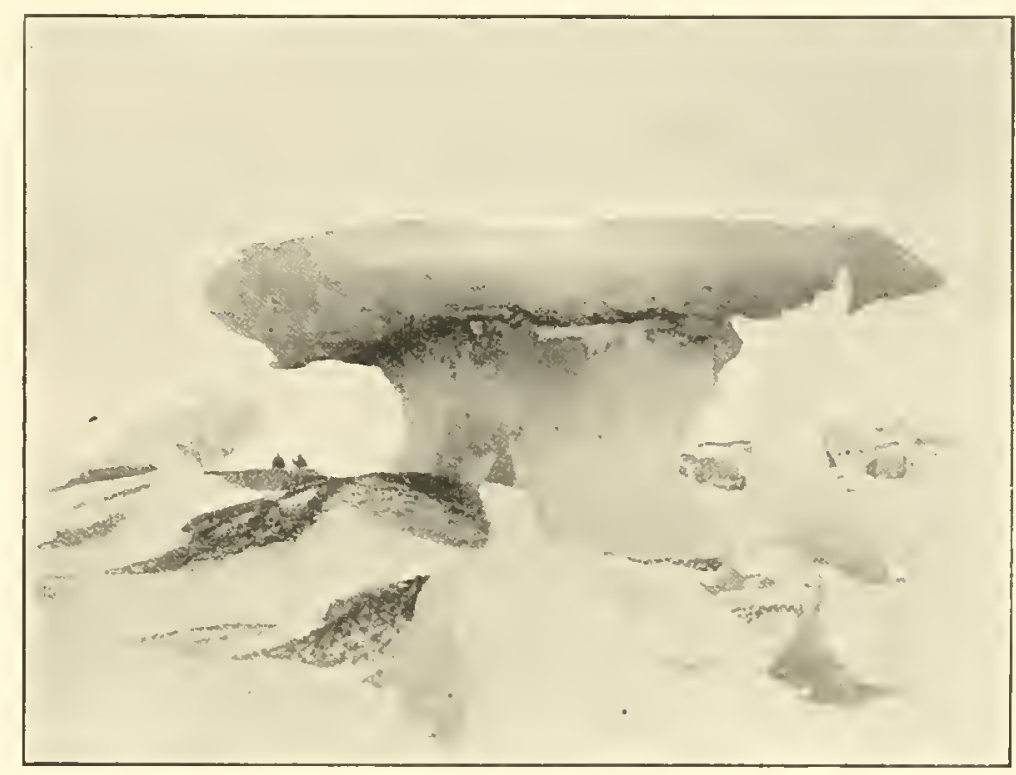

Fig. 44.-Glacier-table forded bi a Layer of Gravel. had formed a glacier-table (Fig. 44), and the ice around was all glacier-ice, but is not above the reach of some exceptional tidal wave.

On floating ice at the head of MeNurdo Sound there are great quantities of moraine (Figs. 45, 47); the latter completely covers the ice and malies it difficult to make sure that this great mass is really afloat. There is, however, the tidecrack, which, following the land-boundary, marks off this détris-strewn area as a stagnant but floating mass. Onr observations seem to show that the ice is really an overflow from the Ross Piedmont. In Discovery Gulf, also, the surface of the Hoating ice carries much rock and some organic $(512,513)$ débris, and extends for a distance of more than 20 miles from land. Between Black Istand and Brown Island the morainie matter is unworn, its stones being usually angular. The moraines occur in long trains of cones which often rise 50 feet above the general 
level of the ire. Sometimes the cones blend with one another, and produee a series of ridges whose direction follows the former direetion of movement.

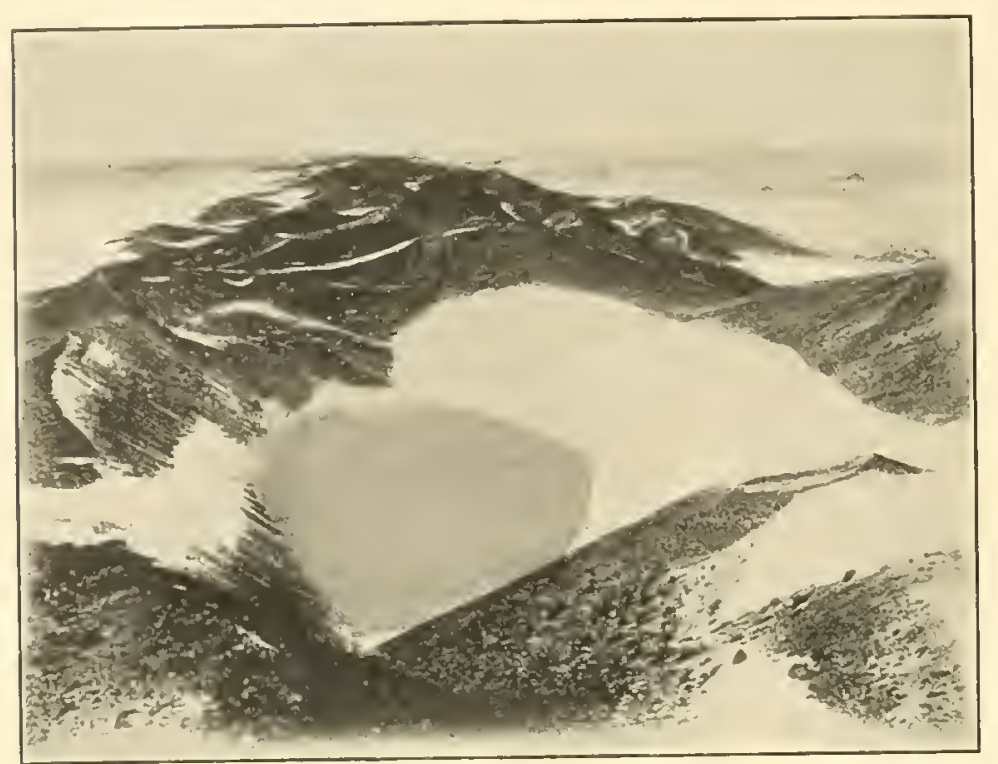

Fig, 45. - Jloraines on Floating Ice at the Head of Micilcrdo Sound.

On rounding the north end of Black Island, the lines of cones curve westwarl, and alle further continued northward to the "pinnacled ice" or old iceedge. Occasionally large houlders up to four feet in diameter are found, but these disappear and are replaced by great quantities of coarse sand (261), which is often blown about by wind. It is this sand which, by inducing melting, produces the rivulets. These give rise to the fantastic "pinnacled ice" which presents so insuperable a difficulty to the sledge-traveller.

Re-sorted morcines were observed at Cape Adare; the "beach," from which so varied an assortment of pebbles has been taken, is one mass of such moraines. The average height of the beach is about 20 feet above the sea, but only 30 yards of the northern fringe hats recently undergone modification by water. In detail the beach consists of parallel series of ridge-and-furrow with amplitude of about four feet. The ridges curve with the rockwall. Sometimes the fine material appears stratified, but the covering of pebhles usually hides all evidence of structure. The.ridges, which are occupied by penguins, flatten morthward; and the depressions which contain stagnimt water sometines join up and form large digitating ponds. It an elevation of more than 800 feet on Cape Adare are other moraines. 'These cross the peninsula to the

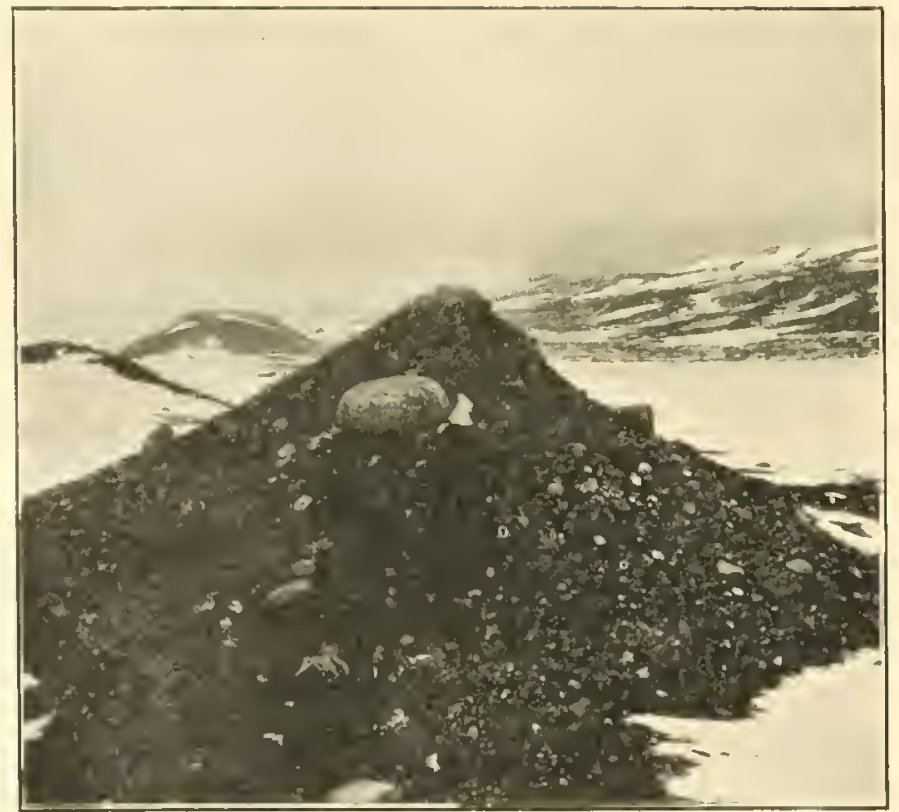

Fig, 46. - Moraine-conf of ICE-SCratcined Stones, on witch the Balantes Shelles were found, on tire flodting Glacier-ice in the bay letween Whith lstand and Beack Island. 
north-east; they consist of small stones, some ice-scratehed boulders, and a few blocks of rock up to 12 feet across. The beaches of Possession Island, Nood Bay and Franklin Island, appear to be similar to the Cape Ardare beach.

Stranded moraines also oceur above Cape Crozier on the slopes of Nount Terror at heights of 300 to 500 feet. Others on the south-east sile are rery striking. They lie 800 feet above sea-level and are 200 or 300 feet above the level of the Ross Piedmont. Other moraines oceur on that shoulder of Mount Erebus which terminates in Cape Royds. They occur up to a height of 1000 feet, and are very well seen near the 800-foot contour. They cover some three square miles of area. Granites, and rocks like the dolerites of the Royal Society Range, are the most conspicuous components.

The moraines on the west sile of McNurdo Sound are developed on a larger scale than any other moraines in South Victoria Land. An area there, 5 miles by 3 , is one mass of détris-cones, some of them being as much as 100 feet ligh (Fig. 47). These cones rest in some cases upon land, in other cases upon fixed ice, and occur on a flat which is not more than 4 feet ahove the sea. The cones are more or less in lines, and the lines appear to radiate irregularly from two points, one set of them converging near the snout of Blue Glacier. Though the cones rise considerahly above the cuge of the land-piedmont described on

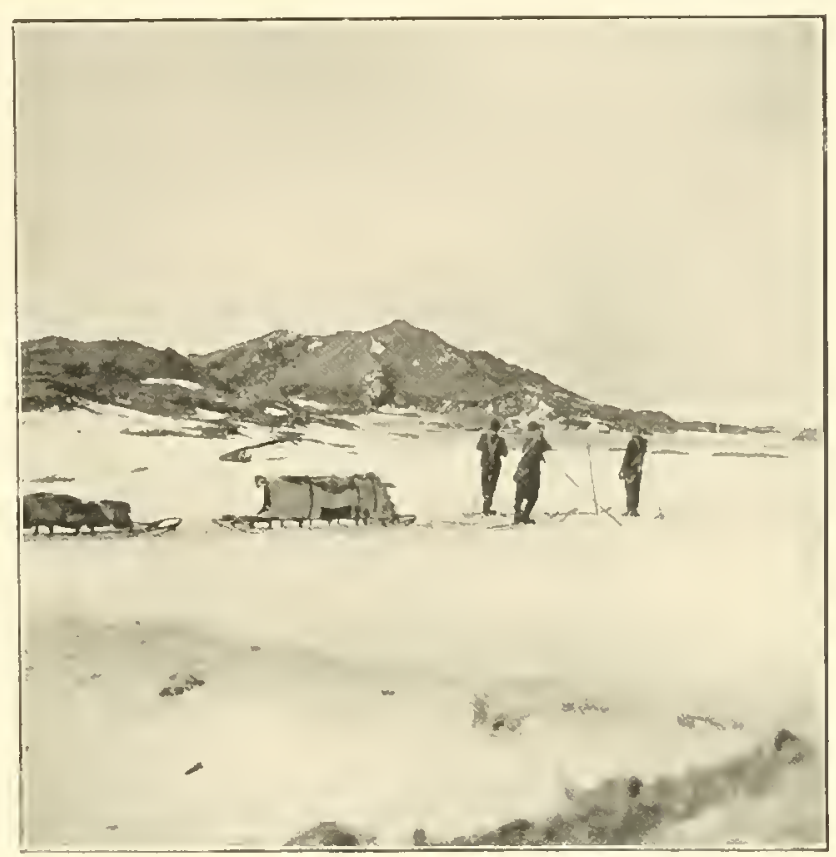

Fig. 47.-MIORAINes SUPTORTED BI ICE, ON THE WEST SIDE of McMundo Sotrid.

p. 66, they follow its eastward borler.

On the south side of Blue Glacier these cones are replaced by a continuous line of moraine, and this hugs the edge of the Southern Foothills for a distance of some 30 miles.

Before leaving the subject we must lniefly mention the ice which supports the cones and occasionally protrudes through the covering of débis. In particular cases it is often impossible to say what part of the material is ice and what part is rock-débris, and hence no attempt has here been made to distinguish betwecn moraines still being carried by ice and moraines now resting upon the land. Even on Cape Royds water oozing from some of the ridges showed that the latter contained ice. During summer the fine material is continually being separated from the coarse by the water from melted ice (Fig. 52, p. 89). In some cases, however, the cloak of détris is too thick to allow the heat of the VOL. I. 
summer sun to get through, and the ice beneath it may then be preserved almost indefinitely.

The eharneteristic sheer iee-walls bounding the glaeiers of South Victoria Land show that under present eonditions the sides are receding from the land. The intervening chammels often contain frozen ponds, which in some eases, though only 50 yards broad, are more than a mile in length. The large pond at the base of Knob Ilead may be eontrasted with the Nlarjelen See, in that it follows the straight side of the main valley instead of merely occupying the dammed-up end of a trilutary valley (Fig. 41, p. 76).

The structure of the ice between the bands of intra-glacial material at the lase of Knob Head show's remarkable variations. The uppermost 40 feet appears to be quite normal resicular glacier-ice and is free from rock-débris (Fig, 42, p. 77). Below this are several notable dirt-bands, and among them other bands from 2 to 10 feet thick, perfectly clean, and clear as rock-crystal. On melting small fragments from these bands no granular structure could be seen, and it is suggested that they are, in part at least, due to intrusive thaw-water. Other bands showed air-vesicles elongated at right angles to the loanding. The iee which contains the majority of boulders has a structure eomparable to that of ordinary rock-fault lreceias, and it would appear that the ice here glides forward as a series of rigid sheets along parallel thrust-planes.

Up-threst of morainie material similar to the up-thrust in Spitzbergen described hy Professor Carwood, * was also observed at Depôt Nunatak, where Beacon Sanłstone boulders are brought up to the surface. Up-thrust was again in evidenee behind the Solitary Rocks on the Ferrar Glacier. Up-thrust produced by impact of two streams of ice is further seen at the foot of Knob Head, where the dirt-lands with large boulders bend up and appear on the surface 70 feet above their usual position (Fig. 41, p. 76).

lee-movement.-Owing to the great distanee whieh separated Winter Quarters from any glaeier, our observations on the rate of iee-movement have been few in number. The rate at which the ice from South Arm forees its way into Last Fork of the Ferrar Glacier is probably less than six feet per month. Other olservations made at its snout indicate that the rate is extremely small. The Blue Glacier moves less than four feet a year, while the Ross Piedmont, as measured by Lientenant BARNe from the depôt off Minna Bluff, moved no less than 608 yards in $13 \frac{1}{2}$ months. 'The movement of Ferrar Glacier or Blue Glaeier auses little disturbance of the sea-ice; shight movements are transmitted to the latter and beeome lost in its more ordinary movement. Where the Ross Piedmont abuts against Mount Terror, three parallel and well-defined rilges appear. These are at least 50 miles long and usually some 50 feet high. They have heen traced by Lientenant Royds towards the north end of White Island, hut gradually flatten ont and fan. At Pram Point fon lines of parallel hummorks, each about 15 feet high,

\footnotetext{
* Garwood and Gregory, Quart. Journ. Geol, Soc., 1898, vol. liv, p. 219.
} 
are caused by an overflow of Ross Piedmont. Captain ScoTt found that the iee of sneh chanuels as Mulock Inlet pushes the piedmont-ice away from the land and leaves a ehasm,* some 100 feet deep, in the intervals between them. At such outstanding points as Minna Bluff, eracks and crevasses radiate outwards, partieularly towards the east and north-east; but a sledge-party, by giving the land a wide berth, was able to avoid most of these. Near the north end of White Islaud also, series of radiating eracks are found. It would therefore seem probable that the Ross Piedmont is moving northwards bodily.

The ice-falls of Ferrar Glaeier indicate movement, but, as the erevasses always remain drifted up with snow, the rate must be exeeedingly slow. In the channel at the foot of Knob Head, where the evidenee of up-thrust is reeorded above, the banks of the frozen ponds lave several small ridges alongside and parallel to the glacierside. These ridges, which are oceasionally broken along their length, indicate a certain amount of movement; as this is the only spot where rupture eaused by shearing movement is obvious, the fict is noteworthy.

Near the sea, where the ice-tongue floats in its valley, the tide-crack follows the side of the glacier for a distance of at least 10 miles. Near the foot of the hill $\mathrm{G}_{2}$ the crack trends towards the centre, and, gradually disappearing, is replaced by other aracks which trend inwards up the valley. It would seem that the point of replacement indicates the floating of the iee, and that the oblique cracks show a slightly more rapid forward movement of the mass of iee behind.

In the amphitheatre or depression of the Ferrar Glacier, two miles from the foot of Knob Ilead, the ice shows a network of ribbon-like cracks or fracture-lines (Risse $\dagger$ ). These are often less than two inches apart, and, without opening more than a hair's breadth, extend for great distances. Parties eamped on this ice have observed on several oceasions that very rapid splitting or bursting asunder takes place with loud report, as soon as the hills cast their shadows on the ice. The reports which accompany the splitting are loud and frequent, and often resemble the noise of independent rifle-firing. The noises frequently eontinue for an hour and a lalf at a time. Rupturing has also been olserved at several other spots, and seems to be eaused by strain set up by chauges of temperature in the ice. That the ice is in a state of strain is proved by the fact that a blow from an irou-shod ski-stick has produced cracks which have extended 50 yards across the surface of a mass of ice not less than 100 feet thick.

Snorv.-The usual accumulation of snow took place during violent blizzards when the air became thick with fine snow-dust (Fig. 48). On a few oceasions in the summer, however, large tlakes fell gently from a cloudy sky. Sometimes soft hail in rounded pellets and soft woolly hexagonal snow-crystals descended from an overcast sky. Oecasionally also, during summer, hexagonal iee-crystals up to half an inch across fell

* Scott, Geog. Journ. April 1905, rol. xxv, p. 366, plate.

† Drygalski, 'Grönland-Expcdition,' 1897, Bd. i, p. 80; Heim, 'Handbuch der' Gletscherkunde,' 1885, p. 202. 
from a elear sliy; on the surface of the Ross Piedmont, they supplied much of the superficial ice of the area. In the course of a day or two the erystal-plates break up into grains, which drift hither and thither with the wind. After a hlizzard, soft. snow usually hecomes tightly packed, and the snow-dunes whieh have been formed show a smooth and hard surface. Later this dune-snow granulates, notwithstinding that the temperuture remains eonstantly below $0^{\circ} \mathrm{F}$. If a wind smings mp, the grains are carricd away and the dunes disappear. Graduated pegs were set up in the snow to determine the changes which take place in its surface, and the observations show that during two years much snow drifted past them. Wiud carries the snow bodily away; the importance of this factor in reducing the height of the inland-ice of Sonth Victoria Land will be appreeiated if we recall the six and a half days during whieh the slerlge-parties were weather-

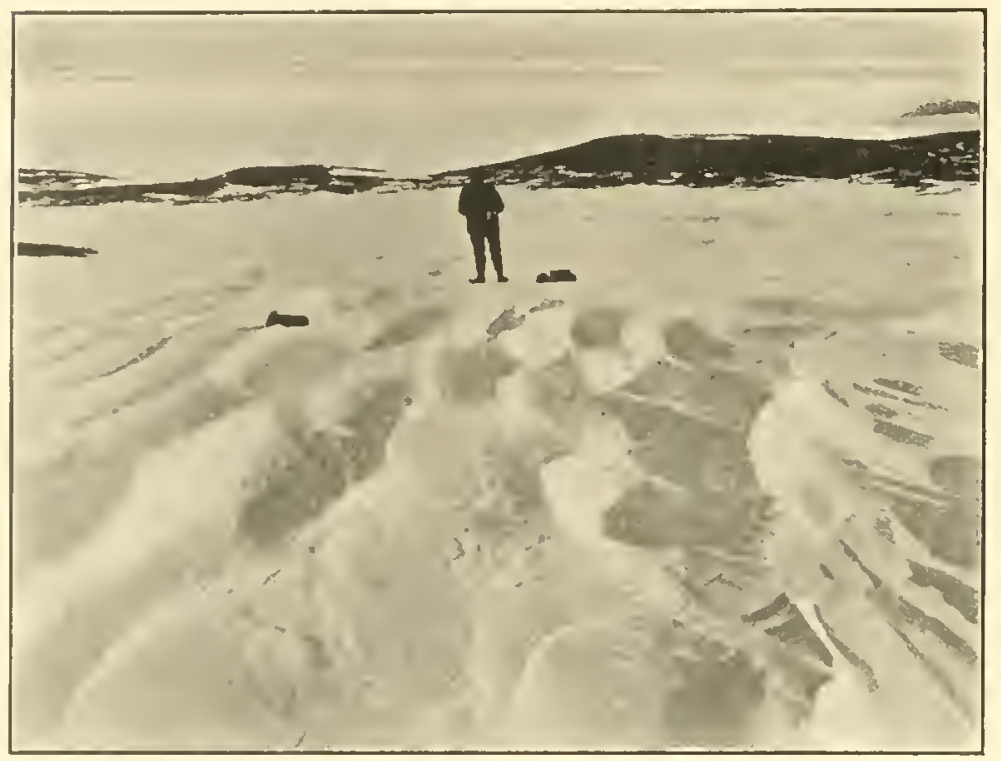

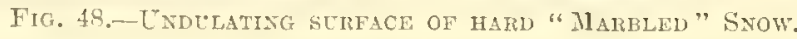
lound on the erge of the inland-ice. During that week, the air, which passer at an average rate of 50 miles an hour, was so charged with fine suow that ohjects 10 yards away were indistinguishable. That this is not unusual may be inferred from the fact that at Winter Quarters the days on which no silting, $\mathrm{Or}^{\mathrm{r}}$ surfice-drift, of the suow took plice were few.

The winds by carrying snow on to the surface of sea-ice help to drain the

land; and the sea-iee, as it hreaks up and Hoats north, takes away much superfluous water-substance which has had no opportunity of glaciating the land (Fig. 49).

The snow-dunes ustally took the form of ereseents and symmetrical elongated domes, never more than three feet high. The longer axes of the domes were parallel to the direction of the prevailing winds, those of the erescents transverse. As soon ats their substance hecomes granular, the winds remove and obliterate all trace of them.

1) ming the process of destrution, snow-surfaces resemble a wind-worn surface of filse-bedderl and slightly indurated sand. The less gramulated layers are the more inturated, and stand out heyond the coarser and less resisting bands, thus giving the apperance of stratification. The forms assmmel by the disintegrating dunes are viry varialle, * and some heeome very fantastie. The silting snow helps

* Vaughan Comish, Gicogr. Journ., Angrast 1902, vol. xx, 1) 137. 
the wind and behaves like a sand-blast, cutting away both the soft and the hard layers.

No transformation from snow to glacier-ice could be observed. Present elimatio conditions are such that thawing, even partial thawing, only takes place very lorally, and all the surfaces encountered were either granular white snow or compact ice. Even at the head of the Ferrar Glacier the change from snow to ice is absolutely sudden, and along the base of the great cascades the ice presents its characteristic rippled surface. Local accumulations of snow do oceur in the larger depressions, but the line separating granular snow from glacier-ice is always sharp. A few snow-dunes were aliso seen, consisting of opaque white snow, too hard to be cut even with an iron spade.

In 190: Lieut. Anminage travelled up Ferrar Glacier over soft snow, and at one of his camp-sites left pieces of spun yarn, a tin and a pieee of wood; they were found by our party a year later and lay loose upon hard transparent ice; the tracks of his men and sledges conld have been followed all the way up the glacier. The sledge-tracks appear as two parallel ridges, standing in relief nearly an ineh above the general ice-level. The footprints of the mes also stood in relief, but the dark objects left lying about were not so raised. From these fucts it would seem that in this locality loss by ablation exceeds gain by precipitation.

A surface of white snow absorls little ineident radiant heat. Owing

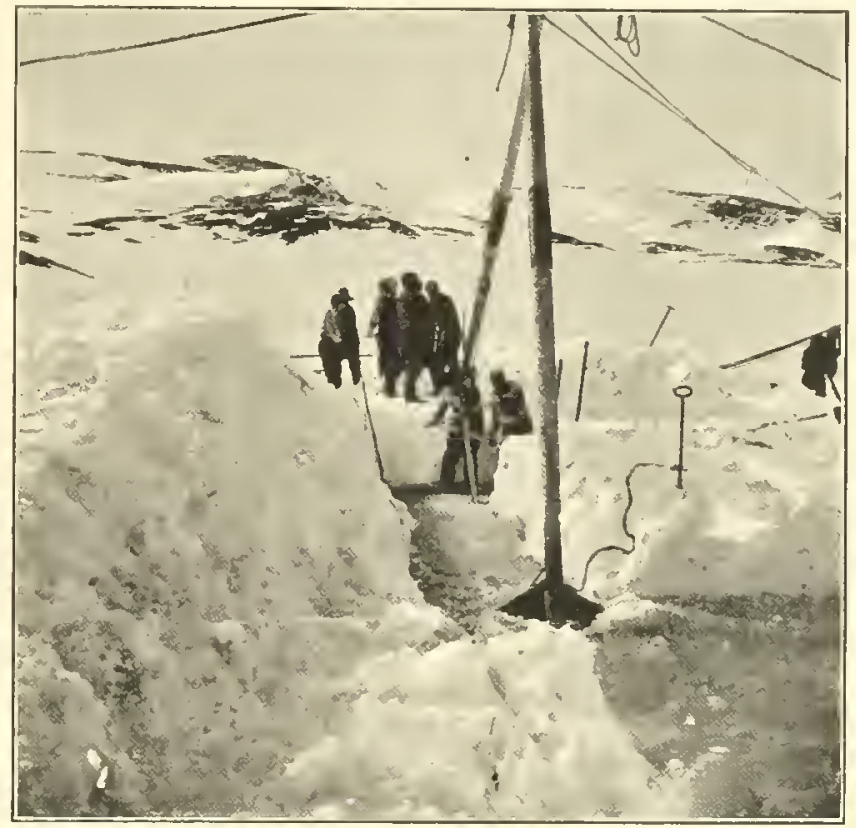

FIG. 49.-THE TWO LOWER MEN ARE STANDING UPON THE UPPER SURFACE OF SEA-ICE DEPRESSED BY SNOW BELOW WATER-LEYEL.

to the low temperature of the air, the growth of the grain can therefore only take plaee slowly. In sheltered spots or near bare rock, snow and ice melt rapidly during summer, and even in the open long furrows filled with water * appear. The best example of this was seen among the hummocks near Black Island, where long furrows filled with fresh water separate rows of hummocks (Ifiugl $\dagger$ ) from one another:

Temperatures at fixed depths in the ice were determined during 1903, and the observations show that the variations from day to day are surprisingly small. It will suffice here to note that the highest temperature reeorded at a depth of six feet was $-9^{\circ} \mathrm{C}$. and the lowest $-24^{\circ} 4^{\circ} \mathrm{C}$. The change was gradual throughout the year.

* Drygalski, 'Grönland-Expedition,' 1897, Bd. i, p. 78, plate.

† Drygalsli, 'Grönland-Expedition,' 1897, Bi. i, p. 86, plate. 
The minimum realing was taken after mid-winter and the maximum oceurred in January, and hence a considerable $\operatorname{lag}$ in temperature is produced by the six feet of ice. Temperatures at greater depths in the crevasses * show that there the lag in temperature is even greater, and also that the maximum temperature reached loy the iee is far below the melting point. The following observation from a erevasse near the junetion of the ice of South-west Arm with that from inland is of interest:-

November 3ri, 1903, 7 P.M. Depth of erevasse 30 feet.

Temperature of the air $+20^{\circ} \mathrm{F} \cdot\left(-6 \cdot 7^{\circ} \mathrm{C}.\right)$.

Temperature of the ice $-21^{\circ} \mathrm{F} .\left(-29 \cdot 4^{\circ}\right.$ (.).

* Drrgalski, 'Gronland-Expedition,' 1897, Bd. i, p. 450 ; ITeim, 'Handbuch der Gletscherkunde,' 1885, p. 288; Nansen, Meteorological Report, 1894, 1895, 1896. 
Chapteri Ni.

\section{DENUDATION.}

Wind-action.--The winds in South Victoria Land prove to be as strong and as constant as any oceanic trade-wind. Around Winter Quarters the bare land-surfares are usually eovered to a depth of six inches lyy a louse cloak of rock-déturis. Below this the eartl is permanently frozen throughout the year, and here rock-surfaces due to fracture often seem to remain quite unweathered. The layer of rock-clebris consists of a mixture of occasional boulders, abundant small stones and roekchips, embedded in a matrix of impalpable flour, and all would seem to be rapidly disintegrating. Many of the boulders seem to have no very definite outer boundary, and the protected surface may be seen to pass gradually through a state of crumbling (547) into impalpable powder (4t6). This eloak is usually damp for a week or two in summer, but becomes dry and loose when frozen during winter. Here decomposition and disintegration proeed simultaneously, and any particles loosened by frost from the upper surfaces are at once blown away by the wind; the fine material

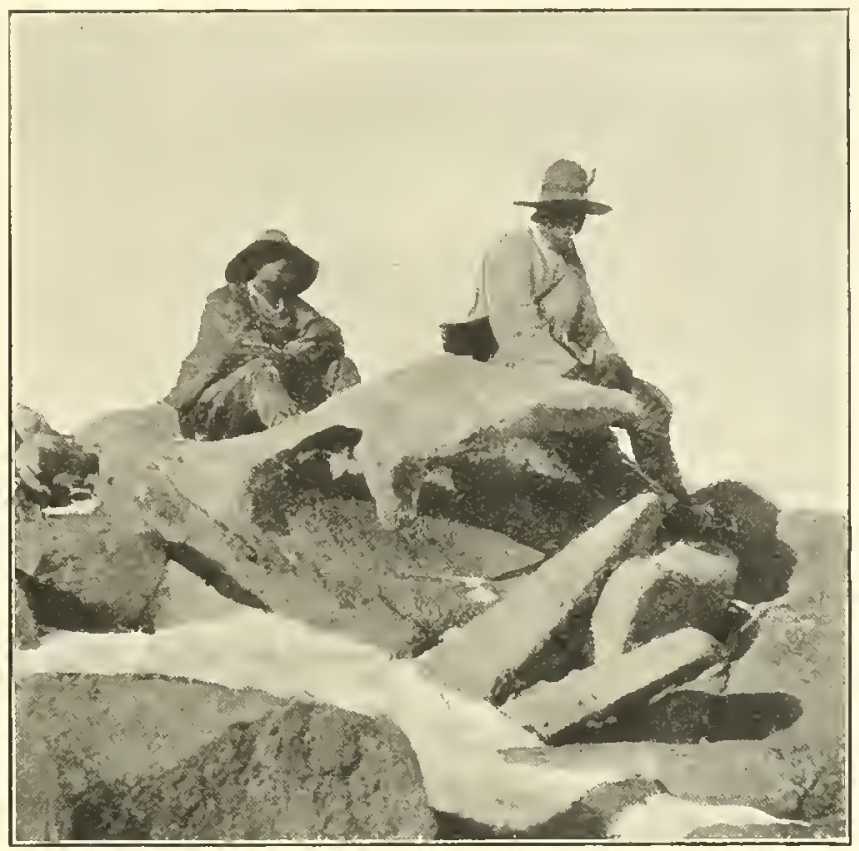

Fig. 50.-Hollowed Granite-bovlder with Incrustation of Calcium Carionate, near Descent Pass.

which remains is always an inch or so below the loose layer of stones at the top of the deposit.

The loose stones are often smoothed and pitted (325) in the mamner peculiar to the wind-worn stones of desert regions, * and some of the harder ones have a superficial glaze. Some of the boulders are too gramular to receive polish ; gradually crumbling away, they for a time leave patches of small angular fragments, still too large to be transported by the wind, to mark the spots they once occupied.

The wind has carried away the smaller rock-fragments from the summits of Observation Hill and Castle Rock. Those which remain are upwards of two inehes in diameter. The summit of the former, which is composed of trachytic lava, is

* Walther, Abhand. math.-phys, Cl. d. k. sächs, Ges. Wiss, 1891, Bd. xvi, p. 447. (Dreilsanter.) 
honeyeomled to a remarkable extent. The boss of trachyte ahove Cape Crozier, the kenyte of Cape Royds and basalts of other areas, show similar wind-effects.

The Beacon Sandstone of the Royal Soeiety Range, likewise, was almost free from the fine lisintegration-products, partieular heds being often bare for lengtls of a mile or more. The loose quartz-grains derived from these seem only to remain in crevices or below projecting rock-shelves. Dolerite-eolumns, too, are quite smootl, and are eoater with a bright ehocolate-eoloured crust (670) rarely more than one-eighth of an inch thiek.

Hollowed granite-houklers (Fig. 16, P. 34; Fig. 50) were observed at the foot of Royal Society Range near Descent Pass, and two types may le distinguished.

(A) In fairly normal granite. The roek $(555,556)$ is a grey to pink granite

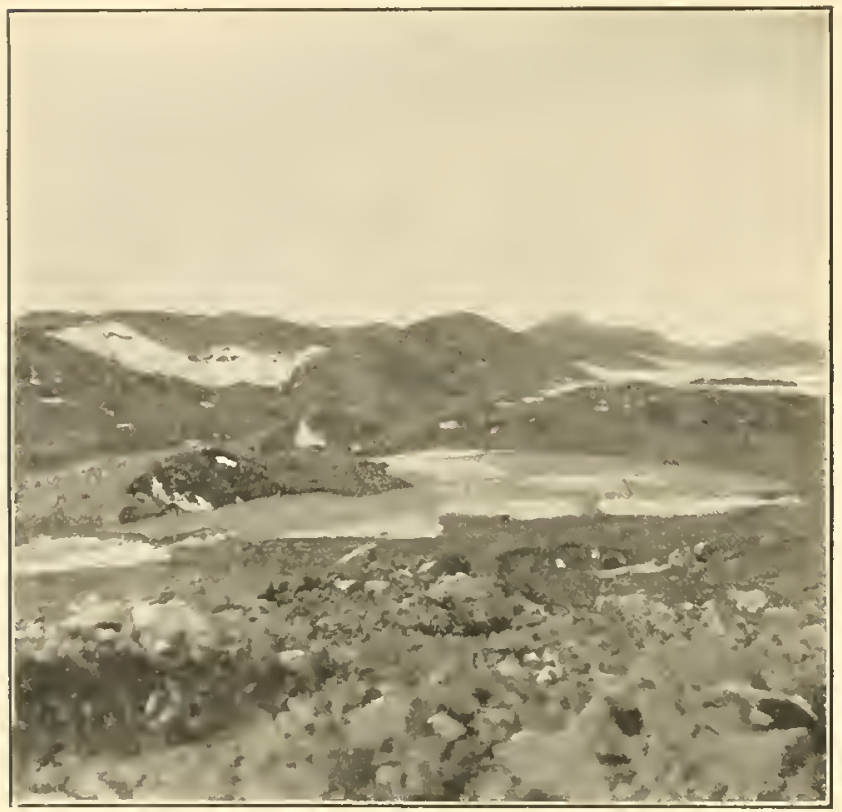

FIG, 51.- SALINE TONI IN MORAINES ON WEST SIDE OF MCMERDO SOUND, with felispars usually about a quarter of an inch long; it appears to be quite fresh even on the surfaee, and has a marked superficial glaze on loth convex and eoncave surfaces. The most striking eavity is on the south and weather-side of a large block and therefore faces away from the sun; it is about eighteen iuches accoss at the opening, and the diameter increases inwards to at least two fect. The deptli of the cavity is a little more than a foot, and the lack wall is partially eovered with a hard mamillated or lotryoidal crust (55t), consisting mainly of calcium carlonate, the surface being white, and harsh to the touch. The crust was lamellar, searecly more than one-eighth of an inch thick, lut the projecting lotryoids, which are sometimes partially hollow, may be more; it was firmly fixed to the granite-fiee, so that it was impossible to deeide whether the sunface lieneath was or was not glazerl.

(B) In a very coarse granite eontaining abundant large crystals of orthoclase. The hollowed blocks $(557,558)$ are roumled, but the surfice, owing to the rapid disintegration, is ronghened rather than glazed. The largest ravity is in a lolock 6 fert loy 4 feet by 4 feet, which is hollowed almost to a shell. The arvity is four fect long, three fect deep, and two feet high, and has four apertures varying from a frot to righteren inches in dimeter, one on each side of the block. The lip of the apertures is exceedingly sharp, the angle being rertainly not greater than $30^{\circ}$. No incrustation was seen on the walls of this cavity, lut on the floor is a 
sprinkling of the finer disintegration-products of the granite which abundantly litter the surrounding area.

These eavities in erystalline rocks apparently resemble the eavities in granite observed by Mr. F. F. Tuckent * and Professor T. G. Bonney $\dagger$ in Corsica and by the Rev. R. BARoN + in Madagasear, but the inerustation of calcium carbonate shows that wind is not the only factor involved in their formation. As in Corsica, many saucer-like depressions and a few potholes were observed, and seem to mark stages in the development of the eompleted cavitics. Interual incrustations do not seem to be recorded, but Mr. BARON mentions a "white powder alkaline to the taste" as oceuring in the hollowed blocks of Madagascar.

Water-action. - Water, as an agent of denudation in South Victoria Land, is at present a factor of limited importance (Figs. 51, 52, 53). On glaciers it merely washes away the finer material already thawed out of the ice. On bare rock it seldom appears, but along the south side of the Kukri Ilills and in other places a marked water-channel occupies the marginal ice-area, and in summer water flows along the junetion of ice with rock. Water, therefore, may undereut roekeliffs and tend to widen and terrace the sides of valleys. Any ice thawed away by water is at once replaced by the advance of fresh ice, a process which tends to render permanent the course of the water-channel. Actual undercutting of rock-cliff was only

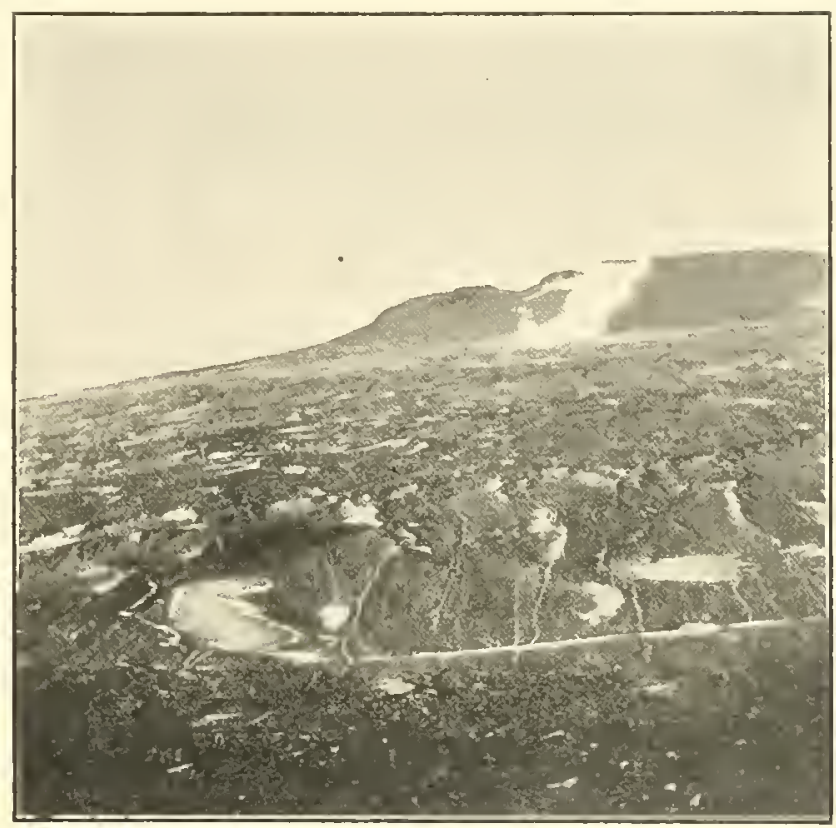

Fig. 52.--ivater beparating Mud fron Gravit in thi Moraines on Minna Blufr. seen occasionally, but at the foot of the hill D, along the Cathedral Rocks and along the foot of the granite hills $\mathrm{C}_{3}$, was most evident.

During the summer, water everywhere distributes mud and sand over the ire. Much of this mud is derived from the moraines which protect ridges of ice, and the rumning thaw-water sorts sand from gravel and fine mud from samel. In this way stratified and false-lodded sands and gravels may be derived and appeall among morainic accumulations (Fig. 52). Channels cut in the floating glacier-ice are common at the head of MeNurdo Sound, and during summer

\footnotetext{
* Tuckett, Geol. Mag., Dec. V, 1904, vol. i, p. 12.

$\dagger$ Bonney, Geol. Mag., Dee. V, 1904, vol. i, 13. 389.

$\ddagger$ Baron, Geol. Mag., Dec. V, 1905, vol. ii, p. 17.
} 
the water flowing through them often spreads sand and mud over the surface of the sea-ice.

The nost notable effects of water-action in the area were seen on the north-east

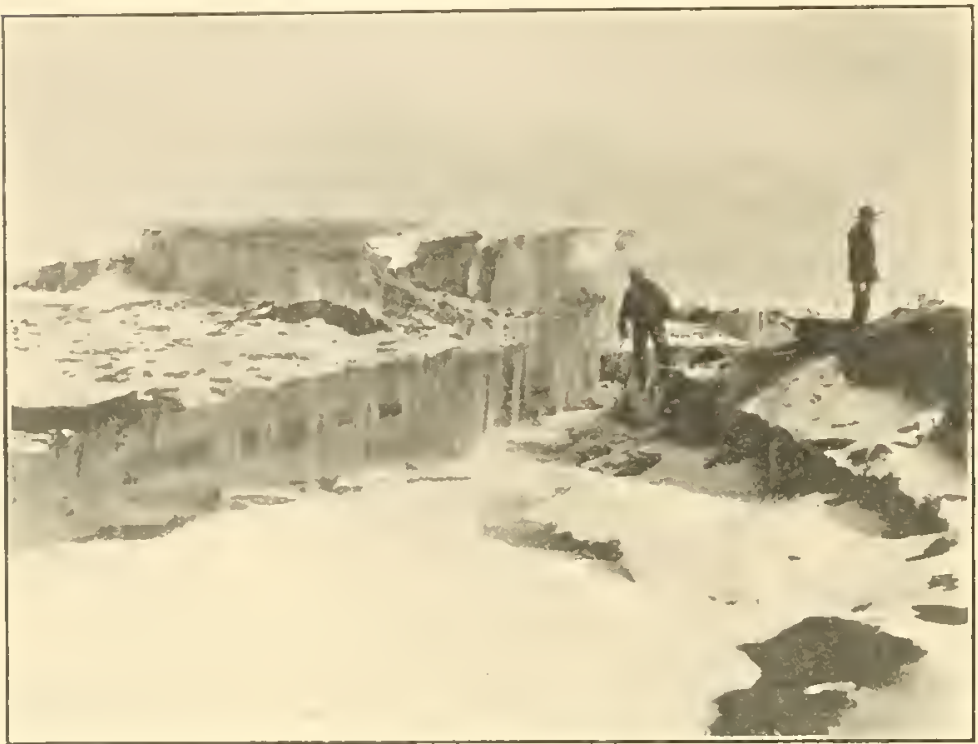

Fig. 53. Water-chandel on Floatixg Ice in MuMurdo Sound, side of Brown Islimel, an island which retains practieally no snow on its surface. In January, 1902, a very warm elear day followed a stmmer show - storm, and eaused a rapid melting of the snow just deposited. Rivulets hecoming confluent produeed comparatively large streams, which coursed in straight and narrow trenches down the hillside. The slope here is very steep, and trenches sometimes 20 feet deep had been eroded. The eontrser material washer off the hillside sprearls out as a delta on land, but much of the finer material is carried further by the muddy stream, in and out amoug the lines of moranes, and distributed over the surface of the floating glacier-ice. We olserved a stream incruse in lepth from one foot to three feet in the space of in few hours. The swollen stream euts into the 1 roterterl moraines and, overflowing the more level areas, there deposits its silt. Finally, the stream coursing northwards into Mcllurio Somml passes off the pinnacled or floating glarcior-jec on to the senine whirh its finest sediment then sullies (Figs. 5:, 5t).

I similar flood must have necurterl early in

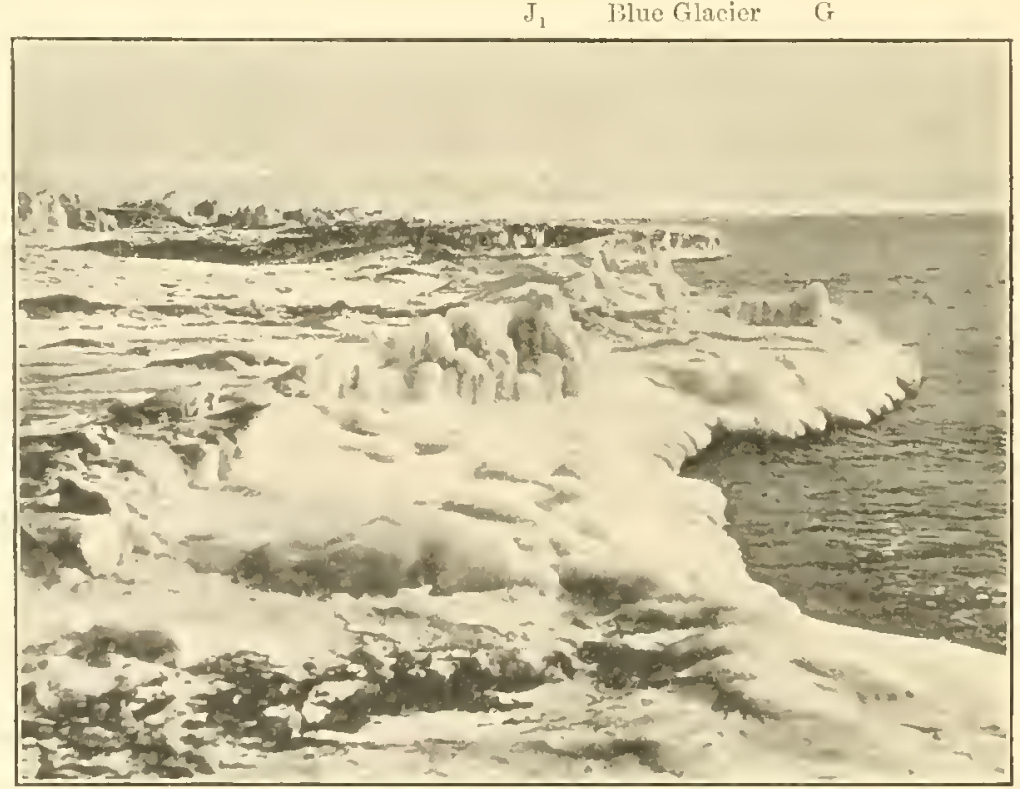

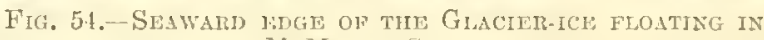
MejILndo Sound.

\footnotetext{
* Ferrur, Geog. Joum., April 1905, vol. xxv, plate, p. 374.
} 
December, 1908, for an area of sea-ice, six square miles in extent, was found with an average of eighteen inches of muddy water upon it. Some of this water may possibly have been produced in place, for this inundated area lay along the north edge of the floating glacier-iee, and during the winter-gales must receive foreign matter.

Chemical action.- Chemical decomposition of rorks is more obrious in the dry climate of South Victoria Land than in other areas, for rain can usually remove soluble salts as fast as they form. On IIut Point all rock-fragments liave thin incrustations of sodium sulphate (398). The incrustation is sometimes so abundant that the rocks look as if they have leen dusted over with lime or Hour ; if the loose surface-matter be scraper away, thin diseontinuous beds of the pure salt may be seen dipping gently into the hill. The surfaces of many houlders in The Gap are covered hy a lace-like network of white lines $(262,260)$ consisting of cal rium carbonate.

Near the nortli end of White Island a great quantity of perfect "rystals of soliun sulphate $(\approx 98)$ was obtained on a mound of the floating glacier-ire (Fig. 55). The perentage of water in this salt, as determined by Dr. Prior, was $55 \cdot 86$, which is virtually identical with that characteristic of pure Miralilite or Glauber Silt.

Near the isolated moraines in the bay between White Island and

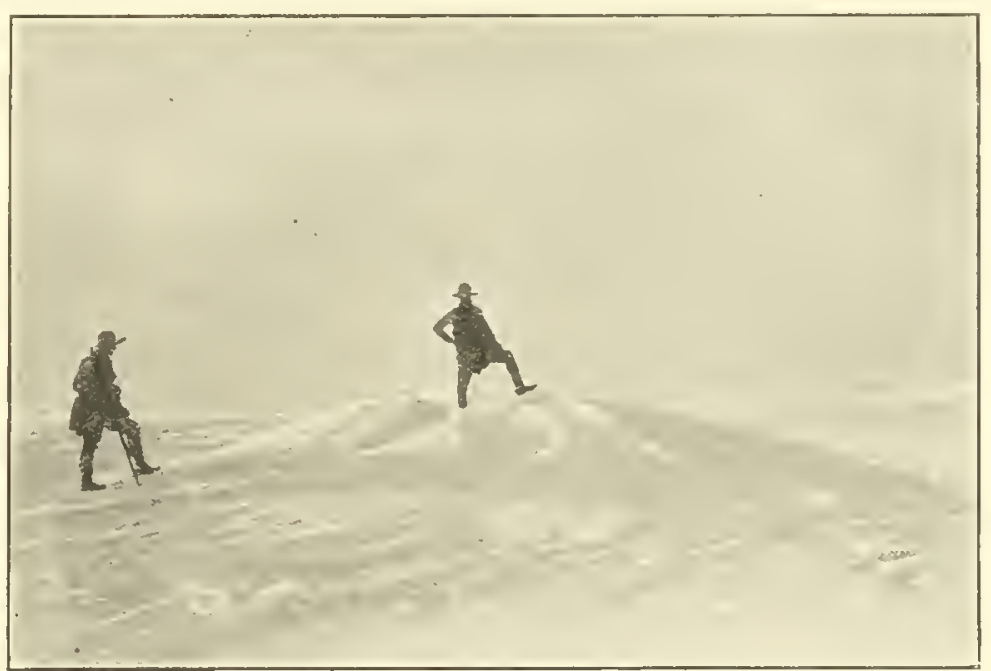

Fig. 55.-Fractured Done in the Floativg Glacier-ice, Near tite spot Where Sodum Sulphate Crtstals were found, two Miles FroM THE NORTII END OF WHITE IsLAND.

Black Island, on floating glacier-ice, there are five or six mounds, two feet high and up to five feet across, of the same white salt (623). The mounds are entirely composed of the salt, which is in well-formed crystals, though the outer ones have effloreseed to some small extent. The moraines near these mounds contain lulumus shells (612) together with ice-scratched granite and other houklers (Fig. 46, p. 80). In one of the moraine-cones on the west side of MeMIurdo Sound, a bed of this salt (741), about eighteen inches thiek, is traceable horizontally for alout ten yards. This bed is at least 50 feet alove a pond of brackish water which occurs at the foot of the moraine. Dr. E. A. MiLsox also found this salt $(740)$ near the head of Discovery Gulf, and Mr. T. T. Honcsos ( $74: 2$ ) on Inacessible Islaud. As many of the pouds among the moraines are much too saline for drinking, it is possible that this peculiar and abundant concentration of solnble salt may be due to a former crystallization from similar ponds. 
Frost-action.-Owing to the very low temperatures prevalent in high southern latitudes, the denuding action of frost is not strikingly conspieuous. As a rule, the wind removes all snow from bare rocks, and a marked line always diviles the lowal snow-fields from the areas free from snow. Thawing and freezing only orcur near the edge of snow-fields, and, therefore, owing to the general absence of water, frostaction is one more rendered impotent. Castle Rork was perhaps the hest example of a frost-riven mass near Winter Quarters. It rises sheer above the snow-covered peninsula; but the side facing the sum (the north side) slopes steeply down to shore-ice nearly 1000 feet below. Snow is drifted by the prevailing easterly wind on to the north side, and in summer large riven blocks fall down and litter the area below. The north side of Catlechral Rocks is similarly shattered; from its pinnacled outline it would appear to be more subject to frost-action than the isolated pealis further to the west.

The dolerite, though forming no prominent talus-slopes, appears more prone to split than other less-jointed rocks and a conspicuous ledge is always left at its contact-junctions. Where dolerite oceurs above sandstone, a terrace of the sandstone stands out in front of the steep dolerite-cliff. Fans of dolerite-talus are very conspicuons in the smaller of the Dry Valleys, also below the hill D, and along the soutl side of the Kukri Hills.

No serees encroach upon the upper parts of the Ferrar Glacier, and the dolerite usually rises perpendicularly from the ice. Along the iee-streams talus-fans are rarely abundant enough to become continuous even at their base. The sandstone undergoes little frost-action. Often its surfaees still retain the rounded outlines which have been produced by ice-action. All transport of rock-material is now accomplished by wind, which carries off the sand-grains as fast as they are loosener.

An important agent in wearing down the sandstone, and one which can hardly be classed with any of the ordinary agents of denudation, may be included here. The columns of dolerite, in falling down the eliffs, break away the softer santstonebeds and produce a sort of "chimney talus-shoot," which conveys the détris to the fan at the bottom. (Other fragments follow this line of descent, and thus the deepening of the gully is aecelerated. On the hill $x$ several such gullies may he seen. At a height of alsont 500 feet above the iee, the edges of the sandistone-berks which have been caught up by the dolerite (see p. 46) are serrate, and at one spot a groove or gully, 20 feet wide, of $\mathrm{U}$-shaped section, has been produced. This groove has perpendicular sides, and the uppermost bed of sandstone has been at back 20 feet from the erlge of the clift.

The granites of Antarctica, as of other regions, seem frone to form serees. In the netamorphic limestone area, the hills are usually so rounded that there is selem an opportunity for a loosened block to change its position, and no transport takes place until the rock is so finely disintegrated that it can be carried off' by the wint. 
Ice-action.-Adopting the same plan as before, we shall bricfly review the general action, as a geological agent, of each specificd form of ice. The sea-ice, as already pointed out, seldom runs aground, and is therefore negligible as an agent for striating or abraling rocks or for contorting beach-deposits. Sea-iee forcel up on to the land las been observed at only one spot. This was the rery exposed north-east rorner of the strunded moraines on the west sirle of MeNurdo Sound, where sorting and rearrangement of the moraines is so constantly happening that no permanent effects of sea-ice could be traced. As a transporting agent, sea-ice is not rery effective. Sometimes a boulder may roll across the fringe of shore-iee on to it and he taken out to sea. The original boulder may be angular or it nlaty be ice-scratreder ; its condition when on the ocean-floor can hardly he said to indicate its method of transport. Dust and fine sand are often blown on to sea-ire and may then lre further transported. In Wood Bay great numbers of pumice-pebbles (899) had been blown on to sea-ice, which would be drifted far to the North by the prevalent ocean-currents before it melted.

The shore-ice has a conservative * effect upon the land. It binds together the talus of the hills, and so protects talus and rock from the eroding action of drifting ice-floes or waves. When a piece of an ice-foot floats out to sea it usually

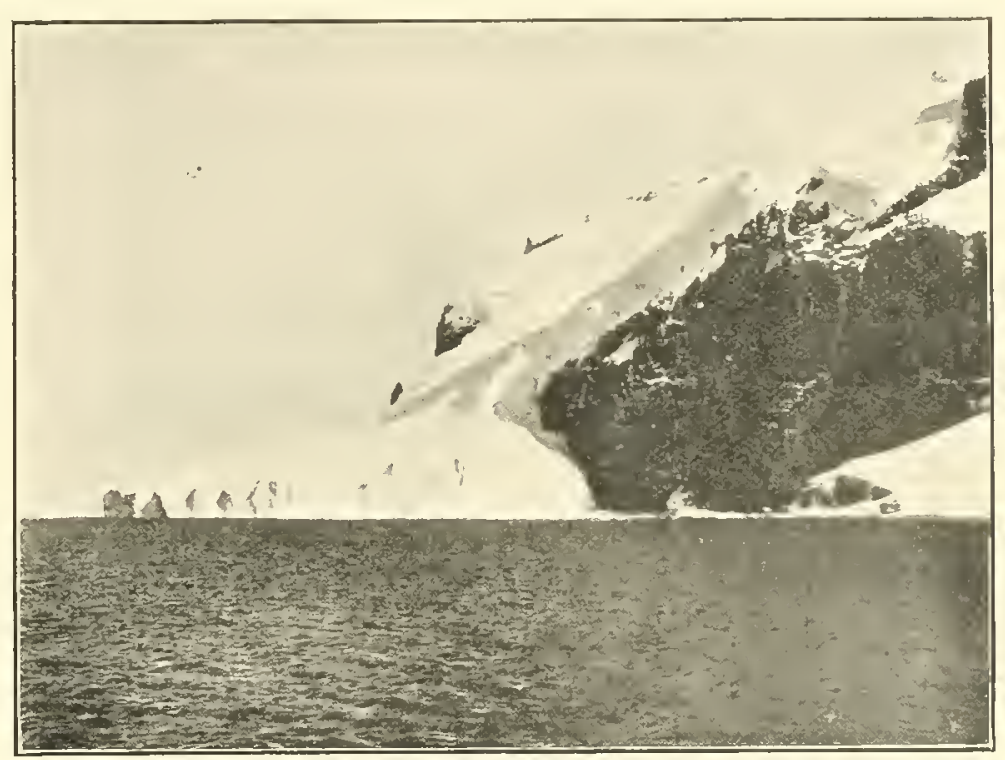

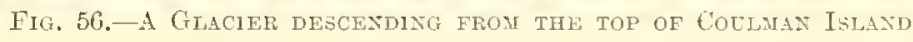
INTO THE SFA.

carries a great load of débris. Stones roll on to the surface, and, through the melting of the ice around, work dommwards. Pockets of dust (Krymlionit) $\uparrow$ are excedingly numerous; probably also much rock-material is held within the sole. All these must be transported. As ice which has left the shores of Sonth Victoria Land seldom grounds, the abrading or striating action of shore-ice there must be small.

The glaciers taken as a whole are not now modifying the form of the land to any great extent. The corric-glaciers and ice-slabs appear to be aggraling rather than excavating the valleys in which they lie (Fig. 56). The corrie-glaciers at the Inland Forts have a Bergselurend, but, judging from the small amount of terminal

* Bonney, Quart. Journ, Geol. Soc., 1902, vol. lviii, p. 699; Bonney, Geog. Journ., 1893, vol. i, pp. 481-499.

† Drygalski, 'Grönland-Expedition,' 1897, Bd, i, p. 94, ff. 
moraine cucircling them, no serious "plucking" of large rock-masses" can now le taking place. This plucking loes seem to be illustrated in the ice-free cirque to the morth of the Forts. There several blocks of Bearon Sandstone, as much ats 20 feet in diameter, have been extracted and transported about 50 yards; the sorkets from which the boulders are derived are still very evident, and contain frozen water-ponds.

The ice is eresywhere retreating; some few valleys are now quite lare and are mornine-coverut. No obvious ploughing effects of ice were seen, and roches moutonnés are not hy any means conspicuous. In (iranite Harbour a few perdied blocks and a few ice-planed rock-surfaces were olserved. This harlour is fiord-like, and has depths of over 100 fathoms within a quarter of a mile of the shore. At $\mathrm{G}_{1}$ of the Northeru Foothills, close to the Blue Ghacier, the metamorphie limestones are beatutifully rounded more than 1000 feet ahove the present ice-level and perched blocks are everywhere abundant. Observations at the snouts of several glacier's seem to show that no regnlar shedding of bergs is going on. Beros from the Blue Glacier would contain a great quantity of rock-matter, and in former times must liave transported an cnormous quantity of débis.

(of the many icebergs met with, few showed rock-deloris on their surfaces, and, as piedmonts supply the vast majority of bergs, this frectom from rockmaterial is not surprising. A few bergs showed angular rock-fragments on their upper surfaces, and one or two had coloured dirt-lands interstratified with the snow-layers. Teebergs aground often capsize and bring up material from the local seu-floor; this may be further transported, for through the melting of the loerg its dranght diminishes. It the same time the rock-flour, which is a very wirle-spread deposit in the Ross Sea, is likely to be contorted by the moving herg. On the whole, then, we may eonclute that owing to the form of the coast of Sonth Victoria Laud, rock-surfaces abraded or scratched by floating ice must there be exceptional.

It woukl also seem probalile that as the sea-ice diminishes during the summer, so are the Houting piedmonts now diminishing. The numerous soundings talsen by the '] Hiscovery' along the edge of the Ross P'iedmont, at places which at the time of the royige of linss (1841) were heneath the iec, show that the sea-floor is covered with a stiff yellow clay (soundings 10-41), which contain tests of foraminifera, many diatomfrustules and a few sponge-spicules. $A$ somewhat sinilar clay (somdings 176,177 , 178) was foumd $10^{\circ}$ further north near Talleny Island, also from 368 fathoms. (sounding 13) ofl' the Nordenskiohd P'ierlmont. In water shallower than 100 fathoms oceunic curests apparently remove the fine material and, as in other regions, deposit it leyoud the littoral zone. The whole of the floor of the Ross Sea seems to consist of rock-flom milled ly the great glaciers of South Vietoria land.

\footnotetext{
* Willard D. Johnson, Journal of Geology", 1901, rol, xii, p. 573.
} 


\section{APPENIIA TO THE REPORT ON TIIE FIELD-GEOLOGY.}

\section{NOTES RELATIVE TO MACQUARIE AND AUGKLAND ISLANDS, OUTSITE TIE ANTARCTIC CIRCLE.}

\section{Macouarie Island) (Fig. 57).}

Macquaris Island is situated in the Sonth Indian Ocean in latitude $54^{\circ} 80^{\prime} \mathrm{S}$., longitude $158^{\circ} 30^{\prime} \mathrm{l}$., and it has heen suggested that it is part of the "zone of

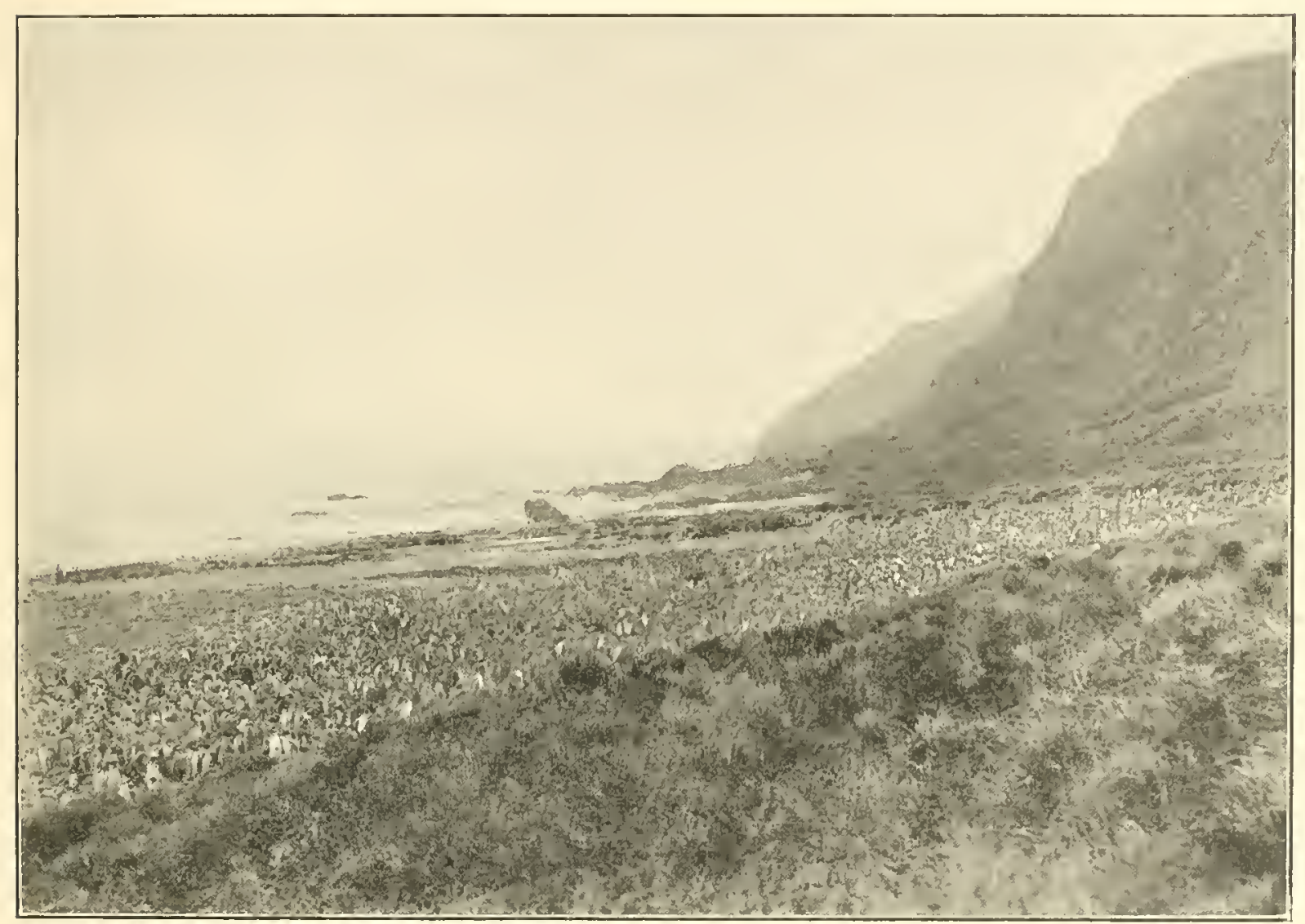

Fig, 57.--The Strand and the Steep Coast-line of the east side of Micquarie Istand.

fire" which connects New Kealand with Mount brebns and Monnt Terror. It is about 23 miles long and five miles broad. It has an averuge height of 500 feet, but one of its peaks rises to quite 2000 feet. The longer axis is in a north-east and south-west direction and the sonth-east side is a precipitous diff almost 200 feet high. The foreshore is narow and the clifis are remarkahly straight; they

* Judd, 'Volcanoes,' Bril edit., 1885, p. 230 ; Scrope, 'Volcanos,' 2nd edit., 1862, 1. 471 ; Bonney, 'Volcanoes,' 1899 ; map of distribution of Volcanoes at end of the volune. 
extend for ahout 10 miles on either side of Lusitania Anchorage, where the 'Discovery' remained for about four hours.

The cliffs do not rise directly from the foreshore but from a slightly raised platform or strand ahout 100 yards wide, and, in many places, more or less covered with talus. In places the cliff is broken by steep gully-like water-courses coming down from the plateau behind. The exposures in these gullies show that the rocks all dip at about $10^{\circ}$ to the north-west.

Small peat-hogs oceur behind the harder rock-outerops which hold back the streams; in the bogs round pebbles and sandy gravel oecur. On the seaward side of the hard outcrops a terrace at the level of the peat-hogs behind, at least 20 feet ahove the level of the stream, extends some way towards the sea. The terrace, sometimes 100 yards or more in hreadth, consists of stratified clays, sands and gravels. In plan it has the form of a delta which has been eut into by the present stream and it may possihly be a raised heach. The rock-specimens obtained are dolerites and basalts (see p. 109) which show little relationship to those from South Victriria Land.

All the specimens are voleanie, many of them are slickensided, and others, such as (9), have olvionsly heen considerably crushed. The specimens (1) to (6) inclusive were rollected sucessively on on way up the gully. The specimen (11) came from a height of about 1000 feet, from a hold crag overlooking the peathogs.

I few dykes are seen crossing the strand. One of these (13) is 20 feet across, and, with another (12), runs out to sea as a dangerous reef.

\section{A tokland Islanids (Fig. 58).}

This grom of islands was visited by Sir James Clakke Ross, and the specimens collecterl have been described by Dr. Prior. *

T'he hills surrounding Ross Harbour rise over 1200 feet; they appear to be built up of series of hasaltic sheets, $\uparrow$ hut owing to the extreme density of the regetation few exposures could be found. These occur as "scars" or small clifts, over which streams sometimes plunge as waterfalls, but the scars are seldom high conough to rise above the brushwool. The lowest rocks exposed along the shore are all hasalts, and are mush more porphyritie than those (879 and 880 ) from the smmmit of $\mathbf{H}$ omut Eden. All the lasalts at sea-level are prominently eolumuar; the columns are about two feet in diameter and are sometimes, e.g. Deas Head, 300 feet high.

The eastern coast of the main island is a maze of fiords into which flow the streams coming down from the western peaks. All the ligher peaks lie

* Prior, Mineralogical Magazine, 1899, rol. xii, p. 71.

$\dagger$ IIector, Trans. New Zealand Inst., 1870 (1869), rol. ii, pp. 179-183. 
close to the western shore, where the land rises sheer from the sea as an enormous cliff. This elift would seem to be undergoing rapid denulation by reason of the prevailing westerly winds. The basalt-sheets dip slightly to the eastward, and at sea-level occasional dykes $(877,892,893)$ may be seen.

Another point of interest is the delta at the head of Laurie IIarbour, the inner land-locked part of lioss Thabour. This consists mainly of sand and shingle, but has occasional shell-layers which in some cases are several feet above the high-tide mark. The main stream of the Laurie Harhour valley now cuts into this and it would therefore appear, that here, as in Macquarie Island, we have some evidence of very recent elevation. Again, near Erebus Cove, a low spit of rock is corered by about 3 feet of clay (874) and houlders. All the boulders are rounder and

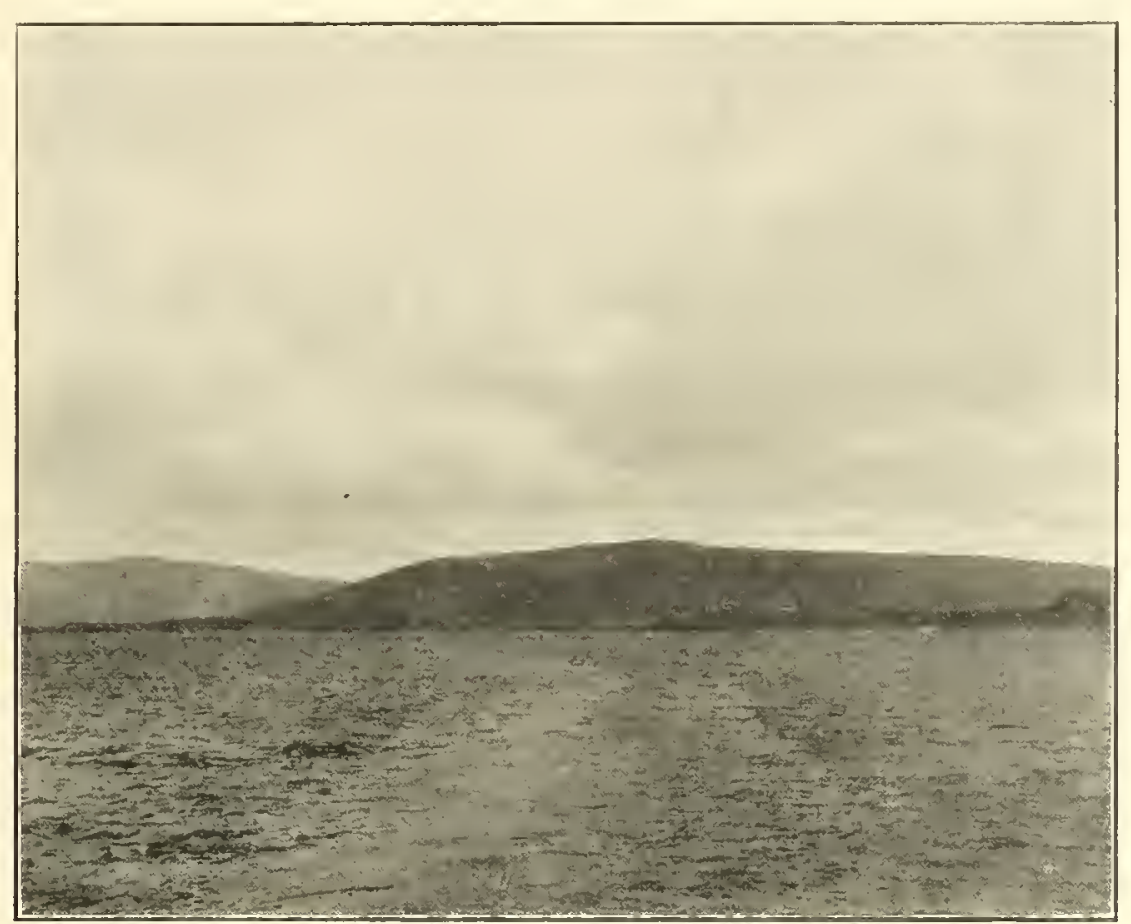

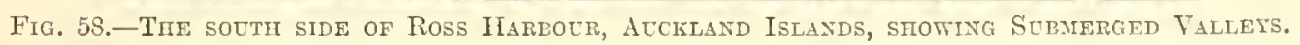

water-worn; they vary from two inches to a foot in diameter. The smaller boulders oecur in layers as if stratified, and the whole is overlain by a bed of peat. Basalt-outpourings were found in Enderby Island, and in addition curious deposits of elay and sand also oecur. The elay seems to eap the basalts of the interior and is easily distinguished by its covering of tussork-grass. The sand appears in Sandy Bay as a hare hill edged with trees. 


\section{SUMMARY.}

AlTHousn the geological work of the 'Diseovery' Expedition was confined to a linited area, the eollections of rocks and photographs which have been obtaned provide matcrials for forming some definte conchnsions as to the geologieal history of the regrion. The other experlitions, which lately entered the South Polar Regions, worked in locilities much more than 1000 miles distant from the 'Thiscovery' area and from each other, and information obtained in one alrea may not hold for all.

Chapter I deals with most of the islinds which ocrur at intervals along the

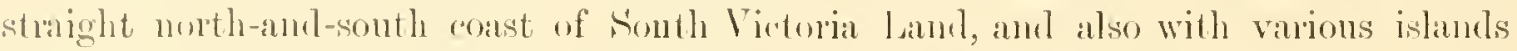

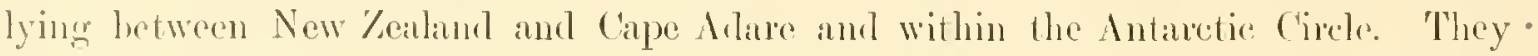
alre bommled hy inaressible alfis, and the stirromeling sea is rompantively shatlow. Apparently they all eonsist of reeent voleanic rocks.

Chappler II deals with the islands in the vicinity of Mount Erebus and our Winter Guarters. This group I lave spoken of as the lioss Arehipelago, and of the gratest of the group as Ross Island. This island has heen huilt up lyy the rolcanoes linelus and 'Terror, of which the former is still ancive; only stean, never any lava ol solid matter, was seen to be enitied from the vent at its smmmit, 12,000 feret alove the sea.

In ('hapter lll the relations of the conical volcanoess on the mainland are comsirlerert. The conieal voleanoes lie at the foot of a great wall-like lange of momntains, which in latimule $78^{\circ} \mathrm{S}$. (the Loyal Society hange) has a simple tabula structure. This range is at least 800 miles long. trends due north-and-routh, and ocrasionally lises to pealis $1: 3,000$ feet high. On the east it ends ahruptly in the open lions Shat, and on the west, for a distance of 200 miles at least, it forms a grent platuan some 7000 feet alove sea-level.

In ('hapters IV, V, VI and VII, the rocks whieh huikl up this great range ane eonsidereal in the order in which they ocenr in the field.

The gneisses have been found at sea-level and at the hase of a series of rocks quite 12,000 feet thick, and may safely be regarded as forming the ancient platform on which the contral part of South Victoria lant is built.

'The granites beleng to two periods, one ohler and one younger than a certain sheet of dolerite. The older granite lies upon the gneissie rocks at the foot of the Cathedral liorks, and dykes from the former lanify into the latter. A pernliarity of this mass of granite is that it has a nearly horizontal upper surfare which can Je traed for many miles along the sides of the Ferrar Glacier.

The beacon simelstone Formation is a leposit about 2000 feet thick and remakahly miform in texture. It proved to be quite barren of organie remains 
except near the top, where, at a height of nearly 7000 feet above sea-level, fussil plant-remains were found. Unfortmately, owing to deeny of the plants and to changes produced by a neighhouring sheet of dolerite, their eharacters are ahnost inteterminate. This intrusive dolerite, though it gives no evidence of surfince-flows, forms the highest peaks of the Royal Society Range. 'The plateau-features are still obvious, but the original plateanx seem to have been dissected prior to the earthmorements which disloeated the sandstone.

Chapters VIH, IX and $\mathrm{X}$, deseribe the ice as met with in the Ross Siea area. The thickness, salinity and behaviour of the sea-ice, the shore-iee (ice-foot), and the glaciers are deseribed. The inland-iee, local ice-caps and piedmont-glaciers are "ontristed with those that have been observed in the Aretic regions. Temperatures in the ice at rarious fixed depths were determined; they show that at these depths the iee remains permanently some degrees below its melting point. lce-slabs, or gliciers whieh have slipped away at their heads owing to decrease in the supply of water-sulstanee, oecur among the foothills of the Royal Society liange, and appeal to be of a type not yet observed elsewhere.

There is one fact on which most of the observers, in both the Aretic and Antarctir: regions, seem to agree, viz, the recession of the ice. TrsosuL foretolit that the ice would he tending towards a minimum when the condensation on both poles was about equal; whereas J. D. WhrTxex $\dagger$ maintains that only general glaciation ean oeeur when there are bi-polar ice-eaps, and that we are now entering upon a glacial epoch. The ice in the 'Discovery' area was found to be developed on a comparatively small seale, the steep-sided valleys providing ahnost ideal rockexposures.

In Chapter XI the agents of denudation are disenssed. The wind plays a eomparatively important part in this dry area, while the effects of water-atetion are eonspicuous hy their absence. Chemieal action is very pronounced in some localities, while frost-action, owing to the small amount of precipitation, is almost quite alsent. The geological action of the ice is only briefly touched on.

In an Appendix are given some brief notes relative to Macquarie and Auckland Islands, at which brief stays were made during the voyage.

It is my pleasant duty to express my thanks to the many kind friends who have assisted me in my work. To Captain R. F. ScotT, R.N., C.V.O., 1).Sc., ant the ofticers of the 'Discovery,' my thanks are due for the interest taken in my work

* Tyndall, 'Heat: a Mocie of Motion,' 1898, 11th edit., p. 231, and 'The Forms of Watcr,' 1892, 11 th edit., p. 154.

† Whitney, 'The Climatie Changes of later Geologieal Times,' Mem. Mus. Harvard Coll., 1882, vol. vii, p. 321. 
and the ever ready help they accorded me; all assisted me in collerting, and the photographs taken hy Engineer-Lieutenant R. W. Skeltos, R.N., are invaluable; the arrangements made for me by Captain Scotr were all that I could have wished.

I an indebted to Dr. G. T. Prior for the names of the rocks and minerals mentioned in the text.

Lastly, I am very grateful to Mr. W. G. Fearsides, M.A., F.G.S., Fellow of Sidney Sussex College, for kindly reading the whole of the manuscript and suggesting many improvements in the text. 


\title{
REPORT ON THE ROCK-SPECTMENS
}

(OLLECTED) DLRING TIL

\section{'DISCOVERY' ANTARCTIC EXPEDITION, 1901-4.}

\author{
Br G. T. Prior, M.ג., D.Se., F.G.S., \\ Assistent in the Mineral Depurtment, British Museum.
}

INTRODUETOR.

THE rock-specimens lrought back from the Antarctie regions by the 'Discovery' Expedition are listed under about 1,000 numbers. Amongst them is much transported material obtained from moraines, seree-slopes and soundings, but most of the speeimens were eollected in situ hy Mr. Ferrar, the geologist to the Expedition.

The specimens obtained from Cape Adare, Coulman Islind, and Franklin Island consist of hornblende-basalts and limburgites, similar to those whiel were bronght back by the 'Southern Cross' Expedition and were described in the Report relating thereto.*

The following notes, therefore, refer mainly to the specimens from the Ross Archipelago, and from the opposite mainland which was the seene of most of $\mathrm{Mr}$. Ferrar's work in the fieh.

For purposes of deseription they will be taken in the following order, which eorresponds fairly closely with that adopted by Mr. Ferrar for the Report on the Fieldgeology :-

Chapter I.-Volcanie rocks.

These inclurle the eruptive rocks of the Ross Arehipelago, Scott Islands, Auckland Islands, and Macquarie Island.

Chapter Il.-The erystalline-limestones, gneisses and granites, which form the bascment-rocks of South Victoria Land.

Chapter 111.-The lamprophyrie and other dyke-rocks, intrusive in the basementroeks.

Chapter IV.-The Beacon sandstone and other sedimentary rocks.

Chapter V.-The dolerites intrusive in the Beaeon sandstone.

* Prior, Rep. 'Southern Cross' Collections (British IIuseum), 1902, pp. 321-332. 
Chapter I.

\section{TOLCANIC ROCKS.}

PASALT appears to be the prevailing lava which has heen erupted by the voleanoes of this Antaretic region. The 'Sonthern Cross' collection showed that Cape Adare and, in all probability, also the islands off the north coast of South Victoria Land, are mainly conposed of this rock; but the presence, in that eolleetion, of one or two specimens of a phonolitic character was sufficient to suggest that in this Antaretie region there is a similar association of basalts with more-acid. rocks rich in alkalies to that which prevails in East Ifrica and along the Atlantic voleanic chain generally.*

This suggestion is amply confirmed by the specimens brought back by the " Tiscovery' from the Ross Archipelago. Basalts of a basic type are the prevailing lavis, hut accompanying them are phonolitic trachytes and kenytes (trachydolerites of Rosenbusch) rery rich in alkalies. To this latter type belong perhaps the most remarkillle specimens in the collection, viz., the rocks from the slopes of Mount lirebus, showing conspirnous lenticular crystals of anorthoclase and exhibiting characters ahmost precisely identival with those of the rhomb-porphyries of Norway and the more recent kenytes of Mounts Kenya and Kilimandjaro in East Afriea.

\section{Basalts of the Ross arehipelago.}

The basalts of the Ross Arehipelago are very similar to those of Cape Adare. They present the same two types, vi\%, hornblende-basalts with few and small phenocrysts, and olivine-basalts with plentiful and fairly large porphyritic crystals of olivine and angite. $\dot{\dagger}$

\section{IIoruldende-lasults.}

T'he homblende-lalsalts are dark gray, slightly vesicular rocks, showing only sparingly small black porphyritie crystals of hornblende and augite. They are rather nore coarse-grained than the rery compact roeks of Cape Adare.

Under the mieroseope small phenoerysts of pale purplish-hrown augite and deep reddish-brown basaltic hornblende (or more often magnetite-pseudomorphs after hornblende) are seen in a ground-mass of felspar-laths, magnetite-grains, purplish augite in grains and needles, and small olivines.

The felspar-laths are mostly of labradorite, giving symmetrical extinetions in twin lamella of alout $22^{\circ}$. Apatite is plentiful in the ground-mass and as inclusions in the lomblende-psendomorphs (see Fig. 59); it has often a pinkish tinge and is cloudy with blark inclusions arranged in lines parallel to the sides of hexagonal sections.

In most of these hasalts the hornlblende is only represented hy pseudomorphs, but

* Prior, Rep. 'Southem Cross' Collections (Jritish Mnscum), 1902, p. 328, and Mineralogical Magazine, 1903 , wol. xiii, p. 261.

† I'rior, liej). 'Southern Cross' Collections (British Musemn), 1902, p. 326. 
in a specimen (218) from the top of the 1300-ft. knoll of Mount Terror it is for the most part unaltered. Most of the phenocrysts in this rock, however, show two stages of growth, in whieh variations of ehemical composition are indicated by differences of optical characters; a rounded and corroded nuclens of eossyrite-like hornhlende, having pleochroism from brown (for vibrations across the length) to black (for vilurations along the length) is surrounded by the more usual barkevikite-like hormblende with less absorption, from bright yellow to deep reddish-hrown. The augites in this rock also show similar variations in composition, and lave generally a pale-green nucleus surromded by a pale-purple zone; but in this ease the change has been continuous, and there is no evidence of corrosion of the first-formed green nurleus.

The hornblende-pseudomorphs in these rocks are similar to those which have been often described. $\dagger$ They consist mainly of grains and rods of magnetite, sometimes in radiating groups, but generally arranged in lines roughly parallel to the length of the erystal, with pmplish angite and a little felspar crystallised about them. With the magnetite is usually associated a cossyrite-like homblende, showing pleachroism from deep brownish-red for vibrations across the length of fibres to nearly oparue for viluations along the length. The pseudomorphs are generally surrounded by a narrow, sharply definer border of purplish augite like that of the ground-mass.

According to Becke's theory $\$$ the alteration and

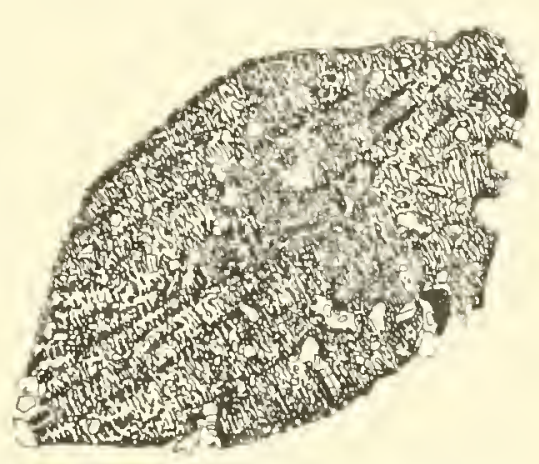

Fig. 59.-Pseudomorpir after HornBLENDE IN BASALT (601) FROM Castle Rock, Showing inclusions of APATlTE. (Magnification, 10 diam.) partial absorption of the horublende probally trok place during phases in the eruption in which the pressure diminished much more rapilly than the temperature.

A quantitative chemical analysis of a hormblende-basalt from the Sulphur Cones (385) gave the following result \$:-

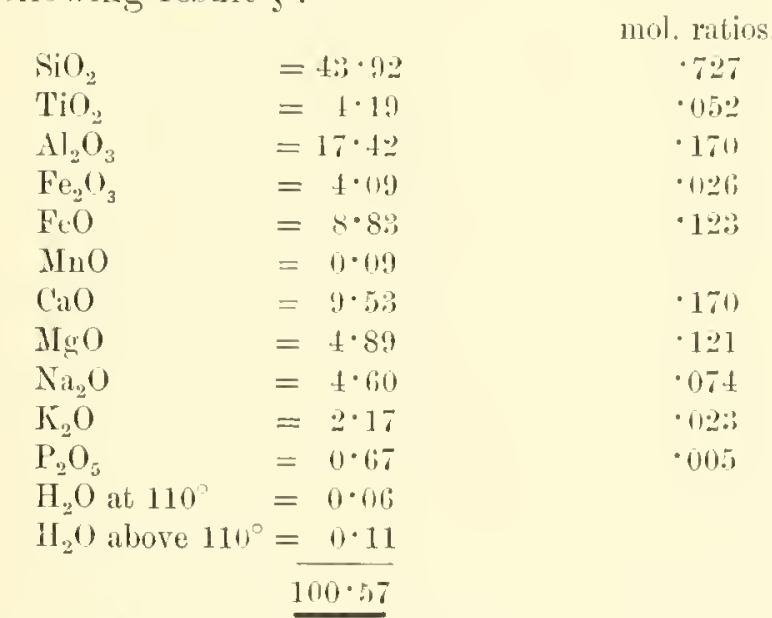

* The numbers refer to Mr. Ferrar's List of Specimens.

† For bibliography see Hyland, Tschermak's Min. Petr. Mitth., 1889, Bd. x, p. 238; also Washington, The Voleanoes of the Kula Basin in Lydia, New York, 1894.

$\ddagger$ Becke, Tschermak's Min. Petr. Mitth., 1596-7, Bd. xvi, p. 335.

$\$$ For discussion of the results of analyses see p. 119. 
IIomblende-basalts were found on the 1300-ft. knoll on Momt Terror (218), at the Sulphur Cones near Winter Quarters $(382,385,391)$, and also on Brown Island (608). The latter specimen is almost precisely identical in micoseopie characters with the rorkis from the Sulphur ('ones.

\section{Olivine-lussalts.}

To the basalts with porphyritic erystals of augite and olivine belong, apparently, most of the more basie lavas of the Ross Arehipelago. They are dark-gray to black rocks, showing to the nakeal eye numerous crystals of these minerals. By increase of glass and decrease of felspar in the base they pass intu limburgite-like rocks, in some of which the elear yellowish-green olivine-phenocrysts reach a considerahle size (up to 1 in. in length).

Inder the microseope (Plate VIII, Fig. 1) the olivines are seen to he mostly of very irregular ontline and to be often deeply indented and comoded: they are clear, colonrless and fresh, showing generally only a few inclusions of magnetite. A marked exception to this rule, however, is presented hy the phenocrysts of a basalt from Inthom Ifeights (366), which resemble closely the psendomorphs after hornblende described above (Fig. 59), since they are rendered almost opaque with magnetite arranged in parallel lines. They may possibly mak a stage in the conversion of hornblente into olivine.* In some of the more limburgite-like rocks (e.\%., 176 from (ape ('rozier) the olivine shows small brown oetahedral inclusions of picotite, and also numerous vermiform inchisions similar to those in the augite and olivine of the nodules deseribed in the following section (sec Fig. 60, p. 108).

The augite-phenocrysts are of the pale pmplish-brown tituniferous variety common to basaltic rocks. As in the hornblende-basalts, variations of composition are indicated by changes in tint and hy zonal structure exhibited between crossed nicols.

In the gromnd-mass oecur olivines and augites of the same charater as the plenocrysts, together with magnetite and ilmenite in grains or rod-like slieletal crystals, sharply defined felspar-laths, and, in many cases, brown glass.

The structure varies from pilotaxitic to hyalopilitic; in some of the rocks fluidal strurture round the larger phenocrysts of olivine is well marked.

The felspar-laths are of labratorite, giving symmetrical extinctions of abont $25^{\circ}$. Only rarely is a much-comoded small phenocryst of felspar seen in these rocks. In some line-grained basalts (e.\%., 180, from the top of the 900 -foot knoll at ('ape Crozier, and 311 , from White Island) the phenocrysts are very sparingly distributed. In these rocks olivine oceurs very plentifully in the ground-mass, cither as small rhombie sections or- (in specimen 180) as long prismatic erystals, not easily to le distinguished in ordinary light from the lath-shaped felspars. In some specimens (220) angite-phenocrysts ane seen to have been formed round magnetite-pseudomorphs after homblende. In others (335) unaltered hornblende oceurs as plenoerysts in addition to the augite and olivine.

* See Miigge, I'etrog. Untersucl. an Gest. v. d. Azoren. Neues Jahrb. 1883 (ii), 1. 221. 
A basalt (431) from the foot of Castle Roek contains curions opaque white inclusions up to 2 inches in diameter. They appear to be fragments of sandstone caught up in the lava; but if so they have suffered extreme metamorphism. The basalt has permeated them in thin blaek vesienlar glassy veins. The inclusions eonsist of a hard, minutely vesieular, glass whieh is colourless except at the aetual contaet with the basalt, where it becomes brown and nearly opaque. The glass incloses a few small scattered irregular grains of quartz and felspar, and is erowded with minute needle-like mierolites, and, nearer to the basalt, with larger needles of eolourless augite, such as have been deseribed in the ease of sandstone metamorphosed by basalt.*

The results of ehemieal analyses of the olivine-basalt (656) from near the Gap, and of a limburgite-like roek (326) from Ridge Road, near Winter Quarters, are as follows under I and II respectively $\uparrow:--$

\begin{tabular}{|c|c|c|c|c|c|c|}
\hline & & $\begin{array}{l}\text { I. } \\
(656)\end{array}$ & $\begin{array}{c}I_{A_{.}} \\
\text {mol. ratios. }\end{array}$ & $\begin{array}{c}\text { II. } \\
(326)\end{array}$ & $\begin{array}{c}\text { III. } \\
\text { (Gräveneck) }\end{array}$ & $\begin{array}{c}\text { IV. } \\
\text { (Härtlingen.) }\end{array}$ \\
\hline $\mathrm{SiO}_{2}$ & $=$ & $42 \cdot 14$ & $\cdot 698$ & $42 \cdot 10$ & $41 \cdot 17$ & $44 \cdot 14$ \\
\hline $\mathrm{TiO}_{2}$ & $=$ & $4 \cdot 90$ & $\cdot 061$ & $4 \cdot 93$ & $3 \cdot 08$ & $1 \cdot 34$ \\
\hline $\mathrm{Al}_{2} \mathrm{O}_{3}$ & $=$ & $14 \cdot 95$ & $\cdot 146$ & $14 \cdot 87$ & $13 \cdot 24$ & $19 \cdot 87$ \\
\hline $\mathrm{Fe}_{2} \mathrm{O}_{3}$ & $=$ & $2 \cdot 90$ & $\cdot 018$ & $3 \cdot 26$ & $3 \cdot 50$ & $11 \cdot 73$ \\
\hline $\mathrm{FeO}$ & $=$ & $9 \cdot 71$ & $\cdot 135$ & $9 \cdot 76$ & $12 \cdot 50$ & $4 \cdot 78$ \\
\hline MnO & $=$ & 0.12 & & $0 \cdot 07$ & & \\
\hline $\mathrm{CaO}$ & $=$ & $10 \cdot 82$ & $\cdot 184$ & $10 \cdot 63$ & $10 \cdot 24$ & $10 \cdot 86$ \\
\hline $\mathrm{MgO}$ & $=$ & $9 \cdot 47$ & $\cdot 285$ & $8 \cdot 88$ & $8 \cdot 21$ & $7 \cdot 23$ \\
\hline $\mathrm{Na}_{2} \mathrm{O}$ & $=$ & $8 \cdot 27$ & $\cdot 058$ & $3 \cdot 20$ & $2 \cdot 57$ & $3 \cdot 25$ \\
\hline $\mathrm{K}_{2} \mathrm{O}$ & $=$ & $1 \cdot 80$ & $\cdot 019$ & $1 \cdot 80$ & $1 \cdot 60$ & $1 \cdot 54$ \\
\hline $\mathrm{P}_{2} \mathrm{O}_{5}$ & $=$ & $0 \cdot 40$ & $\cdot 003$ & 0.58 & $0 \cdot 53$ & 0.80 \\
\hline $\mathrm{H}_{2} \mathrm{O}$ at $110^{\circ}$ & $=$ & $0 \cdot 12$ & & $0 \cdot 11$ & & \\
\hline $\mathrm{H}_{2} \mathrm{O}$ above $100^{\circ}$ & $=$ & $0 \cdot 16$ & & $0 \cdot 12$ & $3 \cdot 21$ & $1 \cdot 87$ \\
\hline S & $=$ & & & & $0 \cdot 09$ & \\
\hline $\mathrm{CO}_{2}$ & $=$ & & & & $0 \cdot 64$ & \\
\hline & & $100 \cdot 26$ & & $100 \cdot 31$ & $100 \cdot 64$ & $101 \cdot 41$ \\
\hline
\end{tabular}

The two results are almost identical, showing that probably most of the limburgitelike roeks only differ from the other olivine-basalts by their mueh more glassy base, in which little felspar has been developed.

For comparison with these results are given under III an analysis by Senfter of a "hornblende-diabase" of Devonian age from Grüveneck, Nassau, which was described by Streng; $\$$ and under IV an analysis by Sommerlad of a Tertiary hornblendebasalt from Härtlingen, Westerwald.\$ The elose similarity between I and III extends even to the very high percentage of titanie acid.

Olivine-basalts were found on Mount Terror, at Cape Crozier (830, 222, 218); and near Winter Quarters, at the Sulphur Cones (383) aeeompanying the homblende-

\footnotetext{
* Dannenberg, Tschermak's Min. Petr. Mitth, 1895, Bi. xiv, p. 58.

$\dagger$ For discussion of the analyses see p. 119.

‡ Streng, Ber. oberhess. Ges. f. Nat. u. Heillkunde, 22, 1883, p. 248.

§ Sommerlat Neues Jalırb., 1883, Beil.-bd. ii, p. 165.
} 
basalts, Castle Roek (431, 319), Crater Hill (341), Harloour Heights (323, 325, 366), and between the Gap and Horseshoe Bay (656).

specimens of the more glassy limburgite-type were obtained from the same localities, and also from Turtle Back Island (449) and Dailey Islands (510).

The basalt (553) from Cape Armitage has microseopic eharaeters preeisely similar to those of the basalt (656) from hetween the Gap and Ilorseshoe Bay, and is probably the prolongation of that rock mentioned on p. 12 of the Report on the Field-geology.

The bombs found on Harbour Heights (367, ete.) consist of olivine-basalt like that of the lavis.

The results of the analyses both of the hornblende-basalt and of the olivine-basalts indicate that nepheline is present in these rocks, either in the interstices of the felsparlaths or potentially in the glassy base. Generally it eould not be reeognised with ecrtainty under the mieroscope, but in a basalt (718) from the scree-slope below Catherlral Rocks eould be distinguished in the ground-mass small colourless patches of isotropic analeite (?), and of doubly-refraetive nepheline of which the refraction was about the same as that of Canada balsam. This rock, which showed under the microscope small phenocrysts of pale-purple augite and rounded olivines in a groundmass of felspar-laths, augite and magnetite, has a mueh closer relationship to the reeent hasalts of the Ross Archipelago than to the dolerites of the Ferrar Glacier.

Analeite is probably present in some of the other basalts which show small amounts of colourless isotropic material in the base, $e . /$, spccimens from Cape Adare (49), from Little Razor Back Island (471), and from the top of Castle Rock (319).

As a connecting link between the olivine-basalts with no porphyritic felspars and the alkaline rocks (lienytes) with porphyritic anorthoclases, to be deseribed in a later Seetion (p. 110), are a few specimens of basalt showing conspicuous phenocrysts of felspar.

These come from Black Island (593), the débris-heap off Mimna Bluff (619), Inacressible Island (805), Turtle Back Island (484, a boulder), and Cape Barne (814). They show numerous phenoerysts of clear glassy felspar in a ground-mass of felsparlaths, magnetite in grains and rods, pale-purplish augite and a little olivine. The rocks resemble the kenytes, but the felspar-phenocrysts lave not the eharacteristic shape of the anorthoclases; instead, they consist of an acid labradorite or andesine, having a specific gravity of $2 \cdot 68$, and showing an extinetion on $b(010)$ of about 16. In the case of the houlter (484) from Turtle Back Island, these plienocrysts are so flattened that the rock appears to be composed of altemating white and black layers.

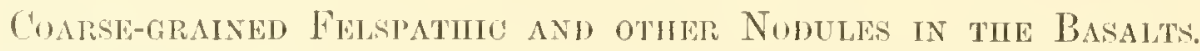

$\Lambda$ striking feature in the lasalts of the lioss Mrehipelago, especially in those of limburgite-type, is the number of included coarse-gramed nodules. These were found plentifully, not only cnclosed in basalts hut also in loose lumps, in the neighbourlood of Winter Quinters. 
Some of them are of the usual type common to many basalts, and eonsist mainly of olivine and enstatite, with brilliant green ehrome-diopside, like the nodules in the limburgite of Franklin Island.*

Other's, however, differ from most of those previously deseribed in consisting to a large extent of plagioclastic felspar, and thus have the charaeter of gabbros rather than of peridotites. $\uparrow$

Such gabbro-like nodules were found in the hormblende-basalt (385) from the Sulphur Cones, and in the limburgites from the neighbourhood of Winter Quarters $(408,316,335,415)$, as well as in the hasalt (375) from. Harbour Heights to which reference has been male in the Report on the Field-geology (p. 13).

In the latter roek many of the inclusions, as stated by Mr. Ferrar, are quite angular. In faet, some of them appear to be only loosely held in the basalt, like fragments eaught up in the molten mass. In most of the other speeimens, however, the nodules present the more usual rounded appearanee, and are completely enelosed by the basalt. In some eases (385) the junction is perfeetly sharp, and the roek shows muler the mieroseope no variations in strueture or eomposition in the neighbourhood of the nodule. In other cases (335) the basalt has obviously permeated the nodule in thin veins. This nodule (335) is eomposed mainly of pale-green angite, enstatite and olivine, but contains also a little basaltie hornblende and hiotite, and some plagioclastie felspar in broad plates. Where the basalt has permeated the nodule, the augite-plates have been eonverted into aggregates of small grains which bear some resemblance to the bronzite-chondrules in meteorites. 'The hornblende in the norlule may possibly have been derived from the basalt, whieh eontains phenoerysts of similar homblende; the biotite also may have resulted from the interaetion of basalt and nodule; but the felspar ean hardly be coneeived to owe its origin to the basalt, sinee the latter is of distinetly limburgite-type, showing under the mieroseope little or 110 felspar. Moreover, the most felspathie nodules of those examined, viz., 385 and 316 , show no signs of having been attacked by the enclosing hasalt.

These two felspathie nodules consist of granular aggregates of plates of labratorite, giving symmetrical extinctions of $20^{\circ}-30^{\circ}$, and irregular crystals and corroded patches of nearly eolourless augite laving a roughly parallel arrangement; a little olivine is also present in speeimen 385. Under the mieroseope the pale yellowish-brown angite has a rough, dirty appearanee due to numerous inelusions. These eonsist for the most part of gas-bubbles, glass and opacite, but some fantastieally-shaped ones are probably liquid inelusions. One crystal showed long black needles arranged in parallel lines, like those observed by Dannenberg in angite-nodules in the basalts of the Rhine. The felspars in these nodules also enclose numerous gas-bubbles.

* Prior, Rep. 'Southern Cross' Collections (British Museunn), 1902, p. 328.

† Felspathie norlules in the basalts of the Siebengebirge have leen deseribed, see Dammenberg, Tsehermak's Min. Petr. Mitth., 1895, 13l. xiv, p. 35 ; Laspeyres. Verh. naturl. Ver. pr. Theml., 1900, Jahrg. lvii, p. 194; and Zirlsel, Abhand, math.-phys. Cl. d. liönigl. sïchs, Ges. d. Wiss, 1903, Bd. xxviii, p. 165.

$\ddagger$ Damenberg, l.c. p. 40 . 
A nodule (342) found near the ship, and consisting of pale-green diopside, grains of clear olivine and plates of labradorite, showed a few dull-green isotropic grains of picotite. In another somewhat similar nodule (478), from below Castle Rock, occurs a little hypersthene, showing straight extinetion and pleochroism from pale-pink to pale-green.

The nodule (415), which is represented in scetion in Plate VIII, Fig. 2, was enelosed in a hornblende-limburgite from between the Gap and the ship. It consists of a granular aggregate of labradorite and pale-green diopside, with smaller grains of altered olivine and a little basaltic hornblende. The labradorite shows symmetrical extinctions of $23^{\circ}-26^{\circ}$, and encloses numerous gas-bubbles. The olivine grains are red with oxide of iron, which is often arranged in bundles of wavy threads erossing each other at right angles; probably these threads were originally of magnetite, like the inclusions in the olivine-nodules deseribed below.
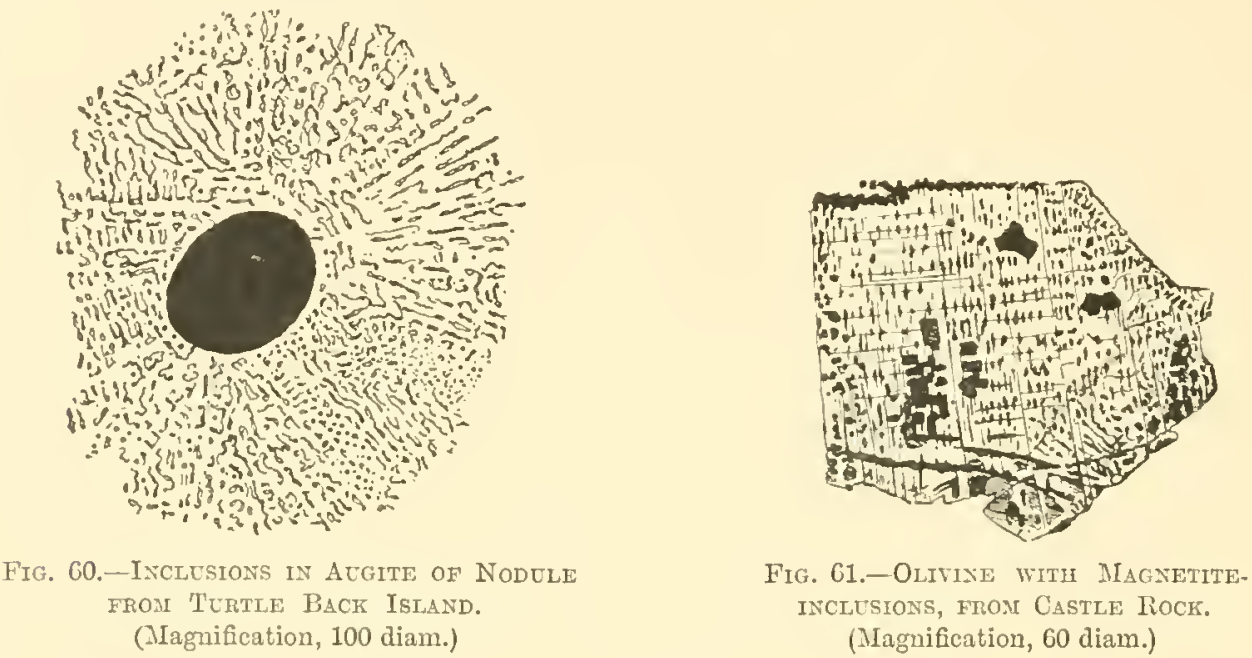

Of the non-felspathic nodules, one (180, from the 900 -ft. knoll on Mount Terror) consists of olivine, enstatite, and purple titaniferous augite; anotlier ( 438 , from IIarbour Heights) almost entirely of clear', colourless olivine and enstatite; while others are composed wholly of olivine impregnated with magnetite. A nodule (or possibly a bomb) from the south slope of Turtle Back Island eonsists mainly of smoky-black augite, and shows only a little yellow olivine in bands. Under the microseope the augite shows some plcorhroism from pale smoky-purple to brownish yellow, and has numerous gas and vermiform liquid (?) inclusions arranged in lines; in one crystal a halo of fantastically-shaped inclusions surrounds an included dark rounded grain (sce Fig. 60).

Some of the nodules in the hasalt near Winter Quarters (375 and 437) are of dark ironstone-like appearance. They were found to consist wholly of olivine-grains densely impregnated with maguetite, and thus resemble the olivine-phenocrysts in the basalt (366) from Harbour Heights (see p. 104). Under the microscope one of these 
grains showed an obtuse negative bisectrix, being eut parallel to 010 . In this case the magnetite is seen to be arranged in lines parallel to the (100) cleavage, and also in more wavy lines approximately at right angles to the first; along the latter lines the magnetite occurs in blobs, which are flattened out at right angles along the more definite eleavage (sce Fig. 61). This olivine with included magnetite is very similar to that figured by Tsehermak in the Sierra de Chaco meteorite.*

The origin of the so-called "olivine-nodules" in basalts has heen the subject of much discussion. $\dagger$ The presence in these Antarctic rocks of felspathie gabbro-like nodules as well as those having the composition of peridotites is of interest, since the general absence of felspar in "olivine-nodules" has been used as an argument against the theory that they are intratelluric separations from the magma.

\section{Basalts and Dolerites froy Auckland Islands and Macquarie Island.}

The specimens brought back from Auckland Islands are olivine-basalts similar to those collected by the Ross Expedition and described by the present writer in Mineralogical Mag. 1899, vol. xii., pp. 70-73. Those with conspicuous phenocrysts of olivine and augite resemble the olivine-basalts of Cape Adare and the Ross Arehipelago.

The dyke-rock (893) from Williamson Point shows under the mieroscope large and much-corroded crystals of colourless olivine and pleochroie (purple to yellow) titaniferous augite in a basc of felspar-laths, purple augite, and magnetite in grains and skeleton-crystals.

The basalts from Macquaric Island are of a somewhat different type. They are much more altered than the rocks of the Aucklind Islands, and appear to be of greater age.

The more coarse-grained rocks $(1,5,6)$ are diabasie in character, and consist of a medium-grained aggregate of felspar-latlis, colourless augitc (sub-ophitic), large magnetite-grains, sparingly distributed, and interstitial green chloritic and hornblendic alteration-products. The rock (4) from "100 yards up the stream" (see p. 96) shows large phenocrysts of labradorite and a few chloritic pseudomorphs after olivine. The crushed rock (9) is a much-altered andesitic basalt showing large phenocrysts of lahradorite in a very fine-grained altered base.

\section{BASALT-TUFFs.}

Fragmental basaltic rocks were found in most of the localities on Ross Island where bare rocks are exposel, viz., Cape Crozier, V-Clift's Hogsback, Sultan's Itead, Castlc Rock, The Turk's Ilead and IIutton Cliff's.

The pale-yellow tuff from Sultan's Head contains numerous black fragments of vesicular basalt which show under the microscope a few sharply defincel felspar-laths and grains of olivine in a glassy base dense with magnetite. The tuff, however,

* Tschermak, Mikr. Beschaff. Mcteoriten, 1885, Lief. III, Pl. XXIII, Fig. 4.

$\dagger$ Sce Zirkel, Lehrbuch d. Petrographic, 1s94, Bd, il, p. 931; and Abhand. math.-phys. Cl. 1. kgl. sïchs. Ges. d. Wiss. 1903, Bd. xxviii, p. 103. 
consists mainly of fragments of resicular basalt-glass imbedded in a base of angular grains of orange-yellow paligouite with a little magnetite and small felspars; in parts this fragmental material is ecmented with ealcite. In the fragments of hasalt-glass, all of which have been converted into palagonite, magnetite has separated in fairly distinct crystals, and the felspar-laths and olivine-grains which the glass eontains are fresh and unaltered.

The tuff from Castle Rock is of similar character; in the fragments of basaltglass, however, much purplish angite, besides olivine and felspar, has been developed; the felspar also oceurs in thin, broad plates as well as in laths. In the basalt-glass of the tuff' from Cape Crozier, on the other land, no felspar las been developer, but it shows sharply defined erystals of olivine and purplish augite.

The tuffs from the "Bare Rocks" at Hutton Cliff's in Erebus Bay differ remarkably from the others in appearance and general character. They are of a dull-green colour,

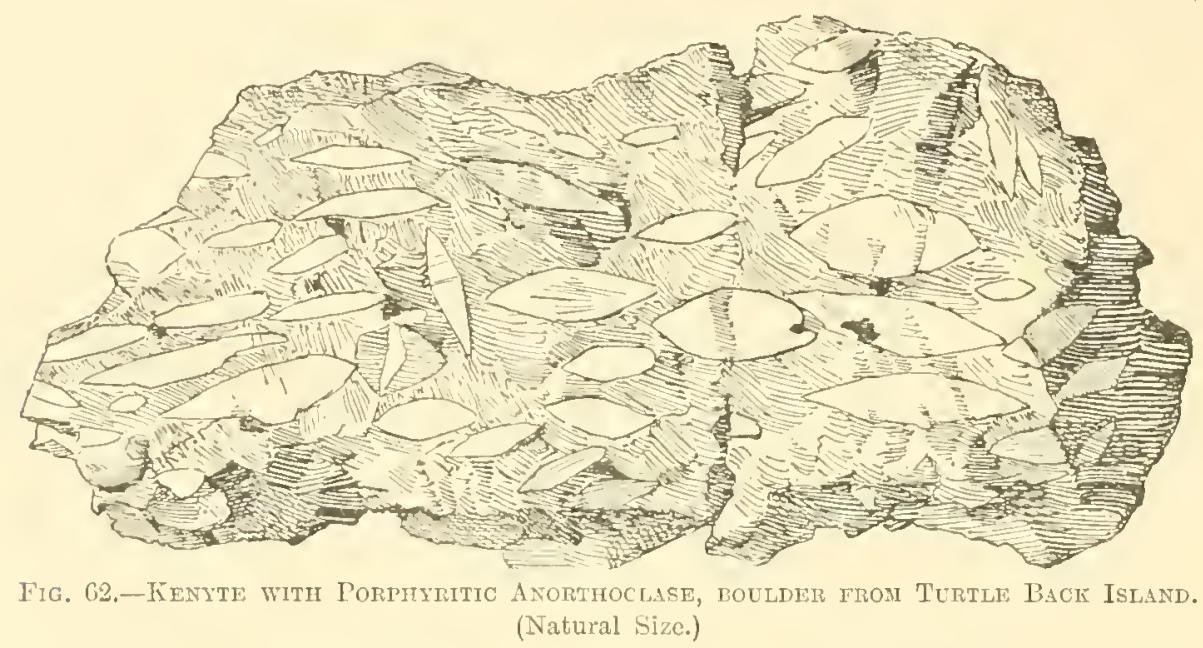

ancl are much more compact, so much so that it is wot easy with the unaided eye to recognise their fragmental nature. They have the appearance of greater age than the other tutls, and show under the microseope that they have been much altered. They consist mainly. iike the other tuffe, of a very vesicular basalt-glass, hut in this case the ghass has been converterl into a dull-green chloritie or serpentinous alteration-produet instear of into yellow palagonite, and most of the crystals and nicrolites of angite and olivine have been obliterated; unly rarely is seen a fragment of vesienlar lasalt-glass in which small prisnatic: purplish augites can be reeognised. The tuff' contains larger fragments of a less glassy nou-vesionlar besalt, showing under the mieroscope lathshaperl folspars and magnetite in skeleton-erystals, with green altered ferromagnesian minerials.

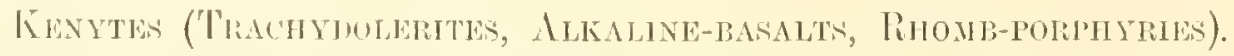

From the slopes of Mount Freluns and the islants in Erelous Bay conte the remarlable rocks mentioned on p. 10\%. 'These are distinguished from the basaltie 
rocks of Mount Terror and Winter Quarters by their ummerous and large $(2-3 \mathrm{~cm}$. in length) porphyritie lozenge-shaped crystals of anorthorlase, resembling those of the well-known rhomb-porphyries of Norway (see Fig. 62). They are alnost precisely ilentical in eharacters and ehemical composition with the lienytes of Ilount Kenya, and the description recently published by Dr. Finckh of the rhomb-porphyries (kenytes) of Kilimandjaro $f$ could be followed almost word for word in an account of these Antaretie rocks. They are alkaline basalts or trachydolerites (Rosenbusch), intermediate in type between ordinary basalts and phonolites.

In colour they vary from dark-gray, to nearly black in the more glassy varietics. Under the mieroscope they show, besides the large phenocrysts of anorthoclase, small rounced olivines and pale-gray or brown to pale-purple augites sparingly distributed.

In different specimens the ground-mass varies in texture, and to some extent also in mineral composition. In some (812 from the Skuary) it is quite holoerystalline, and consists of a trachytic mesh of interlacing felspar-laths (mainly anorthoclase) with interstitial shreds and small prismatic erystals of a palegreen augite and grains of magnetite; in others (464 from Tent Island) it is a brown glass, dense with magnetite in grains or rod-like skeleton-erystals, but showing in elearer palebrown streaks minute mierolites of felspar ind angite. In the boulder 447 from Turtle Back Island, the glassy base is confusedly spherulitic with minute magnetite-grains arranged in raliating wary lines. In Fig. 63 is represented a spherule with the black eross as seen between

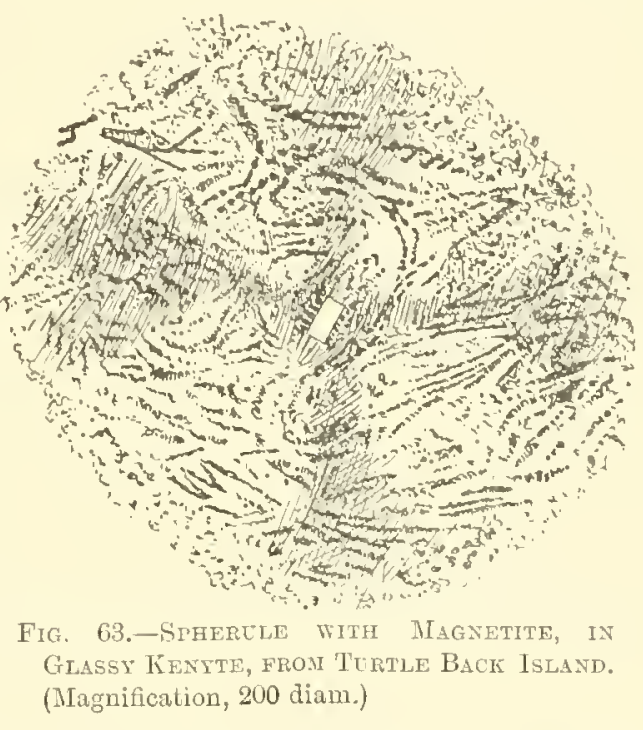
erossed nicols. The glass in the base of specimen 541 from the slope of Mount Erebus is almost colourless, but in parts is rendered nearly opaque with fine dusty magnetite; in the clear brown glass, however, which is inchuded in the anorthoclase-phenocrysts of the same roek there has been no separation of magnetite exeept round the edges, from which project long, eolourless, needle-like microlites of augite.

The rocks from Cape Royds $(818,820)$ present a distinet varicty eharacterised by the presence of leucite. They show large phenoerysts of anorthoclase and, very sparingly, small rounded olivines, like those in the other kenytes, but contain in the ground-mass fairly numerous, small, rounded, isotropic crystals of lencite having eharaeteristic eentral and marginal inclusions of the magnetite and augite of the base (see Plate VIII, Fig. 3). These rocks are therefore similar to the leneite-rhomb-porphyries

* Gregory, Quart. Journ. Geol. Soc., 1900, vol. lvi, p. 205.

† Finckh, Festschr. z. siebzigsten Geburtstage ron Hany Fosenhusch, 1906, pp. 378-397. 
of Kilimandjaro described by Finckh. * The leueites show a refraction marliedly less than that of Cinada balsam. In most of the small erystals the central inclusion of base ocenpies the greater part; in many also the outer edge is invaded by the minute felspar-aths which generally form a fringe round the crystal. That the leucitic material in these rocks is only in small amount is indieated by the result of the bulkanalysis (sec p. 113), and more especially by the partial analysis of the part soluble in nitrie aeil, the result of which is as follows, under I :-

$$
\begin{array}{lccc} 
& \multicolumn{1}{c}{\text { I. }} & & \begin{array}{c}
\text { II. } \\
\text { (Nephelino.) }
\end{array} \\
\mathrm{SiO}_{2} & =43 \cdot 12 & \ldots & 43 \cdot 74 \\
\mathrm{Ml}_{2} \mathrm{O}_{3}, \mathrm{Fe}_{2} \mathrm{O}_{3} & =3.3 \cdot 3.2 & \ldots & 81 \cdot 48 \\
\mathrm{C}_{3} \mathrm{O} & =2 \cdot 63 & \ldots & - \\
\mathrm{Na}_{2} \mathrm{O} & =11 \cdot 96 & \ldots & 16 \cdot 62 \\
\mathrm{~K}_{2} \mathrm{O} & =3 \cdot 7.3 & \ldots & 4 \cdot 56 \\
\mathrm{Cl} & =0 \cdot 70 & \ldots & - \\
\mathrm{H}_{2} \mathrm{O} \text { etc. (diff.) } & =\underline{(1 \cdot 54)} & \ldots & \underline{0.86} \\
& \underline{100 \cdot(00)} & & \underline{100 \cdot 25}
\end{array}
$$

The rock-powder gelatinised readily with acids, and as much as $25 \%$ was decom-. posed by half an hour's digestion with dilute (1:5) nitric acid. Under II is given, for comparison, the result of an analysis by Clarke of a nepheline from Litehfield, Maine.

The result of the above analysis suggests, therefore, that the soluble portion of the rock consists mamly of nepheline.

An attempt was made to separate the lencites in the rock-powder by means of heavy liquids, but the grains which floated in a liquid in which moonstone sank and leucite floated were in very small amount, and of these only a few remained dark between crossed nicols.

The anorthoclase-phenoerysts in all these rocks have the characteristic lozengeshape determined by the development of the faces MI (110), m (110), and y (201). They alnost invariably show minute twin-striations, occasionally in two rectangular directions according to the albite- and perieline-laws. Like the similar phenoerysts in the kenytes of Mount Kenya, they contain numerous inclusions of glassy base, and also occasionally inclusions of olivine, augite, apatite, and magnetite or ilmenite. On this areount no chemical analysis was attempted. In pliysical characters they agree perfectly with the anorthoclases of Pantelleria and Kilimandjaro. The specifie gravity is $2 \cdot 62$. ('leavage-flakes parallel to $b(010)$ show a positive bisectrix, slightly inclined, and give an extinction-angle with the trace of $c(001)$ of abont $6^{\circ}$, while cleavage-flakes parallel to $c(001)$ have extinctions of ahout $1^{\circ}$. The refraction was alout the same as that of rlove-oil (1-538). Wolft' (quoted by finckh) found the value of $\gamma_{\text {ma }}$ for the anorthochase of Kilimameljiro to be 1.5376 .

Nepheline was not found as phenocrysts in these rocks, neither could it be with certainty deteeted in the hase, but that it is present is indieated ly the resnlts of the Inlk-inlalysis.

$$
\text { * Finclih, l.c., p. } 382 .
$$


The olivine-phenocrysts oceur very sparingly, and are generally less than $1 \mathrm{~mm}$. in liameter; they are clear and colourless, and often contain inclusions of apatite and magnetite. 'T'hey are generally of irregular and sometines of perfectly round outline: only occasionally is one seen with distinet erystalline shape. Intergrowths of augite and olivine oecur, and in one case augite was seen to he enclosed in olivine.

Augite-phenoerysts oceur even more sparingly than the olivines. They are generally without distinct erystalline outline, and consist of a pale-gray or hrown augite having angles of extinction of over $40^{\circ}$. In a specimen (837) of glassy kenyte from a moraine at the "mouth of 'znd Alpine Talley," in Discovery Gulf, the angitephenocrysts are in larger amount, and attain a length of 2 to $3 \mathrm{~mm}$. : usually they are less than 1 1mm. in length. The augite of the ground-mass oecurs generally in small prisms of a pale-gray to green colour, but in some specimens this is replaced to sone cxtent by grass-green agirine-augite.

A patite is fairly plentiful in these rocks; often it is of a pink coloul, and dense with dark inclusions arranged in lines parallel to the length of the neelles.

A chemical analysis of the leucite-kenyte (818) from Cape Royds gave the following result under I*, as compared with that of a kenyte from Mlount Kenya under II†, a lencite-kenyte ("leucite-rhomb-porphyry") from Kibo (Kilimandjaro) under lll+, and a nepheline rhomb-porphyry from Vasvik, Norway, under IT:-

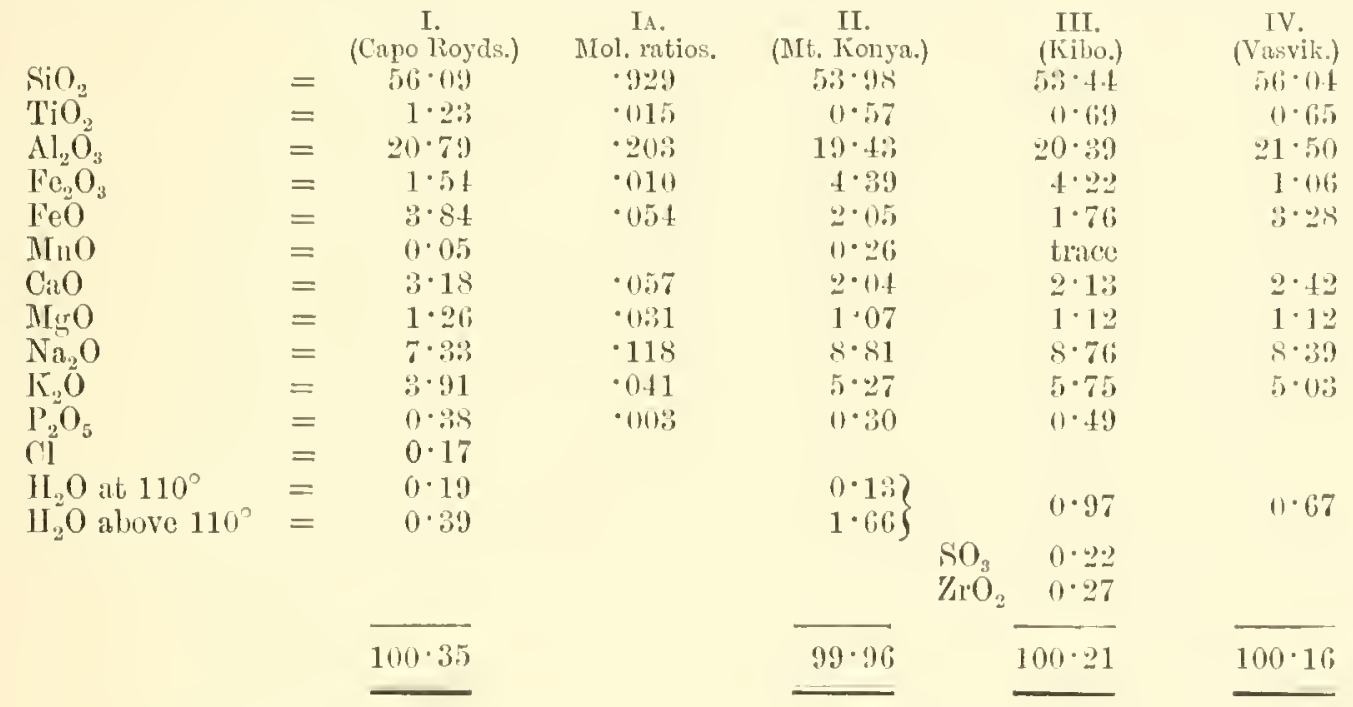

Pilonolitic 'Trachytes ('Trachydolerites) and Phonolites.

Most of the rocks which are here included under the name of trachyte are of a somewhat basie type, and so clusely related in ehemieal composition to the preceding alkaline basalts or kenytes that some hesitation is felt in separating them; with the kenytes they might all be elissed under the trachydolerite group of Rosenbusch.

'These trachytes are pale ash-graly compact rocks; but weathered specimens (iu

* For discussion of analyses, sec p. 119.

+ Prior, Mincralogical Magazine, 1903, rol, xiii, 1) 2.7.

VOL. I.

$\ddagger$ Finckh, l.c., p. 392. 
which the augite of the ground-mass, together, apparently, with some of the magnetite, has been altered, with development of orange-yellow epidote) are of a pale-yellow or pink colour. They differ from the kenytes in showing either no phenoerysts of anorthoclase or only few and small ones.

Those which approximate most closely to the kenytes show under the microseope an oceasional small rounded phenocryst of olivine and augite in a ground-mass consisting of a mesh of felspar-laths, with interstitial irregular grains and shreds of dull-green augite, needles of pleochroic (ycllow to dull-green) regirine-angite, and only a few magnetite grains. The felspar-liths are not sharply defined, and are often associatel with more platy felspars; they have a refraction not greater than clove oil $(1 \cdot 538)$, and consist mainly of anorthoclase. That nepheline is present in these rocks is probable, although it eannot with ecrtainty be recognised under the mieroscope.

To this type belong specimens 80t, from Inaccessible Island, and 473 , from Little Razor Back Island.

The specimens collected by the 'Morning' from Scott Island and a trachyte (188) from the top of the 900-ft. knoll at Cape Crozier are of similar character, but show no porphyritic olivines and augites in the thin slices examined. The rock from Cape Crozier is of a lighter-gray colour and of more salie character than the specimens from Scott lsland; it shows the peculiar surface-shimmer, due to the parallel arrangement of the platy felspars, which is so characteristic a feature of many of the allialine roeks of Norway (solvsbergites) descrilued by Brögger."

A coarse-grained inclusion in this trachyte (188) consists of an aggregate of stont felspar-prisms, with some pleochroic (yellow to grass-grecn) agirinc-augite and a little cossyrite-like hornblende showing pleochroism from redish-brown for vibrations across the length to black for those along the length; the felspars are partly oligoclase with symmetrical extinctions of about $8^{\circ}$, and partly anorthoclase.

The results of chemical analyses of the rock from Scott Island, and of the traclyte from - Cape Crozier (188) are given under I and II respectively. $\dagger$ They show the close chemical relationship between these rocks and the leueite-kenyte, the analysis of which is given on p. 113.

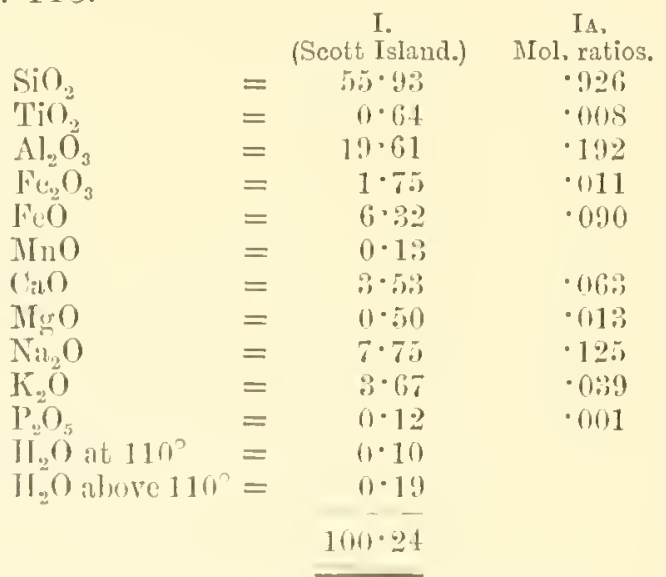

\begin{tabular}{|c|c|}
\hline $\begin{array}{c}\text { II. } \\
\text { (Cape Crozier.) } \\
5 \% \cdot 1)\end{array}$ & $\begin{array}{l}\text { IIA. } \\
\text { MIol. ratios. } \\
\text { - !iv! }\end{array}$ \\
\hline$(0 \cdot .10$ & $\cdot 005$ \\
\hline $20 \cdot 13$ & -200 \\
\hline $3 \cdot 13$. & $\cdot 022$ \\
\hline $1 \cdot 3 \overline{5}$ & $\cdot 0 \geq 0$ \\
\hline $0 \cdot(17$ & \\
\hline $1 \cdot 96$ & $\cdot 0.34$ \\
\hline$(1 \cdot 26 ;$ & $\cdot 006$ \\
\hline $8 \cdot: 3: 2$ & $\cdot 13.1$ \\
\hline $5 \cdot 96$ & $\cdot(16 ; i)$ \\
\hline $0 \cdot 17$ & $\cdot 001$ \\
\hline $0 \cdot 293$ & \\
\hline (1) $\because: 9$ & \\
\hline $10(0) \cdot 76$ & \\
\hline
\end{tabular}

* Hröggel, Eruptivgestcine des Krristianiagebietes, 1894, I, p. 76.

$\dagger$ For discussion of the analyses sec p. 119. 
Closely related to the preceding, but of a more definite trachytie type, are other ash-gray rocks, which show under the microscope small, sharply defined rectangular phenoerysts of anorthoclase in a ground-mass consisting of a trachytic mesh of felsparlaths, with interstitial dull-green segirine-augite and a little magnetite (see Plate VIII, Fig. 4). The felpar-phenocrysts show the minute twin-striations characteristic of anorthoclase, and similar striations can also be detected in some of the larger felsparlaths of the base. The xgirine-augite is in small, prismatic crystals, and shows pleochroism from brownish yellow to dull-green.

To this type belong most of the ash-gray or yellow (when weathered) trachytic rocks from Cape Crozicr $(248,224,251,243$, etc.), as well as specimens from Inacessible Island $(802,303,807)$, Brown Island $(598,600)$, and Black Island $(61.0)$.

Of almost prcciscly similar character to the rock (248) from Mount Terror (Plate VII, Fig. 4) are trachytic rocks (55) obtained from the dredge off Cape Wadrorth, Coulman Island.

Of extremely salic character is the phonolitic trachyte (607) from the middle of the crater of Brown Island. It is a white, friable rock, rescmbling a domitc. It consists of a fine-grained aggregate of small felspars (mostly short rectangular, but some lathshaped) without flow-structure, in the interstices of which are distributed a few magnetite-grains and, very sparingly, needles of dull-green segirine-nugite; a few grains of egirine and small crystals of sphene are also present. The felspars have a refraction near that of Canada balsam, and are doubtless mainly anorthoclase. With a high power, under the mieroseope, are seen numerous minute and very thin hexagonal and square sections of an undetermined mincral, which is isotropic or only very fecbly doubly-refracting, and has a refraction markedly less than that of Canadia balsam. That nepheline is present in the hase, although it cannot be definitely distinguished, is indicated by the chemical analysis of the rock, the result of which is as follows under I*:-

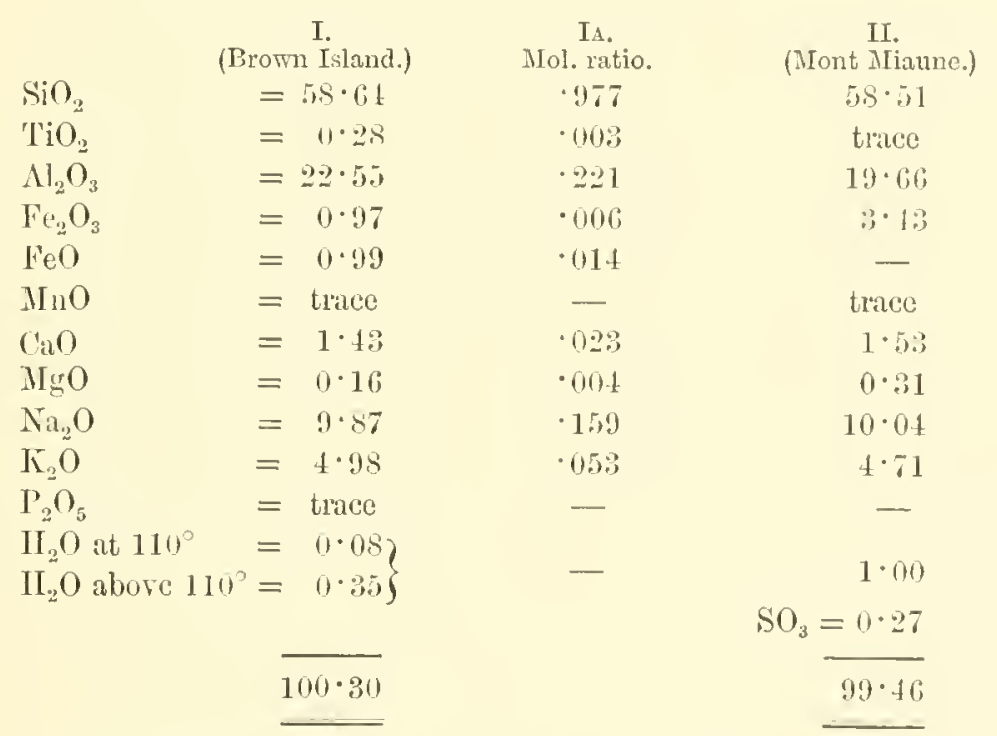

* For discussion of the analyses, see p. 119. 
Under II., for comparison, is appended the analysis of a phonolite from Mont Miaune, Velay, France.*

More closely approaching phonolites are rocks from the débris-heaps at Minna Bluff (613) and from Black Island (530).

Specimen 613 from the Minna Bluff is a dark greenish-brown compact rock showing no phenoerysts. Under the microscope are seen feathery flakes of palegreen agirine-augite, and ragged tufts of cossyrite and of a brown altered mineral (probably another soda-hormblende or pyroxene). These are thickly and uniformly distributed in a rather unindividualised base, showing indistinct felspar-laths and a few magnetite-grains; nepheline is probably present in the base, but could not be definitely identified. The regirine-augite shows extinctions up to $37^{\circ}$, and pleochroism from pale grass-green for vibrations along the length to pale pinkishyellow for those across the length. The cossyrite has pleoeliroism from nearly colourless to deep purplish-brown or opaque; the shreds were too irregular to admit of a more precise determination of the optical characters.

The rock (530) from Black Island is nearly colourless. Under the microscope it shows (see Plate VIII, Fig. 5) a fine-grained trachytic felt of felspar-laths, with much decp-blue riebeekite-like hornblende scattered in minute shreds throngh the section, and accumulated in patches round small altered erystals of what was once probably nepheline. The riebeckite shows pleochroism from pale-brown to colourless across the length of fibres to indigo-blue along the length. These two rocks are similar to some of the phonolitic rocks of the Rift Valley, East Africa. $\uparrow$

Of phonolitic rocks closely related to the kenytes two specimens deserve mention, viz., a rolled pebble (25) from the beach at Cape Adare, and a dark-green compact rock (622) from Mimna Bluff (díbris-heap).

The pebble from Cape Adare is a dark-green compact phonolite showing numerous porphyritic felspars having the characteristic lozenge-shape of anorthoclase. Under the microscope, besides the large (up to $1 \mathrm{~cm}$. in length) phenocrysts of anorthoclase showing minute twin-striations, are seen a few small phenocrysts of deep reddish-brown hornblende, and more numerous pseudomorphs, after lormblende, consisting of grains of magnetite and deep-green rgirine-augite. The ground-mass consists of numerous shreds and small prismatic crystals of agirine-augite, like that in the hornblendepseudomorphs, evenly distributed in a base of felspar-laths (not sharply defined) and interstitial nepheline. Magnetite-grains occur very sparingly in the lase. A few small crystals of sphene are also present.

of somewhat similar composition is the dark-green phonolitic rock (622) from the Minna Bluff. It shows under the microscope numerous long prismatic phenocrysts of orthoclase and anorthoclase in a very fine-grained base consisting of a mesh of minute felspar-needles with globulites anr microlites of green agirine-augite. Small crystals

\footnotetext{
* Eimmons, On some l'honolites from Velay and the Westerwald. Dissertation, Leipzigr, 1874.

† I'rior, Mincralogical Magazine, 1903, vol. xiii, p. 237.
} 
of this mineral are also included in the porphyritic felspars, and oceur sparingly as phenocrysts. The anorthoclase-phenocrysts show no twin-striations, but have mottled extinctions; the refraction is not appreciably higher than that of Canada balsam.

The trachytic rocks of Observation IHill present a special type which approaches very closely to the "tephritic trachyte" of Forodada, Columbretes, described by Becke * and placed by Rosenbusch in the group of trachydolerites.

The mineral which especially characterizes them is a reddish-brown basaltic hornblende similar to that which is present in so many of the basalts. This mineral occurs in small prismatic crystals, only occasionally large enough to be detected by the naked eye.

These trachytic rocks practically compose the whole of Observation Hill, near Winter Quarters. All the rocks lescribed on p. 13 of the Report on the Field-geology, both the slabby rocks $(281,291)$, the spheroidal rock $(655)$, the dyke-roek (275), and the yellow rocks (279, ete.), are very similar in microscopic characters, and only differ in the more or less glassy nature of the base or in the size and number of the hornblende-needles. The yellow rocks from the top of the hill appear to be only weathered gray rocks. In specimens showing alternating bands of gray and yellow (see p. 13) these bands show under the microscope a precisely similar and continnous mesh of felspar-laths, and only differ in the yellow bands containing plentiful yellow grains of epidote in place of the minute magnetite-grains and small dull-green augites of the gray bands. These trachytes show no phenocrysts of felspar, augite or olivine. Under the microscope are seen small prismatic crystals of basaltic hormblende (or of black magnetite-pseudomorphs after it) in a trachytic mesh of minute felspar-laths, showing generally well-marked flow-structure, with thickly disseminated grains of magnetite and small needles of pale dull-green augite.

In the dylie-rock (277) and in the dark rock (290) on the S. side of the hill the bornblende is less altered and in larger amount thin in most of the other specimens, and the flow-structure of the lath-shaped felspars is less pronounced (see Plate VIII, Fig. 6).

A black streaky rock with greasy lustre (264), half-way up the hill, is a glassy variety presenting some interesting features. Under the microseope it shows a few small prismatic hornblendes in a base consisting of a nearly colourless glass enclosing felspars, partly in sharply defined laths, but mainly in very thin hexagonal or nearly rectangular plates: small prismatic crystals, both of pale dull-green augite and of basaltic hornblende, and minute necdle-like microlites of augite with a very little magnetite, are also present. In parts of the slide occur groups of minute colourless circular or roughly six-sided and eight-sided isotropic crystals (Fig. 64). Though they appear to have a high relief, the Becke-effect shows that their refraction is less than that of Canada balsam, and they are here referred to leucite. Minute icositetrahedra

* Becke, Tschermak's Min. Petr. Mitth., 1896-7, Bd. xvi, p. 174. 
of loueite were foumd by Beeke in the glassy hase of the trachyte from Forodada.* The platy felspars in this rock have a refraction a little lower, and the lath-shaped felspars a refrution a little lighher, than that of Camata balsam. Mlost of the felspar is probably anorthoclase.

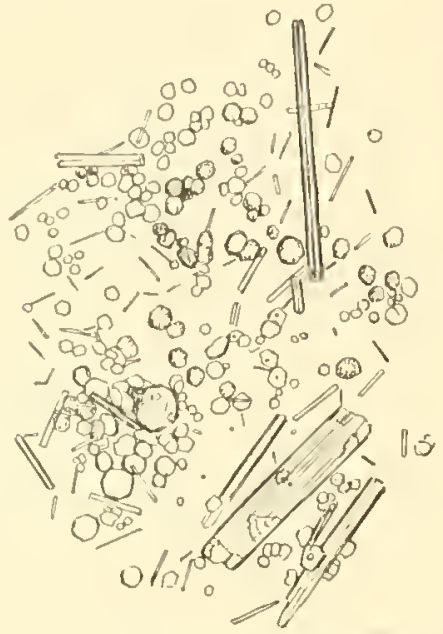

Frg. 64.-Lectite-cristals in Base of Glassy HORYBLEXDE-TRACHYTE (264), FROM OBSERVATION HILL. The prismatic erystals are mostly augite: the long one at the top is homblende. (Magnifieation, 150 diam.)

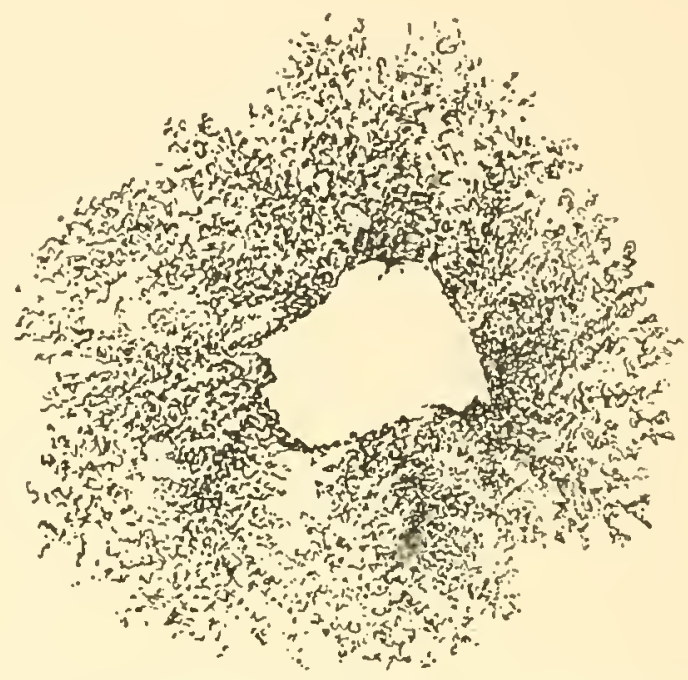

Fig. 65.-Dendritic Magnetite in Glasst Base of Trachyte from Observation Hill. (Magnification, 200 diam.)

Another very similar glassy valiety (42:) from between the ship and Observation Ifill shows under the microscope, throughout the slide, small dendritie patehes (sce Fig. 65) of magnetite (possibly altered rieleckite or other sola-homblende).

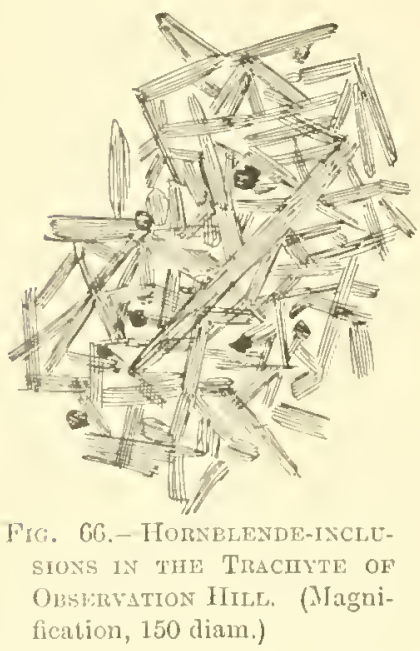

$\Lambda$ noteworthy feature of these trachytes of (Ohservation Hill is the presenee in many of them of dark "lapilli-like" enclosures. In the yellow rocks on the top of the hill these darli rounded enclosures, about the size of a hazel-nut, stand out on the weathered surface like fragments of black basalt canght up in the trachytc. Under the microscope, lowever, they are seen not to have the character of loasalt, lut to ronsist of a dense mesh of interlacing prisms of basaltic hornl)lende, similar to that in the trachyte, with magnetite-grains and only a little interstitial felspar (see Fig. 66). These enclosures are therefore somewhat similar to those described by Trecke $\dagger$ in the ease of the similar tephritic trachyte of Ferrera, Columbretes. The hornblende in these enclosures and in the trachytes has the characters of barkevikite and shows pleochroism, $a=$ ycllow: $\beta$ and $\gamma=$ leep reddish-lnown; the long prisms have straight extinction and compensate across their length with a quartz-wedge eut parallel to the optic axis.

* Becke, 1. e. p. 176.

† Becke, l. c., 1. 16, 8 and Taf, III, fig. 4. 
A ehemical analysis of the lomblende-trachyte (277) from Observation Ilill gave the result unler $I_{\text {** }}$ With this is eompared the analysis of the tepluritie trachyte from Forolada under II, $\uparrow$ and that of a traclydolerite (haiiyne-phonolite) from Campanario, Palma, under III.t

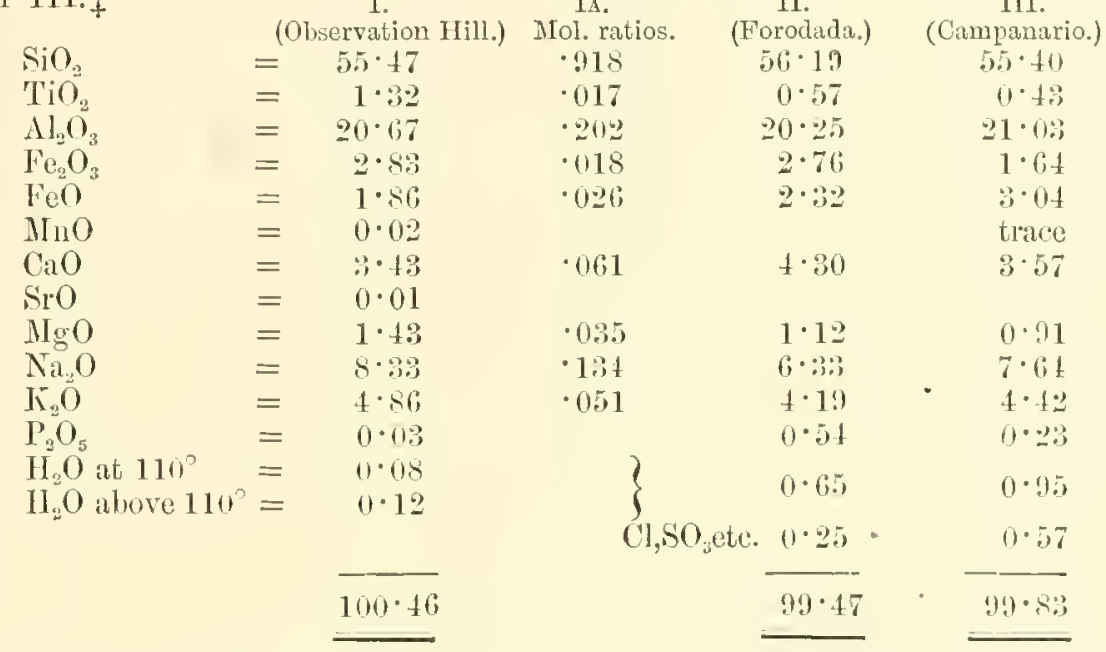

As in the case of the kenytes and the other trachytes, the analysis indicates the presence of nepleline which, however, could not be detected with eertainty in the base of the rock.

A determination was made of the silica-pereentage of the altered yellow trachyte (278) from the top of Observation Hill and gave the result $56 \cdot 96$.

\section{Cimenical Relations of the Preceding Tolcanic Rocks.}

For convenience of comparison the results of the analyses of seven of the rocks deseribed in the preceding pages are brought together in the following table. $\$$

\begin{tabular}{|c|c|c|c|c|c|c|c|c|}
\hline & & (1.) & (2.) & (3.) & (4.) & (5.) & (6.) & (7.) \\
\hline $\mathrm{SiO}_{2}$ & $=$ & $40 \cdot 14$ & $43 \cdot 92$ & $55 \cdot 47$ & $55 \cdot 93$ & $56 \cdot 69$ & $57 \cdot 95$ & 5.64 \\
\hline $\mathrm{TiO}_{3}$ & $=$ & $4 \cdot 90$ & $4 \cdot 19$ & $1 \cdot 32$ & $0 \cdot(; t$ & $1 \cdot 28$ & $0 \cdot 40$ & 0.28 \\
\hline $\mathrm{Al}_{2} \mathrm{O}_{3}$ & $=$ & $14 \cdot 95$ & $17 \cdot+2$ & $20 \cdot 67$ & $19 \cdot 61$ & $20 \cdot 79$ & $20 \cdot 48$ & $22 \cdot 5.5$ \\
\hline $\mathrm{Fe}_{2} \mathrm{O}_{3}$ & $=$ & $2 \cdot 90$ & $\pm \cdot 09$ & $2 \cdot 83$ & $1 \cdot 75$ & $1 \cdot 5 t$ & $3 \cdot 43$ & 0.97 \\
\hline $\mathrm{FeO}$ & $=$ & $9 \cdot 71$ & $8 \cdot 83$ & 1.86 & $6 \cdot 32$ & $3 \cdot 84$ & 1.35 & $(1 \cdot 99)$ \\
\hline $\mathrm{MnO}$ & $=$ & $(1 \cdot 12$ & $0 \cdot 09$ & $0 \cdot 02$ & $0 \cdot 13$ & $0 \cdot 05$ & $0 \cdot 07$ & trace. \\
\hline $\mathrm{CaO}$ & $=$ & $10 \cdot 32$ & $9 \cdot 53$ & $3 \cdot 49$ & $3 \cdot 53$ & $3 \cdot 18$ & $1 \cdot 90$ & $1 \cdot 43$ \\
\hline $\mathrm{S}_{1} \mathrm{O}$ & $=1$ & & & $0 \cdot 01$ & & & & \\
\hline $\operatorname{Mg} O$ & $=$ & $9 \cdot 47$ & $4 \cdot 89$ & $1 \cdot 43$ & 0.50 & $1 \cdot 26$ & $0 \cdot 26$ & $0 \cdot 16$ \\
\hline $\mathrm{Na}_{2} \mathrm{O}$ & $=$ & $3 \cdot 27$ & $4 \cdot 60$ & $8 \cdot 83$ & $7 \cdot 75$ & $7 \cdot 3: 3$ & $8 \cdot 82$ & $9 \cdot 87$ \\
\hline $\mathrm{K}_{2} \mathrm{O}$ & $=$ & $1 \cdot 80$ & $2 \cdot 17$ & $4 \cdot 86$ & $3 \cdot 67$ & $3 \cdot 91$ & $5 \cdot 96$ & 4.98 \\
\hline $\mathrm{P}_{2} \mathrm{O}_{5}$ & $=$ & $0 \cdot 40$ & $0 \cdot 67$ & $0 \cdot 0.3$ & $0 \cdot 12$ & $0 \cdot 38$ & $0 \cdot 07$ & trace. \\
\hline $\mathrm{Cl}$ & $=$ & & & & & $0 \cdot 17$ & & \\
\hline $\mathrm{H}_{2} \mathrm{O}$ at $110^{\circ}$ & $=$ & $0 \cdot 12$ & $0 \cdot 66$ & $0 \cdot 0.8$ & $0 \cdot 10$ & $0 \cdot 19$ & 0.28 & $0 \cdot 08$ \\
\hline \multirow[t]{2}{*}{$\mathrm{H}_{2} \mathrm{O}$ above $110^{\circ}$} & $=$ & $0 \cdot 16$ & $0 \cdot 11$ & $0 \cdot 12$ & $(0 \cdot 19$ & $11 \cdot 39$ & $(1 \cdot 33$ & $0 \cdot 85$ \\
\hline & & $100 \cdot 26$ & $100 \cdot 57$ & $100 \cdot 46$ & $100 \cdot 24$ & $100 \cdot 45$ & $100 \cdot 76$ & $100 \cdot 80$ \\
\hline
\end{tabular}

* For discussion of analyses see below.

† Beeke, 1.c., p. 177.

‡ Saner, Untersuch. ü. phonolit. Gesteine der Canarischen Inseln, Inaug. Diss., IIalle, 1876, p. 60.

$\$$ The analysis of the glassy limburgite 326 is here omitted, sinee the result is almost identieal with that of the holoerystalline olivine-basalt 656 . 


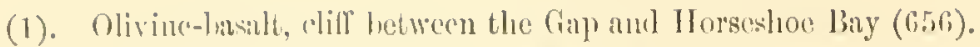

(乡). Il mrublende-basatt, cone below (astle Hill (38s5).

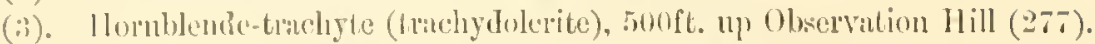

(1). Phonolitic trachyte (1 rachydolerite), Seott Island.

(5). Lancite-kenyte, "Kép" of Cipe Royds, slope of Momt limebus (818).

(ii). P'honolitic trachyte, top of 9oo-ft. Knoll, Momnt 'Temor (188).

(7). I'honolitie tiacliyte, crater of Brown Istand (607).

As an experiment in the nse of the American quantitative system of "litssification the "norms" (pereentage nineral composition hy weight) of the seven roeks were calculated, and are given in the following talble:-

\begin{tabular}{|c|c|c|c|c|c|c|c|c|}
\hline & & (1) & $(2)$ & (3) & $(t)$ & (5) & (6) & (7) \\
\hline 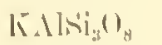 & $=$ & $10 \cdot 5.5$ & $12 \cdot 73$ & $28 \cdot 95$ & $21 \cdot 76$ & $2: 2 \cdot 92$ & $85 \cdot 60$ & $29 \cdot 17$ \\
\hline $\mathrm{N}: 11 \mathrm{Ni}_{3} \mathrm{O}_{8}$ & $=$ & $4 \cdot 19$ & $12 \cdot 0.5$ & $2 ! 1 \cdot 30$ & $35 \cdot 24$ & $11 \cdot 17$ & $: 1 \cdot 82$ & :89) 980 \\
\hline 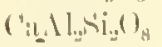 & $=$ & 2015.57 & $20 \cdot 2 ! 9$ & $1 \cdot 69$ & $7 \cdot 81$ & $1: 2 \cdot: 3$ & $(1.77$ & $2 \cdot 50$ \\
\hline Ninlisio, & $=$ & $12 \cdot 78$ & $1.1 \cdot 18$ & $21 \cdot 56$ & $16 \cdot 5.3$ & $11 \cdot 07$ & $18 \cdot 72$ & $28 \cdot 60$ \\
\hline Nil Fesion. & $=$ & & & $1 \cdot 88$ & & & $1 \cdot 58$ & \\
\hline$(\mathrm{asiO}$ & $=$ & $11 \cdot 71$ & $9 \cdot 51$ & $5 \cdot 23$ & $: \because \cdot 71$ & 0.16 & $:) \cdot(i)$ & $1 \cdot 102$ \\
\hline Fingo & $=$ & $2 \cdot 51$ & $2 \cdot 90$ & & $9 \cdot: 87$ & $0 \cdot 3,9$ & & $0 \cdot 7 ! 1$ \\
\hline $\mathrm{M}_{\text {intill }}$ & $=$ & $8 \cdot 20$ & $1 ; \cdot 00$ & $\because \cdot \cdot 1 j 0$ & $1 \cdot 311$ & $0 \cdot 30$ & $11 \cdot 66$ & $0 \cdot 10$ \\
\hline lenillo. & $=$ & $3 \cdot 187$ & $2 \cdot 3.1$ & & & $3 \cdot 67$ & & \\
\hline $\mathrm{MH}_{2} \mathrm{NiO}_{4}$ & $=$ & $10 \cdot 78$ & $1 \cdot 27$ & & & $1 \cdot 96$ & & \\
\hline $\operatorname{lic}(0) \cdot \operatorname{lig}()_{3}$ & $=$ & $1 \cdot 17$ & $6 \cdot 03$ & $2 \cdot 25$ & $2 \cdot 5 i$ & $2 \cdot 32$ & $\because \cdot 41$ & $1 \cdot: 3$ \\
\hline l'on-l'io., & $=$ & $9 \cdot 27$ & $7 \cdot 90$ & $2 \cdot 51$ & $1 \cdot 2 \cdot 2$ & $2 \cdot 28$ & 0.77 & $0 \cdot 16$ \\
\hline$\left({ }^{1}: 1 ; 2 \geq l^{\prime}()_{1}\right.$ & $=$ & $(1 \cdot 9: 3)$ & $1 \cdot \ldots$ & $0 \cdot 20$ & $0 \cdot 31$ & $01 \cdot ! 3 ;$ & & \\
\hline
\end{tabular}

'The lames which the rocks would receive in this new elissification are as follows:-
(1) limburgose.
(2) limburgose.
(i) Latimdalose.
(1) Essexose.
(5) Tamvikose.
(i) Mirskose.
(i) Minskose.

The result shows that the classifiention supplies a varicty of names to rocks not differing very wielely in ehemical composition.

Inother system for the chemical classifieation of igneons roeks, which has lecen recently lnomght forwind, is that of Osamn. $\dagger$

This classifiention is bised on the molecular pereentages as ealenlated from the resultis of antlysis. For the seven antyses the moleculat pereentages are as follows:-

\begin{tabular}{|c|c|c|c|c|c|c|c|c|}
\hline & & (1) & (2) & (3) & (1) & (5) & (C) & (7) \\
\hline sio. & $=$ & $15 \cdot 06$ & $48 \cdot 92$ & $(i 2 \cdot 78$ & $(63 \cdot 17$ & $63 \cdot 66$ & $60 \cdot 19$ & $6,6 \cdot 9 \cdot 2$ \\
\hline I'i(i) & $=$ & : & $3 \cdot 52$ & $1 \cdot 13$ & $0 \cdot 51$ & $1 \cdot 115$ & (1).35 & \\
\hline$\left.\Delta\right|_{.2}()_{3}$ & $=$ & $1 \cdot 14$ & $11 \cdot 16$ & $1: 3 \cdot \$ 1$ & $13 \cdot 11$ & $1: 3 \cdot 94$ & $13 \cdot 85$ & 15. \\
\hline licen & $=$ & $1 \cdot 17$ & $1 \cdot 7 !$ & $1 \cdot 21$ & $(1 \cdot 75)$ & $0 \cdot$ rili & $1 \cdot 1 !)$ & (1). \\
\hline le(t) & $=$ & $\therefore \cdot 7 ; 3$ & $8 \cdot 27$ & $1 \cdot 7 !$ & $(i \cdot 12$ & $3 \cdot 71$ & $1 \cdot 3:$ & \\
\hline ('it) & $=$ & 11.87 & $11 \cdot[2$ & $.1 \cdot 18$ & $1 \cdot 2 !)$ & $: 3 \cdot 89$ & $2 \cdot 3.1$ & \\
\hline $11 \lg$ & $=$ & $15 \cdot 15$ & $s \cdot 1$. & $2 \cdot 12$ & $0 \cdot 81$ & $2 \cdot 11$ & $(1 \cdot 1 \pi)$ & $0 \cdot$ \\
\hline$N_{i 1}()$ & $=$ & $: ; \cdot 111$ & $1 \cdot ! ! !)$ & $9 \cdot 17$ & $8 \cdot 5 \cdot 2$ & $s \cdot 0 ! 9$ & היהשי (1) & $1111^{\prime}$ \\
\hline (1.1) & $=$ & 1.2.2 & $1 \cdot 5.5$ & : & $\approx$ - liti & $2 \cdot 81$ & $4 \cdot 34$ & $\ddot{Z} \cdot 1$ \\
\hline
\end{tabular}

* (Quntitutivo Chassiticntion of lyneons liocks, Cross, Mdings, lirsson and Washington, Chiengo, 1903,

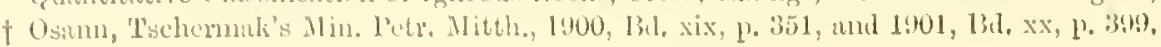




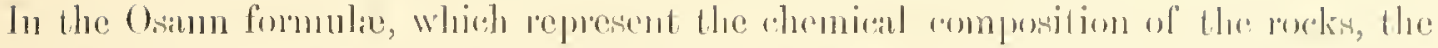

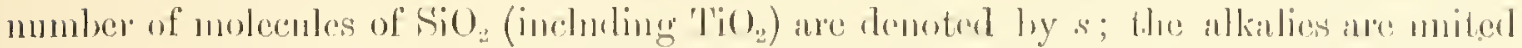
to $\mathrm{Al}_{2} \mathrm{O}_{3}$ (ats in the felspars and felspathojds) in a group (Nali) $\mathrm{Al}_{2} \mathrm{O}_{4}$, which is domoted.

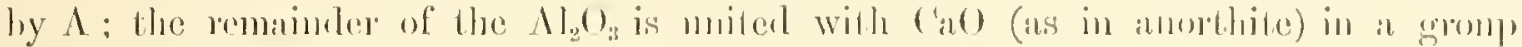

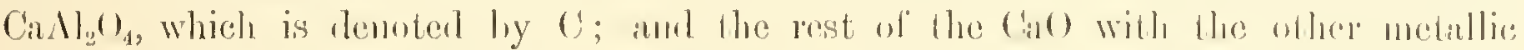

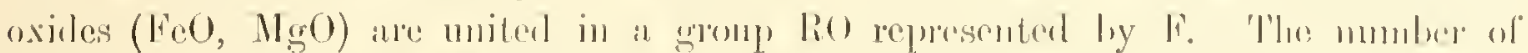

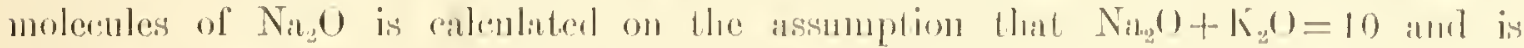

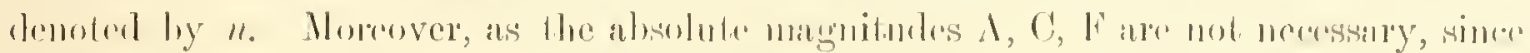

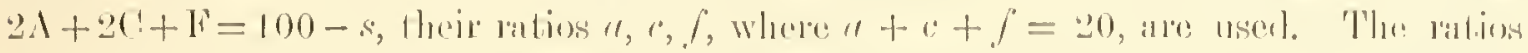

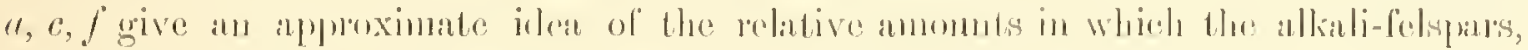
anorthite and dark constitnents, enter into the compusilion of the rocks.

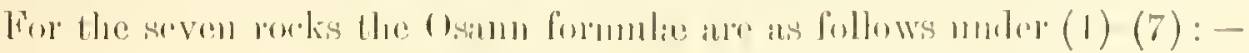

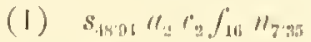

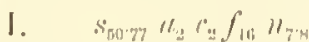

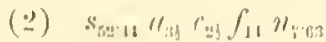

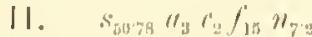

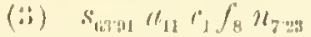

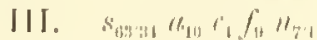

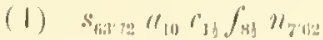

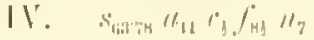

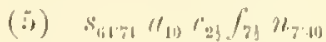

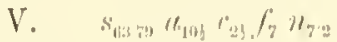

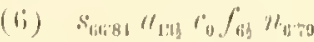

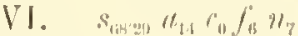

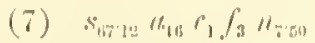

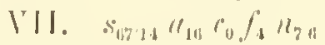

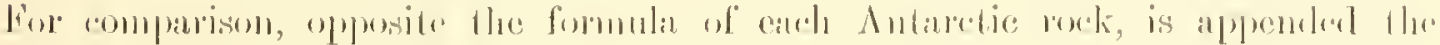
formula (I-VII) of the followiog :-

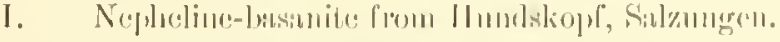

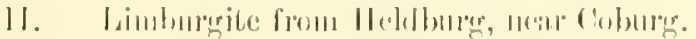

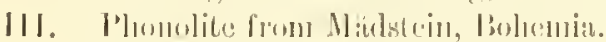

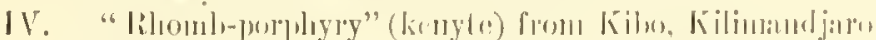

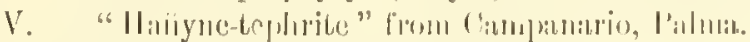

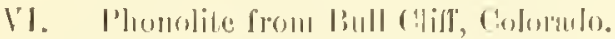
IJI. I'lonolibe from Mous Mianne, Veliny.

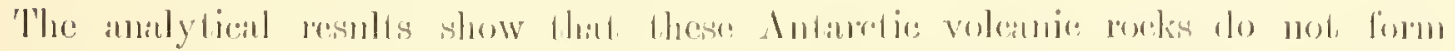

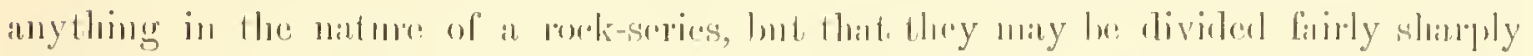

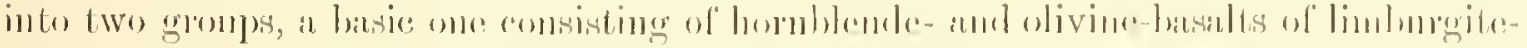

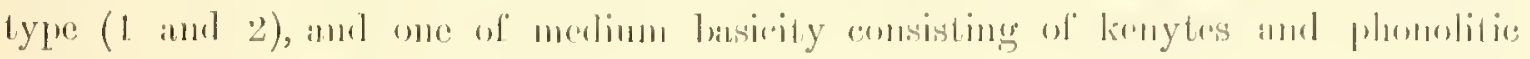
trachytes $(3-7)$ very rivh in allkalies.

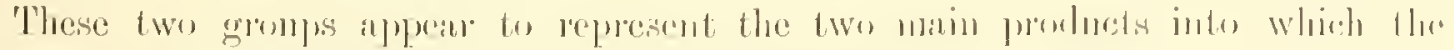

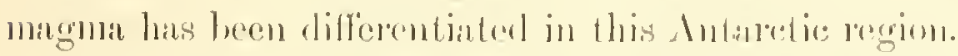

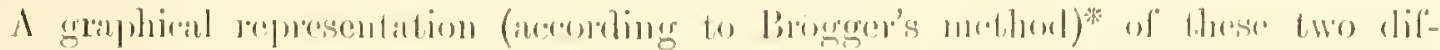

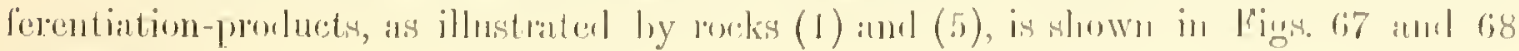
lespectively.

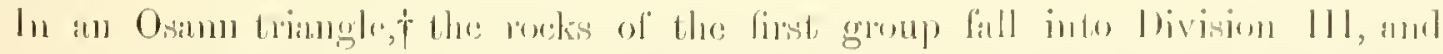

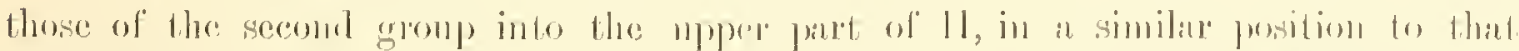

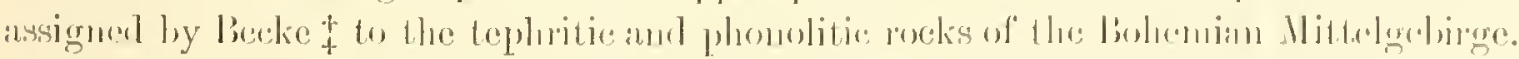

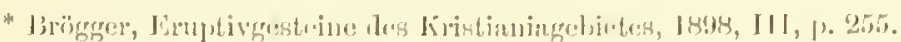

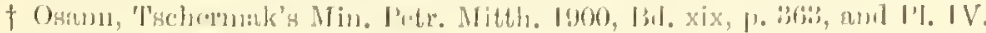

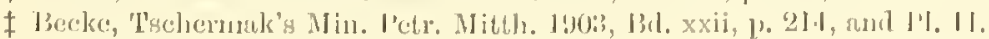


In both the basaltie and alkaline groups, the ratio of soda to potash is nearly the same, with $\mathrm{T}_{\mathrm{a}}>\mathrm{K}$. A similar hasaltie hornblende occurs in certain rocks of each group, and not in others in which its place is taken by olivine. The presenee or alsence of homblende in both groups probably depended to a large extent upon the conditions of eruption; in the dylie-rocks, which eooled while still under a high pressure, the mineral was more likely to survive than in the lavas.

Ntogether, this Antarctic region, from Scott Island in the north to the Minna Bhuff in the south, has good daim to le regarded as a definite petrographical province

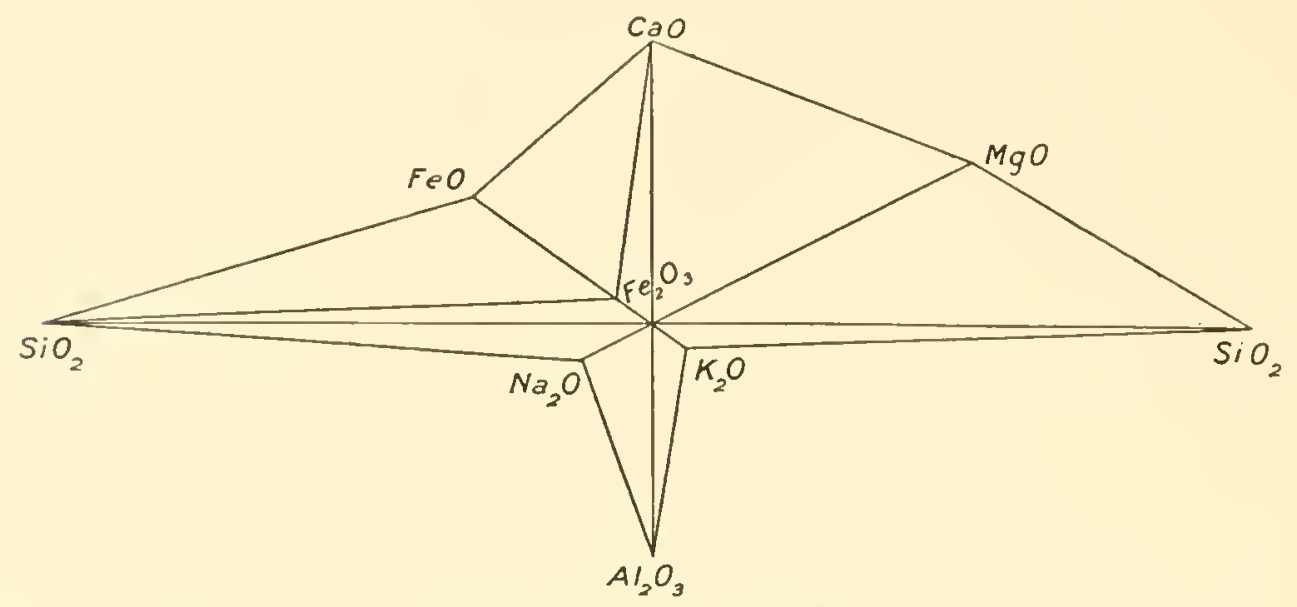

Fig. 67.-Graphical Representation of the Cinemical Composition of tile Olivine-Basalt (656) from near the Gap.

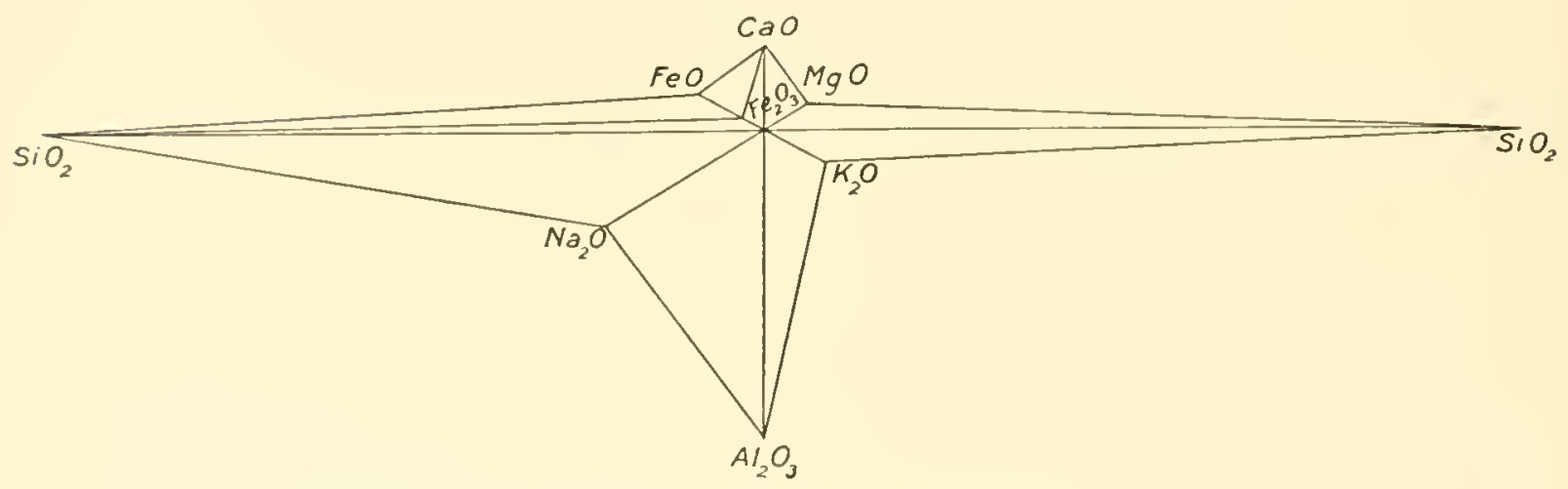

lig. 68.-Grapincal Representation of the Chemical Composition of tile LEUCiTE-KENYTE (818) FROM CAPE RoYds.

characterised by the association of basalts of limburgite-type with alkali-rieh rocks of medium basicity in which anorthockase is the prevailing felspar.

In a whler sense, these Antarctic roeks belong undoubtedly to the great Atlantic as olposed to the Parific type of eruption. The marked contrast between the younger volcanic rocks of the Athantic volcanic chain and its lateral branches, and those of the volunoes cucireling the l'acifice Ocean, was pointed out by the author anongst the conclusions drawn from a study of the igneous rocks of the Great lift Valley of East 
Africa.* In the same year similar ideas were brought forward with greater elaboration by Becke in a striking contrast which he drew between the volcanic rocks of the Bohemian Mittelgelirge and those of the Audes. $\uparrow$ He suggested that these two Pacific and Atlantic types were intimately connected with the two tectonic processes of Suess which have mainly affected the earth's crust, viz., faulting by tangential pressure, and fracture by radial contraction; where young volcanic rocks occur along a faulted mountain-chain like the Andes, they belong to the Pacific group; where, on the other hand, they oceur on block-fractures ("Schollenbriche"), they belong to the Atlantic type.

In the case of these Antarctic eruptions, we have voleanic rocks of undoubtedly Atlantic type developed along a coast which las been described as typically Pacific. 'They form, thercfore, apparently an exception to Becke's rule; but it may be pointed out that the volcanocs of South Victoria Land, from which specimens of lava have been obtained, are not gencrally ranged parallel to the coast, but appear to occur along lines of weakness directed ncarly at right angles to it.\$

As regards the relative ages of the basalts and alkali-rich rocks of the Ross Archipelago, the observations in the field lead to no very conclusive result. From the intrusive appearance of the trachyte on the south-east end of Black Island (see p. 14), Mr. Ferrar was inclined to regard the trachytes as younger than the hasalts, but he was unable to examine closely the actual junction of the two rocks at this spot. In the case of the kenytes of Mount Erebus and the islands in Erelus Bay, Mr. Ferrar is of opinion that they are older than the basalt-flows of Winter Quarter's, since on Razor Back Island thcy arc bent into a sharp anticline which has not affecterl the other rocks. It seems probable, therefore, that the trachytic rocks having a chenical composition so similar to that of the kenytes are also older than the basalts. This idea is also supported by the fact that the bombs scattered over trachytic rocks are of the same character as the basalts. Mr. Ferrar also describes the trachyte-hosses (e.\%., that exposed in the Gap) as oceurring like "islands," without off-shoots into the basalt. Thus Observation Hill is probably not intrusive in the hasalts, but stands out from them as an older rock, just as the phonolite-peak of Fermando Noronha projects above the younger basalts.

On the whole, therefore, it secms probable that in these Antaretic volcanic rocks the sequence of eruption has been from rocks of medium basicity to basic, and that the trachytes and kenytes preceded the basalts.

* Prior, Contributions to the Petrolog. of British East Africa, etc., Nineralogical Magazine, 1903, rol. xiii, p. 260.

† Becke, Tschermak's Min. Petr. Mitth. 1903, Bd. xxii, p. 248.

$\ddagger$ Gregory, Nature, 1906, rol. Ixxiii, p. 300.

$\S$ See, howcrer, footnote on p. 140. 
CHAPTER II.

\section{TIE BASEMENT-ROCKS OF SOUTII VICTORIA LANI).}

\section{Cristallane Linestone.}

'The erystalline limestones, which appenr to constitute the prevailing rock of the Northern and Southern Foothills, are coarse-grained aggregates of ealcite-crystals loosely held together. For the most part they are very pure, and show, in addition to the ealcite, only a few small flakes of graphite and of a nearly-colourless phlogopite. Amongst the specimens, lowever, which were found by Dr. Wilson along Discovery Gulf, are fragments of crystalline limestone containing numerous rounded yellow erystals, which analysis has shown to be of chondroulite. The rock (see Fig. 69) is very similar in appearance to the chondrodite-linestones of Burma and Finland.

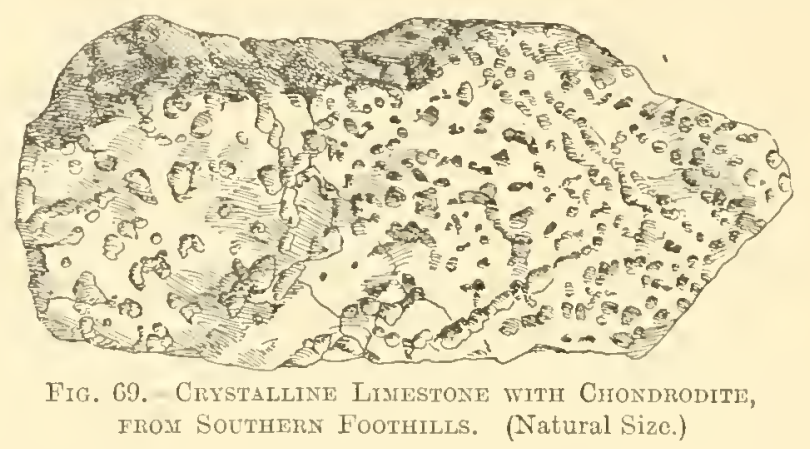

Amongst the boulders found on the East of Mount Terror, just above the Barrier, is one of a schistose erystalline limestone, or calc-schist, containing quartz in fine grains in alternating bands with the calcite.

\section{GNEISS.}

Of gneisses there are not many specimens in the collection. 'They are gray and red foliated medium-grained roeks, some of which show conspicuous augen-strueture. Like the Arctic gneisses of Greenland* these Antaretic rocks have the charaeters of metanorphosed granites and diorites (orthogneiss). They eonsist of orthoclase, oligoclase, quartz, biotite, and almost invariably homblende. Niurocline was not detected in any of the gneisses examined, but it ocems in large plates in a felspatlice grit on Finger Mountain, which had obviously been derived from the decomposition of gneissic and granitic rocks.

In the augen-gneiss, orthoclase generally forms the "eyes" which enclose biotite, idiomorphic oligoclase, and occasionally rounded blebs of quartz. $\dagger$ The "eyes" are mostly altered and red with oxile of iron. 'They are enclosed in a mosaie consisting of

* Belowsliy, Jicit. z. Petrog. west. Nord-Grönlands, Zeit. d. deut. geol. Ges., 1905, I3d. Ivii, pp. 15-90.

† Lrans, Quart. Joum. Geol. Soc, 1906, rol. 1xii, p. 96. 
interlocking grains of clear quartz and slightly altered oligoclase and orthoclase, with biotite and lornblende in strings marking the foliation. Both quartz and orthoclase in the mosaic oecur in very irregular interpenetrating patches, which in ordinary light appear to belong to individual crystals, but break up between crossed nicols into a number of differently orientater grains. Cataclastic strueture of this kind is well marked in the augen-gneiss 722 (see Plate IX, Fig. 1) from $\mathrm{D}_{4}$ in the Kukri Hills (pp. 30 and 38). In this roek the interspaces between the large "eyes" of orthuclase are oceupied partly loy a quartz-mosaic slowing marked undulose extinetions, and partly by shattered felspars crowded with small blebs of quartz ("quertz de composion," as deseribed loy Lacroix in the case of the charnockites of India*), or forming with quartz a micropegmatitic intergrowth (see Fig. 70).

The red augen-gneiss (716) from Cathedral Rocks has somewhat similar characters, but the quartz-felspar-mosaic between the large "eyes" of pink orthochase shows less pronounced cataclastic structure, and the quartz and felspar are in more distinct grains; effects of pressure, however, are evident in the bent twin-lamelle of the oligoclase, and quartz of corrosion is also present. This red granite-gneiss appears to be intrusive in the gray, just as in Greenland the fine-grained red gneisses are intrusive in the gray mica- and hornblende-gneisses.

From Cathedral Rocks comes a hornblende- or diorite-gneiss (724) consisting of a granular aggregate of quartz and plagioclastic felspar with much pleochroic (green to brownish-yellow) hornblende. The

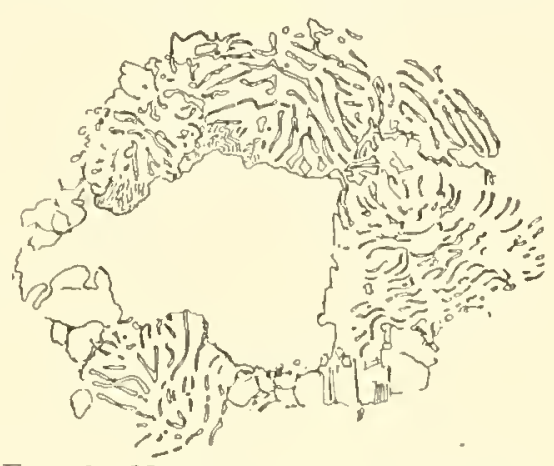

FIG. 70.-MICropegnatite SURRounding Fetspar IN ACGEN-GNEISS (727) FROM THE KuKRI Hills. (Magnification, 25 dian.) quartz is not in large amount, and the felspar is more basic than the oligoclase of the other gneisses, since it shows symmetrieal extinctions of $18^{\circ}-21^{\circ}$.

Associated with the gneisses are hornblende-schists $(730,704)$ which help to give the dark streaky appearance to the rocks referred to on p. 28.

\section{Granites and Dionites.}

The granites of South Victoria Land are for the most part typical hornblendebiotite-granites similar to those from Cape Adare brought back by the 'Souther'n Cross' Expedition.

Of these rocks the more noteworthy will be considered under the partienlar localities from which they come, and as far as possible in the order in which they are mentioned in the Report on the Field-geology.

Granite Hurbour.-The gray biotite-granite (129) which forms the greater part of the boss at Granite Harbour (see p. 33) is somewhat gneissie in character, and shows signs of parallel structure in the arrangement of the shreds of biotite. It consists of

\footnotetext{
* Lacroix, Rec. Geol. Surv, Ind., 1891, vol. xxiv, p. 168.
} 
large plates of orthorlase and oligoclase, with interstitial quartz-mosaic (cataclastic structure) and flakes of biotite. The oligoclase is mostly illiomorphic, and shows hoth allite- and pericline-twimning. A little sphene and small rounded zircons are present as accessory mincrals. The rock shows evidence of pressure in the strain-shadows in the quartz, as well as in slight bending of the twin lamella and fracture of the erystals of oligoclase. The dyke-rock (155), except for the large porphyritic red felspars, is similar to 129 , and also shows parallel strueture in the arrangement of the biotite-flakes, tout the quartz-mosaic is of coarser grain. The large porphyritic orthoclases enclose rounded erystals of olignelase.

Other veins in the gray granite are of quartz-porphyry, and are doubtless apophyses of the granite (155), since they show similar large red porphyritic crystals of orthoclase and oligoclase. In specimen 168 these phenocrysts oceur with large rounded quartz-crystals and small pleochroie (grass-green to yellow) hornblendes in a cryptoerystalline felsitic hase.

The rock-specimens collected from the scree-slopes in Granite Harbour include :augen-gneiss; epidosite; granites with large red porphyritic felspars; pegmatite; rery beautiful quartz-porphyries, showing large pink porplryritic felspars and rounder quartz in a fine-grained felsitie base; diorites with large porphyritic hornhlendes, somewhat similar to the dyke-rock (715) from Cathedral Rocks described below; sandstones and dolerites (see p. 138), preciscly similar to those of the Ferrar Glacier; and also gabbros, showing under the mieroseope lauge ophitic plites of colourless augite and green uralitic homblende in a coarse-grained aggregate of plagioctastic felspars with much plenchroie (colourless to rose-red) sphene.

The Smithem Foothills.-The gray rock (569) from the Southern Foothills, which occurs in hands parallel to the joint-planes of the erystalline limestone (see p. 25), consists of a medimm-grained allotriomorphic aggregate of oligoclase, ortloclase and qunrtz, with shreils of green to lorown homblende and biotite showing well-marked parallel strueture. Grains of honey-yollow sphene are very alumbint.

The Smor Villey. Of the granites from the Snow Valley between Catherlial Rorks and the Northern Fonthills (p. 33), the porphyritic ruck (563) from $c_{6}$ is the most noterortly. It shows large porphyritic pink crystals of orthoclase, around which lines of small hornhlende-erystals appear to flow. Under the mieroseope the groundmass is seen to consist of allotriomorphic oligoclase and orthochase and pleochroic (yellowish-hown to black) homblende, with quartz in quite subordinate amount. The roarse-gramed porphyritic granite (55.5) from the knoll $e_{5}$ shows fairly idiomorphie oligodase and less sharply defined orthorlise embayed by quartz, which has been olviously the last mineral to consolidate; homblente and hiotite are not in large amount: some sphene is present. $\Lambda$ dark pateh in this granite has the composition of "hasic diorite or essexite somewhat like the rork of the "tongue" (715) described on the next page. It consists of a coarse-grained aggregate of plates of altered plagioclase, large ophitic reddish-lorown hornblende and colourless diopside. 
Cathedral Rochs. - Of the specimens from Cathedral Rocks, the rock 715 of the 'tongue' or 'pipe' east of the shoulder Ez presents noteworthy features and has the charaeters of a basie diorite or homblende-gabbro. It consists (Plate IX, Fig. 2 ) of fairly idionorphie erystals of labradorite, showing symmetrical extinetions of about $22^{\circ}$, and large ophitie plates of hornblende, with interstitial quartz in yuite subordinate amomnt. The hornhlende has pleochroism from brownish-yellow to deep reddish-brown like that of barkevilite, but the extinction in some crystals is as high as $15^{\circ}$; it encloses small altered felspars and much apatite. The section shows also two plates of hypersthene, one enclosed in homblende and the other altering to fibrous actinolite; it gives straight extinetion and is faintly pleochroic, from pale-green for viluations along the length to pale-pink for those across. Other specimens ( 712 and 721$)$ from the same 'tongue' show similar ophitic plates of hornblende, but contain also some biotite and orthoclase and much more quartz. They approach, therefore, more closely to hornblende-granites. The homblende, too, in these specimens is of somewhat different eomposition, showing pleochroism from dark-green to brown. Prisms of allanite oceur in these rocks and apatite is very plentiful.

A chemical analysis of specimen 7 I5 gave the following result under I :-

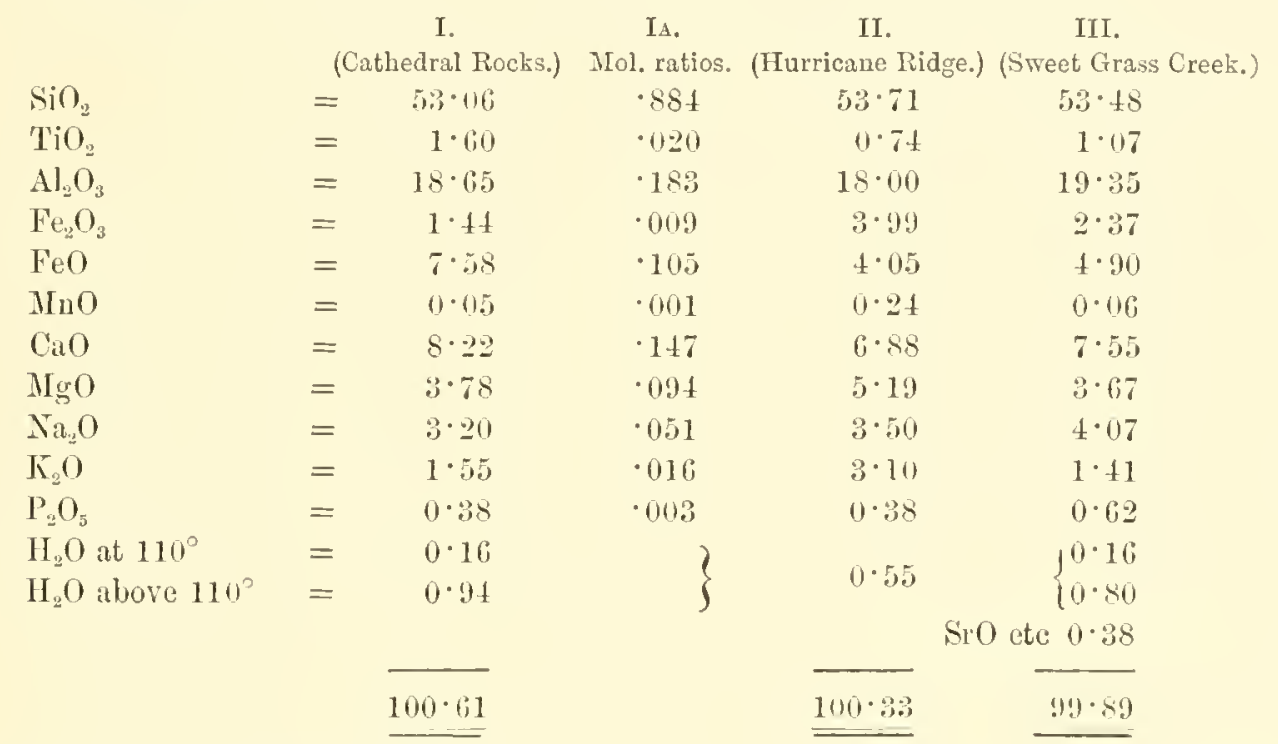

The Osann formula of this rock is :-

which is between that of Usann's Hurrieane Ridge type:-

and his Sweet Grass type:-

$$
\begin{aligned}
& s_{58: 95} a_{4} c_{4} f_{122} n_{6 \cdot 3} \\
& s_{6005} a_{4} c_{5 !} f_{101} n_{8 \cdot 1} .
\end{aligned}
$$

The analysis of the mica-gabbro from IInrricane Ridge, Yellowstone National Park, is given under II,* and that of the quartz-diorite from Sweet Grass Creek, Crazy Mountains, under III.†

\footnotetext{
* Tddings, Monogr. U.S. Geol. Surv., 1899, No. 32, Part II, p. 340.

$\dagger$ Clarke, Bull. U.S. Geol. Surv., 1897, No. 148, p. 143.
} 
Cilculation of the "norm" gave the following result:-

$\begin{array}{llr}\mathrm{KAlNi}_{3} \mathrm{O}_{8} & = & 8 \cdot 90 \\ \mathrm{NaAlSi}_{3} \mathrm{O}_{8} & = & 26.72 \\ \mathrm{CaAl}_{2} \mathrm{Si}_{2} \mathrm{O}_{8} & = & 332.25 \\ \mathrm{SiO}_{2} & = & 3.48 \\ \mathrm{CaSiO}_{3} & = & 2.55 \\ \mathrm{FeSiO}_{3} & = & 10.03 \\ \mathrm{MgSiO}_{3} & = & 9 \cdot 40 \\ \mathrm{FeO} . \mathrm{Fe}_{2} \mathrm{O}_{3} & = & 2.09 \\ \mathrm{FeO}_{2} \mathrm{TiO}_{2} & = & 3.04 \\ \mathrm{Ca}_{3} 2 \mathrm{PO}_{4} & = & 0.93\end{array}$

In the American quantitative system the rock would be elassed as Ifessuse.

Blue Glucier. - Of somewhat similar chararter to the rock of the "tongue" are the dyke-rocks (572-574) collected by Dr. Koettlitz half-way down the Blne Glacier. Ine of these, in whieh the hornblende ocurs in large ophitic plates, is almost identical with the rock of the "tongue," but the others are less coarse-grained, and show more numerous and better arystallised phenocrysts of hornhlende. In this respect they resemble camptonitic rocks from IIontreal, but are of coarser grain and approarh to essexites. Under the microseope (Plate IX, Fig. 3), they show long, prismatic erystals of hornblende in liurge amount, with interstitial plates of altered felspar; hexagonal sections of apatite are very plentiful, while grains of magnetite and ilmenite occur very sparingly. The homblende is similar to that in the "tongue" with pleochroism : $\alpha=$ brownish-yellow, $\beta$ and $\gamma=$ deep reddish-brown, and extinction as high as $15^{\circ}$; most of the sections show a dark-green margin.

Kulki IIills.-The specimens $(699,700)$ from the Kukri ILills, illustrating the intrusion of granite into dolerite (see p. 36), show pink granite in contact with and alnost surrounding fragments of a dark-gray rock. Under the mirroseope the latter is seen to consist of felspar, in interlocking grains and indistinct prisms, with shreds and irregular patches of green hornblende and a little quartz. Aecessory constituents are one or two small erystals of sphene and a few shreds of chlorite enclosing magnetite. The hormblende shows pleochroism: $a=$ pale yellowish-brown, $\beta=$ dark greenishbrown, $\gamma=$ dull green. If this rock, therefore, represents a dolerite like those deseribed in a later section (p. 136), it has suffered as extreme a metamorphism as some of the old dolerites of Cornwall.

Anongst the pebbles from the dredge off King Edward VII Land are hornblende-biotite-granites and gneisses, and diorites with large ophitic plates of hornblende. One pehble of coarse-grained biotite-granite differs from the other's in containing large crystals of mierocline.

A boukler of horublende-biotite-granite from the 500-ft. slope on Mount 'Terror' deserves mention owing to the peculiar character of the hiotite, which oeeurs in small thick crystals standing out conspieuously from the white gromind-mass. 
Chapter 1II.

\section{DYKE-ROCKS (LAMPROPHYRES, ETC.).}

The dyke-rockis in the erystalline limestones and granites form an interesting series ranging from kersantites to rocks allied to the banakites of Wyoming. Some of the dykes show numerous phenocrysts of basaltic hornblende and approach to camptonites such as occur generally in association with nephelinc-syenites. No speeimens, however, of the latter rocks appear to have been met with in this Antarctie region.

\section{Camptonites.}

A typical camptonite is the dark-gray rock (839) found in situ by Dr. Wilson at the south end of the Southern Foothills, near the Koettlitz Glacier. To the naked eye this rock shows only a few small phenocrysts of hormblende. Under the microscope (see Plate IX, Fig. 5) the rock is seen to eonsist of small prismatie crystals of reldishbrown hornblende thickly distributed in a base of lath-shaped felspars with a little quartz. The hornblende has the same optical charaeters as that in the diorite described above (p. 127). The felspar-laths are of labradorite with refraetion markedly greater than that of Canada balsam, and symmetrical extinetions as high as $19^{\circ}$. Nagnetite and ilmenite are virtually absent. The section shows one or two foreign enclosures of quartz containing liquid-inclusions with bubbles.

To the camptonites must also be referred a specimen (629) brought by Lieut. Armitage from the foot of Cathedral Roeks. It is a dark greenish-gray rock showing to the naked eye no porphyritic crystals. Under the mieroscope small green uralitie hormblendes are seen in a base of felspar-laths and thickly-distributed ragged prisms and minute needle-like microlites of basaltic hornblende with a little biotite. The felepar-laths appcar to be of oligoclase: one rhombic seetion eut nearly parallel to b (010) gave a positive extinction of about $10^{\circ}$. The hornblende-prisms show wellmarked flow-structure.

A specimen (498) from a moraine at New Harbour Height (S. foot) shows the junction of a gray hornblende-biotite-granite and a black fine-grained camptonitic rock. The latter consists of numerous small sharply-defined prismatic erystals of basaltic hornblende, in a base showing a few fclspar-laths and a little quartz but rendered dense with long hornblende-mierolites. Besides the hornblendes a few prismatic erystals of colourless augite are also present. None of the small phenocrysts exceed $0.3 \mathrm{~mm}$. in length. Near the junction the base becomes more dense and glassy and shows no well-defined hornblende-microlites. 


\section{KERSATTTES.}

The twenty-yards-wide dyke (579) cutting the "rystalline limestone at $\mathrm{G}_{1}$ in the Northen Foothills (spe p. 27) is an angite-biotite-kersantite. It is a speckled gray rock showing to the naked eye numerous flakes of hiotite. Under the mieroscope irregular pale-green to pale-purple augites and much biotite in shreds and straggling ophitic patches are seen in a medium-grained mesh of plagioclase-laths with a little interstitial quartz (see Plate IX, Fig. 4). A little reddish-hrown hornblende of the same dhaneter as in the preceding rocks is also present. The felspars are altered and kaolinised; some with refraction less than that of Canada balsam are doubtless orthoelase, lut most have higher refraction and are probably oligorlase.

A chemical analysis of this rock gave the following result under I. For comparison is appended, under II, an analysis of a kersantite from Stengerts, Spessart, ${ }^{*}$ and under III that of a shoshonite from Beaverdam Creek, Yellowstone Park.†

\begin{tabular}{|c|c|c|c|c|c|}
\hline & (North & I. & $\begin{array}{l}\text { 1A. } \\
\text { Mol. ratios. }\end{array}$ & $\begin{array}{c}\text { II. } \\
\text { (Stengerts.) }\end{array}$ & $\begin{array}{c}\text { III. } \\
\text { (Beaverdam Creck.) }\end{array}$ \\
\hline $\mathrm{SiO}_{2}$ & $=$ & $50 \cdot 71$ & $\cdot 810$ & $51 \cdot 81$ & $5 i 3 \cdot 4 !$ \\
\hline 'T'iO, & $=$ & $2 \cdot 71$ & $\cdot 0: 3$ & & $0 \cdot \pi I$ \\
\hline $\mathrm{Al}_{2} \mathrm{O}_{3}$ & $=$ & $17 \cdot 08$ & $\cdot 167$ & $16 \cdot 6.5$ & $17 \cdot 19$ \\
\hline $\mathrm{Fe}_{2} \mathrm{O}_{3}$ & $=$ & 1.38 & $\cdot 0009$ & $4 \cdot 933$ & $1 \cdot 7: 3$ \\
\hline lico & $=$ & $8 \cdot 71$ & 122 & $\because 11$ & $: 3 \cdot 05$ \\
\hline $\mathrm{H}_{11 \mathrm{O}}$ & $=$ & $0 \cdot 09$ & & $0 \cdot 29$ & $(1) \cdot 1.4$ \\
\hline$(\mathrm{ibO}$ & $=$ & $5 \cdot 75$ & $\cdot 102$ & $7 \cdot 35$ & $6 \cdot 3 t$ \\
\hline $\operatorname{MIg}()$ & $=$ & $8 \cdot 63$ & $\cdot 090$ & $6 \cdot 90$ & 1.40 \\
\hline $\mathrm{N}_{\mathrm{r}_{2} \mathrm{~g}_{2}}$ & $=$ & $3 \cdot 82$ & $\cdot 061$ & $: 3 \cdot 6$ & $3 \cdot 2 ! 3$ \\
\hline $\mathrm{K}_{2} \mathrm{O}$ & $=$ & $8 \cdot 63$ & $\cdot 0187$ & $1 \cdot 05$ & $\because: \&$ \\
\hline $\mathrm{P}_{2} \mathrm{O}_{5}$ & $=$ & $0 \cdot 57$ & $\cdot 00.4$ & & $0 \cdot 4: 3$ \\
\hline $\mathrm{H}_{2} \mathrm{O}$ at $110^{\circ}$ & $=$ & $0 \cdot 16$ & & 1.32 & $\because \cdot 17$ \\
\hline $11_{2} \mathrm{O}$ above $110^{\circ}$ & $=$ & $1 \cdot 75$ & & & \\
\hline \multirow[t]{2}{*}{$\mathrm{CO}_{2}$} & $=$ & trace & & $0 \cdot 50$ & $\operatorname{IBa} O=0.06$ \\
\hline & & $\$ 9 ! 999$ & & $99 \cdot 61$ & $1(10) \cdot(1)=$ \\
\hline
\end{tabular}

'The () simn formulat of this lock is :--

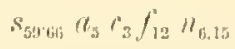

which is near that of the shoshonite from Beaverdam (1'reek:-

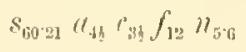

\begin{tabular}{|c|c|c|}
\hline$K \backslash 1 \mathrm{Si}_{3} \mathrm{O}_{8}$ & $=$ & $20 \cdot 57$ \\
\hline $\mathrm{Ni}_{\mathrm{i}} \mathrm{A} / \mathrm{Si}_{3} \mathrm{O}_{8}$ & $=$ & $81 \cdot 96$ \\
\hline $\mathrm{O} \mathrm{CHN}_{2} \mathrm{Si}_{2} \mathrm{O}_{8}$ & & $18 \cdot 6: 3$ \\
\hline $\mathrm{CANiO}_{3}$ & & $2 \cdot 67$ \\
\hline $\mathrm{FeniO}_{3}$ & & $1 \cdot 4 \pi$ \\
\hline $\mathrm{NgSiO}_{3}$ & $=$ & $1 \cdot 20$ \\
\hline
\end{tabular}

(alculation of the " norm" gave the following result:-

* Goller, J)ic Lamprophyrginge des siirlichen Vorspessart. Neues. Jahrb., 1889, Beil.-bul. vi, p. 566.

† Iddings, Geol. of the Yellowstone National Park. Monogr. U. S. Geol. Surv., 1899, No. 32, Part ii, 1. 340. Analysis by Eakins. 


\begin{tabular}{|c|c|}
\hline $\mathrm{Fe}_{2} \mathrm{SiO}_{4}$ & $=$ \\
\hline $\mathrm{Mg}_{2} \mathrm{SiO}_{4}$ & \\
\hline Heo. 'TiO. & \\
\hline $\mathrm{FeO} \cdot \mathrm{Fe}_{2} \mathrm{O}_{3}$ & $=$ \\
\hline$\left(\mathrm{C}_{3} 2 \mathrm{PO} \mathrm{O}_{4}\right.$ & $=$ \\
\hline
\end{tabular}

In the ease of this nicaceous rock the "norm " liverges from the "mode," since much of the potash occur's in liotite and not in orthockase.

In the Americin quintitative system the rock wonlel he diassed ats Shoshomose. 'Thus hoth cheminal systems refer the rock to the sane lype, from which, howerer, it differs somewhat in mineral composition. As a shoshonite it is chenically closely relater to the binakite-like rocks described in the next section.

Another liersintite appears to be the dark-gray dyke (625) intrusive in the gray granite at $\mathrm{E}_{4}$ at a height of ahout 5000 feet. Under the mieroseope it shows long shreals of hiotite and much-altered green hornblende (mostly nralitic after angite, of which a little still remains) in a ground-mass of altered prismatic plagiochatic fielspars.

\section{Dykes Chemionlly Rilated to Banakite.}

Under this hearling are here incheled ertain dyke-rocks which bear some relation to the camptonites in contaning hasiltic homblende as phenocrysts and also occasionally in the ground-1nass, while they difter from them liy the presence of numerous phenoerysts of felspar, some of which are of orthockase.

To this group belongs the hrown dyke (714) in the granite at $G_{3}$ in the Northern Foothills. Besides the large porphyritic erystals of basaltic hormblende referred to on p. 35 it shows also numerous phenocrysts of felspar and it few of augite. 'The felsparphenoerysts are manily of labradorite, with symmetrical extmetions in albite-lamellat of $26^{\circ}$. Others, however, with low refraction and showing no twin-striations are of orthockase, while some with mottled extinctions and refraction abont the sane as that of Canada balsimn are probubly of anorthorlase. A few rounded phenocrysts of anileite are alio present (see I'late IX, Fig. (6).

The ground-mass consists of a holocrystalline mediun-grinined aggregate of plagioclastic: felspars (mainly in rectangular sections, hut also in laths), prismatic crystals of pale-purple augite, and magnetite. Some of the rectangnlar felspars in the ground-mass are of labridorite giving symmetrial extinetions is high as $25^{\circ}$. Apatite-needles are plentiful, and shreds of bown altered hormblendir material are scattered throngh the slide.

A coarse-grained inclusion consists of an aggregate of felspar with refraction near that of Canada balsam, pale-green to purple angite, basaltic hornlslente, and analeite, with large needles of apatite and much magnetite.

A somewhat similar clyke-rork $(720)$ comes from Catherhal liockis at lit. It shows porphyritic erystals of habardorite (symmetral extinctions of about $28^{\circ}$ ) and green

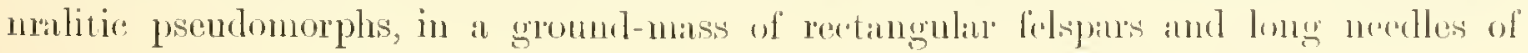


lnown horuhlende. Some of the felspar-phenocrysts are much decomposed, but show a narrow margin of quite unaltered material.

A chemilal analysis of sperimen 714 from $\mathrm{C}_{3}$ gave the following result under I:-

\begin{tabular}{|c|c|c|c|c|c|}
\hline & & I. & $\begin{array}{l}I_{A} \\
\text { mol. ratios. }\end{array}$ & $\begin{array}{c}\text { II. } \\
\text { (Banakite) }\end{array}$ & $\begin{array}{l}\text { III. } \\
\text { mean of }-(1) \text { and (5), (p. } 119\end{array}$ \\
\hline $\mathrm{SiO}_{2}$ & $=$ & $48 \cdot 22$ & $\cdot 80 t$ & $51 \cdot 46$ & $49 \cdot 11$ \\
\hline TiO.. & $=$ & $2 \cdot 09$ & $\cdot 026$ & $0 \cdot 83$ & $3 \cdot 06$ \\
\hline $\mathrm{Al}_{2}\left(\mathrm{O}_{3}\right.$ & $=$ & $18 \cdot 47$ & $\cdot 181$ & $18 \cdot 32$ & $19 \cdot 11$ \\
\hline $\mathrm{Fe}_{2} \mathrm{O}_{3}$ & $=$ & $5 \cdot 28$ & $\cdot 033$ & $4 \cdot 61$ & $2 \cdot 22$ \\
\hline $\mathrm{FeO}$ & $=$. & $3 \cdot 90$ & $\cdot 051$ & $2 \cdot 71$ & $6 \cdot 78$ \\
\hline $\mathrm{MnO}$ & $=$ & $0 \cdot 10$ & $\cdot 001$ & 0.17 & 0.08 \\
\hline $\mathrm{CaO}$ & $=$ & $6 \cdot 02$ & $\cdot 108$ & $6 \cdot 03$ & $6 \cdot 75$ \\
\hline $\mathrm{MgO}$ & $=$ & $2 \cdot 07$ & .052 & $2 \cdot 91$ & $5 \cdot 36$ \\
\hline $\mathrm{Nil}_{2} \mathrm{O}$ & $=$ & $4 \cdot 94$ & $\cdot 080$ & $4 \cdot 11$ & $5 \cdot 30$ \\
\hline $\mathrm{K}_{2} \mathrm{O}$ & $=$ & $3 \cdot 47$ & $\cdot 037$ & 4.48 & $2 \cdot 85$ \\
\hline $\mathrm{P}_{2} \mathrm{O}_{3}$ & $=$ & $0 \cdot 88$ & $\cdot 006$ & 0.86 & 0.39 \\
\hline $\mathrm{H}_{2} \mathrm{O}$ at $110^{\circ}$ & $=$ & 0.44 & $\lambda$ & & \\
\hline $\mathrm{H}_{2} \mathrm{O}$ above $110^{\circ}$ & $=$ & $2 \cdot 89$ & \} & $3 \cdot 89$ & \\
\hline $\mathrm{CO}_{2}$ and loss & $=$ & $(1 \cdot 23)$ & & & \\
\hline & & $100 \cdot 00$ & & $100 \cdot 38$ & \\
\hline
\end{tabular}

The Osimn formula of this rock is:-

$$
s_{60 * 41} a_{63} c_{33} f_{11} n_{6: 83}
$$

The formula for a banakite-dyke from Ishawooa Canyon, Wyoming," the analysis of which is given under II, is :-

$$
s_{60 \cdot 04} a_{51} c_{31} f_{11} n_{58}
$$

Calculation of the "norm" gave the following result :-

$$
\begin{aligned}
& \mathrm{KAlSi}_{3} \mathrm{O}_{3}=20 \cdot 57 \\
& \mathrm{NaAlSi}_{3} \mathrm{O}_{3}=25 \cdot 15 \\
& \mathrm{NaAlSiO}_{4}=8 \cdot 90 \\
& \mathrm{CaAl}_{2} \mathrm{Si}_{2} \mathrm{O}_{8}=17 \cdot 79 \\
& \mathrm{CaSiO}_{3}=3 \cdot 12 \\
& \mathrm{FeSiO}_{3}=3 \cdot 30 \\
& \mathrm{MgSiO}_{3}=5 \cdot 20 \\
& \mathrm{Fe}_{2} \mathrm{O}_{3}=5 \cdot 28 \\
& \mathrm{FeO}_{2} \mathrm{TiO}_{2}=3 \cdot 95 \\
& \mathrm{Cat}_{3} 2 \mathrm{PO}_{4}=1.86
\end{aligned}
$$

In the American quantitative system, the rock would be classed as Akerose, but a very slight difference in the ratio $\frac{\mathrm{K}_{2} \mathrm{O}+\mathrm{Na}_{2} \mathrm{O}}{\mathrm{CaU}}$ would refer it to Shoshonose, like the kersintite described above (p. 130).

Under III is appended the result of taking the mean of analyses (1) and (5) (see p. 119) of the olivine-basalt (656) and the leucite-kenyte (818) of the lioss Archipelago. Although it may have no real significanee, it seems worthy of note that the chemical composition of this ancient dyke-rock (714) should be so near the mean of the two

- Idlings, Monogr. U.S. Geol. Surv, 1899, No. 82, 1'art II, I. 347. Analysis by Eakins. 
principal products into which the magma appears to have been differentiated in the recent lava-flows. If the $\mathrm{FeO}$ and $\mathrm{Fe}_{2} \mathrm{O}_{3}$ are taken together, then no item in the two results, except that of the $\mathrm{ggO}_{\mathrm{g}}$, differs by more than 1 per cent. In these banakitelike dykes, too, oeeurs the basaltic hornblende which is so ubiquitous a mineral in the recent lavas. The rutio of $\mathrm{Na}_{2} \mathrm{O}: \mathrm{K}_{2} \mathrm{O}$ is also nearly the same as in the younger rocks.

Doubtfully to be referred to under the heading of banakite is the dyke-rock (566) intrusive in the crystalline limestone of the Northern Foothills at $G_{4 .}$. It is a darkgreenish-gray speckled roek, showing to the naked eye no phenocrysts. Under the microscope it is seen to be microporphyritic, with numerous small, sharply-defined phenocrysts of purplish augite, green chloritic and serpentinous pseudomorphs (possibly after hormblende) and a few altered felspars. The ground-mass consists of altered felspar prisms with shreds of biotite and hornblende and sparingly seattered magnetite-grains.

Of very similar character is the dyke (565) in the granite at $c_{6}$ above the liead of Blue Glacier.

The specimen (646) found by Lieut. Skelton in a moraine, ten miles beyond Cathedral Rocks, deserves mention here. It is a brownish-grey eompact rock, conspicuously porphyritie, and showing to the naked eye small prismatic felspars am a few crystals of augite and hornblende. Under the microscope are seen phenoerysts of oligoclase (symmetrical extinetions of $10^{\circ}$ ) and sharply-defined, nearly-colourless, augites in a base of felspar-laths; phenocrysts of basaltic hornblende are also sparingly distributed. The rock is altered, with development of much epidote in the phenocrysts of felspar and augite. 


\section{TIEE BEACON SANDSTONE ANU O'THER SEDIMENTART ROCKS.}

'T'H: liearon Sandstones are medinm-graned rocks, for the most part remarkably free from fermerinous or other coloured impurities. 'Jhe quartz-grains which compose them have doubtless been derived from the granitic and gueissic roeks, as they show lingid inclusions with bubles, and oceasionally numerous hair-like inelusions (rutile?) sucll as are often found in the quartz of granites. In some of the grains these needles oreur in lines perfectly straight and parallel to the directions of extinction. Acessory coustituents are rare in these sandstones, but in some specinens opaque and

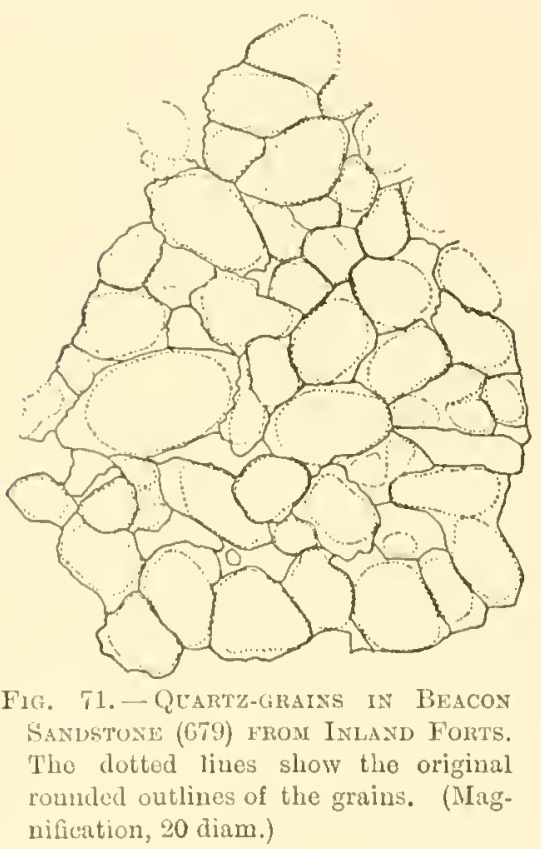
kaolinised white and pink felspars are plentiful. In a fine-grained quart\%-grit $(641)$ at the base of Finger Mountain are small irregular grains of pink garnet and rounded crystals of zircon and rutile, and in coarse-grained felspathic grits $(640,642)$ from the same locality oeeur large angular fragments of mierocline. In these grits the quart\%-grains are quite angular, but most of those in the ordinary sandstones are fairly well rounded.

The rementing material is siliceous and usually is not in large amount, so that the grains are loosely eohering, but in the "stalagmitic" and "marbled" sandstones, mentioned on p. 44, narrow seams of the roek have been converted into compact quartzite, owing probalbly to local infiltrations of siliceous material. Under the mieroseope such parts of the sandstone (679) show rounded graius of quartz eemented by aceretions of quart\% in crystalline continuity with the grains, as in the case of the stiperstones of Shropshire. Between erossed nieols the slide has the appearanee of interlueking irregular quartz-grains, but in ordinary light the perfectly rounded oval outlines of the original grains are clearly seen (see Fig. 71 , in which the dotted lines show the outlines of the original rounded grains).

Of the larger pelhles in the Beacon Sandstones, most consist of granitic quart\% with liquir inchusions and movirg bubbles, but one specinen (6:38) from below linger Mountain appear's to have been derived from an carlier sandstone, as it consists of rounded and snlb-angular quartz-grains cemented ly quart\%. Another peblile (675) from the sundstone minter $B_{1}$ consists of a quart\%-schist showing, under the microscope,

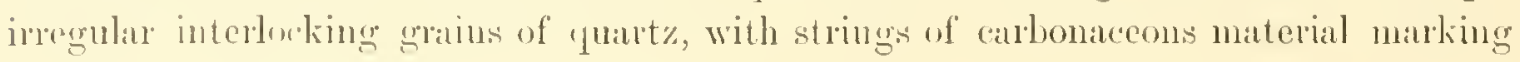


the foliation. Pebbles of fine-grained quartz-grits, obviously derived from granitic material, were obtained in the dredge off King Edward VII Land.

From various loealities eome specimens of dark micaceous schists, which under the mieroseope have much the appearance of eontact-metamorphosed sediments.

One of these specimens (96) eomes from Granite Harbour. It consists of subangular grains of quartz and some plagioclastic felspar, with strings of strongly pleochroic (from nearly colourless to deep reddish-brown) mica; grains of sphene are also plentiful. A very similar rock (578), but of finer grain, was found near the contact of the kersantite (579) with the crystalline limestone (576) at the north-east end of the Blue Glacier. Somewhat similar rocks, but of still finer grain and more slaty in appearanee, were found amongst the rock-fragments from the dredge, loth off Balleny Fslands (866) and off King Edward VII Land.

Black shaly to slaty roeks $(836,496)$ were ol,tained from moraines on the Blue Glacier and at the south-cast end of Black Island (525), and also from the dredge off Balleny Islands (866). 


\section{Chapter $V$.}

\section{THE DOLERITES.}

The dolerites, intrusive in the Beacon sandstone and the granite, are remarkably uniform in appearance and in microscopic characters, from Depôt Nunatak at the head of the Ferrar Crlacier to the Kukri Hills near its mouth.

The rock $(662)$ from Depot Nunatak is fairly typical of all the specimens (see Plate $X$, Fig. 1). It is a mottled gray-brown medium-grained dolerite, showing no porphyritic arystals. Under the microscope it is seen to be made up mainly of colourless angite, partly in long prismatic crystals, and partly in irregular sub-ophitic plates, and pligiochastic felspar (labradorite eliefly) in stout prisms and lath-shaped crystals. Grains of magnetitc and ilmenite are rery sparingly distributed.

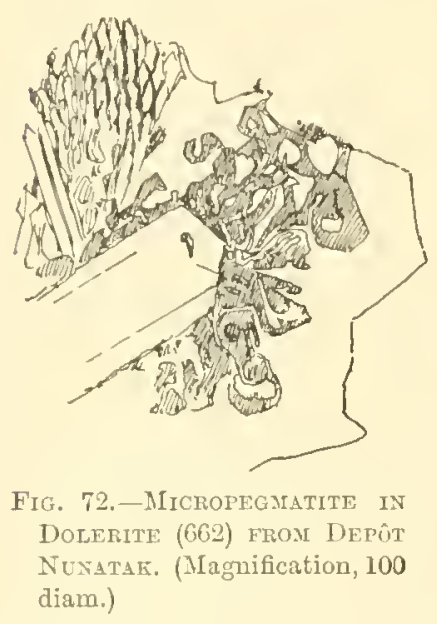

A eharacteristic feature of most of these dolerites is the presence, in patches and in the interstices of the angite and felspar, of more acid material, showing quartz in radiating (spherulitic) and micropegmatitic intergrowth with felspar. In the section of specimen (662) quartz is secn to hare erystallised round prisms of felspar, from the end of which springs a micropegmatitic intergrowth (sce Fig. 72).

In this respect, as well as in their general characters, these dolerites bear a striking resemblance to the so-called "augite-diorites with micropegmatite," which are intrusive in the gneisses and pyroxene-granulites of Southern India (Madras Presidency), and have been described by Dr. 'T. II. Holland.* In both cases the coarseness of grain of the micropegmatite varies directly with the texture of the rock, and thus one of the principal arguments used by Dr. Holland in favour of the primary origin of the micropegmatite is applicalle also to thesc Antaretic rocks. In some specimens, however, (e.y., 692 from Dry Valleys) this more acid and (in the case of this spccimen) finergrained felsitic material occurs in such distinct patches (up to $2-3 \mathrm{~mm}$. in diameter), with intcrspaces nearly free from it and consisting simply of the felspar-augite aggregate, as to suggest an intermingling of two rocks (granophyre and gabbro), such as occurs so commonly in Skye.i It is remarkable that in this rock the magnetite (in rod-like slieleton-crystals) is mainly confined to the more acirl patches. Some of the specimens of dolerite found (but not in situ) at Depôt Nunatak are gabbro-like in coarscness of grain, and in these the micropegmatitc is also coarse-grained, and constitutes practically the ground-mass of the rock. One of these gabbro-like rocks (632) contains olivine intergrown with the augite, which in this case is of the purplish titaniferous variety.

* IIolland, Quart. Journ. Geol. Soc., 1897, vol. liii, p. 405.

$\dagger$ Harker, The Tertiary Igneous Rocks of Skye. Mem. Geol. Surv. of the United Kingdom, 1904, P. 169. 
In certain specimens (698 from Dry Valleys and 661 from Knob Head) the mieropegmatitic patehes are not so prominent, but quartz is still present in the ground-mass. These rocks are of somewhat finer grain, and eonsist of a base, of small stout felspar-prisms with a little quartz, from which the eolourless augites stand out conspicuously in large irregular ophitie plates.

The augite in these dolerites gives extinctions of over $40^{\circ}$; the sections are for the most part without definite erystalline outline; most of them show the usual twinning on 100, and many of them also exhibit the "herring-bone" structure due to fine striations parallel to 001 in the two halves of a twin.**

The felspar-prisms in these rocks generally show Carlsbad-twinning. Albitetwinning is not so common, but in some scetions showing twin lamellæ symmetrical extinctions of $26^{\circ}$ were observed.

The result of a chemieal analysis of specimen 661 from Knol Head is as follows under 1 . Under II is given, for eomparison, the analysis of the "augite-diorite" from Madras referred to above.

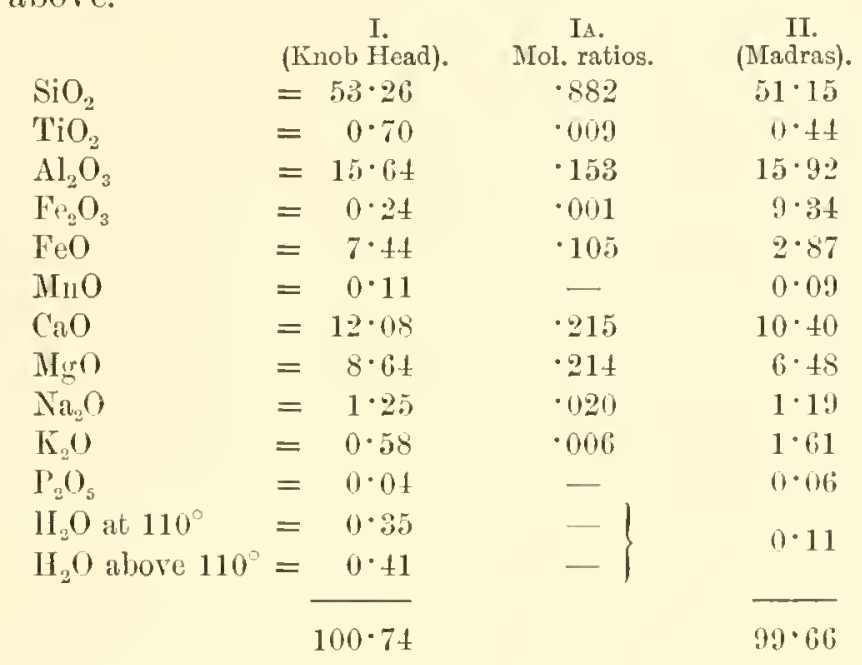

The Osann formula for this rock is :-

$$
s_{5546} a_{1} c_{41} f_{142} n_{762}
$$

which is near the formula for a basalt from Etna belonging to Osann's "Royat" type, viz. :-

$$
s_{54 \cdot 21} a_{1} c_{5} f_{14} n_{8}
$$

Calculation of the "norm" gave the following result:-

$\begin{array}{llr}\mathrm{KAlSi}_{3} \mathrm{O}_{8} & = & 3 \cdot 34 \\ \mathrm{NaAlSi}_{3} \mathrm{O}_{8} & = & 10.48 \\ \mathrm{SiO}_{2} & = & 3.36 \\ \mathrm{CaAl}_{2} \mathrm{Si}_{2} \mathrm{O}_{8} & = & 38.09 \\ \mathrm{CaSiO}_{3} & = & 9 \cdot 05 \\ \mathrm{FeSiO}_{3} & = & 13.72 \\ \mathrm{ISSNiO}_{3} & = & 21.40 \\ \mathrm{FeO} . \mathrm{TiO}_{2} & = & 1.37 \\ \mathrm{FeO} . \mathrm{Fe}_{2} \mathrm{O}_{3} & = & 0.35\end{array}$


In the American quantitative system the roek would be elassed as Auvergnose.

The contact-effects produced in the dolerites intrusive in the sandstone and granite respectively are of interest. In each ase the effects are similar, and due mainly to the surlden cooling. In place of a coarse-grained dolerite, the roek a few feet from the tontact has the characters of a hasalt, which becomes finer-grained and more glassy the closer it approaches the sandstone or granite; at the same time the felspar and augite become long prismatic, with the former often enelosed in the latter (see Plate $X$, Fig. 3). At one or two inches from the contact the dolerite changes from blaek to a pale-green colour. That the proluetion of this eompaet green aphanitie material is not due to any alsorption of siliea from the sandstone is shown by a determination of the siliea in it, which gave a result $51 \cdot 96$, actually lower than that obtained in the above analysis of the dolerite from Knol, Ilead.

In Plate $X$, Figs. 2-5 represent, as seen under the mieroseope, thin slices of specimens of dolerite eollected at different distanees from the contaet with sandstone.

Specimen 696 (Plate X, Fig. 2), from Dry Valleys, at $2 \mathrm{ft}$. from the sandstone, still shows some augite in ophitic patehes enclosing felspar-laths, bnt most of the pyroxene is in long prisms scattered through a base of felspar-laths, with interstitial felsitic material crowled with magnetite in rod-like skeleton-erystals.

Speeimen 687 (Plate I, Fig. 3), from Inland Forts, at 6in. from the sandstone, shows long interlacing felspar-laths and colourless augite dispersed about them and sometimes enclosing them, with interstitial patches of brown glass, dense with magnetite in rods and grains.

Specimen 695 (Plate X, Fig. 4), from Dry Valleys, at 2in. from the sandstone, shows a further stage in the passage to a glass. The rock is variolitic, and mnch finergrained than the preceling; it shows a few porphyritic felspars, lut consists mainly of raliating sheaves of felspar-needles, with interstitial glass dense with magnetite.

Finally, at the actual junction with the sandstone, the rock (sperimen 669 , from $\mathrm{B}_{1}$ ) is a pale-lonwn glass with dak-lorown chouded patches arranged in wavy lines roughly parallel to the line of contact (Plate X, Fig. 5). Close to the junction the magnetite is in feathery tulfs surrounder by alearer halos, lut at a few millimetres distance it occurs in more distinet grains; here also are seen one or two small porphyritic felspars and altered augites in a hase which is confusedly crystalline, with radiating sheaves of minute felspar-needles, as in the preceding specimen but on a finer scale.

Sperimens from the contact of dolerite and granite at $D_{2}$ in the Kukri Hills show sinilar characters, exept that in this case the chilling process has not proceeded so far. 'Thus sperimen 705 shows, at the actual junction, no glass, but exhibits characters intermoliate between those of specimens 687 (Plate X, Fig. 3) and 695 (Plate X, Fig. 4).

The dolerite (119) from Gianite. Harhour has the same eharacters as those of the dulerites of the Ferrar (tracier, and shows similar patehes of acid material. Specimen 154 from this locality is a peculiar lyybrid rock. It is a dark dolerite with numerons small 
(from 2 to $3 \mathrm{~mm}$. in diameter) rounder red patches of granitic material fairly uniformly distributed through it. Under the microscope (Plate $X$, Fig. 6) the main mass of the rock is seen to ennsist of small purple suh-ophitic augites, felspar-laths, magnetite-rorls, and green pseutomorphous hornhlende. 'T'he red patehes are composed of stout red and haolinised felspar-prisms, with a little interstitial quartz and a few shreds of biotite.

of interest in eonnection with the wide extension of the dolerite-sandstone formation (see p. 53) is the fact that amongst the pebbles dredged up off Cape Wadworth, and also to the south of the Balleny Islands, are some of dolerite like that of the Ferrar Glacier, and showing similar spherulitic and micropegmatitic patehes. Further, a pebble (866) from the dredge south of the Balleny Islands shows elaracters almost precisely similar to the "chilled" dolerite (687) from Inland Forts at the junction of dolerite and sandstone.

The dolerite fragments found in moraines on Mount Terror are similar to the dolerites of the mainland; some are very coarse-grained and gabbro-like, with coarsegrained micropegmatite, as in the speeimens from 1)epot Numatak deseribed above.

In a moraine off White Island was found a fragment (307) of typical olivinegabbro. Under the microscope it shows broad plates of labradorite with glomeroporphyritic groups of pale yellowish-brown diallage in large irregular plates and small olivines intergrown with the diallage.

In comnection with the dolerites, a peculiar conglomerate found on the west promontory of Black Lsland deserves mention. It consists mainly of rounded grains of cuartz and a little felspar (including microcline), cemented by calcite; but it also contains numerous fragments of dolerite, similar to that of the mainland.

\section{SUMILARY.}

The basement-rocks of South Victoria Land consist of crystalline limestones, gneisses and granites.

The erystalline limestones are remarkably free from accessory constituents, but some contain chondrodite.

The gneisses are metamorphosed granites (orthogneiss) and are often chararterised by prominent augen-structure and by cataclastic efferts.

Above the gneisses oceur masses of red and gray granites which pass ocrasionally in to more basic diorites or hornblende-gabbros.

Intrusive in these basement-rocks are dykes, rhiefly of lamprophyric rocks including eamptonites and kesantites, but comprising also yuartz-poryhyries and roeks themically allied to banakite.

Upon the granite has been deposited an extensive sandstone-formation in which some obscure eharred plant-remains have been found.

'Through the sandstones have been intruded very widespread sills and dykes of dolerite. This dolerite is very uniform in mineral-eomposition throughout wide aneas, 
and is eharaeterised generally by the presence in the ground-mass of patehes of a mirropegmatitic or spherulitie intergrowth of quartz and felspar. In this and other "haracters it strikingly resembles the so-called "augite-diorite," dykes of which break through the pyroxene-gramlites and gneisses of Southern hndia.

The sandstone-rlolerite formation of Sonth Victoria land appears to be very extensive, for fragments of the characteristic dolerite were noct with in most of the localities within the Antaretic Circle visited by the 'Discovery', and were found in the dredgings even as far north as near the Balleny Islands.

Finally, the islands off South Victoria land, from the Scott Istands in the north to the Ross Arehipelago in the south, as well as Cape Adare on the mainland, and in all probability many of the mountains, such as Mount Melbourne, which fringe the ecrast helow the main plateau, consist of voleanic roeks of comparatively recent date.

These volcanic rocks may be regarded as belonging to one petrographical province characterised by the association of homblende- and olivine-basalts approaching the limburgite-type, with very alkali-rich rocks of medium basicity romprising phonolitie trachytes and phonolites, and also alkaline-basalts or kenytes ahmost identical in mineral and chemical composition with the ancient rhomb-porphyries of Norway and the very similar recent lavas of Mount Kenya and Mount Kilimandjaro in East Africa.

A striking feature in the basalts of limburgite-type is the high perentage of titanic acid and the number of included coarse-grained nodules, many of which are felspathic and gabbro-like in character.

These voleanic rocks of South Victoria Land belong undoubtedly to the Atlantic group, although they occur along a coast which has been described as distinctly of the Pacific type.*

* While these pages were in the press, Band II, Theil I of the Deutsehe Südpolar Expedition (1901-1903) was published: in No. 2, 'Geologisehe Beschreibung des Gaussberges,' by E. Plhilippi, the author brings forward arguments in favour of the riew that the eoast of South Victoria Land is really of Atlantie type. 


\section{INDEX.}

A, see Map and Seetion I (Plate VII); and also Depôt Nunatak.

$\mathbf{a}_{15}$, see Map.

,, sandstone and dolerite, 41.

Ablation, of glaciers, 64 .

Actinolite, in diorite, 127 .

Aetinolite-rock, Cathedral Roeks, 31.

Adam (Monnt), z2:.

Adare (Cape), Fig. 6 (p. 17).

$, \quad 7,21,22,98,141$.

" analeite in basalt, 106 .

. basalts, 2, 17, 18, 101, 102, 106, 109 .

, deseribed, $17,18$.

" granites, 2, 32, 125 .

, icebergs aground, 75 .

," fhonolite, 116.

, re-sorted inoraines, 80 .

, geologieal sections, 18.

Acélie Land, granites, 1, 2.

Admiralty Range, 17, 19, 23.

$$
\begin{array}{ll}
, & \text { deseribed, } 22 . \\
. & \text { glaeiers, } 71 . \\
, & \text { pyramidal peaks, } 54 .
\end{array}
$$

Aegrine, in trachyte, 115.

Aegirine-angite, in kenyte, 113.

, in phonolite, 116 .

, in phonolitic traehytes, 114-116.

Ages, relative, of basalts and triehytes, 123.

Akerose, 132.

Alkalies, ratio of, in rocks, $122,138$.

Alkaline loasalts (see Kenytes).

Alkali-rieh roeks, association with basalts, 102, 1:1, 122,140 .

Allanite, in granite, 127 .

Analcite, in lanakite, 181, and Plate IX, Fị. 6.

$$
\text { , in basalts, } 106 .
$$

Analyses, "augite-diorite," Małras, 137.

.$\quad$ banakite $(714)$ from $\mathrm{C}_{3}, 132$.

,. banakite, Ishawoua ('unyon, 132.

,, basalts and traclytes, 119, 120.

" diorite (715), Cathedral Rucks, 127.

" dolerite (661), Knob Head, 137.

,$\quad$ hornblende-basalt, Härtlingen, 105.
Aualyses, hornblende-basalt (355), Snlphnr Cones, 103.

," "Iornblende-dialıase," Grüreneck, 115.

" hornblende-trachytes ( 277,275$)$, Olserration Ilill, 11!.

, lencite-kenyte $(81 \%)$, Cape Royds, $112,113$.

, kengte, Mt. Kenya, 113.

, kersantite $(5 \% 9)$ at $\mathrm{Q}_{1}, 130$.

, kersantite, Ntengerts, 13 1\%.

, limburgite (326), Rirlge Road, 105.

, mica-gabbro, Humicane Ridge, 127.

", nepheline, 11:.

, olivine basalt, near the Gap (656), $10 \%$.

., phonolite, Mont Mianne, 115.

, quartz-diorite, Sweet Cass Creek, 1ㅈ.

"rhomb-porpligry (kenyte), Kibo, 11:.

", rhomb-porphyry, Vasvik, 113.

" shoshonite, Beaverdam Creek, 130.

. traehyte (607), Brown Id., 115.

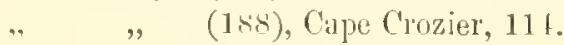

, $\quad$, Forolladi, 119.

, $\quad$, Scott Id., 114.

, trachydolerite, Campanario, 119.

Andes, volcanic rocks of, 122.

Aune (Cape), Coulman Id., 5 .

Anorthoclase, in bauakite, 131.

" kenytes and trachytes, 102, 111, 112,122 .

" phonolites, $116,117$.

," phonolitic trachytes, 114, 115, 11s.

Antarctic Continent, evidenee for, 2 .

,$\quad$ Expedition (German), 140.

" Manual, refs. to, 1, 2, 57,71 .

Anticline, Razur Baek Id., 12\%.

Apatite, in binakite, 131.

, in basalts, 102, ant Fig. 59 (p. 108).

$" \quad$ in diorite, 12\%, 128.

, in kenyte, 113.

Arler. F. A. Newell, Report on plant-remains, 4z, IB, IS.

Aretic Regions, ice-foot, 61.

$$
\text { , ice-caps, cte., } 99 .
$$

Armitage, lient. A. li., dulerite flom Depot Ninatak, 49 . 
Armitage, Gient. A. B., camptonite from Catliedral Rocks, 1:3. pimeerejourney np Fermar Glaricer, $89,49,56$.

Aruntage (('ipe), Figr. :3: (p. 88).

$$
\begin{array}{lll}
" & , & \text { basalt. 1:, 1116. } \\
, & , & \text { cracks in sea-ice, 5i), 60. } \\
. & , & \text { mater-lioles, 5i, 59. }
\end{array}
$$

Arrival Bay, Plate II

Arrival bay II cights, spe Ilarhour Ileights.

Atluntic type, Antaretic rorks of, $102,122,140$.

Anckland, volcanoes, 12.

Aucklind lskinds, Fig. 54 (p. 97).

$$
\text { ", } \quad \text { ". } \quad \text { described, 96,97. }
$$

Angen-rneiss, Cathedral Rocks, :30, :11, 125.

$$
. \quad \text { described, } 124,125 .
$$

, Granite Ilarbour, 126.

" Kunki IIills, $30,82,125$, and Plate IX, Fig. 1.

Augen-strncture, in gneiss, $124,125,139$.

Amgite, in lsmakites, 181, 189.

, in hasalts, 102, 10\%, 104, 106, 109.

,. in canponites, 129 .

,$\quad$ in contact-dolerites, $1: 3$.

, in doleritss, $1: 36,1: 7$.

, in kenytes, 111, 11:.

, in kersantites, 130, 1831.

, in nodnles in basalts, $107,108$.

, in phonolitic trachytes, 114-117.

"Angite-diorite," Madras, 1:36, 110.

Anvergnose, 138 .

$$
\text { , anal., } 137 .
$$

P, sep Finger Momtain.

$B_{1}$ (hill), see Map and Sections (Plate THI).

$$
, \quad 17
$$

," dolerite and sandstone, $40,41,45,49,50$, 1:3, and l'late X, Figr. 5.

.. fossil plant-rentinins, $10,41,42,4 x$.

" jeblules in sundstome, $11,1: 3$.

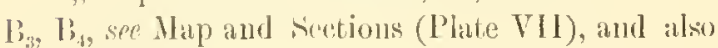
Beacon Ileights.

$b_{n,}$ New Mount, see Map and Plates V, VII.

$\mathrm{B}_{6}, \mathrm{~B}_{7}, \mathrm{l}_{\mathrm{x}}$, se Map) and Sections (Plate VII), and nlso C'erra ('utta Momntains.

Bi, saludstone and dolerite, 51.

li, sor Jap and heetions (Plate VII), and also linob llaud Nomnbain.

li (Inountain), se Map and Sections (I'late THI), and Fig. 2 s' (1.51).

$h_{1}$, see Map and l'late $\mathrm{V}$. $\mathbf{b}_{1}$, dolerite, 51 .

, sandstone, 45 .

$\mathrm{l}_{2}$, spe Map and Plate $\mathrm{T}$.

, crevasses, 70.

, dolerite, 46,51 .

, sandstone, 15,16 .

Bulanus Shells, in mormines, s0, $: 11$.

balleny, Capt. John, diseovery of Balleny Islands. 1, 2.

Balleny Islands, deseribed, 1, 2.

" dolerite, ete., from dredge. 3,135, 139,140 .

, icebergs, 74 .

,$\quad$ soundings, $: 3,94$.

Banakite, 1:9, 139.

, descrilued, 131-13:3.

, Cathedral Rocks, 131, 133.

" Ishawoua Canyon, anal., 182.

$" \quad$ Northern Foothills, :27, $35,1: 1-13: 3$, and Plate IX. Fig. 6.

, Torthern Foothills, anal., 132.

Bamner-shoal, Cape Adare, 75.

"Bare lioeks," basalt-tuffs, 110.

Barkevikite, in basilt, 10:3.

$$
" \quad \text { in tracligte, } 11 \% \text {. }
$$

Barne, Jient. M., records Lorizontal strneture, 54.

, morement of barrier, 69, 82.

,$\quad$ rocks from Bane Inlet, 26 .

Barne (Cape), easstal ice-fringe, 65.

$" \quad$ described, 9.

$" \quad$ basilt, 9,106 .

" basalt-agglomerate, $\%$

Barne Inlet, gneiss and granite, 26.

Baron, li., cavities in granites, ref., 8.9.

Barrier (Freat Iee), Fig. 38 (p. 6s).

$$
\begin{aligned}
& \text {, } \quad 10,24,64,79,81,1 \geq 4 \text {. } \\
& " \text { deseriber, } 67 \text {. } \\
& \text { " lummocks produced by, } 59 \text {. } \\
& \text {, icebergs from, } 7 \text { t. } \\
& , \quad \text { moraines, } 69 . \\
& \text {, movement of, (69, } 52,8.8 \\
& \text {, plessure-ridges, } 8.9,8: \text {, } \\
& \text { " snow on, st. } \\
& \text {, sonndings along, } 94 \text {. }
\end{aligned}
$$

Basalt, association with alkali-rich rocks, 10z, 121, $12 \cdot 2,140$.

, Anckland Islands, 96, $97,109$.

., Black ld., 11,106.

" lirown Id., 15, 10.4.

, ('ape Adare, 2, 17, 18, 101, 102, 106, 119.

, Cape Armitage, $1:, 166$.

, Capje barne, 9, 106. 
Basalt, Cape Crozier, 10, 11, 104, 105.

"Castle lioek, 12, 105, 106.

" Chemieal relations, 119, 120.

, Conlunan Island, 5, 6, 101.

" C'rater Hill, 12, 106.

.. Cruzier Cliffs, 10.

" describer, 102-106.

"flagments in tufls, 109, 110.

"Franklin Island, 1, 6.

" Granite Harbour, 39.

, Harbonr Heights, 12, 18, 104, 106, 108.

Inacessilile lsland, 16, 166.

, Mactnarie Tslant, $96,109$.

". Mimma Blutt, 리, 106.

, Mount Mellowrne, 20 .

"near the Gap, 101-106, 121, 122 (Fig. 67), and Plate VIII, Fig. 1. anal.,

"Mount Terrol, 10, 11, 10:, 105.

. nodules in, 1:2. 1:, 106-109, 110.

, Observition Hill, 1 ,?.

, Possession Islands, 1, 4, 5 .

" lioss Arehipelago, 102-109.

, Razor Back Island, 16.

, Sulphur Cones, 11, 12, 104, 105.

" $\quad$ anil., 103, 119, 120.

. Snltan's Hearl, 11, 109, 110.

, 'lurtle Back Islitnd, 14, 106.

, V-Clifis IIogstaek, 11 .

, White Island, 15, 10 .

, wind-effect on, 88 .

, Winter Quarters, 11-18, 104, 105, 123.

, Young Island, 1, 2.

Basalt-agglomerate, Cape Barne, 9.

, Coulnan Islanı, 5, 6.

, Mount Terror, 10.

, Tent Island, 16.

Bisalt-class, Crater llill, 12.

$$
\text { , in tuffs, } 110 \text {. }
$$

Basalt -tuffs, 11, 109, 110, see also Tufts.

Basement-roeks, Sonth Victoria Land, 25-38, 101, $124-128,189$.

Bay-iee, 57 .

Beacon Heights $\left(B_{3}, B_{4}\right)$, see Plate $V$, and Scetions (Plate VII).

$\begin{array}{lll}, & 39,45,46 . \\ " & \text { eaps of dolerite, } 53 . \\ \text { " } & \text { granite in moraines, } 38 . \\ \text { sandstone and dolerite, } & 46 .\end{array}$

Beacon Sandstone, 2:8, 82, 88, 94, 98, 99, 101.
Beaeon Saudstone, Beneon lleiglits, 38.

$$
\begin{aligned}
& \text { described, } 39-51,1: 4 . \\
& \text { extent of formation, } 5: . \\
& \text { fossil plant-lemains in, 10-4., } \\
& \quad 46-48,99,139 . \\
& \quad \text { (see also Sandstone.) }
\end{aligned}
$$

Beanfort Island, deserilyed, 7 .

Beaverdim Creek, shoshonite, anal., 180.

Becke, F., Atlantic and Paeific type of voleanic rocks, ref., 123.

, lormblende-psendomorphs, ref., 108.

, roeks of Mittlegeluirge, ref., 121, 122.

, tracliytes of Columbretes, ref, 117,118 .

Bergschrmul, Inland Furts, 9:3.

Bernachi, L.C., glaeiers of liubertson Bity, ref., 71 . south-east journey, 67 .

Bernacehi (Cape), 20, 30.

$$
, \quad \text { piedmont, } 66 \text {. }
$$

Biotite, in lanakite, 183.

$$
\begin{aligned}
& \text { " gneiss, 1t, 125. } \\
& " \text { granites, } 125,124,128 . \\
& \text { " kersantites, 180, 1:1. } \\
& \text { " nodule in basalt, } 117 .
\end{aligned}
$$

Bird (Cipe), 8.

Bird (Mount), ৪.

$$
\text { " described, } 10 .
$$

Black Island, Fig. :3:2, (p. 5ic).

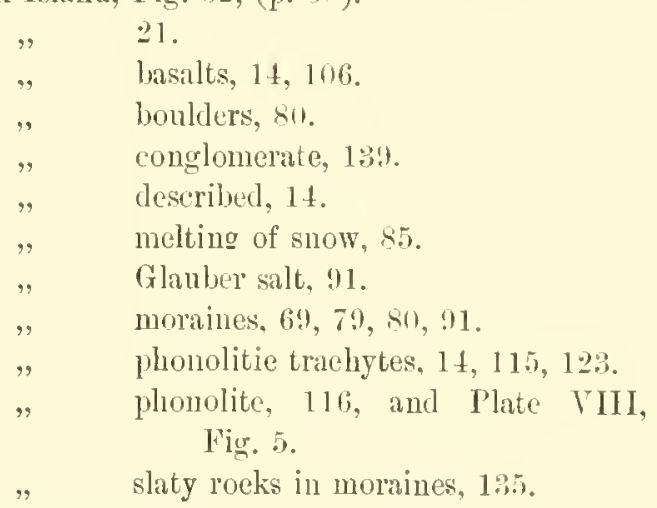

Block-f lacture, 123.

Blue glacier, Fig. $5 t$ (p, 90).

$$
\begin{aligned}
& \text {, } \quad 25,26,27,33,66,133,135 . \\
& \text { " débris-eones, } 81 \text {. } \\
& , \quad \text { described, } 70,71 \text {. } \\
& , \quad \text { diorites, } 12 \mathrm{~s} \text {. } \\
& \text {, icelveress, } 78,91 \text {. } \\
& \text { " rate of movement, } 82 \text {. } \\
& \text { " roek-débris in, } 77,78 \text {. } \\
& \text { " slaty roeks in moraines, } 185 .
\end{aligned}
$$

- Bluff,' The (see Minna lihuff).

Bombs, basaltie, 12:.

, Cape Croziel, 11. 
Bomls, Harbonr IIciglıts, 12, 106.

V-Cliffs Il oughtrak, 10.

Bonney, 'T. (r., cavities in granites, ref., s.9.

,$\quad$ conservative action of ice-fringe, ref., $61,93$.

"Tolcanoes," ref., 95.

Borchgrerink, C. E., rocks from Cape Adare, 2 .

Romodiaile Island, deseribed, 2,

I'ossession Ids., 4.

Bonlders, Anckland Islands, !

, Ferrar (ilacier, 79.

" Knob Ilear, $3 \times, 76,77$.

, near Blaek Island, \&o.

., Winter Quarters, s.

Brewster (Mount), voleano, 19.

Brögger, W. C., graphical representation of rocks, ref., $1 \geq 1$. solvsbergites, ref., 114.

Brown Island, basalt, 15, 104.

$"$ described, 15.

, moraines, 15.

, phonolitie trinehyte, 15, 115.

,$\quad$ water-action, 90 .

Bnekle Island, 7 .

,$\quad$ active volsano, $\therefore$.

Bnll Cliff, phonolite, anal., 121.

Burma, choudrodite in limestone, $12 t$.

C, North-Trest Monntain, sep Map.

$\mathrm{C}_{1}$, see Map and Fig. 20 (1. 42), and also Round Mt.

$\mathrm{C}_{3}$, sep Obelisk.

$\mathrm{C}_{6}$, spe Map and p. 12.

$\mathrm{C}_{\text {i. }}$. see Map and p. 5ol.

$\mathrm{C}_{\text {g, see Map and p. 12. }}$

$\mathrm{C}_{9}$, see MIap and IVest Fort.

Cale-schist, Nomit Terrol', 1:1.

Culcite, in busalt-tuffs, 110.

, crystalline limestones, $1 \geq 4$.

Calciun carbonatr, crinst on hollowed granite, $88,89$.

deposit on boullers, 91 .

Cancl's IImmp, spe l'late III, and Fig. 17 (p. 35).

Campanario, trachytolerite, anal., 119, 121.

Camptonite, 129, 13\%.

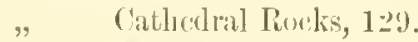

, Montreil, 12s.

, New llarbour Ileiglit, 12!).

, near Koettlit\% (Ilaci(1', ly!), and I'late IX, Fig. 5.

C'ape Aditle, ctc., sep Adilre, cte.

Carbonibeous matter in sandstone, 40-12, 4s, sec also Fossil.
Castle Rork, see Fig. 4 (p. 9) ; Fig. 36 (p. 61).

$$
\begin{aligned}
& \text {, } 11 . \\
& \text { " basalt, } 12,105,106 \text {. } \\
& \text {, basalt-tuffs, } 109,110 . \\
& \text {, described, } 12 . \\
& \text {, frost-riven, } 92 \text {. } \\
& \text { (p. 103). } \\
& \text {, ice-fringe, } 61,62 \text {. } \\
& \text { olivine-nodule, } 10 \text { s. } \\
& , \quad \text { wind-action, } 8 \% \text {. }
\end{aligned}
$$$$
\text { , hornblende-psendomorphs, Fig. } 59
$$

Cataclastic strueture, in gneiss, 125, 139, and Plate

$$
\text { IX, Fig. } 1 .
$$

,,$\quad$ in granite, 126 .

Cathedral Rocks $\left(\mathrm{E}_{1}-\mathrm{E}_{3}\right)$, see Plates III, IV, V, VII (Seetions), and Fig. $14(\mathrm{p} .29)$,

Fig. 17 (p. 35), Fig. 27 (р. 583).

, $\quad 25,38,70,98$.

, described, $30,31,35,36$.

, binakite, 131,133 .

, basalt from scree-slope, 106.

" eamptonite, 129.

, diorite, $30,36,127$, and Plate IX, Fig. 2.

dolerite and granite, 30,35 (Fig.

" dolerite and gran , $86,53$.

, flost-aetion, 92 .

", glicier, 71 .

, gneiss, $30,31,35,36,125$.

, granites and diorites, $30,35,36$, $5: 3,127$.

", molaine, 79.

, permatite, 31.

$" \quad$ sandstone, 30, 35.

, minderentting by water, 89.

Cavities, in granite boulders, 34, 87-89, and Figs. $16(1.84)$ ant $50(1) .87)$.

Cirques, 64.

, Inland Forts, 7:3.

'(Challenger' Expledition, dredgings, 2, 39.

Chamberlin, R. .J., iee-ea]s, ref., 63.

Chaunockites, India, 125.

Clemical action, in denudation, 91,99.

Clemical relations of rolcanic rocks, 119-1:3.

"C"himneys" of dolerite at Inland Forts, 50.

" Climney talus-shoot," 92.

Clilorite in altered dolerites, 109, 12న.

Chondrodite in crystilline limestone, 121, 139.

('brome-diopside in nodnles in busalts, 107.

Clarke, F. W., analysis of nepheline, $11 \%$

$$
\text { , amalyeis of diorite, } 127 .
$$

Classification of rocks, 120,121 . 
Clay, Auckland Islands, 97.

„from sea-floor, 94.

, Macquaric Island, 95.

Cliff-glaciers, 64, 7ə, 73.

Climate, Antaretic regions, 48.

Colberk, Capt. W., discovery of Scott Islands, 3. floes, ref., 57 .

Colbeck (Cape), 68.

Cols at Inland Forts, 42, 78.

Colnmnar structure, in basalts of Auckland Islands, 96.

in Jolcrites of Ferrar Glacier, 49, 51, 52 (Fig. 20 ).

Concretions, ferruginons, in sandstonc, 44 .

Cunglomerate, Black Island, 139.

Contalet-effects, dolerite and granite, 52, 18. , dolerite and sandstone, 50, 198, and Plate X, Figs. 2-5.

Continental Range, decribed, 21.

Cornish, Vaughan, forms of smow-dnues, ref., $8 t$.

Cornwall, altered dolerites of, 12s.

Corric-glacicrs, agrgrading, not cxcarating, valleys, 93 (Fig. 56).

, described, 6t, 78.

" Iuland Forts, $7:, 98,94$.

Corsica, cavitics in granites, 89.

Cussylite in luasalt, 103.

in phonolitic trachytes, 11t, 116.

Coulman Island, Fig. : (p. 5), Fig. 56 (1.93).

$\begin{array}{ll}, & 7,17,18,101 . \\ , & \text { basalts, } 5,6,101 . \\ & \text { corrie-glacier, } 9: . \\ & \text { described, } 5 . \\ , & \text { lorizontal structurc, } 5 . \\ , & \text { piedmont-glacier, } 66,67 . \\ , & \text { quartz-grit from dredge, } 39 . \\ , & \text { trachyte from dredge, } 115 .\end{array}$

Cracks in sea-ice, 59, 60 .

Crater IFill, sce I'late II.

, $1:, 19$.

. lusalts, $12,106$.

, descrilsed, 12.

, glaciel-ice fringe, 62 .

"Creep," of sen-ice, 60 .

Crevasses, in Ferrar Glacier, 70.

., Mount Erelıs, 70.

, temperature of ice in, 86 .

Cross, W., clissification of rocks, ref., $1 \geq 0$.

Crozier (Cape), see Fig. 5 (1. 10).

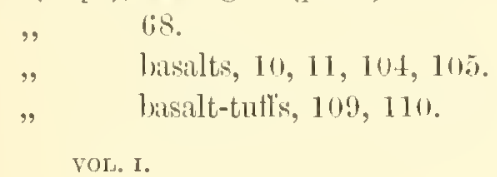

Crozier (Cape), bombs, 11.

$$
\begin{aligned}
& , \quad \text { bonlders of sandstone, ete. } 11 . \\
& , \quad \text { limburgite, 11, 104. } \\
& , \quad \text { plonolitic trachytes, 11, 114, 115. } \\
& , \quad \text { stranded moraines, } 1 . \\
& \text { wind-effect on trachyte, ss. }
\end{aligned}
$$

Crozier Cliffs, basalts and trachytes, 10.

Crist-block, fanlted, Royal Society Range, 5.8.

Crystalline Limestone, see Limestone.

Crystals of ice on fishing-linc, 55 (Fic. 29).

, of Glauber Salt, see Glamber Silt.

Current-bedding, in sandstone at $B_{1}, 41$.

$\mathrm{D}, \mathrm{D}_{2}-\mathrm{D}_{4}$, sre Map and Sections (Plate VIl), aud also Kukri Hills.

D (hill), dolerite-talıs, 92.

, granite and dolerite, 36, 37, 34, 52.

, hanging valley, 72 .

, nnderentting by water, 89

$D_{1}$ (hill), granite and dolerite, 37 .

$\mathrm{D}_{2}$ (hill), see Plate III.

, granite and dolerite, $36,37,38,52,13$.

$\mathrm{I}_{3}$ (hill), see Plates III, IV.

, granite and dolerite, $3 \mathrm{~s}^{\circ}$

$\mathrm{D}_{4}$ (hill), see Plates III, IV, and Fig. 14 (p. 29)).

, angen-gneiss, 30, 34, 125.

, crystalline limestont, 29.

$" \quad$ granite and dolerite, 36,38 .

,$\quad$ langingr valley, 72 .

., icc-clifl with rock-debris, $76,77$.

, moraines, 77 .

$D_{5}, D_{5 a}$, sef Map and Plate VII, and also Solitary Rocks.

$\mathrm{D}_{5}, 69,70$.

1) 5 , 70 .

$\mathrm{d}_{3}$, see Map.

, dykes, 35.

I)ailey Islands, described, 15.

$$
, \quad \text { limburite, 15, } 106 .
$$

I)amenherg, A., felspathic nodules in hisialts, lof.. 107 .

$$
\text { , sindstonc altered by linsilt, ref., }
$$
105 .

David, T. W. L., rocks from Possession Islands, r.f., 1.

Deas Head, columnar basalt, 96.

Debris-cones, McMrurlo Sound, s1.

Dellbridge Islands, deseribed, 16. ," rocks of, 10 .

Delta it Ianric IIarbour, 97.

I)enudation, Sonth Victoria land, si-94, 99.

Depôt Nunatak (A), Fig. 24 (1.49), Fig. 25 (1) . Bi). 
Depot Nunatak, 41), 69.

, crevasses, 70.

. dolerite. 19, 50, 186, 1899, and

Plate X, Fier. 1.

mulstone-lenticles, 41 .

.. $\quad$ sandstone in moraines, 40,41 .

talis from, 78

Descent I'ass, 30 . "1p-thrust of morinic material, 82 .

, hollowed granite-bonlders, s7, 8..

, morailes scen from, 78 .

Diallase, in gabbro, 139.

Diatoms, sea-floor along Barrier, 94.

I) iflerentiation, 1:21.

Diorite, $1: 39$.

„ Blue Glacier, 27, 12s, and Plate IX, Fig. 3.

, Cathedral Rocks, :0, 36, 127, and Plate

IX, Fig. 2 .

" anal., 127.

" described, 125-128.

, King Edward VII Lind, 128.

, Sweet Griss Creek, anal., 127.

Diorite-gneiss, Cathedral Rocks, 125.

'Discovery,' at Cape Jones, 19 (Fig. 7).

,$\quad$ at Macquarie 1sland, 95.

, break-np of ice, 59) (Fig. 38).

, Soundings along Barrier, 94.

'Diseovery' Expedition, geologieal work of, 98. Discovery Gulf, 70,71 .

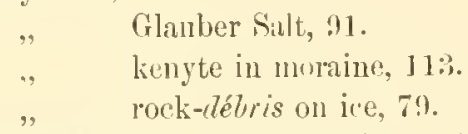

Diseorery (Mount), 7, 15, and Fig. $9: 2$ (1. 5.

$$
\text { , }
$$$$
\text { deseribed, } 20 \text {. }
$$

Distanees, Table of, 7 .

Distribution, of icebergs, 75 .

Dolerite, at $5.40,41,45,45,50,188$, and Plate

$$
\mathrm{X}, \mathrm{Hig} .5 \text {. }
$$

at $h_{2}, 46,51$.

., at $x,+6$.

: Beaeon Heiglits, 16 .

" rathedial liocks, :31, 35 (Fig. 17), $36,5.3$.

, contirst with granite, 52, 133 .

" contaret with sandstone, $49-54,135$, and

Plitte X, l'igs. :-5.

('ormwill, 1소.

,. Welot Numatiz, 4l) (lig. zt), 50 (Fig. $25), 13(6,1399$, and Plate X, Figr. 1 .

(les(riberl, 1?-54, 1:3(i-1:39.

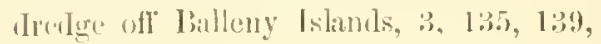
140.
Dolerite, Dry Valleys, 45, 46, 136-13s, and Plite $x$, Figs. 2 and 4 .

, Finger Molntain, to (Fir. 1!), +1, 1\% (Fig. 22), , :1), 11.

framents in rongloneristr, 1:s:.

, frust-riction un, $12 \%$.

, (iranite Itarbom, 3:2 (Fig. 15). 33:3. 5.t. $126,1: 3$.

gullies produced by, 92 .

, in moraines, $11,59,81$.

" Inland Forts, 42, 4:, $44,50,53,138$, $18 ! 1$, and Plate $\mathrm{X}$, Fig. :..

, linob llead Mountain, 46, 47, 49, 51, 52 (Fig. 26), $53,137$.

, Kukri IIills, 36, :37 (Fig. 1s), 38, 50, 5.3 (Fig. 27), $128,136$.

Macquarie Island, :9, 10\%.

$" \quad$ Royal Soeiety Range, 5., 49.

, Solitary Rocks, 36.

"South Victoriti Land, 25, 49-54, 98, 9!9, $101,1: 36-140$.

Terra Cotta Mountains, 47 (Fig. 23).

weathered surface of, 8 s.

" with granitic patches, 138, 139, ant Plate $X$, Firg. 6.

formation, extent of, $5: 3,54,140$.

Drift-iee, 57 .

Dry Valleys, sce Plates V and VII.

, 70

,$\quad$ dolerite and sandstone, 45, 46, 1:36, $1: 37,13$, and Plate $\mathrm{X}$, lige. 2 and 4 .

, dolerite-talus, 92.

, granite in moraines, ::8.

, moraines, 78 .

Dryogalski, E. von, icc-cricks, ref., 83.

, , ice-fringes, ref., 61.

" " Karajak ice-stream, ref., $7 x$

" $\quad$ " Kryokonit, ref., 9:3.

" , $\quad$ land-ice, ref., 6:, 64.

$" \quad$, salinity of sea-iee, ref., 5.5.

, , $\quad$ temperatme of ice, ref., st.

,$\quad$ " thawing of ice, ref., 85.

Dryoulski Jierlmont, 67.

Dune-snow, 8.1 .

Dyke-1ocks desiribed, 27, 1:9-1:3:

Dykes, Busalt at Ancklani Islands, !)

$, \quad, \quad$ at ('il) Adare, 17.

$" \quad, \quad$ all Comluman Island, 6.

", at Miceyuaric Islanrl, 9)(i.

,$\quad$ " at Diiley Islands, 16.

,$\quad$ lolerite at $\mathrm{I}_{6}, 51$. 
Dykes, dolerite at Finger Mountain, 51.

, $\quad$, $\quad$, at Terna Cotta MIts., 17 (Figr 23 ), 51.

., Granite Harbour, 33.

, granite at Cathedril Roeks, 31.

, trachyte at Olsservation Hill, 13.

E (hili), se Map and Seetions (Plate VII), Fig. 14 (1. 29), and also 'Table Mt.

, granite and dolerite, 36 .

$\mathrm{E}_{1}-\mathrm{E}_{3}$, see Map and Sections (I'late VII), and also Cathedral Roeks.

$\mathrm{E}_{1}$ (liill), see Plates III, IV, and Fig. 17 (p. 35).

, diorite, 30.

$\mathrm{E}_{2}$ (hill), sre Plate III and Fig. 17 (p. 35).

" banakite, 181 .

, diorite, 127.

" granite and gneiss, 30, 35, 36 .

, glacier, 71 .

$\mathrm{E}_{4}$ (hill), sce Mal) and Sections (Plate VII), and also Snow Valley.

, granite, 34 .

, kersantite, 34, 131.

$c_{5}$ and $e_{6}$, sec Map and Sicetions (Plate VII), and also Nhow Valley.

$e_{5}$, rranite, $: t, 126$.

$\mathrm{C}_{6}$, dyke-rock, 138.

, erranite, : $) 126$;

$\eta_{1}, \eta_{2}$, sef Map, and also nnow Valley.

"rimite, $3: 3$.

Earth-movements, affecting sandstone, 9!!.

Wust Africa, roeks of Atlantic type, 102, 12:2, 140 .

Bast Fork, see Plates IV, VII.

" $2 ., 52,69$.

,. erevasses, 70 .

, ice-movement, $s \%$.

,$\quad$ moraines, 78.

linst (troin, see Fig. 20 (p. 42).

, dolerite, 50.

, silndstone, $42,4:$.

Eden (Mount), basalt, 96.

Emlen, R., growth of iee-grains, ref., 68 .

Emmons, 1. B., analysis of phonolite, $115,116$.

Enderby Island, basalt, 97 .

Englaeial matcer, $76-78$.

Enstatite in olivine-nodules, 107.

Epidusite, Granite I Larbour, 126.

Epidote, in hanakite, 1:38.

, in weathered trachyte, $114,117$.

Erebus Bay, 1t, 110.

, kenytes from islinds, $14,16,110-113$.

Erebus Cove, elay and bonlders, 97.
Erebus (Mount), sce Fig. \pm (1).9).

", $\quad 7,10,16,20,22,95$.

, aetive voleano, 98 .

, erevasses, 70.

" deseribed, 8-10.

,$\quad$ glieier-iee fringe, 62 .

$" \quad$ iee-cap, 65.

$" \quad$ kenytes, 9, 1t, 102, 110-119, 12\%.

". moraines, 81 .

'Erebus' and 'Terror' Expedition, 1.

Essexite, Bhe Glazier, 128.

" Snow Valley, 126.

Esserose, 120.

Etna (Mount), von Waltershausen, ref., !.

Erans, J. W., ronnded quartz in gneiss, ref., 12t.

False-bedding, in sandstone at $B_{1}, \pm 1$.

Fast-ice, 57, 60 .

Faulting, in dolerite at $\mathrm{B}_{1}, 50$.

(tangential), 128.

Fearnsides, W. G., 100.

Felspar, in altered dolerite, 128.

, basalt-tufi, 109, 110.

,, contaet-dulerite, 138.

,, nodnles in lisalts, 107-119.

, sandstones, 1 is.

, schists, 130.

Fernando Noronha, 12:3.

Ferrar Glarier, see Plates III, IV, V, and Fig. 14 (p, 2:9), Fig. t: (p. 7s)

$" \quad 27,28,80,82,84,85,40,45,46$, $50,59,54,60,71,73,7+76$, $92,99,126,138$.

, boulders, 79.

, ehange from snow to ice, 85 .

, cracks, 8:\%.

, described, 69, 70.

, ice-falls, 69 , $18 .$.

" Lient. Armitage's journey, 39, 49, 85.

, moraines, 70, 78 (Fig. 43 ).

, rate of morement, 82 .

Ferrar, II. T., morement of Blue Glaeier, ref., 70.

, pimacled ice, ref., 15, 90.

, relitive ages of basalt and traehyte, 123.

, Report on Field-geology, 1-99.

, roek-specimens collected by, 101 .

Ferrera, "tephritie trachyte," 118.

Field-geology, Report on, 1-95.

Fieli-iee, 57, 60.

Finekh, L., analysis of kenyte, 113. 
Fincklı, l, rhomb-porphyries from Kilinmendjaro, l'ef., 111-113.

Fingel Mountain (B), see Plates V, VIl, anl Fig.

$$
\begin{aligned}
& , \quad \check{n}(1), 69 . \\
& \text { " erevassen, } 70 \text {. } \\
& \text { " . dulerite and siandstone, 14, 15, } \\
& 50,51 \text {. } \\
& \text { grit, 124, } 134 .
\end{aligned}
$$

Finland, elondrodite in limestone, 12 1.

Fiords, Aneklind Islands, 96.

Firnfield, 6:3, 64 .

lirmmulden, 63.

Floating piermonts, see Piedmonts-aflout.

Floe-iee, 50, 5i, 60 (lig. :3t).

flowers (ice-), 56.

Fhitidal structure, in basalts, 104.

Folding of rocks, $6,18,:$,

Foothills, between Cape Adare and Cape IV ashington, 22.

.. Cape Jones, 18.

"Nonnt Morning, 20 .

, Royal Society Range, 2?.

"S. of Capre Pernachi, 20.

See also Southern Foothills, Northern Footliills.

Foraniniferi, sea-floor along Barrier, 94.

Formule (Osinn), of roeks, 121, 127, 130, 1:22, 137.

Forodiula, "tephritic trinchyte," 117, 11 s.

, " , ",$\quad$ mal., $11 \%$.

liussil plint-lematins, in silndritonc, 10-42, 13, 1618, $99,109$.

Fianklin Island, 7,111 .

$$
\begin{aligned}
& \text {, lakilt, 1, 6. } \\
& \text {, descriherl, } 6 \text {. } \\
& \text {, limburate, } 6,101,107 \text {. } \\
& \text { " olivinc-norlules, } 107 \text {. } \\
& \text {, stranded moritines, } 81 .
\end{aligned}
$$

Fringe of whacier-iec, $61,(i 2$.

Fost-action, !:2, 99.

$\mathrm{G}, \mathrm{G}_{1}, \mathrm{G}_{2,}, \mathrm{G}_{4}$, see Map, and also Northern Foothills.

(: (hill), see Figs. 1.t (1\%.2!) and 54 (p. !)

(:, (lill), kersintite-rlyke, :27, 1:31), 185.

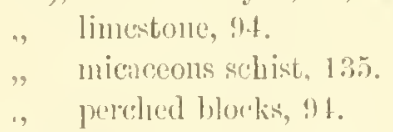

(i., (liill), ser Plate IV, and Fig. 1 ( (1. :?!).

, :3:?.

(i. (liill), gneiss, $27,28,30,34$.

$$
\text { , icc-crueks, 8\%. }
$$

$\mathrm{G}_{3}$ (hill), see Map and Plate IV.

, banakite-dyke, 35, 131.

"gneiss, 27, 28.

" granite, $33,34,: 35,36,88$.

,$\quad$ nnderenting by water, 89 .

$\mathrm{G}_{4}$ (hill), erystalline limestone, 26,27 (l’ig. 1:2).

g (liill), sce Map and Plate IV.

, 27.

$\gamma_{1}$, see Map and Plate $Y$.

, 50.70.

$\gamma_{2}$, sce Map).

, dolerite and sandstone, 42.

$\gamma_{3}$, see Map.

, dolerite and sandstone, 50.

Gabhro, Granite Harbour, 126.

, Ifurrienne Ridge, anal., 127.

, moraine off White Island, 139.

Gabbro-like nodules, in basalts, 107-109.

Gap (The), see Plate II.

, 13.

"basalt, 104-1166, 119-122 (Fig. 67), 132, and Plate VIII, Fig. 1.

, , anal., 105, 119, 120 .

, ealeinm earbonate on boulders, 91.

., nodule in limburgite, 108.

Garnet, in sandstones, 134.

Gurwood, E. J., iee-sheet, ref., 63.

$$
\begin{gathered}
\text { Irory Glaeier of Spitzbergen, } \\
\text { ref., } 78 . \\
\text { mp-tlumst of morainic material, } \\
\text { ref., s\%. }
\end{gathered}
$$

Gils-bubbles, in angites and felspars, $107,10 \mathrm{~s}$.

(ibuss (Cape), piedmont, 66, 67.

Gauss (Nolunt), 7, 140.

Geikie, $\Lambda$., land-iee, ref., 63.

Gorge Nurray (Mount), 2.2.

G(oman Antaretic Fxperlition, 140.

Glikcier-iee, fringes, (1, 6:.

McMurdo Sound, !) (lig. 51).

Glacier-talle, l'ig. $4-1$ (p. 79).

Glacicrs, 9:3.

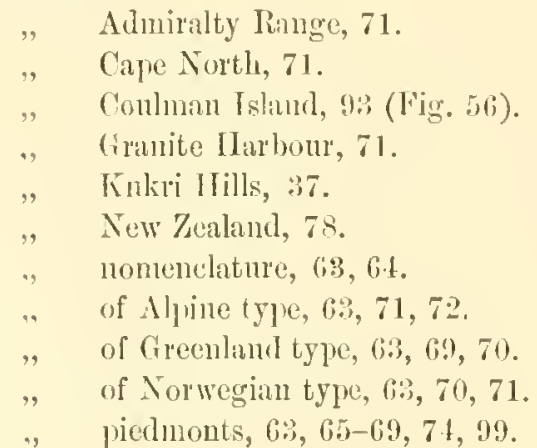


Glaeiers, Prince Albert MIts., 69.

$$
\begin{array}{ll}
, & \text { Robertson Bay, 71. } \\
, & \text { Round Mountain, 73. } \\
\text {, } & \text { roek-débris in, 76. } \\
\text {, Switzerland, 7s. }
\end{array}
$$

Glaciers remaniés, 64 .

Glass, in basalt, 101, 105.

, in contact-dolerite, 188.

, in kenytes, 111.

Glauber Salt, deposits of, 11, 91 .

$$
\text { , water-determination, } 91 .
$$

Glaze, on weathered stones, 87.

Gneiss, 98, 101, 189.

$$
\begin{aligned}
& \text { " Barne Inlet, } 26 . \\
& \text { " Blue Glacier, } 70 . \\
& \text { " Cathedral Roeks, } 30,31,35,36,125 . \\
& \text {, 'Challenger' drectgings, } 2 . \\
& \text {, Greenland, 124, 125. } \\
& \text { " King Eilward VII Land, 2 t, 12s. } \\
& \text { " Kukri IIills, 30, 88, } 125 \text {. } \\
& \text {, Madras, 186, } 140 . \\
& \text {, New IIarbour IIeight, } 28 \text { (Fig. 13), 29. } \\
& \text {, Northern Foothills, } 27,28,30 \text {. } \\
& \text {, Royal Society Range, } 25 .
\end{aligned}
$$

Gneisses, described, 25-31, 124-125.

Göller, E., analysis of kersantite, 130.

Granite, 25, 98, 99, 101, 131, 139.

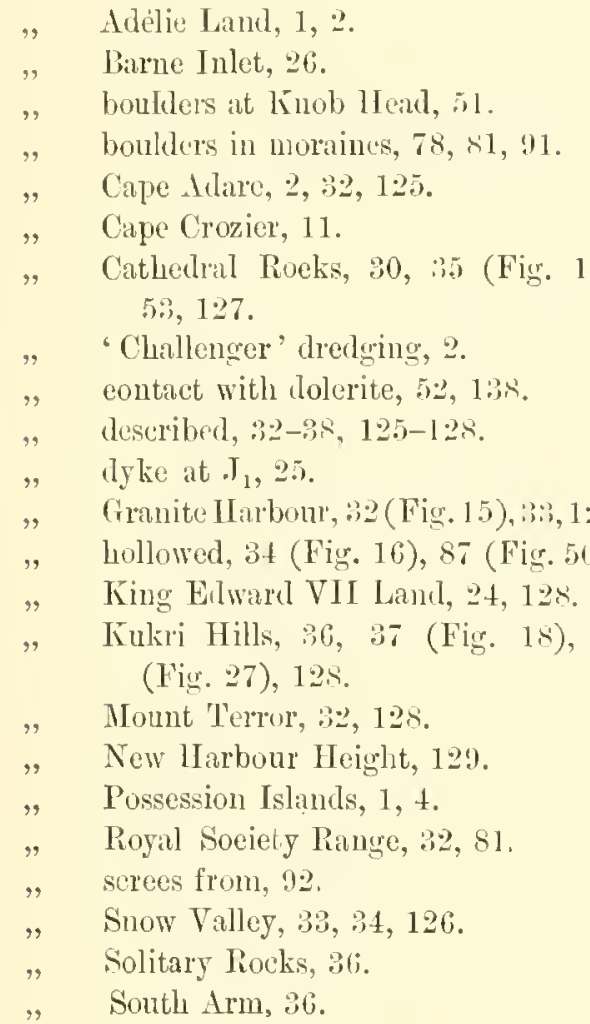

Grunite, Southern Foothills, 25, 126.

Granite Harbour, see lig. 15 (p. 82).

$$
\begin{aligned}
& \text {, } 54 . \\
& \text { " busalt-dykes, } 33 \text {. } \\
& \text {, described, } 3 \%, 3 \% \text {. } \\
& \text { dolerite, } 32,83,54,126,138 . \\
& \text {, gabbro, 126. } \\
& \text {, glaciers, } 71 \text {. } \\
& \text {, grneiss, } 126 . \\
& \text { " granites, } 32,39,125,126 \text {. } \\
& \text { iee-fringe, } 61 \text {. } \\
& \text { " micaceous sehist, } 185 \text {. } \\
& \text {, pegmatite, } 126 \text {. } \\
& \text {, perched bloeks, } 94 . \\
& \text { piedmont, } 66 \text {. } \\
& \text {, quartz-purphyries, } 126 \text {. } \\
& \text { ". sandstone, } 126 .
\end{aligned}
$$

Graphite, in crystalline limestones, 124.

Gravels, Haequarie Island, 96.

$$
\text { , } 89 \text { (Fig. 5\%). }
$$

Gräreneck, hornblende-liabase, anal, 105.

Great Lee Barrier, sre Barrier.

Grent Rift Valley, Atlantic type of rolcanic rocks,

$$
122 .
$$

Gicenland, glaciers, 69.

$$
\begin{aligned}
& \Rightarrow \quad \text { gneiss, 124, 125. } \\
& , \quad \text { ice-cap, 65. } \\
& , \quad \text { inland-iee, 64. }
\end{aligned}
$$

Gregory, J. W., ice-sheet, ref., 6r.

$$
\begin{aligned}
& \text { lienytes from Mt. Kenyil, ref, } 111 . \\
& \text { Pacific Coast of South Victoria } \\
& \text { Land, 122. } \\
& \text { up-thrust of morainic material, } \\
& \text { ref., s2. } \\
& \text { volcanoes of South Victoria Land, } \\
& \text { ref., 14, } 39 .
\end{aligned}
$$

Grit, Finger Mountain, 1:24, $1: 34$.

Gullies, in sindstones at $x, 92$.

II (hill) see Mapl and Sections (Plate VII), and also New Iarbonr 11 eight.

$$
\text { " gneiss, } 29,30 \text {. }
$$

$\mathrm{II}_{2}$ (hill), see Map, 30 .

$\mathrm{h}_{4}$ (hill), see MLip, 30 .

Inddington (Mount), 7.

Haggitt's Pillar, 3.

Hail, 83.

Inamberg, A., struetme of sea-iec, ref., 55.

Itinneyletscher, 64 .

Hanging glaciers, 64, 7\%.

IIanging valleys, 37, 72, 73 .

Ilarbour Ileirhts, see Plate II.

$$
, 21 \text {. }
$$


Harhonr Hoights, basult, 12, 1:, 101, 106, 108.

$$
\begin{array}{ll}
, & \text { bonds, 12, 106. } \\
" & \text { leseriberl, 12. } \\
. & \text { limburgite, } 12,18,107 . \\
., & \text { nodules in basalt, 107, } 108 .
\end{array}
$$

Ifurker, A., igneons rocks of Skye, ref., 136.

IIiirtlugen, hornhlende-bisalt, anal., 10.\%.

Iayes l'eninsula, local icc-ca]1. 6:3.

Hector, lnasits of Iuekland Islands, ref., 96.

Heim, 1., air in orlacicr-ice, ref., 68 .

$$
\text { ,. iceliergs, ruf., } 73 .
$$

, ice-eracks, ref., 83.

., nomenclature of land-ice, ref., 63, 64, 67.

., temperature of ice, ref., 86.

Ileldbnro, limbnrite. 121 .

11 essose, li2s.

Hochlambris, 63.

Horlgson, T. Y., Glauher Salt, 91.

. iec-crystils on fishing line, 5.j

(Fiy. 299$)$.

rocks of Inneeessible Islund, 16.

" rocks from Sultan's Head, 11.

", rocks from V-Cliffs Horslack, 10.

" tuffs of 'Turk's Il "ud, !).

IIolland, 'T. II., "augite-diorite" of Southern India, ref., 1:36.

In llowed granite boudders, sen franite (lollowed).

Ilorizontal structure, ut ('ine Adarr, 18.

$$
\begin{aligned}
& \text {, Inland Futs, l:;. }
\end{aligned}
$$

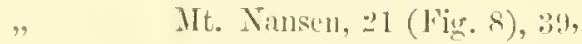

$$
\begin{aligned}
& \text { nt. }
\end{aligned}
$$

Horn (Cape), 7.

IIornblende, in banalkites, 35, 1:31-1:33.

,$\quad$ in altered delerite, 128 .

., in Insalts, 102, 104, 122.

, in ("m) intonites, 129.

, in rionite, $127,12 \times$.

, in gneiss, 1:21, 1:25.

, in granite, $12(i$.

, in kersintites, 1:30, 131.

, $\quad$ in nodnles in hasalts, 107, 111

" in phonolites, 116 .

, in tomplytes. 11\%.11\%, 12\%.

Ilomblemle-lasalt, analyses, $10:$.

$$
\text { , texcribed, 102-101. See also }
$$
lisisalts.

"Ilornblende-dialnse", Gräreneck, anal., 105. Ilormblemele-psemelonuorphs, sep P'sendomor ples.

Ilornblende-schist, 1:25.

llomblende-tratelytes, Otservation Hill, 117-119. Sim also 'Triachyotes (jhonolitio).
IIorseshoe Bay, basalts, 106, 120.

Iorseshoe Monnt, 22.

Huggins (Mount), Fig. 9 (1. 2:3).

Hummoeks, 57, 59, 82, 85.

II undsliopf, nepheline-basanite, 121.

If urricane Pidge, galllro, anal., 1:7.

Hnt Point, see Plate II and Firss. 32 (p. 5s), 3.) (1).61).

, 12.

, cracks in se 1 -ice, 59.

, jee-foot, 61 .

, incrustation of Glauber Salt, 91.

, water-holes at, 58 .

Ifutton Cliffs, basalt-tuff, 11, 104, 110.

Hutton, F. Wr., voleanoes of Auckland, ref., 12.

Ilyalopilitic structure, in basalts, 10 t.

Iybrid rock, Granite Harbour, 138, 189, and Plite X, Fig. 6.

Ifyland, .J. S., bibliography of hornblende-psendomorplis, ref., 103.

IIypersthene, in diorite, 127.

,$\quad$ in olivine-norlnle, $10 \mathrm{~s}$.

Ice, depressed by suow, 85 (Fig. 49).

, retreating, 9t, 99.

, of glaeier-iee fringes, 62 .

, in Ross Sea area, 9!.

Sre also Sen-iec, Pinmacled ice, Lamil-ice, etc.

Lee-ation, in denndation, 98, 94, 9:).

Ice-burrier, see Barrier.

lee-belt, McMnrdo Sound, 66 .

Ieeberg, tilted, Fig. 40 (ए. 7 1).

Iceljergs, 64, 73-75, 94.

, Balleny Islands, 74.

„ Blue Glacier, $7:, 94$.

, Cape Adille, 75.

, distribution, 75.

" King Edward VII Land, 2 t, 75.

," melting of, 75 .

, Ross Island, 6.).

, Ross Piedmont, 7t.

, size of, 75 .

$"$ Sonth Vietoria Iand, 7:․ 75.

Ice-eaps, 63. 6.5, 99.

Ice-cerystials, $8: 3$.

, on fishing line, 55 (Fing. 29).

Icc-falls, Ferrar Glacier, $69,83$.

, Mrount Lrebus, 6.5.

Iec-lickd, 60 .

lec-llowers, sis.

I ce-foot, Arctic licerions, 61 .

,. Grimite Ilarbour, 61. 
Icc-foot, Hut Point, Fig. 35 (p. 61).

Wood Bay, Fig. 37 (p. 65).

Icc-fringe, Castle Ruck, Fig. 36 (p. fil).

,$\quad$ conservative artion of, $61,6 i=$.

lec-gatuge, 59.

lee-sheet, 6:3, 6.t.

Ice-stals, 6.t, 99.

, agglading, not excuvating valleys, 93.

, cuglacial matter in, 78 .

" Southern Foothills, 71, 78, Plate VI, and Map.

Ice-streams, (i3, 65, 74.

Ice-tongues, in Ercbus Bay, 14.

North Fork, 72 (Fig. 39).

Ice-without-grain, at Kinob IIcad, 8.2 , and lig. $42(p .77)$.

Iddings, J. P., shoshonite, ref., 180.

, classification of rocks, ref., 120 .

, gabbro of 1 Iurricane Ridge, ref., 127 .

Ilmenite, in hasalts, 104 .

. in dolerites, 130 .

Inacessible Island, basalt, 16, 106.

$\begin{array}{ll}, & \text { deseribed, } 16 . \\ \text { Glanber Sult, } 91 . \\ \text { Phonolitic trachytes, 16, 11t, } \\ & 115 . \\ & \text { trachydolerite, } 16 .\end{array}$

Inclusions, coarse-grained, in basalts, $12,1: 106-$ 109.

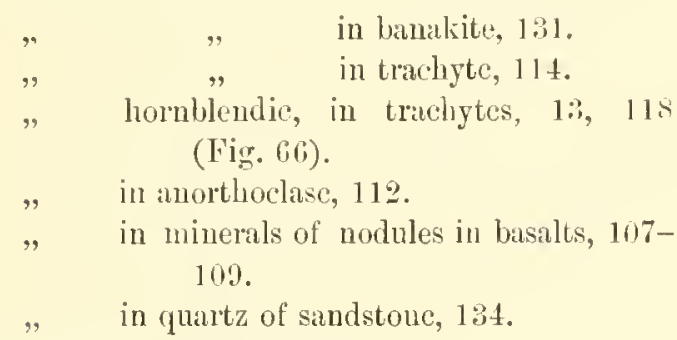

India, charnockites, $1: 5$.

Inland Forts, see Fig. 20 (p. 42).

" corric-glaciers, $7:, 9:, 94$.

" dolerite and sandstone, 40, $42-44,50$, 5:3, 1:3, 139, and Plate X, Fig. :

" fossils (?) in sandstone, 43,48 .

, moraines, 73.

Inlamd-ice, 39, 4:2, 54, $6.8,64,69,70,84,99$.

Inlets, 64 .

Ishawoua Canyon, banakite, anal., 132.

Ivory (ilacier, spitzhergen, Ts.

$\mathrm{J}_{1}$ (hill), see Mapl and Sections (Plate V'II) and

Figs. 11 (p. 26), 54 (p. 90).

, crevisses in Bluc Gilacier, 71.
$\mathbf{J}_{1}$ (hill), crystalline limestone, $25,26$.

, granitic dylic, 25.

Jeussen, Captain, rucks from Possession Islant, 4.

Johnson, Wr. D.. "pilnckine" of rock-masses, ref., 94.

Joints, in granite, s::3.

Jones (Cape), Fig. T (1). 19).

Judd, J. W., Tol(anues, ref., 95.

Karajak ice-strcam, 7R.

Kícunar (P. 0.), 40 .

kienya (10mont), kenytes, 1112, 111-118, 110.

Kenyte, Cape Rogds, 3, 111-113. 182. and Plate VIII, Fig. $\therefore$.

,$\quad$ anal., $113,119-12.2$.

" islands in Erehns Bay, 14, 16, 110-113.

" moraine in Discovery Gulf, 118.

, Monnt Erebus, $102,123,1+0$.

, Mount Ḱellya, 102, 111, 112,140 .

, ,,$\quad$ anlal., 113.

, Momnt Kilimandjaro, 102, 111, $112,140$.

, ,, amal., 113.

, Skltary, !, 10, 111.

, T'ent Island. 16, 111.

, Turtle Bark Islatud, 14, 110 (Fig. 601), 111 (Fig. (19).

wind-effect on, 8. .

Kenytes, described, 110-113.

liersantite, dyke at $\mathrm{E}_{4}, 84,1: 1$.

, Northern Fouthils, $2 \pi, 130$, and Plate

IX, Fig. t.

", anil., 130.

,$\quad$ Stengerts, anal., 180.

Kersantites, described, $130,131$.

Kibo, analysis of kenste, $113,121$.

Kilimand jaro (Mount), kenytes, 102, 111-11:, 140 . King Edward VII Land, Fig. 10 (1). 24).

\begin{tabular}{|c|c|c|}
\hline 9 & " & 7 \\
\hline & "' & described, 24 . \\
\hline & $"$ & icebergs, 24,75 . \\
\hline & $"$ & $\begin{array}{c}\text { lebbles of griulte, } \\
\text { ete, } 24,128,13 .\end{array}$ \\
\hline
\end{tabular}

Kinob Head Momtain $\left(B_{9}\right)$, see Plates $Y$, V'II, and Figs. 14 (р. 20$), 20$ (1. 52), 28 (1.54), 41 (p. 76$), 4:(p .77)$.

$37,69$.

$" \quad$ " $" \quad$ buniders of granite, ete., is, $51,76,77$.

dolerite and sundstone, 40 , $41 ;, 47,49,51-53,13 \%$.

frozen pond, s:. 


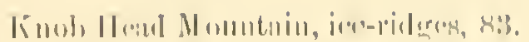

\begin{tabular}{|c|c|c|}
\hline & " & 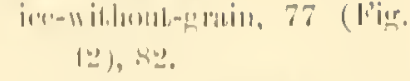 \\
\hline & ", & mumimes, 76 (liger. 11), 78. \\
\hline & " & 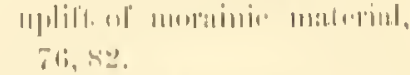 \\
\hline
\end{tabular}

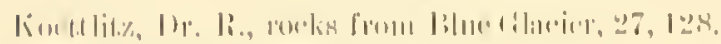

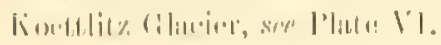

$$
\begin{aligned}
& \text {, } 20,71
\end{aligned}
$$

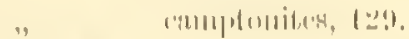

Lingulimnil, !):3.

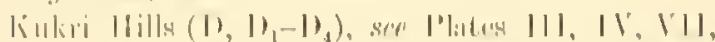

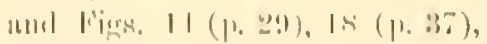
$27.7 .53)$.

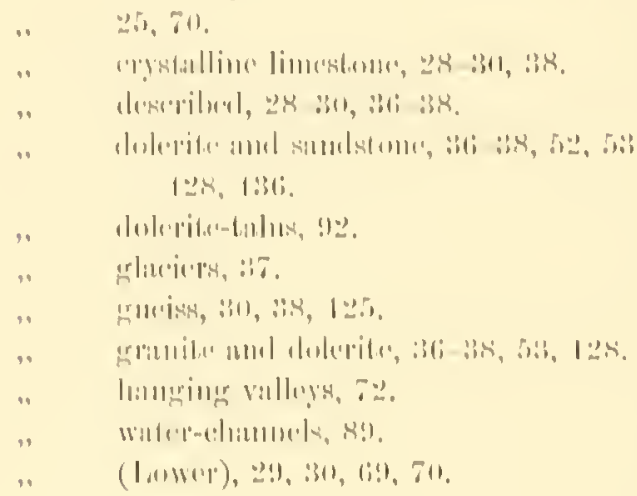

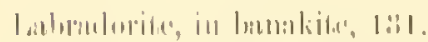

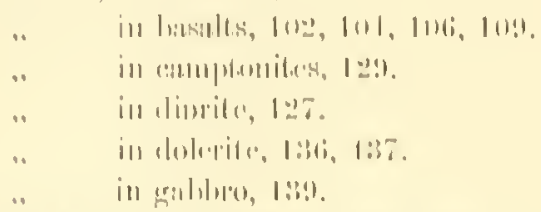

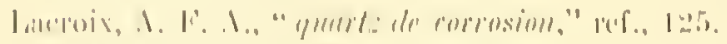

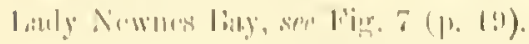

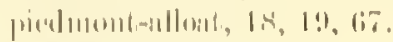

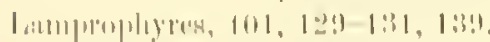

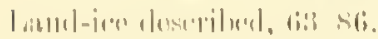

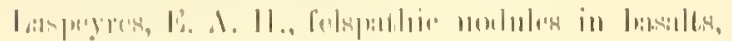
$101 ., 1117$.

I mombliluse, I:010.

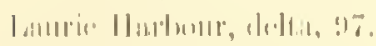

lammilaser, 1:31).

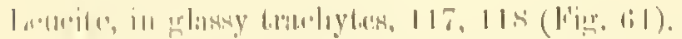
in linllyle, $111-113$.

la

l.imlullerill, 1011, 1 16.

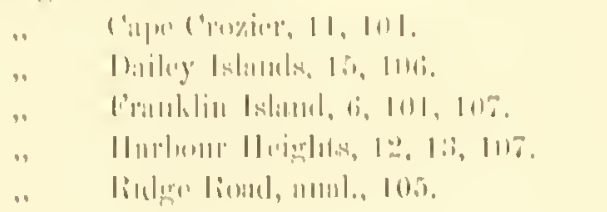

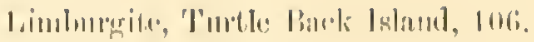
limilmlense, 1:01.

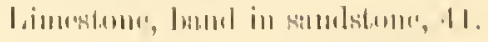

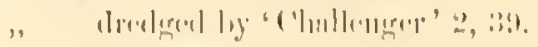

$$
\begin{aligned}
& \text { " (rrystallino), 101, 1:3!. }
\end{aligned}
$$

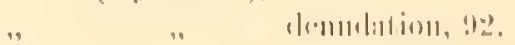

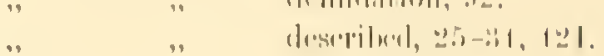

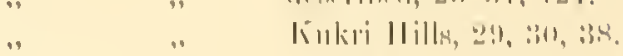

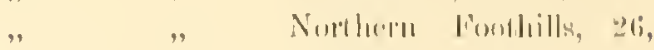

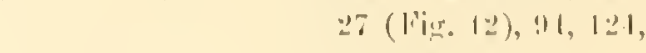

$$
\begin{aligned}
& \text { 1:30, 1:33. }
\end{aligned}
$$

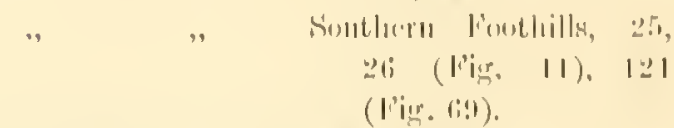

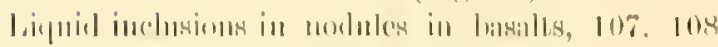
(likg. lin).

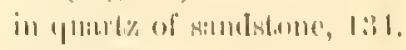

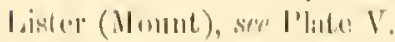

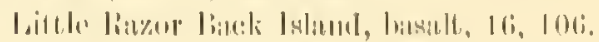

$$
\begin{aligned}
& \text { " } \quad \text { deservilurl, } 16 .
\end{aligned}
$$

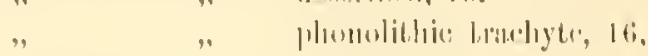

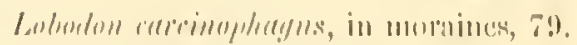

latis

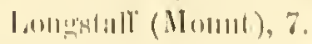

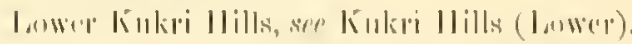
I.

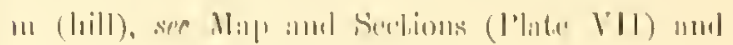
Fig. I I (1). $2: 1)$.

" roystallime limestome, :?!

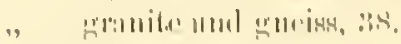

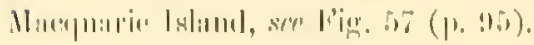

$$
\begin{aligned}
& \text {. } \quad 1 \%, 101 .
\end{aligned}
$$

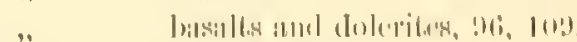

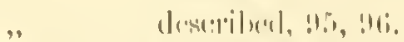

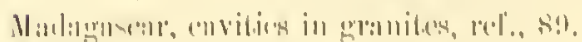

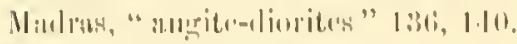

Malistoin, phomolite, 1ㄹ.

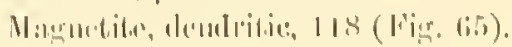

$$
\begin{aligned}
& \text {. in lomalitite, 131. }
\end{aligned}
$$

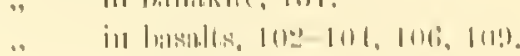

$$
\begin{aligned}
& \text {.. in luseslt-111)!, 10!1, 110. }
\end{aligned}
$$

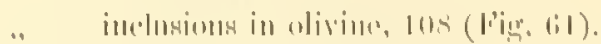

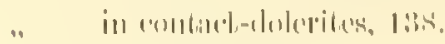

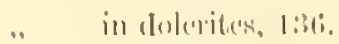

$$
\begin{aligned}
& \text { ". in plomolitu, } 116 .
\end{aligned}
$$

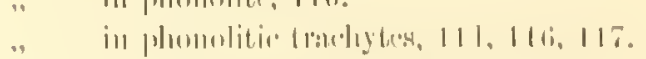

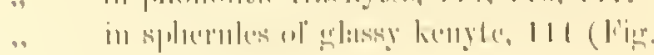

$$
\begin{aligned}
& \text { (iii). }
\end{aligned}
$$

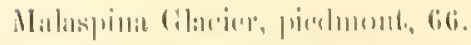

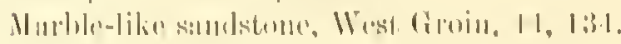




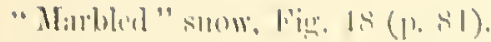

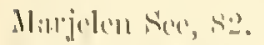

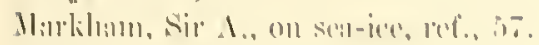

Me(Y)mick, 1)r. li... 21.

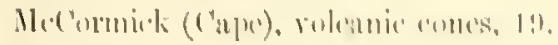

Me:Mrurles simml, 15, 8.

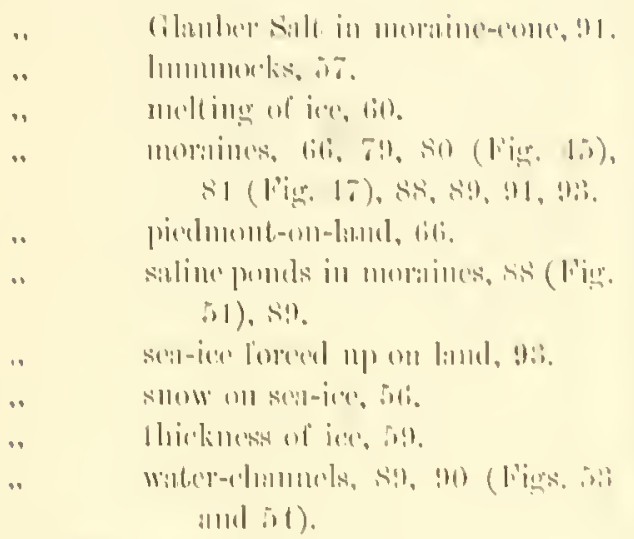

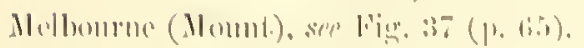

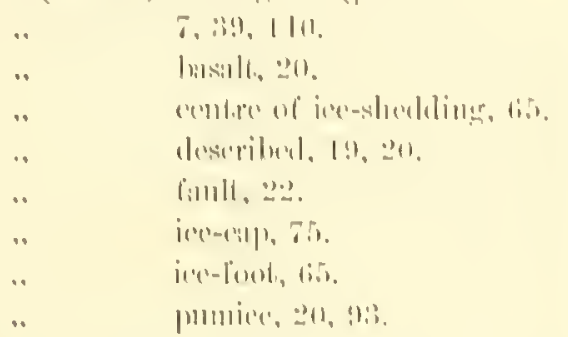

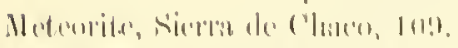

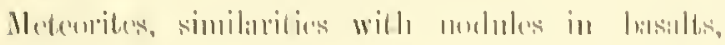
$10 \%, 10 ! 1$.

Misklise, 1:0.

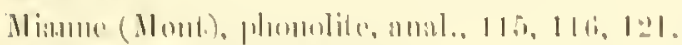

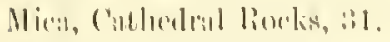

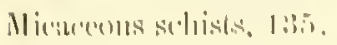

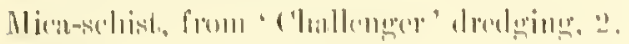

Mlemeline, in granite, 12s,

$$
\text { .. in git. 1:21, 1:31. }
$$

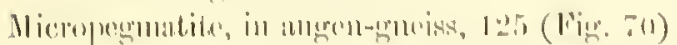

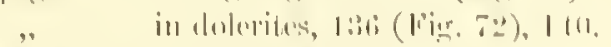

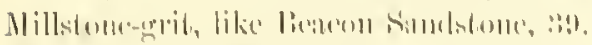

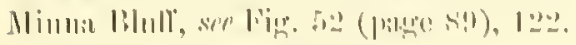

$$
\begin{aligned}
& \text {. bisilli, 21, lok, } \\
& \text {.. deseriberl, 201, 21. }
\end{aligned}
$$

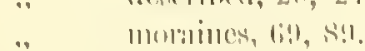

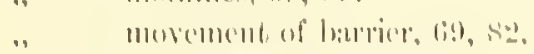

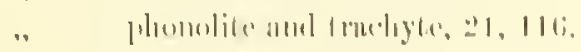

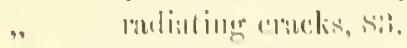

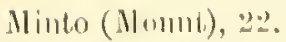

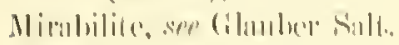

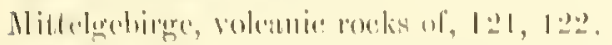

"Mole," I:il.

VOI. I.

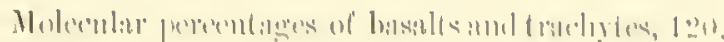

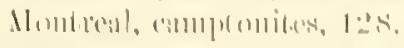

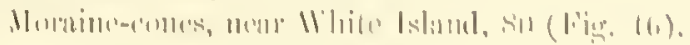

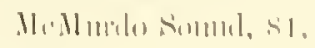

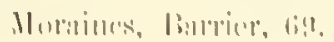

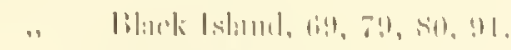

. limon lslimel, li.

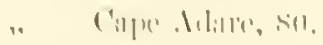

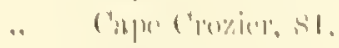

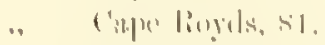

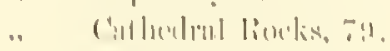

. dulerites iu, sis, s1.

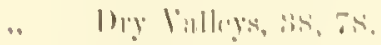

. linal link, os.

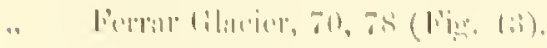

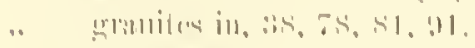

. IIill 11. 1.75

. Inlamel linte. 6 is.

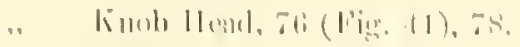

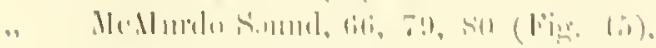

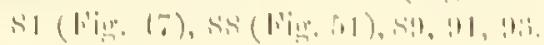

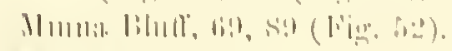

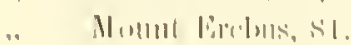

.. Mlomit 'l'mpor, sil.

.. Ninllo link, Ts.

. re-sortod, sion.

.. Sikn:1ry, !!

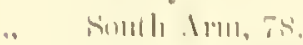

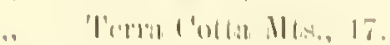

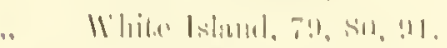

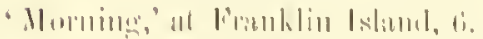

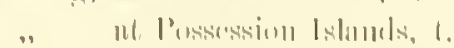

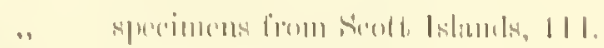

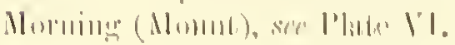

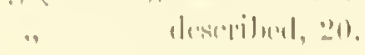

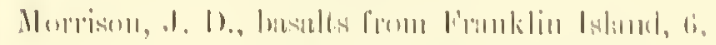

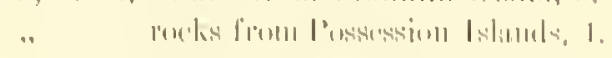

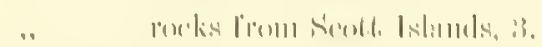

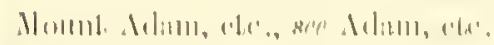

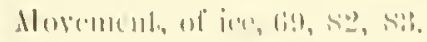

Motstume, hrolides in sumkstume, 11.

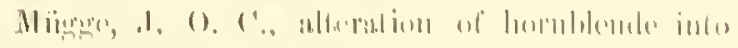
oliviur, met., 111.

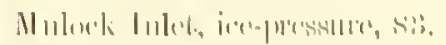

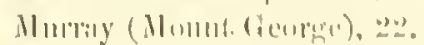

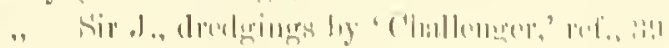

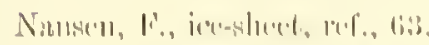

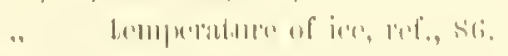

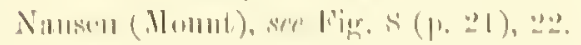

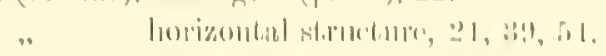

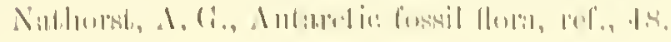


Nepheline, in basalts. 106 .

. in kenytes, 11?.

, in phonolites, 116 .

". in phonolitic trachytes, 11.1-116, 119.

., Litchtield, imal., 11:.

Neumayer (Monnt), piedmont-afloat, 67.

New Harbom Ileight (H), 28 (Fig. 1:3), 29, 30. " camptonite and granite, $1: 2$ ?

New Mount $\left(B_{5}\right)$, see Map and l'lates T, VH.

New 7eeland, 95, 9).

$$
, \quad \text { glaciers, } 7 \AA .
$$

Nodule, coarlse-grainul, in basalts, $12,1 \%, 106-$ 109), 140, and Plate VIJI, Fig. :

Nodules, ferruginons, in sandstone, 11 .

Nordenskiöld Piedmont, 67 .

'Norm' of lanakite, 183.

soundings, 94.

., of losalts and trachytes, 120.

.. of diorite, 128 .

, of dolerite, $1: 37$.

" of kersantite, 130 .

Nortl (Cape), 21, 22.

$$
\begin{aligned}
& , \quad \text { gracicrs, } 71 . \\
& , \quad \text { pyramidal peaks, 2:. }
\end{aligned}
$$

North Fork, sce Scetions (Plate VII), and Fig. 39

$$
\text { (p. } 72) \text {. }
$$$$
\text { , } 28,69,70 \text {. }
$$$$
\text { , ice-tongnes, } 72 .
$$$$
\text { , } \quad \text { moraine, } 78 \text {. }
$$

Forthern Foothills $\left(\mathrm{G}, \mathrm{G}_{1}, \mathrm{G}_{2}, \mathrm{G}_{4}\right)$, see Plate IV and Fig. $14(\mathrm{p}, 29)$.

$29,30,39,66,69,70,94$. banakitcs, 35, 131, 13:, and I'late IX, Fig. 6. lonakites, anal., 1:3:. crystalline limestoncs, 26 , 27 (Fig. 12), 9!, 12 !, 130 , $13: 3$.

$\Rightarrow \quad$ described, 26-28.
$\Rightarrow \quad$ kersilntites, 27, 190, and Plate Id, Fig. $t$. perclierl blocks, !) t.

North-We:t Mountaiu (C), see Map.

North-west Nunatilis, 69.

Norway, rlumb-[rorphyrices, 111, 110.

Nintatiks, +4!, 6.t, (i!).

Olelisk $\left(\mathrm{C}_{3}\right)$, see Sections (Plate TIT) and Figr. 39 (1\%. $7 \ddot{\prime \prime})$.

$, \quad 5: 3$.

(O) scrition Hill, se" l"late II.

$$
\text { , } 12,123 .
$$

Ohservation Ilill, basalt, 13.

$$
\begin{aligned}
& \text {,. describer, 1:, } 1.4 . \\
& \text { " trachytes, } 13, \quad 117-120, \text { amk } \\
& \text { Plate VIII, Fin. } 6 \\
& \text { wind-action, 87, 8s. }
\end{aligned}
$$

Oligoclas: in banakite, 193.

$$
\begin{aligned}
& . \quad \text { in camptonite, } 12 ! . \\
& " \quad \text { in gnciss, } 121,125 . \\
& " \quad \text { in granite, } 126 . \\
& . \quad \text { in kersantite, } 130 .
\end{aligned}
$$

Olivinc in basalt-tuff, 109, 110.

, in basalts, $102,104,106,10 ! 1,1: 2$.

, in gablio, 136;, 139.

"in kenytes, $111,11 \%$.

.. in norlules in basalts, 107-109.

, in phonolitic trachytes, $111,122$.

" with magnetite-inclnsions, 10s (Fig. (61), $10 ?$.

Olivine-basalts, deseribed, $10 \mathrm{L-106}$; see also Basalts. Olivine-nodules, in lasilt of Frankliu Island, 6.

$$
\begin{aligned}
& \Rightarrow \quad \text { in limburgite of Cape Crozier, } 11 . \\
& , \quad \text { origin of, ref., 109. } \\
& , \quad \text { Turtle Back Island, 11, } 108
\end{aligned}
$$
(Fig. 60).

Orthoclise in banakite, $1: 31$.

$$
\begin{aligned}
& , \quad \text { in gnciss, } 124,125 . \\
& \text { in granite, } 32,34,126 . \\
& \text { in kersantite, 130. } \\
& ., \quad \text { in phonolite, } 116 .
\end{aligned}
$$

Orthogneiss, 124, 189.

Osann, 1., classification of rocks, 120, 121.

, formula of rocks, see Formule.

Pacilic Occan, roleanoes encircling, 12.2.

I'acifie type of rolcanic rocks, 12:, 140.

Pack-ice, 56 (Fig. 80), 57 (Fig. 81), 59, 60.

, Wood Bay, 65 (Figr. 37 ).

Paligonite-tuffs, $1, t, 5,11,12,109,110$.

Pancake-iec, 57.

Piutclleria, anorthoclase, 112.

l'eat, Auckland Islands, 9\%.

Peat-bogs, Maequarie Island, 96.

Pelbles in Bereon Sandstone, +1, 1:it.

Peeten, shell in gravel on Ferrar (tacied. 7!).

Peormatite, Cathedral livelss, $; 1$.

,. Granite Itarhonr, 1?6.

Percherl blocks, !) 1.

Petrographical provinee, 12:, 1 to.

Philippi, L., Ilscription of Ganssberer, l'ef., 140.

P'llogopite in crystalline linestone, 121 .

Phomolite, likek Islinml, II6, and l'late VIII, ligig. 5. 


\section{INHES.}

Phonolite, Bull C'liff, anal., 121.

$" \quad$ Cape Adire, 116.

" Minna liluff, $21,116$.

Mont Mimune, anal., 11\%, 116, 121.

. Possession Islands, 4.

Phono.ites, leseribed, 116.

. in 'Sonthern C'russ' collections, 102.

Phonolitic trachytes, see Trachytes.

Picotite, in nodule in basalt, 108.

., in olivine of basalt, $10 t$.

Piedmont-glaciers, 68, 6.7-69, 74, 99.

Piedmont-iee, strmetme of, $6 \pi, 6 \mathrm{x}$.

Piedmonts-afloat, 68, 67-69, 94.

.. icebergs from, 74 .

, Lady Nernes Bay, 18, 19, 6\%.

, Sturge Island. $\therefore$.

Piedmonts-gground, $6 ., 6,6,67$.

$$
\begin{array}{ll}
, & \text { Comlman Island, } 5 . \\
, & \text { iecbergs from, } 7 . \\
, & \text { Stmge Island, } 9 .
\end{array}
$$

Pilotaxitie structure, in basilts, 104.

P'innarled ice, 15, 80, 90 .

"Pipe" of diorite, 127 .

Pirsson, L. T., classification of rocks, ref., 120 .

I'lant-remains, see Fossil.

Platenu of Fonth Tictoria I and, ״1, 98.

Plateatu-doleritc, Ferrar (i)acier, 40.

Plitenn-features, 24, 51,99 .

$$
\begin{aligned}
& \text {, Royal Socicty Range, 2:; (Fig. 9), } \\
& 39,5 \% . \\
& \text { Mount Nansen, 21 (Fig. s). } \\
& \text { Sece also Horizontal Strueture. }
\end{aligned}
$$

"Plucking" of rock-masses, 91.

Polar ice-eap), (is.

Possession Islands, see Fig. :2 (p. t).

$$
\begin{array}{ll}
. & 1,7 . \\
, & \text { described, }, 5,5 . \\
, & \text { stranded moraines, }-1 .
\end{array}
$$

Pothules in granite, s!).

Pram Point, hummocks, 59, s.2.

Prinec Albert MIts., deseribed, 22:.

$$
\begin{array}{ll}
, & \text { glaciers, 69. } \\
, & \text { iee-slopes, } 66 . \\
, & \text { ice-streams, } 7 \text { t. } \\
, & \text { inland-ice, } 6 t .
\end{array}
$$

I'rior, G. 'T., 100.

analysis of kengte from Mt. Kenya, ref., 118.

Atlantie and Paeifie types of rolcanie roeks, ref., 10ㅇ, $1 \geq 2.2$.

bisilt of Franklin skland, ref., 1, 6 , 107.
Prior, C. T., basalt of Mount Melbourue, ref., 20. basall of Mount 'T'error", ref., 10.

, basaltie dylies alt Cape Adare, ref., 17.

" basalts from Anekland Islands, lef.

"96, 109.

" dredgings of 'Challenger;' ref., :39.

. Glauber Salt, aual., 91."

, roeks of Coulman Island, ref., 5.

.. roeks of Great Rift Talley, ref., 116 , $12 \cdots$.

. rucks from Possession Istands, ref., 1.

. Report on the Pock-speeinens, 101142.

, 'Southern ('ross' rock-collection, ref., 2, 101, 102.

Psendomorplss, after hormblende, 102, 10: (Fig. 59), 104 .

Pnuniee, Mount Melbourne, 20, 9:3.

Pyramidal peaks, Admiralty Range, $5 t$.

Pyroxene-granulite, Madras, 186, 140.

Quartz, angular fragments in sandstone, fi.

,$\quad$ in liorite, 127.

,$\quad$ in clolerite, $1: 36$.

" in gneiss, 124, 125.

" foreign inclusions in camptonite, 12\%.

"Quartz de corrosion," in guciss, 125.

Quantz-grains, in Beaeon Simdstone, 13t (Fig.71).

Quartz-grit, Finger Momntain, 1*t, 1:3t.

., in dredge off Conlman Island, 34.

, King Edward VII Land, 1,ij.

Quartz-porphyries, 139.

$$
\begin{array}{ll}
. & \text { Cathedral Rocks, } 81 . \\
, & \text { Granite Harbour, } 126 .
\end{array}
$$

Qnartz-schist, pebble in sandstone, $41,1: ;$ t.

Quartz-reins, in granite of Snow Talley, :34.

Quartaite, pebbles in sandstone, 41 .

, seans in Bencon Sindstone, 1:H.

. Terma Cotta Mts., 47.

Raisud beach ?, Macquarie Island, 95.

Rizor Bick Island, anticline, 123.

$$
\begin{array}{ll}
, & \text { basalt, } 16 . \\
, & \text { described, } 16 .
\end{array}
$$

lie-eemented giciers, (it.

R.clicf ships, (60 (Fig.: : :4).

Report on Field-geology, 1-99.

$$
\begin{aligned}
& \text {, Plant-lemains, tri. } \\
& \text {, } \quad \text { Rock-speeinens, 101-142. }
\end{aligned}
$$

Re-surted moraines, si.

Rhomb-7rorpliyls, 10:3, 110-11n, $1 \pm 0$ (see also Kenyte).

Rildge Road, limburgite, anal., 105. 
lielecelite, in plionolitic traehyti, 116.

lift Valley, phonolitic roeks, 116.

liink, II., land-ice, ref., 6:i, 6i.

$$
\because \text { sea-iee, ref., } \vdots \text {. }
$$

Robertson bay, glaciurs, 71 .

$$
\begin{aligned}
& \text { slates, } 2 . \\
& \text { ralley, } 22 .
\end{aligned}
$$

Roches moutonnées, "1t.

linetedebris, at II inter Quarters, 87 .

$$
\text { . englacial, 76, 77. }
$$

liock-flour, deposit in Ross Sien, 14.

Jiosenbuseh, II., trachydolerite grouj, 10?, $113,117$. lioss, Sir .Tames Clitke, 1, 9 t.

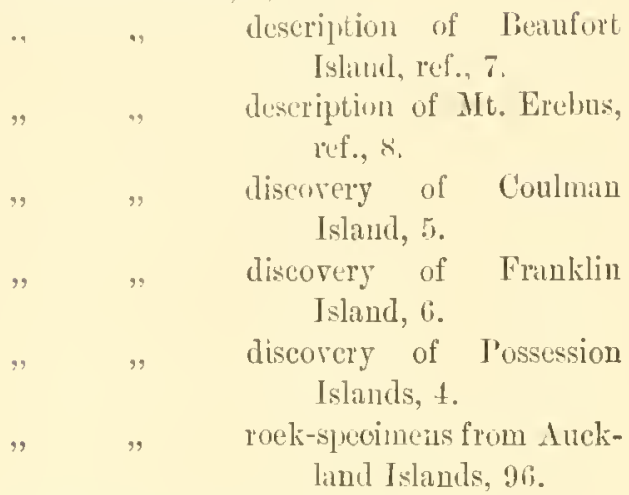

Ross A lehipelago, 9s, 101, 1 to.

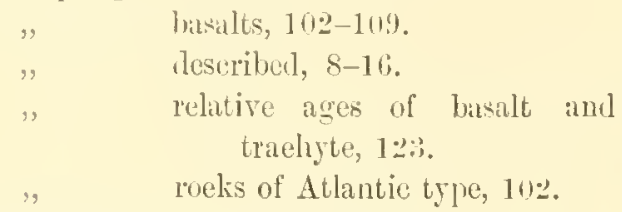

lioss Expedition, at Auekland Islands, 10 \%.

Ross Great Jee Farrier, see Banter.

lioss IIarbour, 96, 97 (Fig. 58).

lioss Istand, 10, 13, 1 t, 89, :12.

$$
\begin{aligned}
& \text {, lisilt-tufls, } 109 . \\
& \text {, describerl, it. } \\
& \text {., iceloergs, } 65 . \\
& \text {. suow-eovered motmatims, 6.5. } \\
& \text { " soundings, } 8 .
\end{aligned}
$$

Tioss l'iedmont, see Jiulrier.

lioss Q Quachant, 1.

Russ hea, 1, 17 (liug. 6), 6.t, 9. tranites drodged up, : : $: 2$.

". rock-flour deposit, "4. thiekness of flocs, 5.7 .

Iiound IIt. $\left(\mathrm{C}_{1}\right)$, see lig. 20 (11. 42). dolerite and simdscone, t5. glacier, 73.

Royul Soeiety liunge, spe l'lates 11 I and VII, and

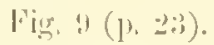
(31, : $: 3 ;-35,69,711,7: 3,98$.
Royal Society Range, a faulted erust-bloek, 53.

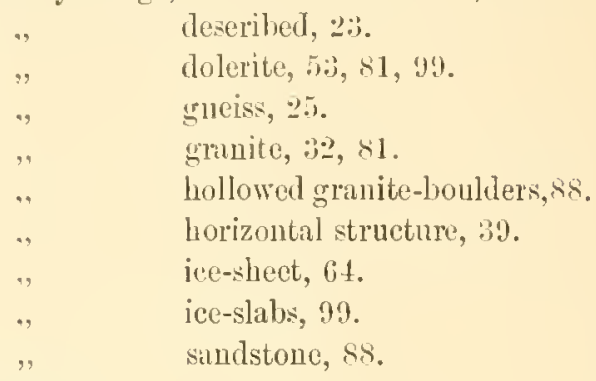

Rowe Island, :.

Royds (Cape), coustal ice-fringe, 6i.

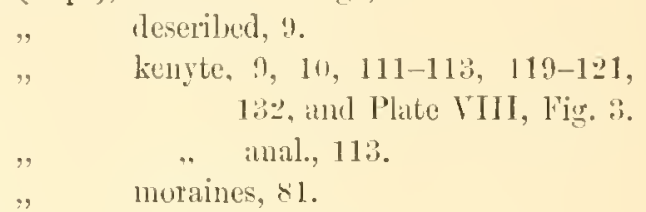

Thoyds, Lient. C. WT. T., sonth-cast jommey, 67.

$$
\text { ,, pressure-ridges, } 82 .
$$

Russell, 1I. C., size of icebergs, ref., 75 .

Russell, J. C., ice-streams, ref., 65.

$$
, \quad \text { piedmont-glaeiers, ref., } 68,66,6 \pi \text {. }
$$

Tutile, in sandstone, 184.

Siljine (Mount), 21.

Saline ponds, in moraines, 8 ( Vigr. 51).

Salinity, of sea-iee, $55,56$.

Salt, conecntration of, in pools, 56 .

, in sea-ice, 56 .

Sands, 89, 90 .

, Iamie Harbour, 97.

, Macquarie Islaud, 95.

Sutulstone, 40, 5i, 92, 189.

, area and thickness, 5:3, 51 .

, at $B_{1}, 40-42,45,48-50$.

, Beacon Heights, 46 .

" boulders in moraines, 78 .

. Cape Crozier, 11.

, Cathedral Rocks, 30, 35.

.. contaet with dolerite, 49-5 t, 138.

, Depôt Nunatak, 40, 11

. deserilued, 39-5 t, 134 .

.. dolerite-sill in, 40 (Fig. 19).

., dredged l.y 'Challenger,' 2, 39.

" Dry Valleys, 4., 46.

., earth-morements in, 99.

, Finger Mountain, 4t, 45 (Figg. 22), 50, 51.

fossil plant-remains in, 10-43, 16-18, $99,139$.

frost-inction, 92 .

, (irmite lIarbonr, 126. 
Sandstone, incInsions in basalt, 105.

, Inland Forts, $40,42-44,50,53$.

, Kinob Head Mt., 47, 51, 52 .

" Kukni Hills, 52.

,. stalagmitic, $t$ t, $1: t$.

"T'erra Cotta Mits., 47.

See also Beacon Sindstone.

Sandy Rity, 97.

Staner, G. A., trachydolerite from Campanario, ref., 119.

'Scars,' Anckland Islands, 96.

Schanb, L., twinning of angite, ref., $1: 37$.

Sclist, Barne Inlet, 26 .

, Blue Glacier, 27.

, Gramite Harbour, 32.

" (horublende), 29, 125.

, (micaccous), described, $1: 35$.

Schotield, J. A., rocks from Possession Islands, 4. Scott, C'apt. R. F., 6i7, 88.

$$
\begin{array}{ll}
" & \text { Gruat Ice Barrier, 67-69. } \\
, & \text { "inlets," 6t. } \\
" & \text { journey sonth, } 24 . \\
" & \text { journey west, } 21,39 . \\
\text { on North Fork, } 70 .
\end{array}
$$

Scott Islinds, 101, 1으, 140 .

, Phonolitic trachyte, $:, 114$

, deseribed, :3.

Scrope, G. P., Volcanoes, ref., 9, 95.

Sea-floor, composition of, 75 .

along Barrier, 94.

Sea-ice, described, 5i-60.

,, as transporting agent, 93.

, forced un on land, 93.

, removal of, 60 .

" thickness, 59.

Seal, renıains of, in moraines, 79.

Sections, at Cape Allare, 18.

, in sandstone at $B_{1}, 41$.

., ., at Inland Forts, 42 .

,., at Mest Groin, 4 .

Sedimentary rocks, 101, 134, 135.

Senfter, R., analysis of "diabase," 105.

Sequence of ermption, voleanic rocks, 12:\%.

Shackleton, tient. E. II., journey south, 24, 54.

Shale, 41, 18.5.

,, from 'Challenger' Aredging, 2, 39.

Shingle, Isamric IIarbon', 97.

Shore-ice, 61, 62.

, conservative effect of, 93. See also Ice-fringe.

Shoshonite, Beaverdam Creek, anaI., 130.

Shoshonose, 181, 182.
Shropshire, stiperstones, 134.

Sicra de Chaco, meteorite, 109.

Silica, in contact-dolerite, 138.

Sills of dolerite at Finger Mountain, 51.

silting of snow, st.

Sinai, weathering of granite, ref., 33.

Skelton, Lient. R. W., 100.

$$
\begin{array}{ll}
, & \text { granites from Snow Talley, } \\
& 8 t .
\end{array}
$$
13.9.

Sknatry described, 9.

, ice-streamr, 65.

, kenyte, 9, 10, 111.

, molalines, 9.

Skye, «rinophyre and gilboro, ref., 136.

Slate, Robertson Bay, …

Slaty rocks, described, 135.

Smceth, W. F., rocks from P'ossession Islands, ref., $t$.

Snow, accumulation of, 83-85.

" on sea-ice, 56 .

, thickness of, 57.

Snow-erystals, 8:?.

Snow-drifts, 56,84 .

Snow-duncs, 84.

$$
\text { " converted into ice, } 85 .
$$

Snow Talley, $7: 3$.

$$
\begin{aligned}
& , \quad \text { granites, } 83,2 t, 126 . \\
& ., \quad \text { glaciers, } 28,70 .
\end{aligned}
$$

Sodimm Sulphate, see Glauber Salt.

Solitary Rocks $\left(\mathrm{D}_{5}, \mathrm{D}_{5 \mathrm{t}}\right)$, see Plates V, III.

$$
\begin{aligned}
& \text { " } 69,70 \text {. } \\
& \text {, crevasses, } 70 \text {. } \\
& \text {, granite and dolerite, } 36 . \\
& \text { " up-thr'ust of morainic material, 8\%. }
\end{aligned}
$$

Solvsberorites of Norway, ref., 114.

Sommerlad, H., analysis of bisalt, 105.

Soundings, 8,91 .

South Arm, see Plates V nnd VII, and Figr. 28 (1. it).

$$
69,70 \text {. }
$$

", granite mil dolerite, 36.

". granites in moraiues, 38.

" ice-movement, $\$ 2$.

$$
\text { , moraines, } 7 \times \text {. }
$$

South Indian Ocean, 95.

Sonth Victoria Land, $2,11,39,57,69,74,8 \%, 87$, $89,91,94,95,98,123$.

bisement-1'ocks, 25-38, 101, $124-128,189$. 
Soutl Tictolia Land, const of Pacific trpe, 123, 140.

", $\quad$ cral)-cating seal, 79.

.. $\quad$ glaciers, $6: \%, 6 t, 94$.

, $\quad$ iceluerers, $7: 3,75$.

., $\quad$ ice-slabs, 64 .

$\because \quad$." islands off const of, $1-7,98$, 140.

, $\quad$.. limd-ice, 63.

,. $\quad$., mainland, 17-24.

., $\quad$ mountain-bclt, 61 .

,$\quad$, shore-ice, (1), 93.

South-west Arm, see Plate VII.

$$
, \quad 47,49,86 .
$$

- Southern Cross' Expedition, 101, $102,125$.

$$
\begin{array}{ccc}
, & \text { at Franklin Island, } 6 . \\
. & \text { basalts from Hount } \\
& \text { Terror, 10. } \\
. & \text { rock-cullcetion, 2. } \\
. & \text { rocks from Conlman } \\
& \text { Island, 5. }
\end{array}
$$

Southern Foothills, ser Plate VII.

$$
\begin{aligned}
& \text {. } \quad 71,81 \text {. } \\
& \text {, canptonite, } 129 . \\
& 124 . \\
& \begin{array}{ll}
. \quad & \text { granitc, } 25,120 . \\
\text { icc-shlus, } 78,78 .
\end{array}
\end{aligned}
$$$$
\text { , } \quad \text { crystalline limestonc, 25, 26, }
$$

Sphenc, in altered dolerite, $1 \geq 8$.

$$
\begin{array}{ll}
, \quad \text { in gabloro, } 126 \\
, \quad \text { in granite, } 126 . \\
, \quad \text { in phonolite, } 116 . \\
, \quad \text { in schist, } 135 . \\
, \quad \text { in trachyte, } 115 .
\end{array}
$$

Spheroidal structure, in trachyte, 13.

Sphernlitic structure, in rlolerite, 186, 140.

Spitzbergen, Ivory rilacier, is.

in glassy kengte, 111 (Fig. 68).

, . mp-thrust of morainic material, s2.

Sponge-spicules, sca-floor along Tirrvicr, 91.

"Stalagmitic" sandstonc, 4t, 134.

Stengerts, kersantite, anil]., 1:31).

Stiperstones, Sliropsline, 131.

Strain in ice of Ferral (G)acice, 83.

Strain-xhrlows in quartz of granite, 120 .

Stream-ice, 57.

Streng, 1., "hornh!eude-diabase," ref., 111..

Structure, of ice at Kuob Heal, s.2.

. of piedmont-ice, 67,68 .

$$
, \quad \text { of sea-ice, 5.). }
$$

Sturge Island, sre Figr. 1 (1. 3).

$$
\begin{aligned}
& , \quad \text { centre of ice-shodiline, 6.5. } \\
& ., \quad \text { described, }: 3 .
\end{aligned}
$$

Sturge Island, piedmonts, $6 \overline{7}$.

Suess, T. F.. tectonic processes, 122.

Sulphur, sulphur Cones, 12.

Sulphr1 Cones, basalts, 11, 12, 103-105, 11!, 120. . felspathic nodules in bisalt, $10 \%$.

Sultan's Ilead, tuffs and lasalts, 11, 109, 110.

Summary of Rejort on Field-creologr, $98,99$.

, of Report on Rock-specimens, 1:39, 1111.

Supraglacial matter, $7 \mathrm{~s}$

Sweet Grass Creck, diorite, anal., 12- .

Switzerland, gracicrs, 78 .

T, see Map and Tubular Mountain.

Tulble Mountain (E.), see Plate VII and Figs. 1 t (1. 29), $28(13.54)$.

Table of I istanes, 7 .

Tabular Mountain (T.), see Plate $\mathrm{V}, 70$.

Tabular Structure. Togal Socicty Range, 9s.

$$
\text { " Sonth Arm, } \quad \text { it (Fig. 28). }
$$$$
\text { Sece also IIorizontal Structure. }
$$

Talus-fans, from frost-action, 92.

Talus-slopes, Granite Itarbour, 83.

Temperature of ice, 8., 86, 99.

Tent Island, described, 16.

$$
\text { , kenstc, } 16,111 .
$$

Terra Cotta Mountains $\left(\mathbf{B}_{6}, \mathrm{~B}_{7}, \mathbf{B}_{3}\right)$, see Plate VII and Fig. $2: 3$ (p. 47 ).

Terra Nova (Alount), 8, 10.

Terror (Mount), sep Plate I and Fig. 5 (p. 10).

$$
\begin{aligned}
& \text {, } \quad 7,8,20,68,95,98 . \\
& \text {.. basalts, } 10,11,108-10.5,111 . \\
& \text {., boulder of calc-schist, } 124 \text {. } \\
& \text {, centre of ice-shedding, } 65 \text {. } \\
& \text {, describer, 10,11. } \\
& \text { " dolerite-bonlders, 11, 183. } \\
& \text { ". } \quad \text { rranitc-boulders, } 11,32,1 \geq 8 \text {. } \\
& \text {. moraines, } 81 \text {. } \\
& \text {, olivine-nodule, } 1118 . \\
& \text {., farisitic rents, } 11 . \\
& \text {, pressire-ridges, } 8: \text {. } \\
& \text { "Sindstone-honkers, } 11 . \\
& \text { " tide-cracks in birrier, } 67 . \\
& \text { " trachytes, 10, 114, 115, 1:0. } \\
& \text { I'late VIII, Fig. } 4 . \\
& \text { See also Crozicr (Cilje). }
\end{aligned}
$$

Thalury of glacions, 64, 73.

'T'hawing of seit-ice, 60 .

Thickness of sea-ive, 59 .

'Tide-crack, (i7, 7!), 8:3.

'litunic acid, liggli perecntage in basalts, 10:, 10.i, 110 . 
Tongarirn, 7.

'Tongue' of diorite, 127.

'Torriclon Sindstone, 5:3.

Traehydolerite, Campanario, anal., 119, 121. Inuceessible Island, 16 . of Rosenbuselı, $11:$.

Sto" also Kienyte and Traehyte (phonolitic).

Traeliyte (phonolitie), 102, 1 t0.

lilack Island, 1t, 115, 116, 123.

Brown Island, 15, $11 \%$. " anal., 115.

Cape Crozier, 11, 114, 115.

". anal., 114.

Crozier ('liffs, 10.

Eerteral, 11 s.

Furodada, 117-119.

.. anal., 119.

Inacessible Islind, 16, 114, 115.

Nount Terror, 11, 114, 11:, $1: 0$, and Plate VIII, Fig. $t$.

Obserfation Hill, 13, 117119, and Plate TIII, Fig. 6.

Razor Back Island, 16, 11.

.. Rivor bitek Istand, $\quad$ Scott Islands. 11 .

". $\quad$ anal., 114.

" wind-uficet on, $87,88$.

Traehytes (phonolitic), deseribel, 11:-119.

Transport of sen-iee, 59.

Treib-eis, 57 .

Triangle (Osamn), 121.

Tschermak, (r., Sierra de Chaeo Meteorite, ref., 169.

Tuckett, F. F., cavities in granites, ref., 89.

Tuffs, Cape Adare, $1 \stackrel{\text {. }}{ }$

,Cape Crozier, 10, 11, 109, 110.

" Castle Roek, 12, 109, 110.

". IIutton Cliffs, 11, 109, 110.

, Sknary, 9.

"Sultan's Head, 11, 1199, 110.

" Turk's IT ead, 9, 109.

"T-Cliffs Hogsluack, 10, 109, 110.

Turk's IIead, 11.

$$
\begin{aligned}
& \text { basalt-tuffs, 9, } 169 . \\
& \text { ice-streams, } 65 .
\end{aligned}
$$

Turtle Back Island, angite-olivine nodule, 14, 108 (Fig. 60).

basalt, 1 t, 106.
described, 1 t.

". kenyte, 14, 110 (Fig. 60), 111

(Fig. 68).

Tyndall, J., on glaciation, ref., 99.
Upper Trukri Hills, see Kinkri Hills.

Up-thrust of morainie material, 7 (i (lig. 41 ), s.2.

V-Cliffs IIogsback, basilt-tuffs, 10, 109, 110.

Valley-crlicicis, 6:, 71, 72 . bombs, 10 .

Variolitie structure in enntact-dolerite, 1:38.

Vasvik, rhomb-porphyry, anal., $11:$.

Vegetation in Antaretie regions, 1 .

Vein-quartz, probles in samlstone, 41.

Tesicular ice, fis.

Victoria Isand, see South Vietoria Land.

Tolcanic cones, Cape Mccormick, 19.

" mainland of Sontli Victoria Land, 1 i, 98.

Nount Firewster, 19.

Mount Miscovery, zo,

Mount Melbonrne, 19

.. Nount Norning, 20 .

Voleanic rocks, chemical relations of, 119-123.

., deseribed, 102-12:.

" two groups of, 121,122 .

Tolcino, active, Nount Erebis, 8.

Tolenoes, Auekland, 12. on Buekle Island, 1, 3.

Wadworth (Cape), 5, 6.

$$
, \quad \text { trachyte from dledge, } 115 .
$$

Waltershausen, S. W. ron, Monnt Etna, ref., 9.

Walther, J., desert-meathering, ref., 87.

$$
, \quad \text { weathering of granite, ref., } 38 .
$$

Waslington (Cape), 20-22.

Washington, H. S., bibliography of lornblende psendomorphs, ref., 103.

elassification of rocks, ref., 120 .

TVater-action, 89-91, 99.

in moraines, s? (Fig. 52).

Water-tomses, Maequarie Islant, 96.

Water-holes, 58 (Fig. 82), 59.

Weathering, of granite, 83.

$$
\text { " of trachytes, } 118,117 .
$$

Weller (A. B.), to.

West Fort $\left(\mathrm{C}_{9}\right), 50$.

West Groin, lonbtful fossils, 4: (Fig. 21), 4 .

,$\quad$ jipe of dulerite, 50.

. sandstone and dolerite, $42-44$.

Wester"n Mountains, see Royal Society Raurge.

White Island, see Fig. 32 (1. 5s).

$$
\text { basalt, } 15,104 \text {. }
$$


White Istand, deseribed, 14.

, grabbro ill inoraines, 139.

.. Glauber Silt, 91.

.. moraines, $79,80,91$.

.. pressure-ridges, 8.2.

.. tide-eracks in barrier, $67,8 \%$,

. resieular ice, 6s.

Whitner, J. 1)., on glaeliation, ref., 99.

Williamson Point, basilt, 109.

Wilson, 1)r. E. A., basalts from Monnt Terror, 10.

.. Glauber Salt, 91.

.. observations on Mount Erebuss,9.

. rocks from near Koettlitz Glacier, 26, 129.

roek-specimens from Diseorery Gulf, 1:21.

skivete

Wind-activil, $87,88,99$.
.,$\quad$ on sandstone, 92

$" \quad$ remoring snow, 84.

Win l-worn stones, Winter Quarters, 87.

Windy Gnlly, see Plate VII, 69, 70.

Winter Harbour, glacier-iee fringe, 62.

Winter Qnarters, sfe Plate II. and Figs. 32 (p. 58), and $3: 3$ (p. 59$)$.

, $\quad 8,14,16,19,29,82,92,98$.

.. basilts, $11-18,104,105,111,128$.
Winter Quillters, boulders, 87 .

$$
\begin{array}{ll}
. & \text { denudation, } 87 . \\
. & \text { deseribed, 11-14. } \\
" . & \text { nodules in basalts, 106-109. } \\
. & \text { snow-drifts, } 84 .
\end{array}
$$

Winter Quarters Peninsula, glacier-iee fringe, 62.

$$
, \quad, \quad \text { hummoeks in sea-iee, }
$$$$
59 .
$$

Wolff, F. von, refraetion of anorthoclase, ref., 211.

Wollastonite in sandstone, 41.

Wood Bay, see Fig. 37 (p. 65).

$" \quad$ ice-foot, 65 .

, pumice, $20,93$.

.. stranded moraines, 81 .

Wyoming, banakite, 129.

$x$ (hill), see Map and Plate V.

" dolerite and sandstone, 46,51 .

, gullies, 92.

Young Island, deseribed, 1, 2.

Zireon, in granite, 126.

, in sandstone, 131.

Zirkel, F., felspathic nodules in basalts, ref., $10 \pi$.

$" \quad$ origin of olivine-nodules, 109.

'Zone of fire,' comnceting New Zealand and Mount Ereluns, 95 . 


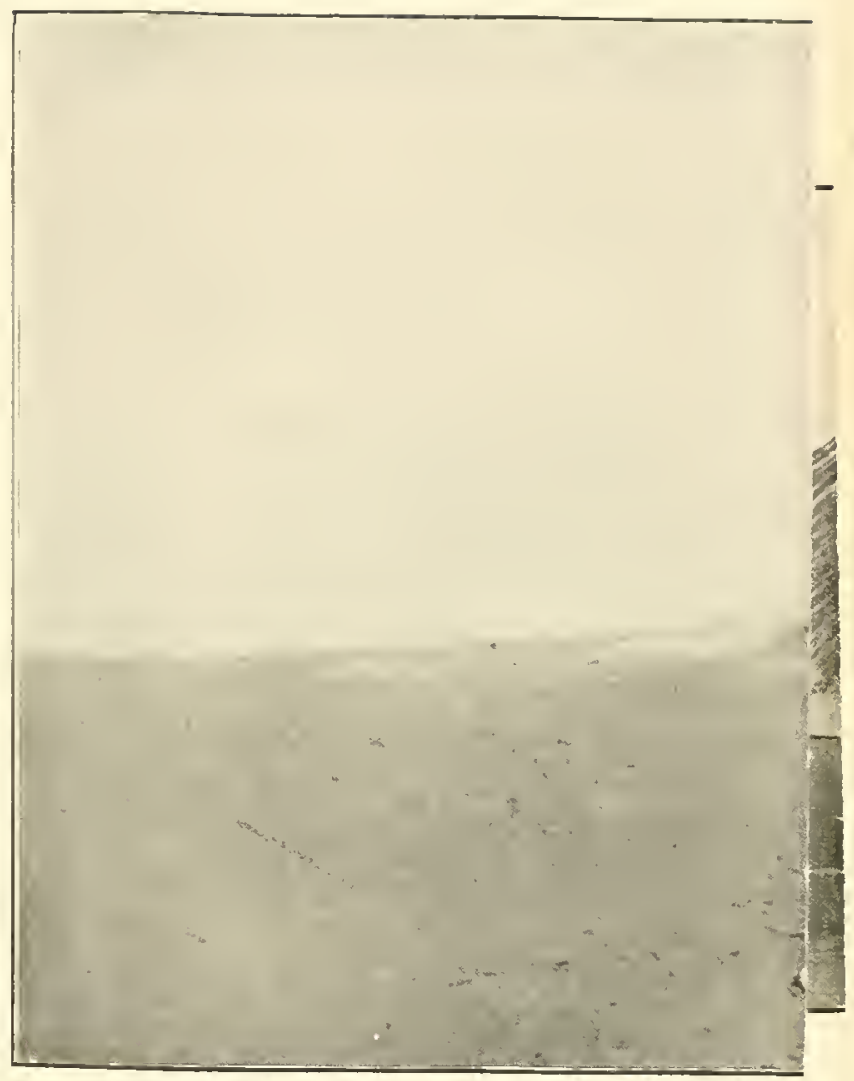

National Antarctic Expedition, 1901-1904. British Museum 




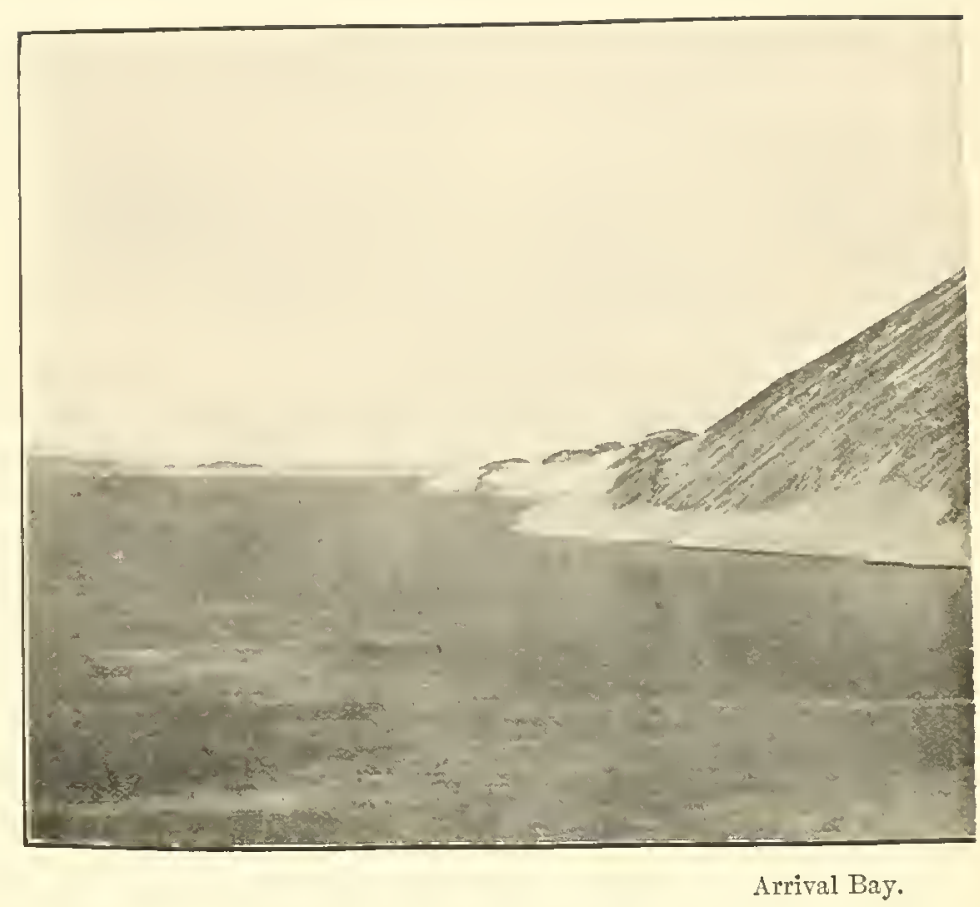

National Antaretic Expedition, 1901-1904. British Museum Report. Fiè 



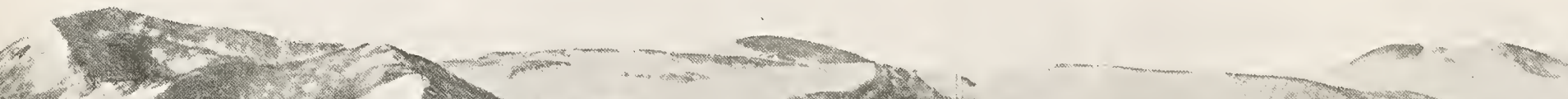

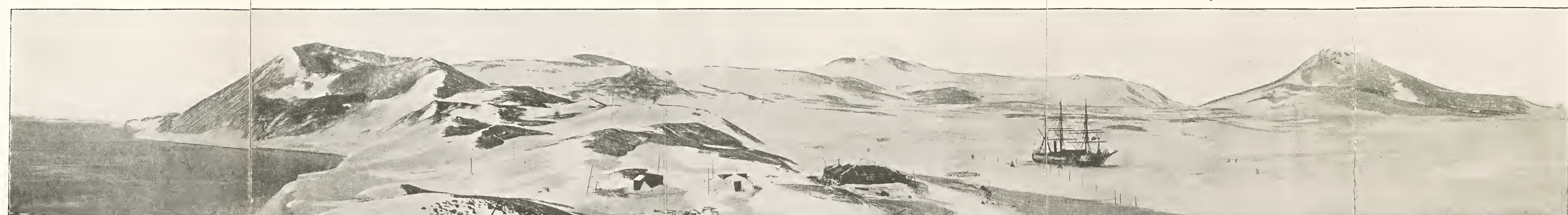

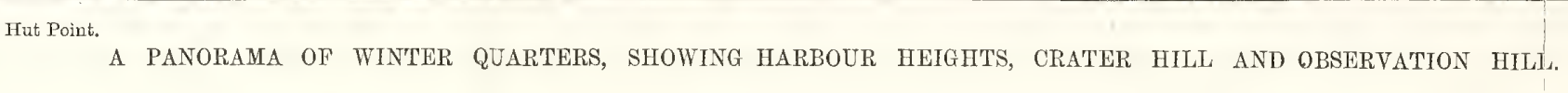




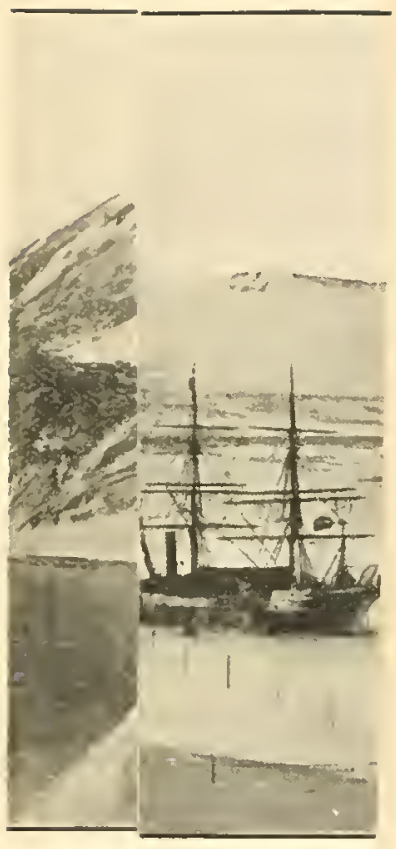

d-geology. ' 
Plate III.

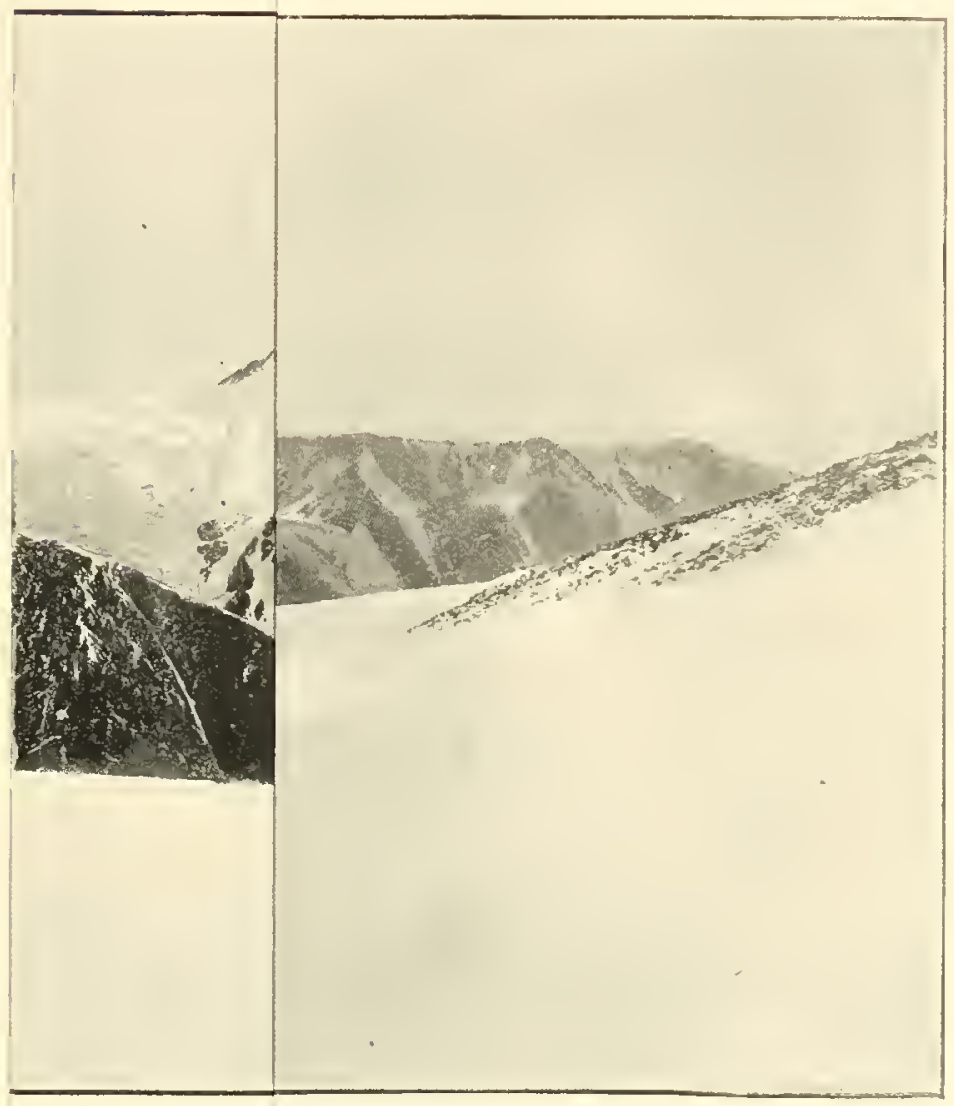

THE ROYAL S

Looking up Ferry 



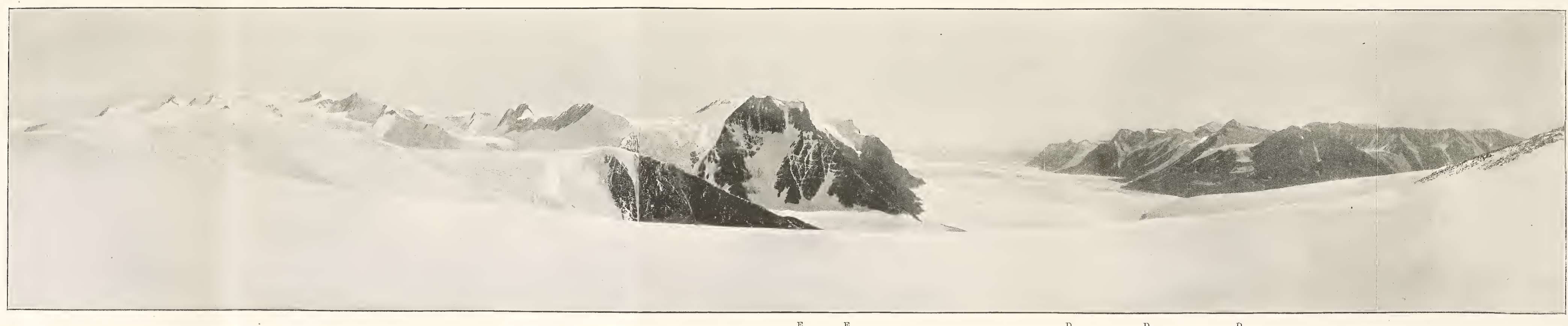

Royal Socioty Rauga

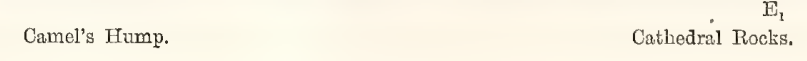

$\underset{\text { Ferara Ghacior }}{\mathrm{D}_{2}}$ Kukri Hills. 


\section{Plate IV.}

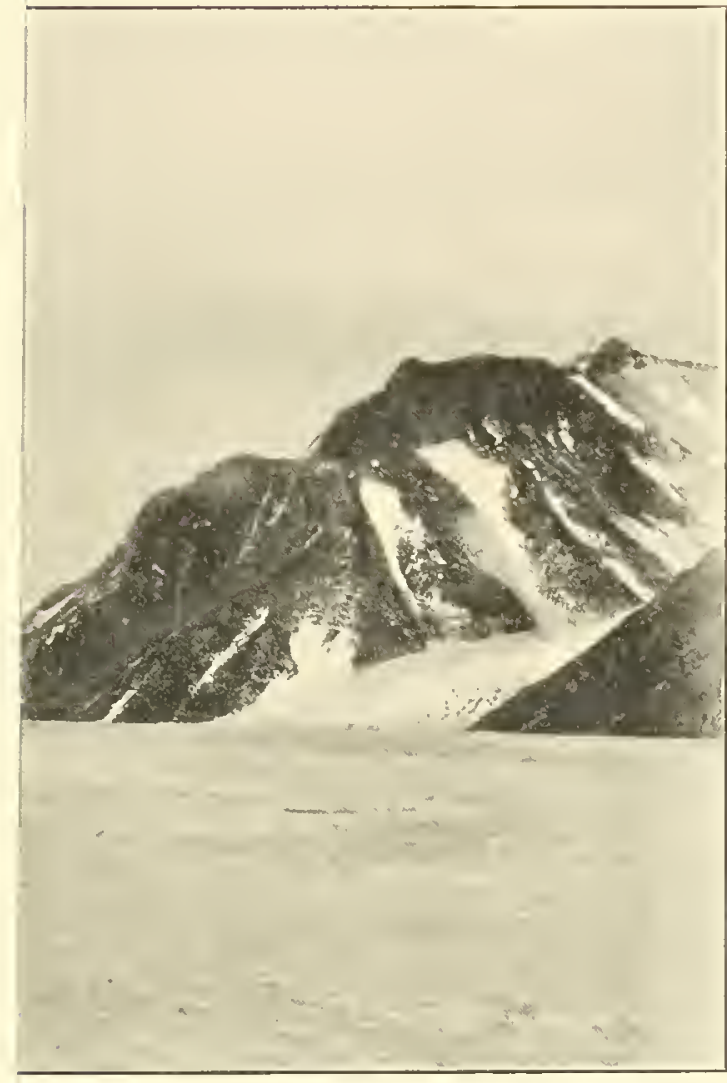

Greiss

shoulder.

$\mathrm{E}_{1}$

Cathedral Rocks.

$27,30,34$. 



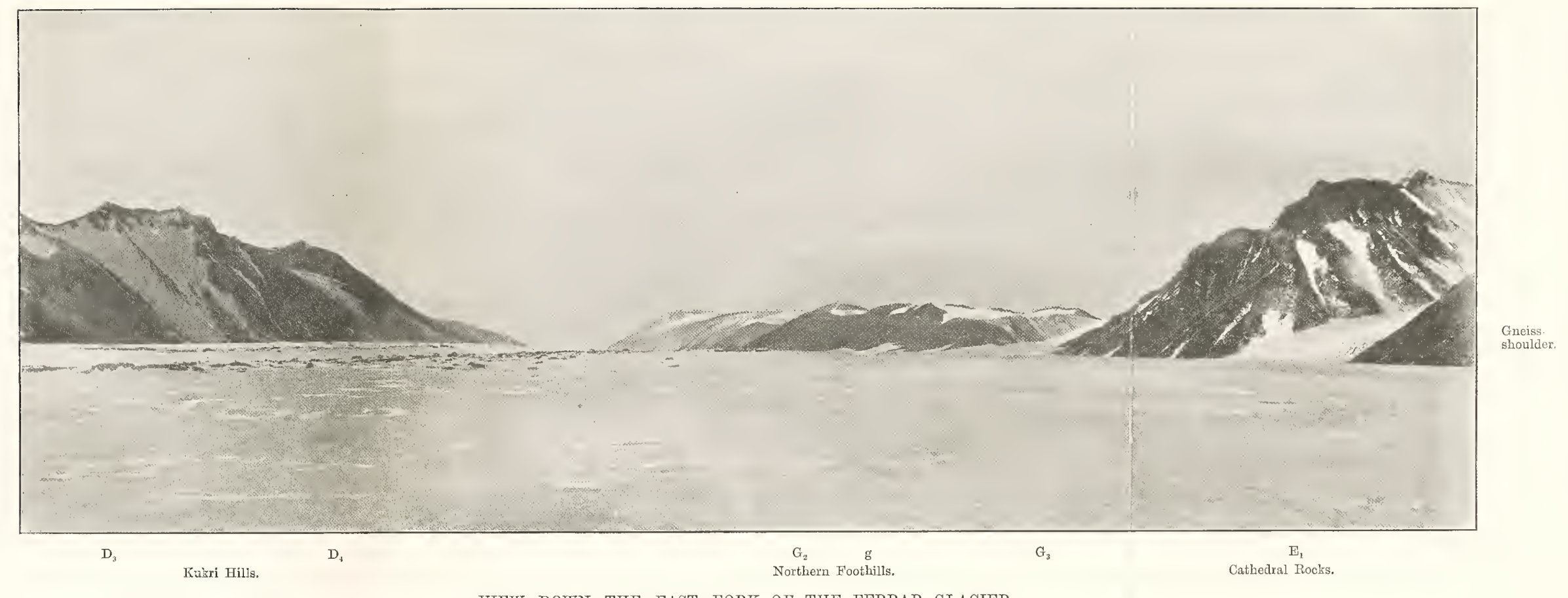

Showing the low granite-hills between $G_{2}$ and $G_{3}$ and the gneiss-exposure at the foot of Cathedral Rocks. See pp. 27, 30,34.

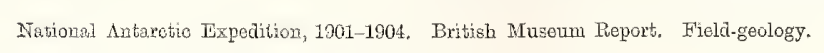


Plate V.

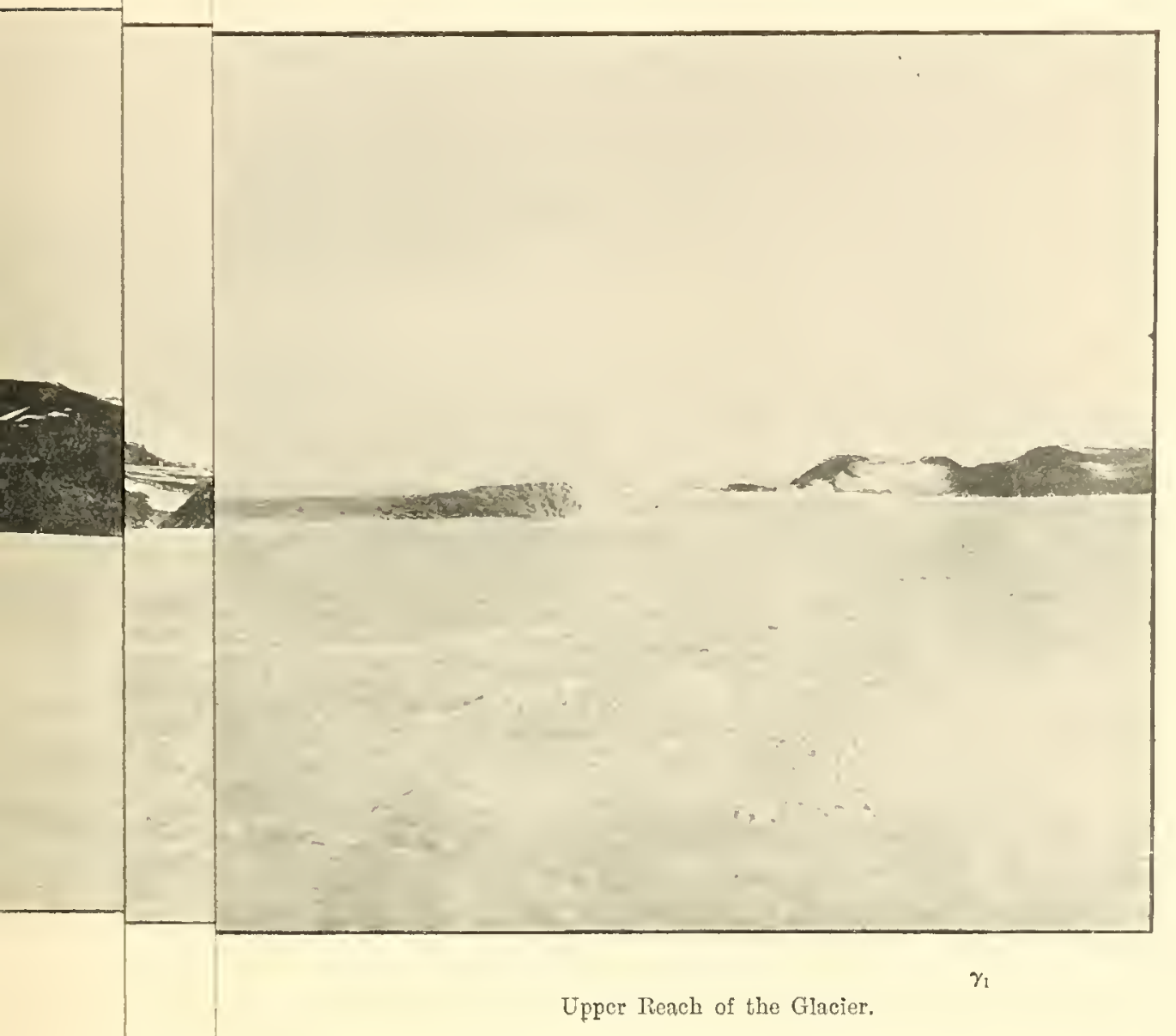

$45-47$ 



\section{n.}




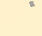

- 


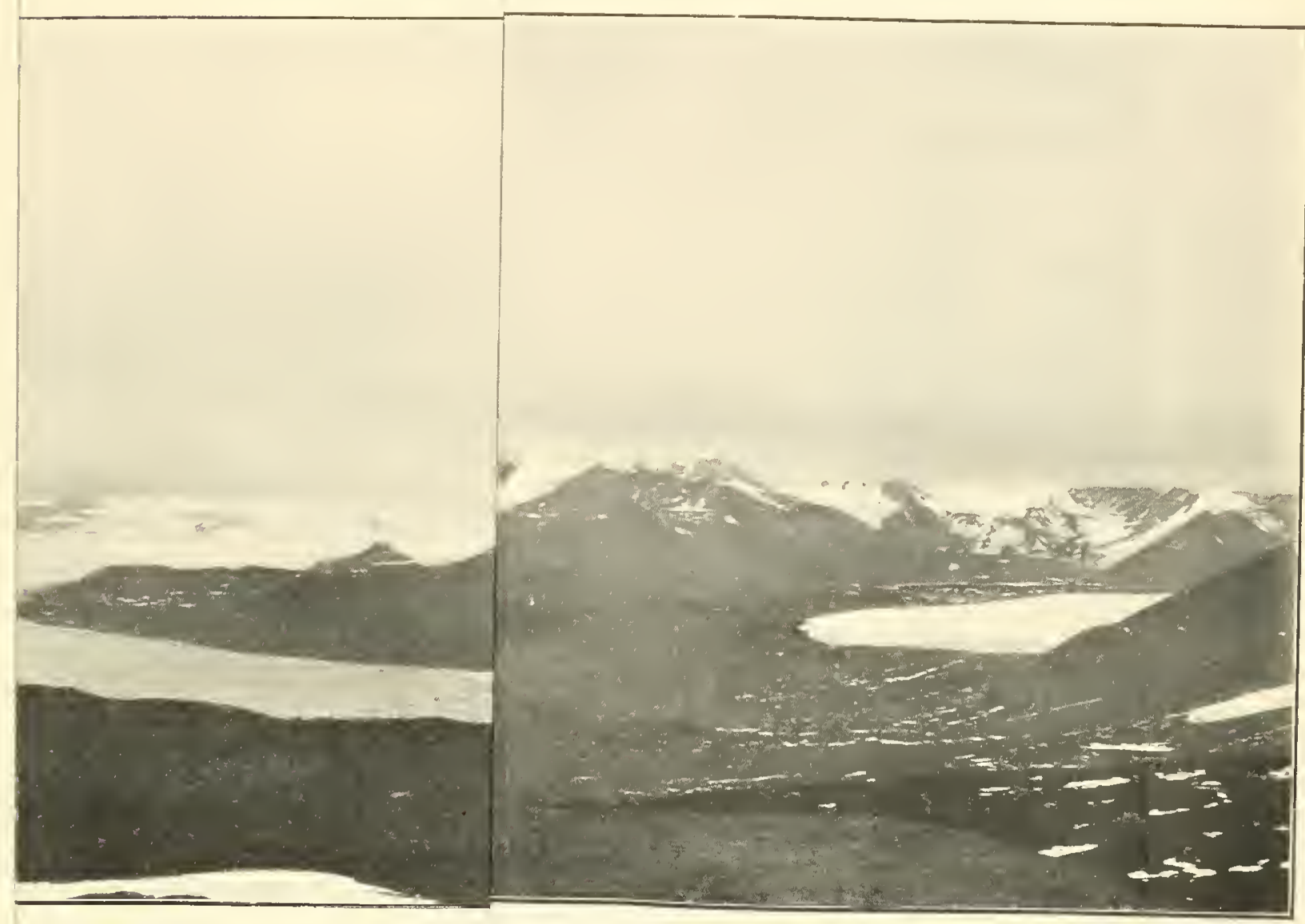

The Ends of Ice-slabs.

TO A TRIBUTARY VALLEY CON 



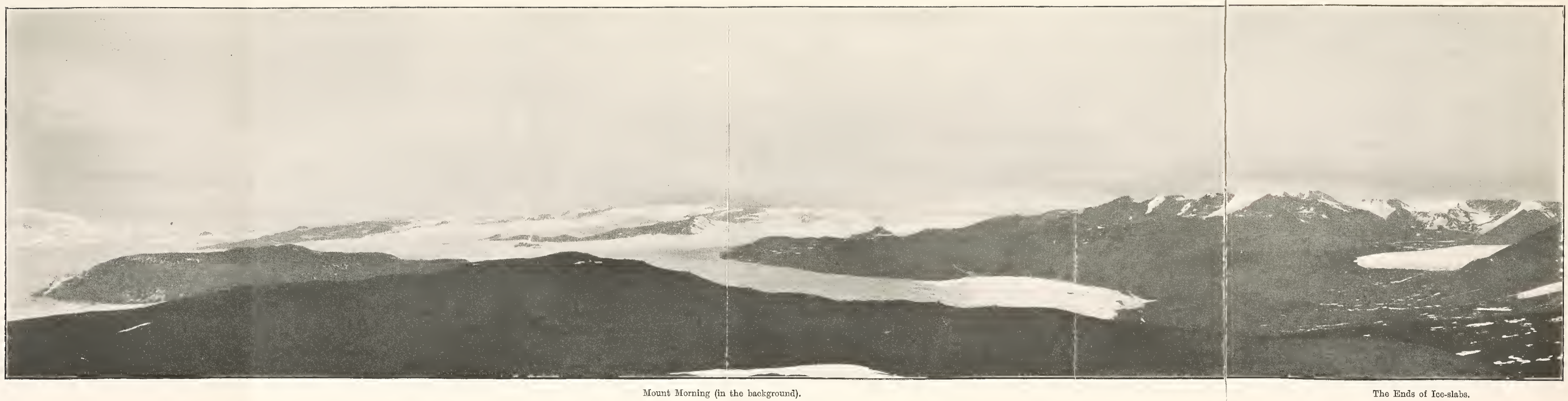

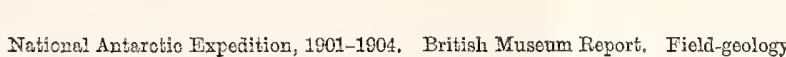

THE OVERFLOW OF THE KOETTLITZ GLACIER INTO A TRIBUTARY VALLEY CONTAINING AN ICE-SLAB, See pp. $71,73$. 
Plate VII.

DEPOTT NUNATAK

SOUTH-WEST ARM

$\mathrm{B}_{1}$ (fossil plant-remains.)

TE
A $\left(7,650 f^{\circ}\right)$

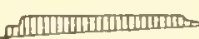

INLAND-ICE

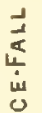





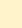





\section{EXPLANATION OF PLATE VIII.}

Fir. 1.-Olirine-basalt (656) from cliff between Gap and Horseshoe I3ay (p. 104).

All the clear olivines, cxeept the three crystals at the top, belong to one individnal : the more shaded crystals are augite.

Magnification, 30 diam., 1 ineh objective.

Fug. 2.-Gabbro-like nodule (415) in limburgite, from Winter Quarters (p. 108).

The dark grains are altcred olivine, the shaded grains arc pale-green diopside, a rather morc deeplyshaded grain on the left below is hornblende, the clear crystals showing twin-striations are felspar.

Nagnification, 30 diam., 1 inch objcetive.

FIfr. 3.-Leneite-kenyte (81s) from Cape Royds (p. 111).

The large phenoeryst of anorthoelase shows crossed twin-striations as seen between crossed nicols: numerous small leueites with central inclusions are secn in the base; on the left towards the bottom is a small phenocryst of olivine.

Magnifieation, 20 diam., $1 \frac{1}{2}$ inch objective.

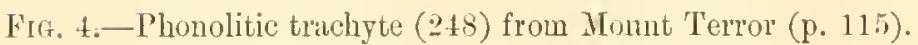

A rectangular phenocryst of anorthoelase is seen in a trachytic mesh of felspar-laths with dirk grains of xgirine-angite.

Magnification, 30) diam., 1 inch oljjectire.

FIG. 5. - Phonolite (580) from Blaek Island (1. 116).

Hornblende near to ricbeckite, in moss-like patches, in finc-grainct trachytie felt of felspar-lathls.

Magnification, 30 diam., 1 inch objectire.

FIG. 6.-Plionolitic hormblende-trachyte (27) from Obserration Hill (1. 117).

I'rismatic crystals of basaltic hornblende in trachytic mesh of fclspar-laths.

Magnification, 30 diam., 1 inch objective. 

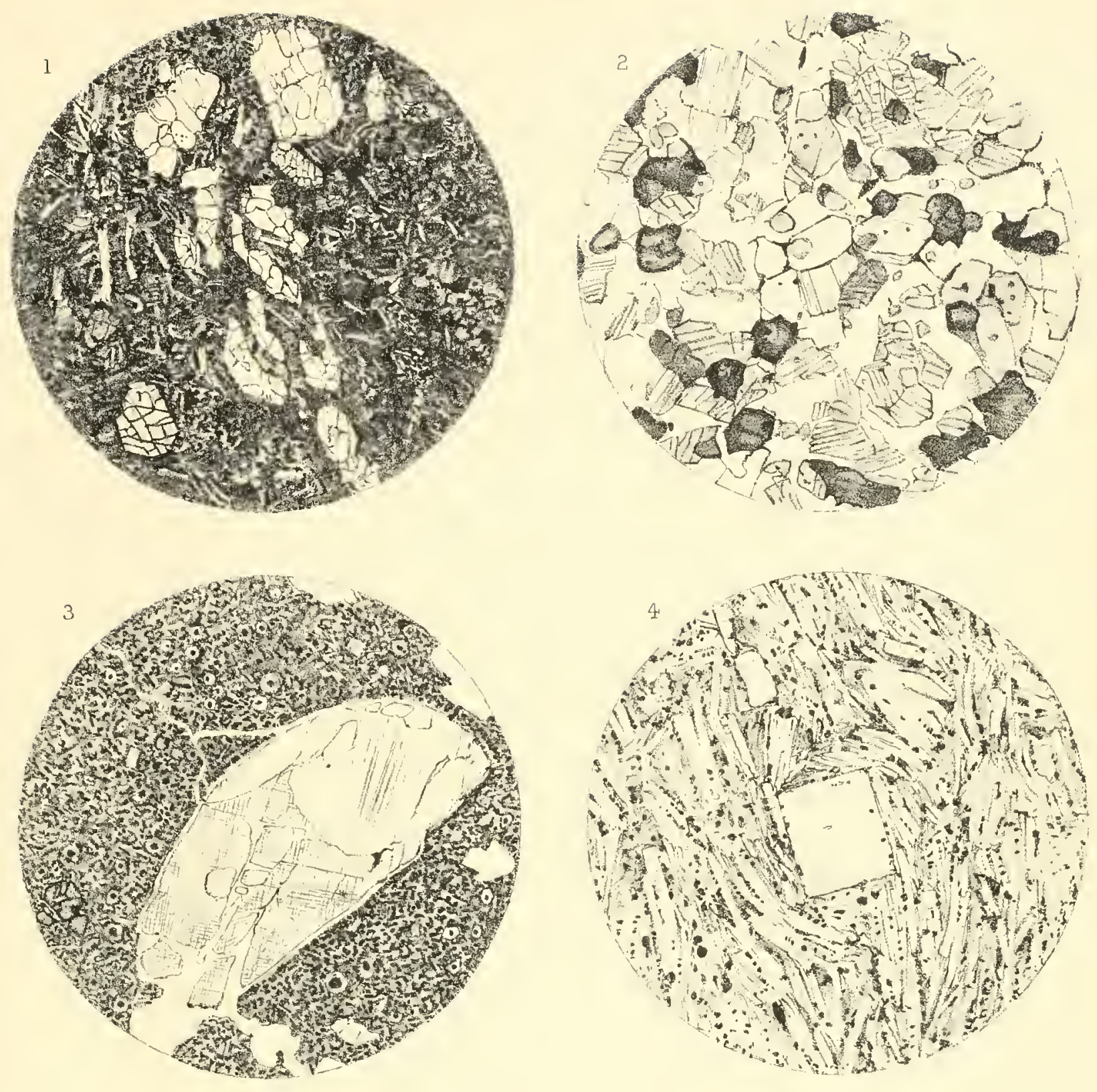

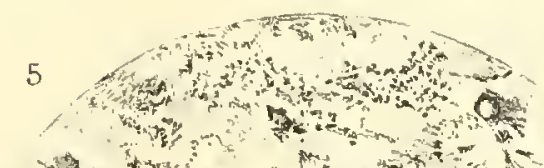

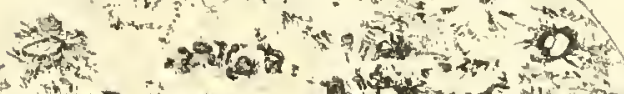

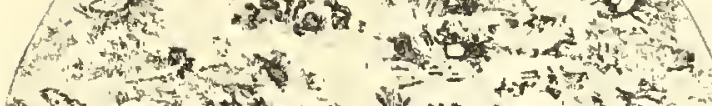
a d

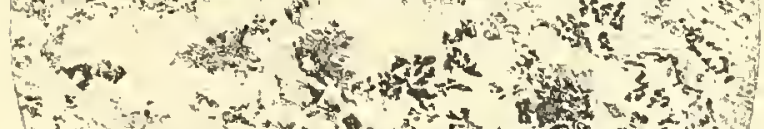
(3)$$
\begin{gathered}
4 \\
4 \\
4
\end{gathered}
$$

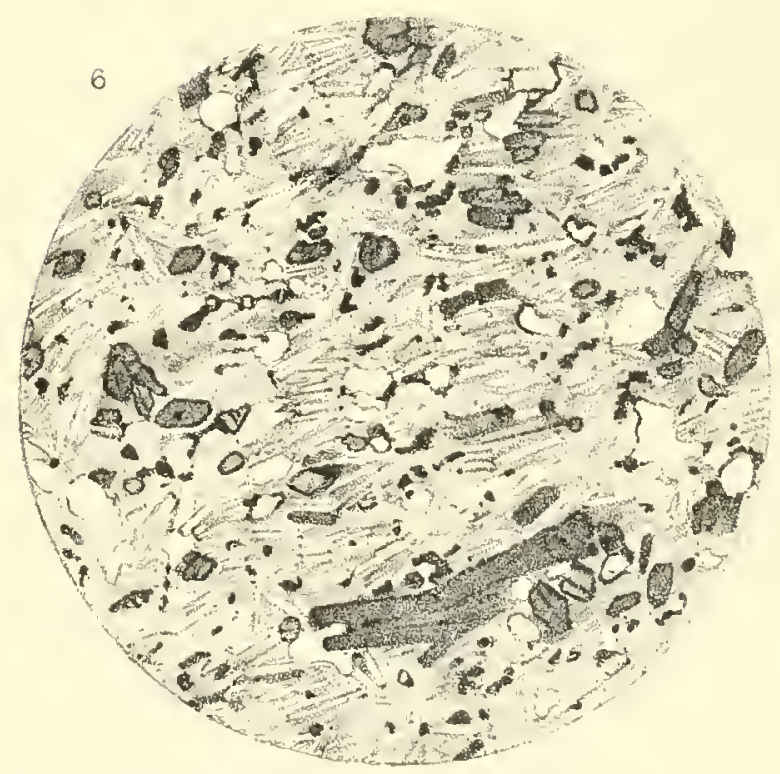





\section{EXPLANATION OF PLATE IX.}

FIt. 1.-Angen-gneiss below 1), Kukri Hills (p. 125).

Cataclistic strncture as seen between crossed nicols.

Nagnification, :0 diam., 1. ineh objective.

Fig. ․--Diorite (715) from Cathedral Rocks (p. 127).

Large ophitic plates of brown hornblende, and labradorite.

Magnifieation, 이 diam., $1 \frac{1}{2}$ ineh objeetive.

FIf. 3.-Diorite to essexite (5:2) from the Blue Glacier (1. 126).

Large sharply-defined erystals of brown hornblende with altered felspars, and mnch apatite in small hexagonal seetions.

Magnifieation, 20 diam., $1 \frac{1}{2}$ ineh objective.

F[1. 4.-Kersantite (5:3) from Northern Foothills (p. 1:31).

Biotite (dark, straggling erystals) and nearly colourless diopside (irregnlar, shaded plates) in a base of katinised felspar-laths.

Magnifieation, o diam., $1 \frac{1}{2}$-ineh objeetive.

F'tr. 5.-Camptonite (839) from Sonthern Foothills (1) 129).

Small, sharply-defined, erystals of reddish-brown hornblende in a base of felspar-laths.

Magnifieation, 20 diam., 1 -inch objeetive.

Fic: (1.-Dyke-rock (j1t) related to banakite, from the Northem Foothills (p. 1:31).

Phenoerysts of litbradorite (in eentre), orthoelase (below, to the left), brown hornblende (below, to right), amaleite (round seetion, below the labradorite to the right), and purplish angite (abore the labralorite to the left), in it base of reetungular and lath-shaped felspars.

Magnification, 20 dian., $1 \frac{1}{2}$-inch objeetive. 

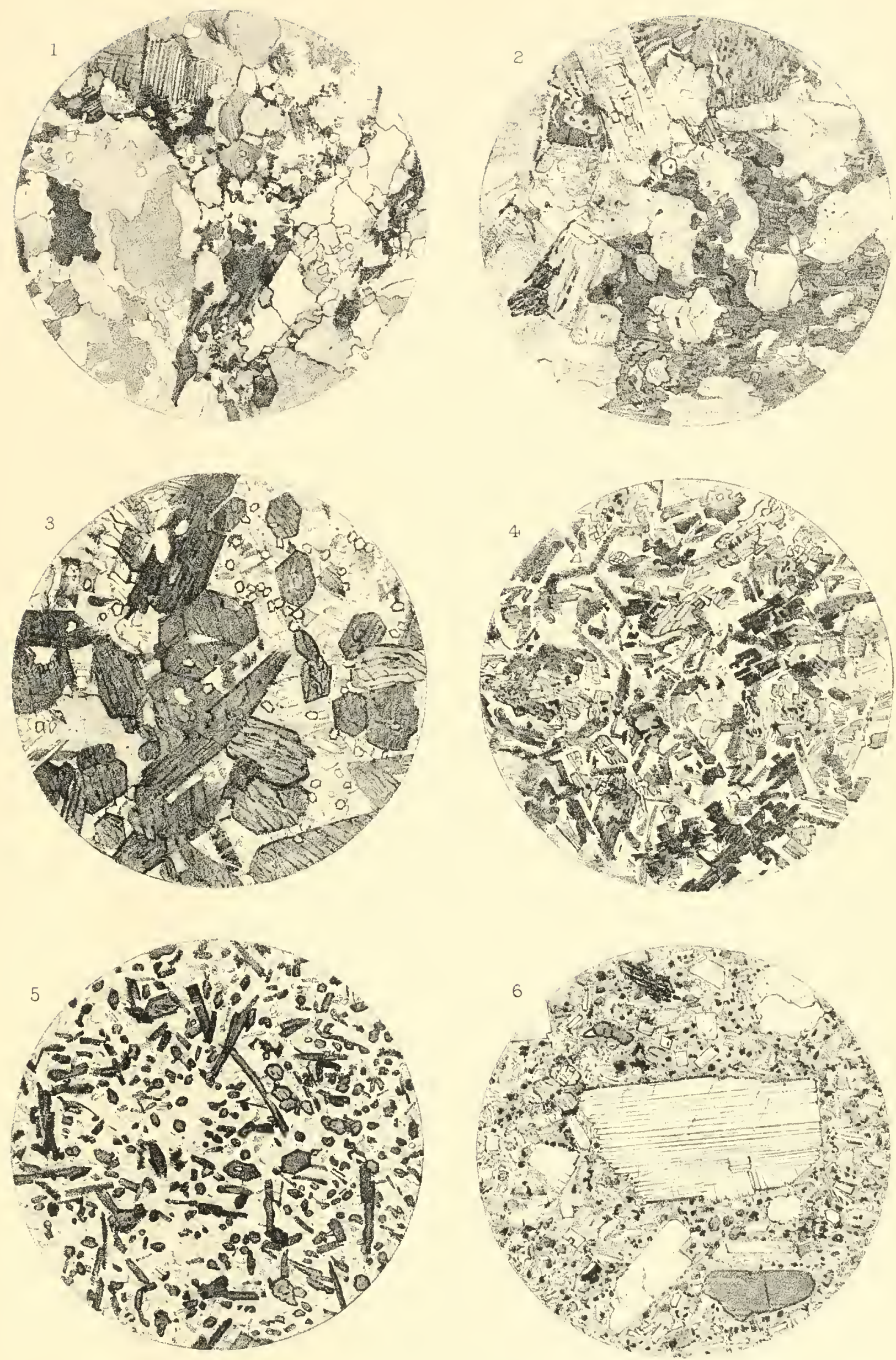




\section{EXPLANATION OF PLATE X.}

FIr. 1.-Dolerite (662) from Depôt Nunatak (p. 136).

The shaded crystals are of augite; some of the darker ones are altered aud coloured brown with oxide of iron. 'The clenr sections are of labradorite. On the left and in the interstices of the felspars and augites are seen patches of spherulitic material.

Magnification, 20 diam., $1 \frac{1}{2}$-inch objective.

Frr.z.-Dolerite (696), 2 ft. from junction with sandstone, Dry Valleys (p. 13x).

The angite is mainly in long prismatie crystals, the felspars in small laths: interstitial felsitic naterial is crowded with magnetite.

Magnification, : $:$ diam.. 1-inch objective.

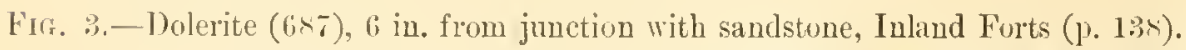

lougr prismatic felspars and angites, and interstitial glass black with magnetite.

Magnification, 80 diam., 1-ineh objective.

Fir. 4.-Dolerite (695), 2 in. from junction with sandstone, Dry Valleys (p. 1:38).

Radiating sheares of felspar-laths, and interstitial glass deuse witl magnetite; a few porphyritit felspars.

Magnification, 30 diam., 1-inclı objective.

Fir. 5.-. Junction of dolerite and sandstone (1699) at $B_{1}$ (p. 198).

Brown glass, with dark, cloudy patches; a few porphyritic felspars.

Magnification, „20 diam., $1 \frac{1}{2}$-inch oljectire.

FFเ. 6.-Dolerite (15t) with granitic patches. Granite Harbour (p. 189).

wolerite of purplish augites, felspar-laths and magnetite, witl coarse-grained patch of altererl felspars and quartz.

Magnification, 30 diam., 1-inch objeetive. 

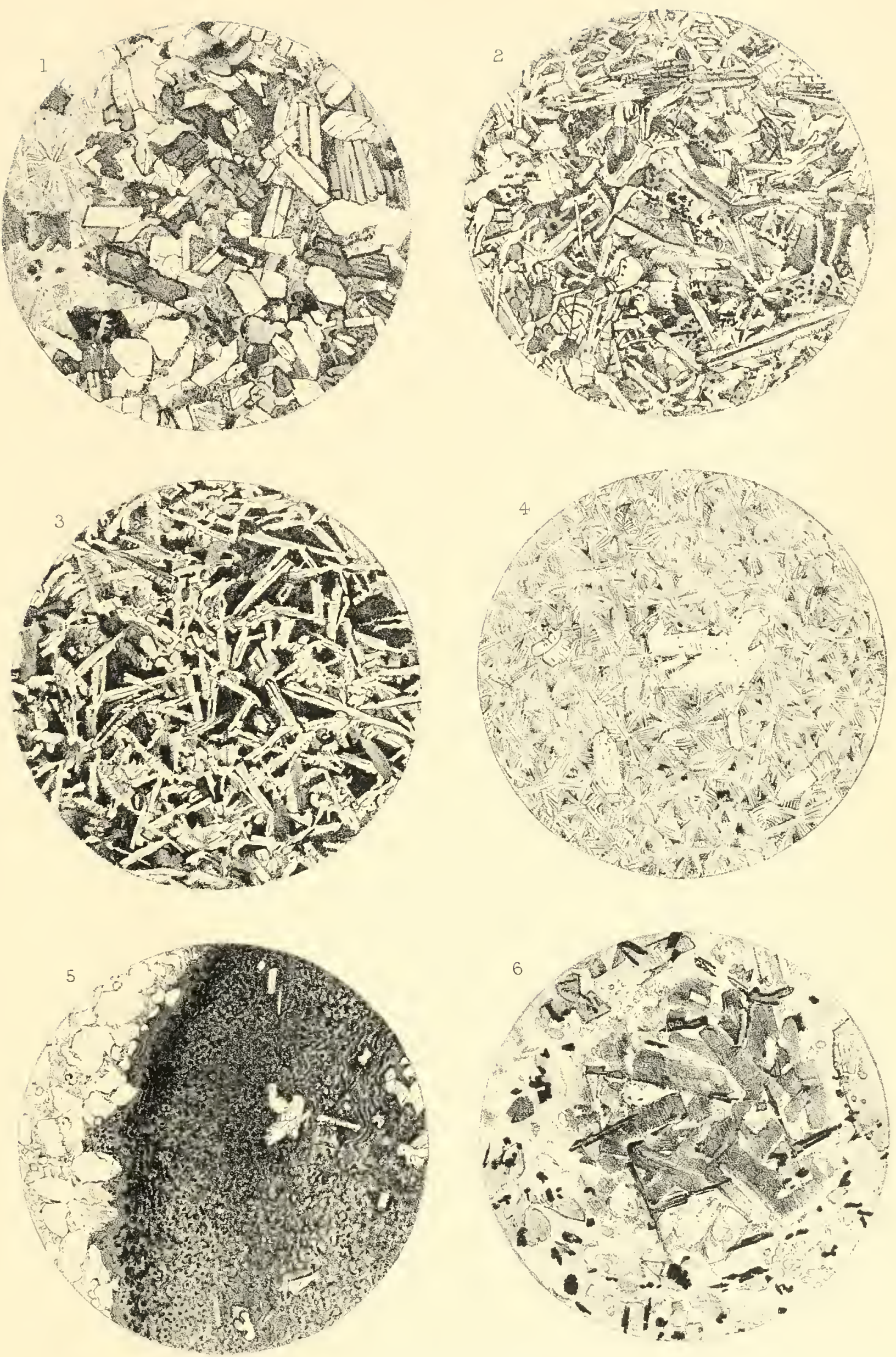

ROCK-SPECIMENS.

F. Drake del et lith.

National Antarctic Expedition, 1901-1904. 





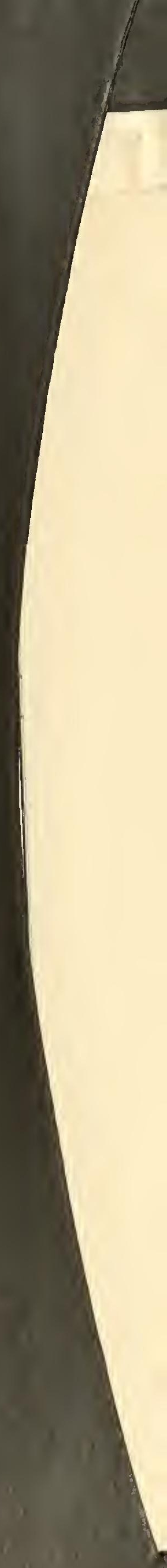





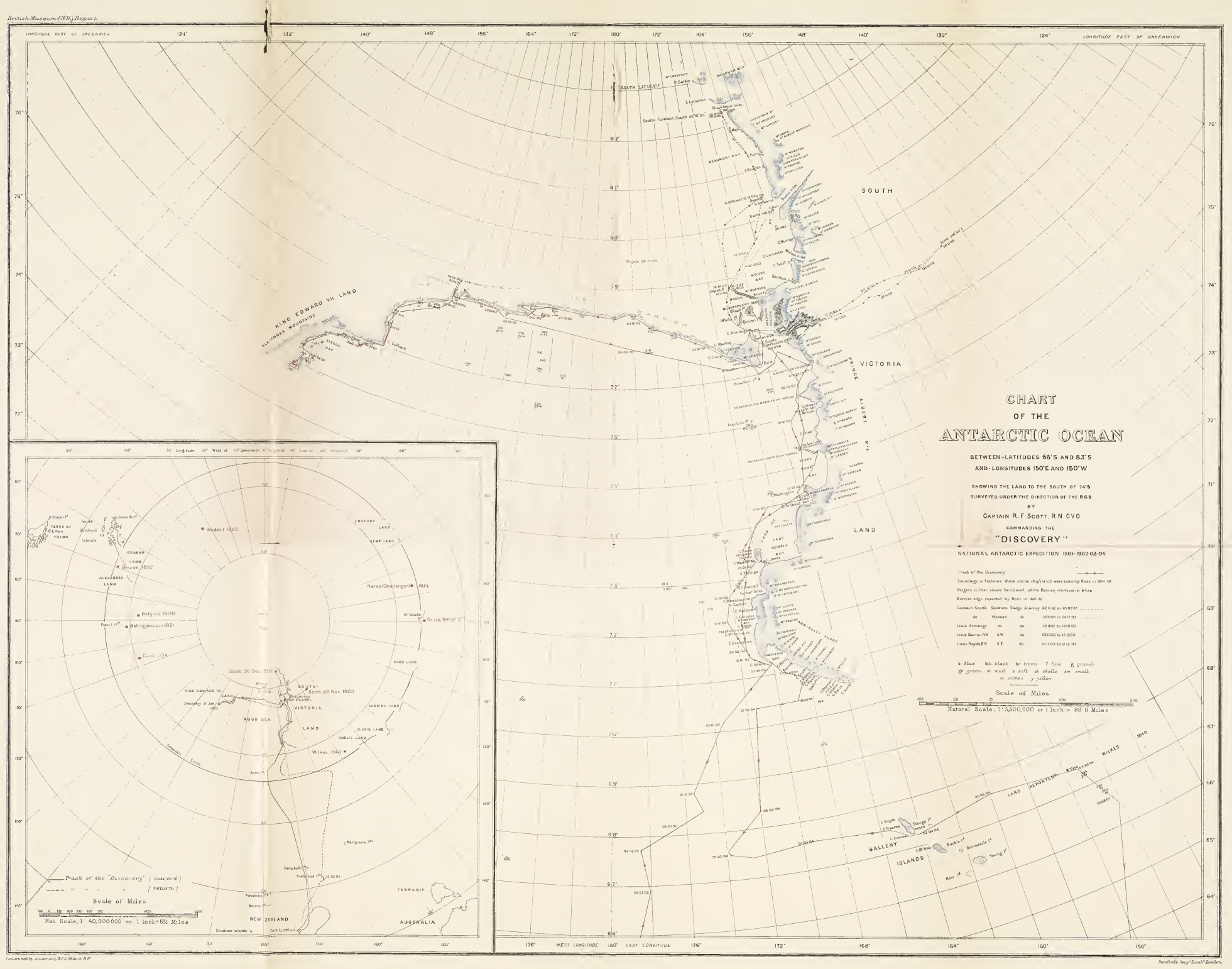





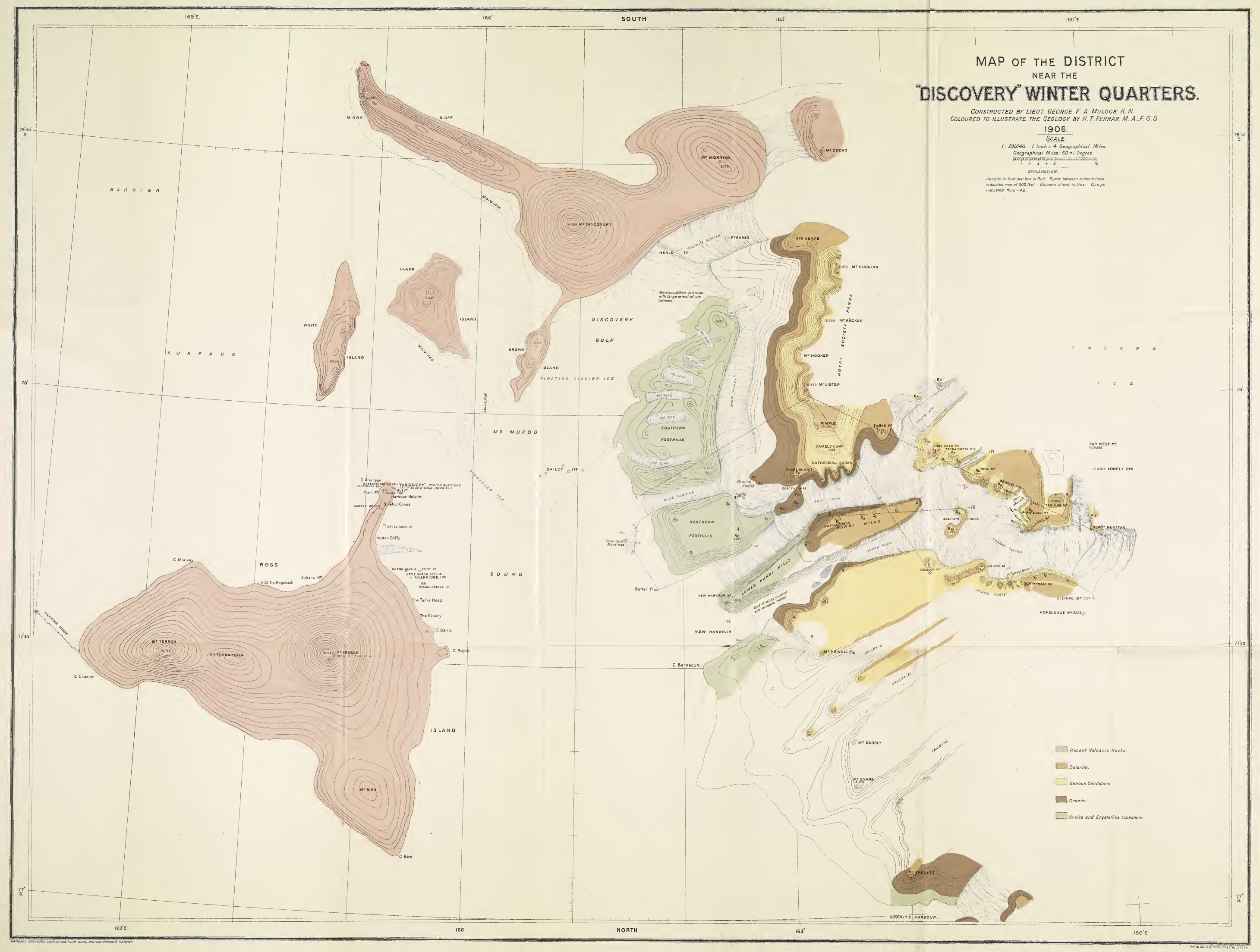


